\title{
MONOGRAPH
}

\section{SCIENTIFIC APPROACHES IN JURISPRUDENCE}


ISBN - 978-1-64945-861-2

DOI- 10.46299/ISG.2020.MONO.LEGAL.III

Ocientific approaches in

juxisprudence

Gollective monograph

Boston 2020 
Library of Congress Cataloging-in-Publication Data

ISBN - 978-1-64945-861-2

DOI- 10.46299/ISG.2020.MONO.LEGAL.III

Authors - Lohvinenko M., Kordunian I., Петровська I., Шевченко Н., Мезеря О., Ярошевська Т., Пересада О., Ральченко I., Хоббі Ю., Шереметьєва О., Naumova K., Belkin L., Iurinets J., Belkin M., Chernyk Y., Бліхар M., Горяінова Н., Видиборець С., Хоменко I., Михайличенко Б., Rudanetska O., Berezhnytska H., Cherviakova O., Shchokin Y., Roianova I., Сироїд T., Гавриленко O., Шамраєва В., Фоміна Л., Тітов С., Kolobov L., Karpova N., Verhun I., Melnyk R., Pylypenko Y., Pestsov R., Камінська О., Маркевич О., Муляр В.

Published by Primedia eLaunch https://primediaelaunch.com/

Text Copyright (C) 2020 by the International Science Group(isg-konf.com) and authors. Illustrations (C) 2020 by the International Science Group and authors.

Cover design: International Science Group(isg-konf.com). (C)

Cover art: International Science Group(isg-konf.com). (C)

All rights reserved. Printed in the United States of America. No part of this publication may be reproduced, distributed, or transmitted, in any form or by any means, or stored in a data base or retrieval system, without the prior written permission of the publisher. The content and reliability of the articles are the responsibility of the authors. When using and borrowing materials reference to the publication is required.

Collection of scientific articles published is the scientific and practical publication, which contains scientific articles of students, graduate students, Candidates and Doctors of Sciences, research workers and practitioners from Europe and Ukraine. The articles contain the study, reflecting the processes and changes in the structure of modern science.

The recommended citation for this publication is:

Scientific approaches in jurisprudence: collective monograph / Lohvinenko M., Kordunian I., - etc. - International Science Group. - Boston : Primedia eLaunch, 2020. 213 p. Available at : DOI- 10.46299/ISG.2020.MONO.LEGAL.III 
TABLE OF CONTENTS

\begin{tabular}{|c|c|c|}
\hline 1. & ADMINISTRATIVE LAW & 6 \\
\hline 1.1 & $\begin{array}{l}\text { Lohvinenko M., Kordunian I. } \\
\text { HOW THE PROFESSIONAL AND COMMUNICATION } \\
\text { SKILLS OF A MEDIATOR AFFECT THE OUTCOME OF } \\
\text { MEDIATION? }\end{array}$ & 6 \\
\hline 1.2 & $\begin{array}{l}\text { Петровська Ірина } \\
\text { ПУБЛІЧНЕ АДМІНІСТРУВАННЯ ФУНКЦІОНУВАННЯ } \\
\text { ВІЛЬНИХ ЕКОНОМІЧНИХ ЗОН В УКРАЇНІ: ПИТАННЯ } \\
\text { ВДОСКОНАЛЕННЯ }\end{array}$ & 12 \\
\hline 1.3 & $\begin{array}{l}\text { Шевченко Н. Л. } \\
\text { АНАЛІЗ ВІТЧИЗНЯНОГО ТА ЗАРУБІЖНОГО } \\
\text { ЗАКОНОДАВСТВА ЩОДО ДОТРИМАННЯ ПРАВ } \\
\text { ЛЮДИНИ } \\
\text { УКРАІІНИ }\end{array}$ & 19 \\
\hline 2. & BANKING LAW & 24 \\
\hline 2.1 & $\begin{array}{l}\text { Мезеря О. } \\
\text { СУБ’ЄКТ КОНТРОЛЮ ЗА ДІЯЛЬНІСТЮ БАНКІВ В } \\
\text { УКРАЇНІ. ДІЯЛЬНІСТЬ ФОНДУ ГАРАНТУВАННЯ } \\
\text { ВКЛАДІВ ФІЗИЧНИХ ОСІБ }\end{array}$ & 24 \\
\hline 3. & CIVIL LAW & 33 \\
\hline 3.1 & $\begin{array}{l}\text { ЯрошеВсьКа Т.В. } \\
\text { СТАНОВЛЕННЯ ТА РОЗВИТОК В УКРАЇНІ СИСТЕМИ } \\
\text { ПРАВОВОЇ ОХОРОНИ ПРОМИСЛОВОЇ ВЛАСНОСТІ }\end{array}$ & 33 \\
\hline 4. & CRIMINAL AND CRIMINAL - EXECUTI & 41 \\
\hline 4.1 & $\begin{array}{l}\text { Пересада О. } \\
\text { ПОПЕРЕДЖЕННЯ } \\
\text { ЗАВДАННЯ СУЧАСНОГО КРИМІНАЛЬНОГО ПРАВА }\end{array}$ & 41 \\
\hline 4.2 & $\begin{array}{l}\text { Ральченко І.М. } \\
\text { НАПАД ЯК ФОРМА ВЧИНЕННЯ ЗЛОЧИНІВ ПРОТИ } \\
\text { ОСІБ ТА УСТАНОВ, ЩО МАЮТЬ МІЖНАРОДНИЙ } \\
\text { ЗАХИСТ (СТ. } 444 \text { КК УКРАЇНИ) }\end{array}$ & 46 \\
\hline 5. & & 51 \\
\hline 5.1 & $\begin{array}{l}\text { Хоббі Ю. } \\
\text { ЄВРОПЕЙСЬКІ } \\
\text { ЛЮДИНИ }\end{array}$ & 51 \\
\hline
\end{tabular}




\begin{tabular}{|c|c|c|}
\hline 6. & FINANCE LAW & 59 \\
\hline 6.1 & 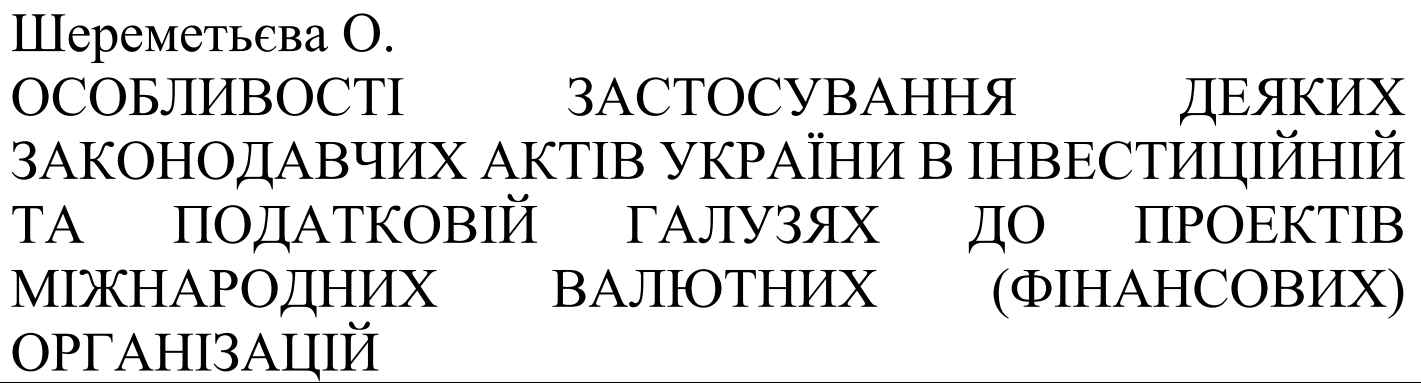 & 59 \\
\hline 7. & $\begin{array}{l}\text { HISTORY AND PROSPECTS OF DEVELOPMENT OF } \\
\text { LOCAL SELF-GOVERNMENT }\end{array}$ & 67 \\
\hline 7.1 & $\begin{array}{l}\text { Naumova K. } \\
\text { DIRECTIONS OF IMPROVEMENT OF THE LEGAL } \\
\text { REGULATION OF THE SYSTEM OF REGULATIONS OF } \\
\text { LOCAL SELF-GOVERNING AUTHORITIES AND } \\
\text { OFFICIALS IN UKRAINE AT THE PRESENT STAGE }\end{array}$ & 67 \\
\hline 8. & INFORMATION TECHNOLOGY AND LAW & 76 \\
\hline 8.1 & $\begin{array}{l}\text { Belkin L., Iurinets J., Belkin M., Chernyk Y. } \\
\text { CURRENT ISSUES OF INFORMATION SECURITY OF } \\
\text { THE STATE: THE UKRAINIAN MEASUREMENT }\end{array}$ & 76 \\
\hline 9. & INTERNATIONAL ECONOMIC LAW & 86 \\
\hline 9.1 & $\begin{array}{l}\text { БЛіХар М.М. } \\
\text { ДОКТРИНАЛЬНІ ПІДХОДИ ЩОДО СУТНОСТЕЙ ТА } \\
\text { ОСОБЛИВОСТЕЙ МІЖНАРОДНОГО ЕКОНОМІЧНОГО } \\
\text { ПРАВА }\end{array}$ & 86 \\
\hline 10. & LABOR LAW, SOCIAL SECURITY LAW & 93 \\
\hline 10.1 & $\begin{array}{l}\text { Горяінова Н., Видиборець С., Хоменко І., МихайЛиченко Б. } \\
\text { АТЕСТАЦІЯ } \\
\text { ПРАЦІВНИКІВ У ЗАКЛАДІ ВИЩОЇ ОСВІТИ ТА ІІЇ } \\
\text { ПРАВОВЕ РЕГУЛЮВАННЯ }\end{array}$ & 93 \\
\hline 11. & LAND LAW & 99 \\
\hline 11.1 & $\begin{array}{lll}\text { Rudanetska O., } & \text { Berezhnytska } \mathrm{H} . & \\
\text { LEGAL } \quad \text { MECHANISM } \quad \text { FOR } \\
\text { ENVIRONMENTALLY SIGNIFICANT DECISIONS }\end{array}$ & 99 \\
\hline 12. & PUBLIC INTERNATIONAL LAW & 109 \\
\hline 12.1 & $\begin{array}{l}\text { Cherviakova Oksana } \\
\text { ENSURING NATIONAL SECURITY IN A CONFLICT } \\
\text { SOCIETY: PROCESSES AND MECHANISMS OF } \\
\text { TRANSITIONAL JUSTICE }\end{array}$ & 109 \\
\hline 12.2 & $\begin{array}{l}\text { Shchokin Y., Roianova I. } \\
\text { DEMILITARIZED ZONES IN }\end{array}$ & 116 \\
\hline
\end{tabular}




\begin{tabular}{|c|c|c|}
\hline 2.3 & $\begin{array}{l}\text { Сироїд Т.Л., Гавриленко О.А., Шамраєва В.М., Фоміна } \\
\text { Л.О., Тітов Є.Б. } \\
\text { ПРАВО НА СПРАВЕДЛИВИЙ } \\
\text { ПРАКТИКА СУД: ТЕОРІЯ І } \\
\text { ОРГАНІВ У ГАЛУЗІ ПРАВ ЛЮДИНИ }\end{array}$ & 124 \\
\hline 13. & THE CIVIL PROCESS & 136 \\
\hline 13.1 & $\begin{array}{l}\text { Kolobov L. } \\
\text { PROBLEMAL ASPECTS OF } \\
\text { REFORMCONDUCT OF 2016 YEAR }\end{array}$ & 136 \\
\hline 14. & THE CRIMINAL PROCESS & 144 \\
\hline 14.1 & $\begin{array}{l}\text { Karpova N., Verhun I., Melnyk R., Pylypenko Y., Pestsov R. } \\
\text { FEATURES OF CRIMINAL PROCEEDINGS TO } \\
\text { BARRISTERS }\end{array}$ & 144 \\
\hline 14.2 & $\begin{array}{l}\text { Камінська О. } \\
\text { ЗАСТОСУВАННЯ } \quad \text { ПРИМУСОВИХ }\end{array}$ & 153 \\
\hline 15. & THEORY AND HISTORY OF STATE AND LAW & 159 \\
\hline 15.1 & $\begin{array}{l}\text { Маркевич О. } \\
\text { ГУБЕРНСЬКЕ УПРАВЛІННЯ НА УКРАЇНСЬКИХ } \\
\text { ЗЕМЛЯХ У СКЛАДІ РОСІЙСЬКОЇ ІМПЕРІЇ (КІН. ХVIII - } \\
\text { 60-ТІ РР. ХІХ СТ.) }\end{array}$ & 159 \\
\hline 15.2 & $\begin{array}{l}\text { Муляр В. } \\
\text { ВІД СОФІСТІВ ДО Г. ГРОЦІЯ: КОНЦЕПТУАЛІЗАЦІЯ } \\
\text { ПРИРОДНОГО ПРАВА }\end{array}$ & 167 \\
\hline & REFERENCES & 186 \\
\hline
\end{tabular}




\section{SECTION 1. ADMINISTRATIVE LAW}

\subsection{How the professional and communication skills of a mediator affect the outcome of mediation?}

The traditional way of resolving disputes is a trial, where the court is the main participant in the process, as it makes the final decision. An alternative to litigation is mediation, which is sought by the parties to the conflict, who seek to find a solution that is beneficial to both of them. The main task of mediation is the peaceful settlement of a dispute that arose between the parties. Mediation is an emotional process because the parties to the conflict have opposing positions and want to make a decision in their favor. A compromise can only be reached through dialogue. An important role in this process is played by the mediator, who must have the knowledge and experience in resolving conflict situations.

The mediator is a neutral party who helps the parties to resolve a dispute. Despite the fact that he does not make decisions in the case, but controls the process and guides the parties, the mediator plays an important role in mediation, because the effectiveness of the process depends on his skills.

Mediation is one of the ways to resolve conflicts. So, the mediator should have basic knowledge of conflictology - the science of conflict resolution. The mediator should understand the essence of the conflict that has arisen between the parties, be able to determine each of its stages. A conflict is a dispute that arises as a result of differences of opinion or interests of the parties. When opposing positions, ideas, or interests clash - conflict arises, this is the first stage of the conflict.

Once a conflict has arisen between the parties, they become aware of it and openly demonstrate it. Awareness of the conflict is characterized by the fact that one or both parties begin to feel discomfort in communication, which affects their relationship (labor relations, commercial relations, etc.). An open demonstration is that a party takes a certain action to discuss a conflict situation, such as expressing a desire to turn to a mediator to resolve it. 
The central stage of the conflict is its escalation. During this stage, there is a difficulty in building a dialogue, as the parties actively express and defend their position, which is characterized by emotionality. With the help of knowledge and skills, the mediator should control the level of emotionality of the parties during the discussion of the dispute.

The last stage of the conflict is its resolution, which can take two forms: resolving the conflict by concluding an agreement between the parties or concluding mediation if one or both parties are unwilling to negotiate.

Thus, we can conclude that the mediator should have expertise in the field of conflict resolution, as the conflict is a complex phenomenon, and it is necessary to analyze the causes of its occurrence, the stages of its course, and identify possible ways to resolve it.

The mediator must have a number of professional skills acquired during his/her conflict resolution experience and a number of communication skills. Such skills include active listening skills; the ability to ask questions and make clarifications; the ability to analyze a person's emotional state; the ability to conduct a dialogue in a conflict situation, etc.

Active listening involves focusing on the speaker's language, gestures, and emotions. Unlike passive listening, active listening is characterized by the fact that the listener confirms his/her interest through verbal and nonverbal signals.

Nonverbal signals include a smile, a person's body position, eye contact, etc. When the listener smiles, the speaker feels supported, which helps to create a positive atmosphere for communication. Maintaining eye contact is important to confirm the listener's interest, but prolonged eye contact can have a negative aspect, as it can be perceived by the person expressing their position as pressure, especially if he/she is not a very open person. The position of the body can express a person's mood and emotions. Typically, if a person listens carefully, he/she leans forward a little, expressing interest, but if he/she folds arms and moves away, it may indicate secrecy and unwillingness to listen to the speaker [1]. 
SCIENTIFIC APPROACHES IN JURISPRUDENCE

Verbal signals include agreeable (supportive) movements of the head, reminders of the details of the speaker's speech, reflection, clarification, generalization, etc. Agreeable nods indicate that the listener agrees with the speaker. In a conversation between two parties, it is important to remember the most important details. Reflection as a technique allows the listener to demonstrate the understanding of what the speaker said by paraphrasing the most important parts of the speech [1].

Research indicates that most people are not good listeners and ignore $75 \%$ to $90 \%$ of what is said to them. The average listener does not actively listen. Instead of listening to the speaker, most listeners use the "listening time" to think of a response to the speaker's statement. Active listening requires the listener's undivided attention on the speaker by watching and listening to them [2].

Thus, active listening has a positive effect on the speaker. When he/she is feeling supported, he/she behaves more freely and calmly during the conversation, opens up to the listener.

The mediator as a listener should pay equal attention to each of the parties during their speeches, it is important to give the opportunity to express their opinion and position in full. No need to rush with questions, because it can distract the speaker and create a tense atmosphere. The mediator should control the process, and ensure that the other party does not interrupt the interlocutor.

As noted by Thomas Repicky, it is important to avoid communication barriers in mediation because they disrupt dialogue and often escalate the conflict. Communication barriers tend to be antagonistic, face-losing interactions. Such barriers put the other person on the defensive and can invoke a negative response. "You" statement, judging or coercing the other party, self-serving biases, attribution error, and poor interpersonal conflict communication skills are all barriers to communication [2].

John Ford, in his book "Peace at Work", notes that in the process of communicating with the parties, mediators should use a communication technique to provide feedback - the "I" statement technique. "I" statements open up communication. They require you to be honest and direct and include an unspoken request for what you need. Marshall Rosenberg's book, Nonviolent Communication, is based on this simple 
"I" statement technology. It requires that we are able to do four things: to describe what it is we are observing; to identify how we feel about what we have observed; to articulate our needs that are not being met and which give rise to our feelings, and to describe the concrete actions we need to move forward. The four elements that play out in this formula are: When... (describe behavior in non-blaming terms); I feel... (describe your feelings); Because... (describe the impact on your needs); Make a positive behavior request. For example: "I feel frustrated when you start talking before I have finished because I forget what I wanted to say. I would appreciate it if you could let me finish talking first." [3].

On the whole, the mediator's communication skills are extremely important for establishing a constructive dialogue between the parties, which is the key to an effective resolution of the conflict.

One of the main skills of a mediator is the ability to ask questions and make clarifications. The main purpose of the question is to obtain information. By asking questions to the parties, the mediator learns more about the nature of the dispute and its causes. By asking questions, the mediator controls the course of the conversation, which helps to avoid distractions on other topics. Questions are also used to clarify what the speaker has said. Also, the mediator can push the person to a deeper analysis of the topic. For example: when the parties come to a mediator, the main questions are: Why do you need mediation? and Why do you need a certain (satisfying) result? These questions are important because, in some disputes, the parties may not know why they need to be involved in resolving it.

The mediator can use moments of silence between questions and answers to give the parties the opportunity to structure their thoughts and adjust to further communication.

The mediator should be able to reformulate the problem. Parties in a dispute usually define "the problem" as based on the fault of the other party. When a party sees the problem solely in terms of the other side's fault, however, it is difficult for the party to then be flexible in seeking agreement. Fortunately, there are often many accurate definitions of "the problem", and the mediator will usually help the parties seek 
definitions with which they are comfortable and which are not based on blaming the other party [4].

The mediator should be attentive and vigilant. He/she should monitor the statements and actions of the parties, assess the information on its authenticity. These actions help the mediator to find out whether the parties are willing to cooperate or whether the parties are able to agree. He/she must be patient and tactful in dealing with the parties because any exaggeration or raising the voice can negatively affect credibility.

Also, equally important is the appearance of a mediator. Usually, an organized and professional appearance will favorably influence the party. If the Mediator's manner reflects fairness, strength, and efficiency, the party may prove more cooperative and more receptive to questioning [5].

In our opinion, the most important thing for mediation is the presence of complete trust of the parties in the mediator. The basis of a trusting relationship between the parties and the mediator is his impartiality and neutrality. This means that the mediator should not pay more attention and interest to one of the parties. If the mediator discovers the possibility of a conflict of interest, he/she must refuse to conduct the case. This is required by the ethics of the mediator.

The mediator constantly works with different people, and therefore should have certain knowledge in the field of human psychology, and be able to analyze a person's emotional state during mediation. This knowledge helps mediators to resolve conflict situations that arise between the parties during the process. Usually, such situations arise due to the emotionality of the parties. The ability to build a constructive dialogue between the parties to a dispute is a key mediator's skill.

In order to successfully build a dialogue between the parties, the mediator should create an atmosphere in which the parties to the dispute can feel safe. The mediator can use the principle of family relationships. In the family, parents are an authority for their children. Children trust their parents; listen to their opinions and advice. If a problem occurs, parents only offer solutions, but the final decision is made by the children. Similarly, the mediator only directs the parties, who independently find options for 
resolving the dispute. Following the example of the family, the mediator is an authority for the parties to the dispute, who must fully trust him. The mediator does not give any preferences to one of the parties, as well as parents do not discriminate against their children.

Summarizing, the mediator plays an important role in resolving the dispute, so he/she must be a highly qualified specialist, and has a number of professional and communicative skills. 


\section{2 Публічне адміністрування функціонування вільних економічних зон в Україні: питання вдосконалення}

Вдосконалення публічного адміністрування економічного права, як інституту адміністративного права України, передбачає розгляд питань функціонування вільних (спеціальних) економічних зон (надалі - ВЕЗ). Для здійснення оптимізації функціонування ВЕЗ варто звернутись до характеристики моделей оптимізації систем публічного управління, методу системного підходу та контролю як функції менеджменту. Загалом, моделі оптимізації функціонування ВЕ3 можна об’єднати в 2 основні групи:

(1) які зосереджуються на фіксованих показниках та системному підході: планах функціонування (стратегіях, програмах), оптимізації керівних органів до типу та спеціалізації ВЕ3 (кількості структурних підрозділів (іх штату), фіксованих повноваженнях суб'єктів, методах взаємодії між ними), системній політиці пільг, спрощених формах бухгалтерської звітності та інших показниках спец режиму ВЕЗ (стратегічного характеру) для досягнення мети функціонування ВЕЗ;

(2) які акцентують увагу на часі здійснення діяльності й процедурі іï здійснення, ситуативних рішеннях, стосуються оптимального підбору методів вирішення, прийняття та оформлення рішень для конкретної ситуації задля досягнення проміжної мети діяльності суб' єктів ВЕЗ (тактичного характеру), яка пов'язана із загальною метою створення і діяльності ВЕ3 в економіці регіону (однієї чи декількох територіальних одиниць) та України.

Для першої групи моделей оптимізації, автором запропоновано вдосконалити систему управління ВЕЗ, оскільки вона включає суб'єктів, які беруть участь в її функціонуванні (часто виступають з ініціативою створення самих ВЕЗ), приймають рішення щодо стратегії ії розвитку. В основу розробки даної моделі взято інформацію про керівні органи ВЕЗ за кордоном 3 дослідження Сіваченко І.Ю., Кухарської Н.О., Левицького М.А., національну дозвільну систему у сфері господарювання та характеристику світових ВЕЗ (див. використані джерела). Таким чином було розроблено модель роботи органу 
SCIENTIFIC APPROACHES IN JURISPRUDENCE

господарського управління (надалі - ОГУ) для ВЕЗ комплексної спеціалізації на основі організації його структури для виконання основних завдань (див. Схема 1).

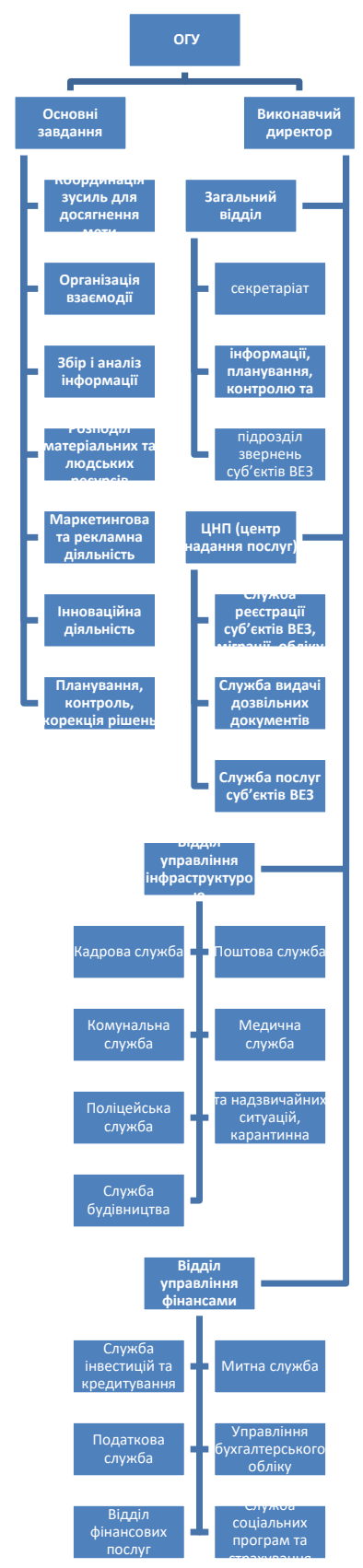

Схема 1 
При цьому, основою для ефективного функціонування такої структури має бути робоча система взаємодії (комунікації) між всіма наведеними структурами (на зразок єдиної бази комунікації).

Також, керівники таких структур як митна та податкова служба призначатимуться відповідними державними органами, які реалізують політику у цих сферах. Для суб'єктів такої ВЕЗ потрібно встановити принцип усунення подвійного оподаткування, для того, щоб сплачені за пільговими ставками доходно-прибуткові податки (корпоративні) за українським законодавством не оподатковувались в інших країнах.

Поліцейська служба формуватиметься та виконуватиме відповідні функції за законодавством України про ії діяльність. Щодо служби охорони - то тут мають бути задіяні суб'єкти ВЕЗ, які надають охоронні послуги.

Медичну службу варто зробити страховою (на основі страхових програм, розроблених службою соціальних програм та страхування), вони повинні мати спрямування на соціальний захист та пов'язані $з$ накопичувальним медичним фондом коштів. Також працівниками даних служб фактично мають бути суб'єкти, зареєстровані у ВЕЗ, які надають відповідні послуги.

Центр надання послуг (ЦНП), виступатиме орендодавцем офісів (на пільгових умовах) для представників суб'єктів господарювання ВЕЗ, які спеціалізуються на послугах, їх логістики, а також для офіційних представників органів публічної влади (з видачі дозвільних документів, реєстрації суб'єктів господарювання та проживаючих осіб тощо - за спрощеною процедурою). Bci інші структури мають комплектуватись із суб'єктів ВЕЗ 3 відповідною спеціалізацією.

Щодо інвестиційних програм, то для залучення інвестицій важливе значення має створення сприятливого інвестиційного клімату.

На основі аналізу досвіду діючих ВЕЗ України та тих, що припинили свою діяльність у 2020 році, варто звернути увагу на основну проблему, яка $є$ несприятливим чинником не тільки для ВЕЗ, але i для всіх суб'єктів 
SCIENTIFIC APPROACHES IN JURISPRUDENCE

господарювання на території України: нестабільність та змінність законодавства і державної політики (різнополярного спрямування). Спочатку створюють ВЕ3 (90 роки 20 століття), потім приходить інша влада і приймає рішення про припинення всіх податкових пільг, які вони мали і переведення їх на загальну систему оподаткування із залишенням вільного митного режиму, який фактично не пов 'язують з ВЕ3, а з митними органами (2005 рік), а залучені інвестори залишаються при своїх інтересах і починають виводити капітал з ВЕЗ (оскільки їм краще вкладати інвестиції у BE3 з стабільною політикою та державним сприянням), продуманими програмами довгострокового розвитку.

У функціонуванні ВЕЗ України існують й інші питання стратегічного значення, що потребують вирішення:

- в визнання ВЕЗ одним з важливих елементів економічної політики держави, основою для залучення інвестицій у проблемні галузі й регіони країни i передбачити їх функціонування протягом тривалого часу (30 і більше років 3 можливістю продовження терміну функціонування);

- вдосконалення програми формування BЕ3 на території України (як на рівні держави так і місцевого самоврядування (в тому числі об'єднаних територіальних громад);

- внесення змін до Податкового кодексу України щодо спеціального режиму ВЕ3, їх податкових пільг (в розділ «спеціальні податкові режими»);

- створити сприятливі умови розвитку інфраструктури BE3 та спрощення і прискорення дозвільних процедур (отримання дозволів, ліцензій, витягів з реєстрів тощо);

• передбачити створення у центральному органі виконавчої влади, який реалізує економічну політику, структурного підрозділу супроводу ВЕЗ, 3 повноваженнями щодо оцінки документів для утворення й функціонування ВЕ3, та їх узгодження із діючими правовими актами України, подання пропозицій до змін законів України (в числі кодифікованих) із метою забезпечення максимального сприяння розвитку ВЕЗ в Україні. 
SCIENTIFIC APPROACHES IN JURISPRUDENCE

Щодо оперативного вирішення питань функціонування ВЕЗ (2 група моделей оптимізації), то вони пов'язані з роботою ОГУ та органів місцевого самоврядування щодо вирішення питань діяльності ВЕЗ. Тут варто здійснювати оптимізацію згідно потреб регіону:

пільги щодо плати за землю, єдиного податку (за спеціальною пільговою ставкою) для суб’єктів ВЕЗ, інші пільги зі зборів, внесків місцевого характеру - вибір за аналізом інвестиційних проектів суб'єктів ВЕЗ;

- $\quad$ пільгові кредити під інвестиційні проекти, інші фінансові послуги (створення мережі фінансових установ);

- розвиток транспортної інфраструктури, логістики, взаємодії між суб'єктами, транспортних терміналів, митних складів тощо;

розвиток соціальної інфраструктури (офіси і готелі, орендні виробничі приміщення, житло, заклади харчування, споруди соціально-побутового призначення (пункти відпочинку, душові, туалети), організація забору, вивезення та переробки сміття тощо), соціальне страхування (змішаного типу 3 накопиченням коштів на персональних рахунках) зареєстрованих суб'єктів ВЕЗ («соціальний пакет»);

- $\quad$ визначення екологічних, будівельних нормативів, розробка правил благоустрою на основі потреб жителів; розвиток взаємодії і співпраці між ВЕ3;

- впровадження навчальних програм, створення або укладення договорів співпраці 3 навчальними закладами для підготовки висококваліфікованих фахівців (можливо, програма пільг для осіб, які зареєстровані, працюють і навчаються на території ВЕ3, направляються на міжнародне стажування чи навчання за кордоном від організацій на території ВE3) та ін.

Варто також звернути увагу на негативні тенденції, які мали місце при функціонуванні ВЕЗ України та пов'язані з використання їх для ухилення від сплати податків, відмивання коштів, одержаних протиправним шляхом тощо. 3 цих причин, а також у зв'язку з податковою реформою, і були припинені пільги у 2005 році та змінилась політика щодо . 3 однієї сторони ВЕЗ сприяють 
збільшенню ВВП, створюють сприятливі умови для розвитку бізнесу, а з іншої, спрощення процедур, пільги можуть використовуватись для шахрайських дій.

Якщо оцінювати переваги та недоліки функціонування ВЕЗ, то переваг більше, а недоліки можна мінімізувати, встановивши систему контролю за виконанням інвестиційних програм та для корекції негативних тенденцій у функціонуванні вільних зон. Варто, щоб контрольна діяльність не перешкоджала суб'єктам господарювання ВЕЗ, але, при вчиненні діянь, які заборонені, та не відповідають меті діяльності відповідної ВЕЗ, особи, які їх вчиняють притягались до відповідальності за законодавством України. У цьому може допомогти електронний кабінет суб'єкта ВЕЗ (за зразком електронного кабінету в податкових відносинах, єдиної автоматизованої системи суду тощо), що забезпечить можливість комунікації, подання документів, надання допомоги, а також контролю за суб'єктами господарювання ВЕЗ. Крім того на сьогодні, поширення набули індустріальні парки.

Як зазначає, Бек Ю.Б., прийняття законів є важливою проблемою, яка потребує вирішення. Зазначені нами зміни варто відобразити у Законі про ВЕЗ, оскільки навіть світова організація зон визначає, що законі має бути розділ про пільги, підприємства ВЕЗ мають звільнялись (чи платити у меншому розмірі) від мит, експортних податків, виплат, квот, ПДВ, інших експортних обмежень, за винятком затверджених міжнародними договорами (угодами).

Проаналізувавши досвід функціонування ВЕЗ у 1999 році Кабінет Міністрів у своїй Постанові визначив, що програма функціонування ВЕЗ (яка була розроблена) має сприяти активізації процесу розвитку й оптимізації їх створення, запровадження спец режимів , але водночас запобігати формуванню надмірної їх кількості і неефективній конкуренції в залученні інвесторів. Реалізація положень програми також пов'язана з втіленням державної політики в сфері створення та відпрацювання принципів управління, механізму функціонування різних типів ВЕЗ. Політика 1999 року пропрацювала до 2005 року. У 2014 році Кримська криза (анексія Криму) спричинила прийняття рішення про створення відповідної BE3. Таке тимчасове рішення можна назвати оптимальним для тодішніх умов, 
SCIENTIFIC APPROACHES IN JURISPRUDENCE

проте питання даної території залишається не вирішеним і наша країна фактично не здійснює управління нею.

На сьогодні, знову варто впроваджувати програму функціонування ВE3, оскільки світовий досвід показує, що наша країна відстає від інших країн у цьому напрямку. 


\section{3 Аналіз вітчизняного та зарубіжного законодавства щодо дотримання прав людини органами національної поліції України}

Сучасне вітчизняне суспільство корінним чином відрізняється від попередніх епох, оскільки основною цінністю визнає саме Людину, ії життя, здоров'я, честь, гідність, недоторканність та інші права, свободи й законні інтереси невладних фізичних і юридичних осіб. 3 метою забезпечення зазначених чеснот об'єктивно функціонує публічний апарат, вершиною якого, з погляду ефективності діяльності, $€$ правоохоронні органи, що мають здійснювати захист громадян від найбільш значних видів небезпеки. Правоохоронна діяльність держави є провідною гарантією забезпечення принципу верховенства права і здійснюється через систему правоохоронних органів, на які безпосередньо покладено функції забезпечення прав і свобод людини та громадянина від найбільших видів небезпеки, охорони громадського порядку; попередження, виявлення, розкриття та припинення правопорушень; надання адміністративних послуг. Серед проблем, які вирішує народ України, однією з найгостріших $є$ проблема здійснення прав людини та громадянина. Для того щоб в повному обсязі реалізувати права, свободи та обов'язки людини і громадяннина, потрібно їх знати та вміти їх захищати. Статтею 19 Конституції правовий порядок в Україні грунтується на засадах, відповідно до яких ніхто не може бути примушений робити те, що не передбачено законодавством. Органи державної влади та органи місцевого самоврядування, їх посадові особи зобов'язані діяти лише на підставі, в межах повноважень та у спосіб, що передбачені Конституцією та законами України. Європейська інтеграціяУкраїни зобов'язує нашу державу забезпечити ефективне функціонування інститутів, які гарантуватимуть верховенство права, додержання прав і свобод людини і громадянина, їх ефективний захист. Одним із таких завдань $є$ утворення МВС України як цивільного органу європейського зразка.

Ключові слова: права людини, інтеграція, національна поліція, порушення прав людини,законодавчі новації. 
SCIENTIFIC APPROACHES IN JURISPRUDENCE

Інтеграція до європейських інституцій відкриває Україні шлях до більш широкої участі в структурах міжнародної безпеки, забезпечує можливість спільних дій України та ЄС щодо боротьби зі злочинністю. У цьому контексті ефективна та цілеспрямована діяльність Міністерства внутрішніх справ із розгалуженою системою представників $\mathrm{MBC}$ за кордоном стає важливим чинником стабільності й безпеки. Зважаючи на викладене, МВС упродовж 20142015 років ужито низку заходів щодо реформування органів внутрішніх справ України на органи Національної поліції України[13].

Дуже багато вітчизняних вчених досліджують це питання. Деякі з них: В. Авер'янов, І. Арістова, О. Бандурка, В. Басс, В. Бевзенко, О. Безпалова, Ю. Битяк, Л. Біла-Тіунова, В. Білоус, І. Бородін, В. Галунько, В. Гаращук, Ю. Гаруст, І. Голосніченко, С. Гончарук, І. Гриценко, Т. Гуржій, С. Гусаров,

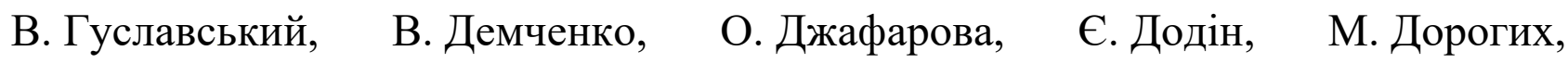
А. Слістратов, В. Заросило, А. Іванищук, Р. Калюжний, В. Ковальська, А. Комзюк, С. Ківалов, В. Коваленко.Але через постійні зміни в суспільному житті та недосконалості законодавства, питання і по сьогодні залишається актуальним.

Законодавці та експерти нашої країни запозичують ефективний досвід зарубіжних країн з метою акумщого досвіду для ефективного закінчення реформ. Тому для аналізу беруть досвід, наприклад Франції, в правовій системі якої в організації слідчого апарату є самостійність слідчих суддів, підкорення їх лише закону, відсутність стороннього втручання в розслідування кримінальних справ. Певними повноваженнями під час розслідування злочинів наділений суддя зі свобод і ув'язнень. Контролює діяльність слідчих суддів слідчий орган, у роботі якого беруть участь судді апеляційного суду. Їхній процесуальний статус характеризується такими основними суттєвими ознаками: суддя діє в складі суду та призначається і звільняється з посади Президентом за поданням Міністра юстиції; рішення слідчий суддя приймає самостійно, крім взяття під варту; проводить слідчі дії, але позбавлений права порушувати кримінальну справу, пред’являти особі обвинувачення, складати обвинувальний акт після закінчення 
SCIENTIFIC APPROACHES IN JURISPRUDENCE

розслідування. Усі дії слідчого судді можуть бути оскаржені. Прокурор не наділений правом давати слідчому судді вказівки, обов’язкові для виконання, скасовувати його рішення. Слідчий суддя має право самостійно накладати значні штрафи на осіб, які неналежним чином виконують процесуальні обов'язки[14].

У своїй діяльності Міністерство внутрішніх справ України має керуватися положеннями Угоди про асоціацію між Україною, 3 однієї сторони, та Європейським Союзом, з іншої сторони, що визначає якісно новий формат відносин з СС на принципах «політичної асоціації та економічної інтеграції» та є стратегічним орієнтиром системних реформ в Україні й перебудови системи правоохоронних органів зокрема [15].

Правоохоронна сфера в усі часи була однією з умов формування правової держави, адже вона є гарантом створення чіткого механізму контролю за правопорядком і законністю в суспільстві. Свропеїзація суспільства, прагнення інтеграції в європейський простір, захист прав, свобод громадян, демократизація зумовлюють необхідність побудови якісно нової моделі правоохоронних органів, які відіграють визначальну роль у захисті прав і свобод людини та громадянина. Поширеність корупції в усіх ешелонах влади, зокрема і в самій правоохоронній сфері, свідчить про недосконалість i неефективність функціонування цих органів. «Телефонне право», лобіювання інтересів, порушення Свропейської конвенції з прав людини, низький професійний рівень вимагають негайної розробки державної політики щодо реформування, удосконалення та оптимізації правоохоронних органів, зокрема органів внутрішніх справ. А якщо взяти до уваги значні резонансні злочини , які скоїли поліцейські, то можемо сказати точно, що працювати ще є над чим.

Потреба реформування правоохоронної системи закріплена на законодавчому рівні. Відповідно до ст. 8 Закону України «Про основи національної безпеки України» «реформування правоохоронної системи з метою підвищення ефективності іiі діяльності на основі оптимізації структури, підвищення рівня координації діяльності правоохоронних органів, покращення їх фінансового, матеріально-технічного, організаційно-правового і кадрового 
забезпечення» $є$ одним 3 основних напрямків державної політики 3 питань національної безпеки України у сфері державної безпеки[16].

Відповідно до ст. 38 Конституції України громадяни мають право брати участь в управлінні державними справами[17]. Прикладами такої участі громадян сталивключення представників громадськості до складу атестаційних комісій, запрошення їх до участі в роботі колегій. Зазначеним заходам сприяло формування при МВС України та обласних управліннях громадських рад iз питань забезпечення прав людини, створення Управління моніторингу дотримання прав людини в діяльності органів національної поліції, що істотним чином вплинуло на рівень довіри суспільства до поліції та розширення i зміцнення таких відносин у майбутньому.

Відомчий контроль за забезпеченням прав i свобод громадян в адміністративній діяльності поліції є одним із видів контролю як функції управління і становить діяльність зі спостереження, аналізу й перевірки об'єктів контролю (органів та підрозділів поліції, працівників поліції), що спрямована на запобігання, виявлення та припинення дій, що суперечать установленим законодавством України та міжнародними правовими актами нормам правилам і стандартам у сфері захисту прав і свобод людини та громадянина.

Окремим напрямком діяльності правоохоронних органів є розроблення алгоритму дій під час охорони мирних зібрань із метою забезпечення права громадян на свободу слова, вираження поглядів і переконань. У поліцейських підрозділах має бути запроваджено спеціальне навчання персоналу з метою забезпечення прав людини під час службової діяльності. Випадки застосування сили та фізичного примусу під час таких заходів мають бути чітко регламентовані нормативними приписами, у переважній більшості санкціоновані й ретельно розглянуті керівництвом поліції разом 3 іншими органами, що контролюють діяльність поліції, 3 обов’язковою участю громадськості. Узагалі кажучи, парламент мав би ухвалити Закон про свободу мирних зібрань, в якому передбачити всі дії поліції в ситуаціях, які виникають під час мирних зібрань[18]. 
SCIENTIFIC APPROACHES IN JURISPRUDENCE

Одним способом вирішення недосконалості законодавства, що регламентує повноваженняправоохоронних органів у сфері забезпечення особистих прав людини, є своєчасна ротація застарілих правових актів на більш досконалі й ефективні. Удосконаленню підлягають не тільки закони, а й відомчі нормативно-правові акти, особливо органів національної поліції. Їх головне призначення полягає в тому, що вони маютьустановлювати не повноваження окремих структурних підрозділів, а здійснювати розподіл загальної компетенції в сфері забезпечення конституційних особистих прав людини, яка вже визначена вищими за юридичною силою правовими актами, між підрозділами національної поліції відповідно до поставлених перед ними завдань, а також враховуючи сили та засоби, якими вони володіють.

Таким чином, можемо зробити висновки, що сфера адміністративноправового забезпечення дотримання прав людини в правоохоронних органах України як системи еволюційних і революційних правотворчих заходів в умовах сучасних викликів побудована на людиноцентристській теорії адміністративного права та виконанні міжнародних зобов'язань України перед Європейською Спільнотою щодо утвердження принципу верховенства права та поваги до прав людини й основоположних свобод. 


\section{SECTION 2. BANKING LAW}

\section{1 Суб'єкт контролю за діяльністю банків в Україні. Діяльність фонду гарантування вкладів фізичних осіб}

Діюча система гарантування вкладів фізичних осіб насьогодні $є$ дієвим механізмом захисту прав та охоронюваним законом інтересів вкладників, у разі неспроможності виконання своїх зобов'язань банками, що дозволяє виконувати завдання щодо захисту їх матеріальних інтересів та заощаджень від негативних наслідків банкрутства банків, підвищення довіри до банківського сектору, а також підтриманння соціально-економічної стабільності у країні.

Робота системи гарантування вкладів фізичних осіб (надалі СГВФО) уможливлює збільшення пасивів комерційних банків України. Для вкладників банків ця система являє собою один із факторів, спонукаючих інвестувати гроші в банки і отримувати певний дохід.

Один з факторів, що виконує Фонд гарантування вкладів фізичних осіб - це повернення їх заощаджень при умові визнання банку неплатоспроможним. Це допомагає збереженню можливостей банку щодо питання виконання ним своїх обов'язків перед користувачами їх послуг тобто вкладниками, забезпечує Часткове збереження державних коштів, вагомо підвищує довіру до банківської системи [19].

В той же час ефективна робота СГВФО не являє собою гарантію забезпечення платоспроможності банків. Тому за даними Фонду на етапі ліквідації перебувають близько 90 банків [20].

Головними причинами великого збільшення кількості неплатоспроможних банків та банків, що перебувають на етапі ліквідації в Україні, являє собою недосконалість законодавчого забезпечення та низька ефективність контролю за їх діяльністю. 
SCIENTIFIC APPROACHES IN JURISPRUDENCE

У наукових роботах особливу увагу дослідженню регуляторної діяльності Фонду приділяли О. Б. Билінська [19], А. Г. Бухтіарова [21], В. І. Огієнко [22], В. В. Коваленко [23] та інші. Аналізуючи та роблячі висновки результатів попередніх досліджень з цієї проблематики, можна констатувати, що в данний час перегляду потребують деякі положення законодавства щодо визначення виняткових особливостей регуляторної діяльності Фонду в діючій СГВФО, інструментарію іiі здійснення тощо, що і обумовило вибір теми.

Мета: дослідити основні аспекти забезпечення роботи функцій СГВФОта регулювання Фонду, зокрема особливих дій здійснення ним функції контролю за діяльністю банків і визначення можливості удосконалення правового регулювання в даній сфері.

Одним з найголоніших цілей Фонду є забезпечення роботи функціоналу СГВФО і видалення неплатоспроможних банків з ринку. Для виконання цього завдання перш за все, Фонд акумулює фінансові кошти, отримані з указаних Законом України «Про систему гарантування вкладів фізичних осіб» джерел, виконує пильний контроль за цілісністю та своєчасністю перерахування зборів кожним членом Фонду(ст. 4 Закону) [24].

Головним джерелом організації коштів Фонду в період стабільності банківського сектору та маленької кількості обанкрутілих банків є регулярний чіткий збір. Він складає більше $80 \%$ від існуючих банківських надходжень. А. С. Скірка та Б. П. Адамик зупиняють свою увагу на тому, що регулярного збору недостатньо навіть для відшкодування вкладів кредиторам банку, тому що в середньому за останні роки він становить 3,5 млрд. грн., в той час коли виплати гарантованої суми вкладникам неплатоспроможних банків - у вісім разів більше. Тому і виникає зріст морального ризику із боку власників банків [26].

Виходом з цього положення може бути збільшення коштів Фонду за рахунок значного збільшення можливостей використання диференційованого підходу до нарахування регулярних зборів банками-учасниками. Тоді пропонуємо змінити підхід до обчислення регулярного диференційованого збору 
SCIENTIFIC APPROACHES IN JURISPRUDENCE

зробивши розподіл бази його нарахування на дві групи: основну та додаткову. Регулярні збори за основною базою нарахування повинні здійснюватися згідно 3 ч. 1 ст. 22 Закону України «Про систему гарантування вкладів фізичних осіб»; за додатковою - шляхом значного збільшення базової річної ставки пропорційно до збільшення всієї суми граничного розміру відшкодування за вкладами за ініціативою окремих банків. Вказані рекомендації стосовно нарахування регулярного диференційованого збору пропонується додати до Порядку розрахунку розмірів регулярних зборів до Фонду у формі диференційованих зборів, прийнятого згідно з Рішенням виконавчої дирекції Фонду гарантування вкладів фізичних осіб від 2 липня 2012 р. № 1, зареєстрованого в Міністерстві юстиції України 27.07.2012 № 1273/21585 [27].

Наведені приклади змін дозволять збільшити кошти Фонду, а отже зможуть у разі відкликання ліцензії та ліквідації банку, сприяти своєчасному виконанню зобов’язань щодо відшкодування вкладів.

Крім того вимагає правого регулювання питання з боку розширення курсів розміщення коштів Фонду, організація яких повинна забезпечувати певний рівень ліквідності.

Скажімо окремо існує необхідність дозволення Фонду інвестувати кошти окрім державних цінних паперів в іпотечні цінні папери, що створить можливості для диверсифікації ризиків, пов'язаних з відсутністю достатнього обсягу коштів для виплати відшкодування вкладникам у раніше встановлений строк [28].

Відповідно до п. 2 ч. 1 ст. 30 Закону Фонд здійснює управління та контроль над роботою банків шляхом контролювання за виконанням зобов'язань банків через їх участю в СГВФО [24]. Тобто законодавець встановив те, що контроль здійснюється Фондом в межах банківського регулювання, є його частиною.

Реалізація Фондом функції контролю за діяльністю банків дотримується 3 урахуванням такого моменту: ключовою метою контрольної діяльності Фонду є забезпечення дотримання банками-учасниками СГВФО вимог, затверджених 
SCIENTIFIC APPROACHES IN JURISPRUDENCE

нормативно-правовими актами Фонду стосовно своєчасного поданням звітів за формою, встановленою чинним законодавством та перевірка виконання обов'язків банків пов’язаних з їх присутністю в СГВФОзгідно 3 п. 2 ч. 1 ст. 30 Закону) [24].

Беручи до уваги зазначене, помітно, що контроль за діяльністю банків з боку Фонду потрібно розуміти як комплекс впорядкованих дій Фонду, націлених на спостереження за роботою банків-учасників СГВФО, перевірку дотримання ними законодавства України з ціллю забезпечити виконування обов'язків банків пов’язаних з їх участю в СГВФО, виявлення порушень, притягнення винних осіб до відповідальності, надання рекомендацій щодо їх скорішого усунення.

Отже, контроль з сторони Фонду за діяльністю банків є управлінською діяльністю, яка може реалізуватися в межах регулюючої діяльності Фонду.

Варто звернути увагу, що контрольна діяльність Фонду неспроможна без застосування інструментів відповідного контролю.

C. В. Башлай підкреслює, що підтримання державним органом безперебійного функціонування банківської системи країни передбачає уживання економічних, регулятивно-наглядових і стабілізаційних заходів. Але вчений зауважує, що головний інструментарій реалізації наглядових функцій уповноваженими органами різних держав майже однакові і передбачають такі дії:

• установлення та нагляд за чітким виконанням регулятивних вимог;

• постійний дистанційний моніторинг, дослідження звітності та аналіз фінансового стану банку;

• епізодичні проведення тематичних або комплексних перевірок діяльності банку на місці (інспектування чи вивчення висновків зовнішніх аудиторів);

• вживання заходів впливу на банк (попередження, штрафи, обмеження та відкликання ліцензії, введення зовнішнього управління банком та ін.) [29]. 
SCIENTIFIC APPROACHES IN JURISPRUDENCE

Згідно зі ст. 31 Закону банк повинен в обов'язковому порядку надавати до Фонду балансові звіти, звіт аудитора, та інші зазначені Фондом форми звітності, документи та інформацію, необхідні задля виконання Фондом цілей, заздалегідь передбачених саме цим Законом, у визначені строки та формі встановлених нормативно-правовими актами Фонду. Таким чином, одним із інструментів контролю є постійна перевірка звітів Фондом [24].

Крім того, згідно зі ст. 32 Закону Фондом здійснюються планові та позапланові перевірки банків-учасників СГВФО задля їх контролю. Фонд також має право перевіряти банк щодо виконання ним зобов'язань пов'заних з участю в СГВФО щодо:

• правдивості наданої Фонду звітності;

• вичерпність і своєчасності розрахунків з Фондом за зборами до Фонду та нарахованою пенею;

• вичерпність і правдивості ведення бази даних про вкладників;

• дотримання вимог щодо інформування вкладників про участь банку у Фонді;

• дотримання інших вимог Закону та нормативно-правових актів [24].

У деяких ситуаціях Фонд має право проводити позапланові перевірки або відповідно до ст. 32 Закону приєднуватись до інспекційних перевірок НБУ, за власним клопотанням, шляхом залучення працівників Фонду для проведення інспекційних повних перевірок банків та їх додання до складу інспекційної групи. Для працівника Фонду, що входить до складу інспекційної групи НБУ виконавчою дирекцією Фонду затверджується окремі етапи перевірки [24].

У разі становлення банку до категорії проблемних, Фонд володіє правом виконувати незаплановану перевірку такого банку з інших питань та сторін діяльності, крім передбачених Законом, перелік яких визначаєтся виконавчою дирекцією Фонду з ціллю накопичення інформації для підготовки плану врегулювання проблемного банку у разі його віднесення до розділу 
SCIENTIFIC APPROACHES IN JURISPRUDENCE

неплатоспроможних, водночас 3 метою визначення вартості активів проблемного банку (ч. 7 ст. 32 Закону) [24].

Тобто, шляхом роз'яснення наведених норм Закону можна спробувати зробити висновок, що Фонд має повне право здійснювати як документальні, так і фактичні перевірки банків задля впевненості в виконанні ними зобов’язань пов'язаних з присутністю в СГВФО.

Окрім того, Фонд має повне право вимагати від визначеного банку подання інформації з цікавлячих фонд питань функціонування. Банк в той самий час зобов’язаний надати таку інформацію до Фонду у визначені час та в формі, визначених відповідною до ситуації вимогою Фонду. Банки зазвичай надають інформацію, що може містити в собі банківську таємницю, у порядку, визначеному в ст. 62 Закону України «Про банки і банківську діяльність» [30].

Таким чино ще одним методом контролю банків з боку Фонду є запити про надання інформації. Згідно з ч. 1 ст. 33 Закону в разі порушення банками законодавства про СГВФО Фонд, адекватно вчиненому порушенню, виконуе дії направлені на банки адміністративно-господарські санкції у вигляді письмового застереження або штрафу чи розпорядження щодо усунення порушень законодавства про СГВФО[24].

Звернімо увагу на те, що відповідно до ст. 238 Господарського кодексу України адміністративно-господарські санкції визначаються як заходи організаційно-правового або майнового характеру, що можуть бути застосовані до суб’ єктів господарювання органами державної влади або органами місцевого самоврядування за порушення встановлених законодавчими актами правил виконання господарської діяльності, націлені на припинення правопорушення суб’єкта господарювання та ліквідацію його наслідків [31].

О. П. Подцерковний вважає ці санкції однією з багатьох форм господарськоправової відповідальності [32]. Однак О. П. Рябченко підкреслює, що їх краще розглядати як вид адміністративної відповідальності [33]. 
SCIENTIFIC APPROACHES IN JURISPRUDENCE

Н. Ю. Кантор звертає нашу увагу на те, що ці санкції мають не тільки репресивний, а також й правозахисний характер, і спрямовані на забезпечення умов для розвитку й реалізації економічних інтересів України. Звідси виходить, що й мета адміністративно-господарських санкцій неоднорідна: за своїм цільовим призначенням вони мають можливість мати припинення подальших правопорушень у процесі виконання господарської діяльності, відновлення порушених прав, забезпечення належної реалізації норм законодавства або покарання за скоєне правопорушення [34].

Мається на увазі, що про належність адміністративно-господарських санкцій, застосовуваними Фондом до одного 3 видів адміністративної відповідальності свідчить те, що вони:

• діють не за порушення договірних зобов’язань;

• повноваженнями задля їх застосування наділений Фонд;

• діють з цілью завершення вчиненого порушення і ліквідації його наслідків;

• виконуються в адміністративному порядку;

• передбачають не тільки використання лише визначених заходів майнового характеру, а й мають можливість передбачати припинення подальших правопорушень у ході здійснення банківської діяльності, відновлення порушених прав, забезпечення відповідної реалізації норм законодавства.

Важливу роль у поясненні суті адміністративно-господарських санкцій $\epsilon$ підхід, який використовує більшість науковців, — визначення їх як покарання. Таким чином, А. Й. Іванський під визначенням «санкції» розуміє міри (заходи) примусового впливу за порушення визначеного порядку діяльності, які мають попереджувальну, компенсаційну чи репресивну функції [35]. Також санкції можна визначити як заходи, що уживаються до правопорушника та спричиняють для нього несприятливі наслідки. 
SCIENTIFIC APPROACHES IN JURISPRUDENCE

Зважаючи на сутність поняття «санкції», ясно, що вони володіють негативними наслідками для правопорушника, в той же час, коли заходи впливу, направлені на попередження банку.

Тому пропонувати роділити наявні санкції та заходи попереджувального характеру. Останні слід віднести до заходів впливу, що не несуть негативних наслідків в бік суб’єкта вчинення правопорушення.

Ще слід звернути увагу на те, що відповідно до п. 8.4 «Положення про порядок накладання адміністративно господарських санкцій Фондом гарантування вкладів фізичних осіб», затвердженого Рішенням Виконавчої дирекції ФГВФОвід 23.07.2012 № 11 [36] Фонд у письмовому застереженні звертає увагу банку на виявлені порушення законодавства щодо гарантування вкладів фізичних осіб, в тому рядуі нормативно-правових актів Фонду, або недсконалості в роботі та за вимоги конкретні заходи, яких йому потрібно вжити з метою їх видалення та неприпущення надалі. Разом з цим, рішення по справі у вигляді письмового застереження має містити вимоги щодо видалення порушення законодавства щодо СГВФО або вживання дій щодо неприпущення таких порушень надалі.

Підкреслюючи вказане 3'являється питання щодо розмежування таких адміністративно-господарських санкцій як письмове застереження та розпорядження щодо виключення банком порушень вимог законодавства про СГВФО. Тоді як одне, так і інше має можливість містити вимоги про усунення порушення законодавства щодо СГВФО, то їх слід розмежовувати.

Через це прявляється, що у письмовому застереженні необхідно вказувати не на порушення законодавства, а на усі недосконалості в роботі та звичайно при потребі конкретних заходів, які йому потрібно вжити з ціллю їх виключення та неприпущення надалі.

Тож, можу пропонувати до адміністративно-господарських санкцій, що застосовує Фонд до банків, відносити штраф та розпорядження про видалення 
порушень законодавства щодо СГВФО, а письмове застереження відносити до попереджувальних заходів впливу.

Ревізія діяльності банків з боку Фонду потрібно розуміти як сукупність впорядкованих процесів Фонду, спрямованих на спостереження за роботою банків-учасників всієї СГВФО, ревізія дотримання цими банками законодавства України з ціллю забезпечення виконання обов'язків банків що пов'язані з їх знаходженням у СГВФО, пошук порушень, притягнення винних осіб до відповідальності, надання рекомендацій щодо їх виключення. Беручи до уваги зазначене, інструменти контролю за діяльністю банків з боку Фонду являють собою: документальні та фактичні ревізії банків, запити про надання інформації, адміністративно-господарські санкції.

Перспективним напрямком досліджень надалі є розробка підстав, при яких призначається адміністративно-господарські санкції у вигляді письмового застереження або розпорядження щодо усунення порушень законодавства України про СГВФО. 


\section{SECTION 3. CIVIL LAW}

\section{1 Становлення та розвиток в Україні системи правової охорони промислової власності}

Промислова власність $є$ важливим інструментом економічного та технологічного розвитку країни, яка тісно пов'язана 3 підвищенням рівня виробництва, що сприяє розвитку ринкової економіки. На сьогодні важливим завданням для України $є$ створення ефективної інноваційної системи, яка спроможна забезпечити технологічну модернізацію української економіки, підвищити іiі конкурентоспроможність на основі безпечних передових технологій. Насамперед виразно це проявляється в сучасних умовах зростання значення інновацій, швидким розвитком міжнародної торгівлі та промисловості, технологічного обміну, створення глобального інформаційного простору. Тому необхідно удосконалити в Україні систему правової охорони промислової власності, ринок результатів інтелектуальної, творчої діяльності, та перетворити науковий потенціал країни в дієвий ресурс економічного зростання. Майбутнє українського суспільства та держави залежить від розвитку законодавства у сфері промислової власності, інститутів пї охорони та захисту, в тому числі й цивілізованого використання.

В період панування радянської влади в Україні об’єкти права промислової власності були практично виведені з торгового обігу, також був відсутній національний ринок торговельних марок, ліцензій тощо. Настав час активно запроваджувати економіку, засновану на інноваціях, знаннях та інтелектуальних активах. За таких умов стимулювання розвитку правової охорони об’єктів права промислової власності набуває ролі одного з найважливіших чинників усього комплексу політико-економічних відносин та економічної безпеки як усередині кожної цивілізованої країни, так і на міжнародному рівні.

Підвищена увага до цих правовідносин зумовлена також міжнародними зобов’язаннями України, зокрема вступом до Світової організації торгівлі, що неможливо було здійснити без виконання вимог Угоди про торговельні аспекти 
SCIENTIFIC APPROACHES IN JURISPRUDENCE

прав інтелектуальної власності (далі - Угода ТРІПС) [37], підписанням 27 червня 2014 року Угоди про асоціацію між Україною, з однієї сторони, та Європейським Союзом, Свропейським співтовариством з атомної енергії і їхніми державамичленами, з іншої сторони (далі - Угода про асоціацію) [38]. Обраний Україною шлях інтеграції в Європейський Союз потребує максимального наближення законодавства України до законодавств країн-членів ЄС. Необхідно зазначити, що Угода про асоціацію містить значну кількість чинних у межах Європейського Союзу правових норм щодо охорони прав промислової власності, які мають бути імплементовані в українське законодавство. Актуальність розв'язання цього питання очевидна, оскільки це дозволить визначити конкретні заходи, які сприятимуть вступу України в Свропейський Союз.

Характерною особливістю правового регулювання промислової власності $€$ тісний взаємозв' язок міжнародного, національного та європейського права в цій сфері. Так, міжнародна охорона прав на об’єкти промислової власності передусім формується на основі ряду універсальних міжнародних договорів, основними з яких є Паризька конвенція з охорони промислової власності, Мадридська угода про міжнародну реєстрацію знаків та Протокол до Мадридської угоди, Конвенція про заснування Всесвітньої організації інтелектуальної власності, Договір про патентну кооперацію, Договір про патентне право, Угода ТРІПС. Саме ці акти ввели ті принципи, які нині запроваджені у національне законодавства більшості країн світу, у тому числі й в Україні. Слід також зазначити, що існують і інші міжнародні універсальні договори про охорону промислової власності. Створення в Україні сучасної системи промислової власності неможливе без гармонізації національного законодавства 3 нормами міжнародного права. Саме на базових принципах та положеннях, вироблених міжнародною практикою (зокрема, поняття об'єктів інтелектуальної власності, критерії охороноздатності, суть режимів правової охорони тощо) й розбудовувалося чине національне законодавство у сфері інтелектуальної власності. 
Пропонується розглянути, як відбувалось становлення в незалежній Україні інституту права промислової власності. Так, до 1991 року в УРСР, як і в усьому колишньому Радянському Союзі, через панування соціалістичної ідеології та суспільної форми власності були відсутні спеціальні законодавчі акти у сфері охорони прав промислової власності. Правове регулювання відносин у цій сфері забезпечувалося переважно підзаконними актами. Виключенням було Положення про відкриття, винаходи й раціоналізаторські пропозиції 1973 р. [39] та розділ VI Цивільного кодексу Української РСР від 18 липня 1963 р. [40]. Спеціальне законодавство у сфері промислової власності почало формуватися після проголошення незалежності України. Тимчасове положення про правову охорону об’єктів промислової власності та раціоналізаторських пропозицій в Україні від 18 вересня 1992 р. [41] стало першим нормативно-правовим актом у сфері охорони прав на об'єкти промислової власності в Україні, який був прийнятий після легалізації приватної власності. Попри те, що введення в дію цього положення було тимчасовим заходом, даний нормативний акт став основою для створення правової бази у сфері охорони прав промислової власності. Тимчасовим положенням 1992 р. була запроваджена єдина патентна форма охорони винаходів, корисних моделей і промислових зразків. Також завдяки Тимчасовому положенню 1992 р. стало можливим в стислі строки організувати прийняття заяв і видачу патентів на об'єкти промислової власності та розв'язати питання перереєстрації охоронних документів колишнього СРСР на території України.

Наступним кроком стало прийняття Верховною Радою України пакету законів про охорону прав на об’єкти промислової власності. Так, 15 грудня 1993 p. були прийняті три фундаментальні законодавчі акти у сфері промислової власності: «Про охорону прав на промислові зразки» [42], «Про охорону прав на знаки для товарів і послуг» [43], «Про охорону прав на винаходи і корисні моделі» [44]. За Законом України «Про охорону прав на винаходи і корисні моделі» 1993 р. право на одержання патенту мали винахідник, роботодавець, правонаступник винахідника чи роботодавця та Фонд винаходів України й це 
було дуже доречно. Саме Фонд винаходів України мав здійснювати функції володільця майнових прав на патент від імені держави та в іії інтересах. Проте Фонд винаходів України так і не був створений, до того ж у новій редакції цього самого Закону про нього взагалі не згадується. Отже, держава Україна так і не створила практичного механізму здійснення свого права на об' єкти промислової власності.

У 1996 році в Україні відбулася видатна подія для всього українського народу - прийняття Конституції України [45]. Конституція України чітко визначила принципові засади державної політики й у сфері інтелектуальної власності. Зокрема, стаття 41 Конституції України надала право володіти, користуватися i розпоряджатися своєю власністю, результатами своєї інтелектуальної, творчої діяльності. Стаття 54 Конституції проголосила свободу наукової, науково-технічної, художньої та іншої творчості.

У червні 2000 року був прийнятий Закон України «Про внесення змін до Закону України «Про охорону прав на винаходи і корисні моделі» [46]. Але у новому законі замість простого й чіткого режиму здійснення та набуття прав на винаходи й корисні моделі, який діяв раніше, було затверджено громіздку систему з шести різновидів патентів і для отримання кожного з яких установлено окремі правові підстави. Тому урядом України були намічені шляхи до подальшого приведення законодавства України у сфері промислової власності у відповідність до міжнародних норм.

Таким чином, за роки незалежності України були розроблені, прийняті та введені в дію основні законодавчі акти з охорони прав на об'єкти промислової власності. Нарешті в Україні відбулися значні зміни та ефективне використання об’єктів права промислової власності почало приносити творцям та іншим правоволодільцям вагомий прибуток. Цими нормативно-правовими актами була закладена основа системи правової охорони промислової власності в Україні. Проте, не можна вважати становлення українського законодавства про промислову власність завершеним, цей процес триває. I, як зазначали автори [47, 48], національне законодавство у сфері промислової власності хронічно 
SCIENTIFIC APPROACHES IN JURISPRUDENCE

відставало від потреб часу і не забезпечувало охорону промислової власності. У зв'язку з тим виникла потреба перегляду законодавства і прийняття низки нових нормативних актів як на рівні профільного законодавства, так і на рівні кодифікованих актів. Тому важливим законодавчим актом у сфері інтелектуальної власності став прийнятий 16 січня 2003 року Цивільний кодекс України [49]. Цілком погоджуюся з позицією видатних українських науковців $[50,51]$, що новий Цивільний кодекс України грунтується на принципово новій - приватноправовій концепції регулювання особистих немайнових та майнових відносин, що засновані на вільному волевиявленні, юридичній рівності та майновій самостійності їх учасників.

За роки існування Радянського Союзу право на творчий результат у більшості випадків належало державі. Відомий радянський науковець сфери промислової власності В. Р. Скрипка зауважував, що, попри те, що радянським законодавством передбачалося дві форми охорони винаходу - авторське свідоцтво та патент, 99 \% винахідників подавали заяви на видачу їм саме авторських свідоцтв, а не патентів [52]. У ті часи патентна форма скоріше існувала завдяки міжнародній політиці й становила інтерес тільки для іноземних заявників. А оскільки у СРСР засоби виробництва не могли знаходитися у приватній власності, радянський винахідник як власник патенту не мав можливості організувати промислове застосування свого об'єкта права. Нині основним положенням Цивільного кодексу України є визнання майнових прав на результати інтелектуальної, творчої діяльності. Згідно зі ст. 421 Цивільного кодексу України первинним суб'єктом інтелектуальної власності є творець об’єкта права і це доречно. Відповідно до ч. 1 ст. 462 Цивільного кодексу України набуття права інтелектуальної власності на винахід і корисну модель засвідчується патентом, на промисловий зразок - свідоцтвом. Проте наразі ЦК України в стадії рекодифікації. Головними чинниками сучасної рекодифікації ЦК України є: європейська тенденція до уніфікації й гармонізації приватноправового регулювання; новітні реформи приватного права в країнах $\mathrm{CC}$, зокрема, розробка 
і прийняття нових законів, модернізація цивільно-правових кодифікацій 3 урахуванням міжнародних та $є$ вропейських норм .

Міжнародне співробітництво у сфері охорони промислової власності має великий вплив на інвестиційні та інноваційні процеси в Україні, на розвиток зовнішньої торгівлі та підприємництва. Тому після проголошення незалежності Україна заявила про подовження на її території дії Паризької конвенції з охорони промислової власності, Договору РСТ, Мадридської угоди про міжнародну реєстрацію знаків. Також Україна приєдналася до таких основних універсальних міжнародних договорів як, наприклад, Договір про закони щодо товарних знаків, Протокол до Мадридської угоди про міжнародну реєстрацію знаків. Все більше визнання находять регіональні патентні союзи як, наприклад, Європейська патентна конвенція. Йдеться про тенденцію зближення національних систем у сфері охорони промислової власності. Наміри України - інтегруватись до Європейського Союзу. Для цього Україні потрібно вирішити чимало проблемних питань, одним з яких є формування в державі цивілізованого ринку промислової власності.

Таким чином, актуальність питання удосконалення законодавства про правову охорону об'єктів права промислової власності, в першу чергу, зумовлена необхідністю адаптації українського законодавства до норм права Європейського Союзу та положень Угоди про асоціацію.

Отже, в Україні закладено основи законодавчої бази у сфері охорони прав на об’єкти промислової власності, для розробки й прийняття якої була використана значна частина наукових праць і застосований як міжнародний, так і вітчизняний досвід. Можна зробити висновок, що в цілому законодавство України у сфері промислової власності відповідає міжнародним нормам та вимогам ринкової економіки. Проте беззаперечним $є$ факт окремих недоліків чинного законодавства у сфері охорони прав на об’єкти промислової власності та його недосконалість, що вимагає грунтовного теоретичного дослідження з метою удосконалення національного законодавства та врегулювання правовідносин у даній сфері. Наразі Україні потрібно спрямувати головну увагу на європейське 
SCIENTIFIC APPROACHES IN JURISPRUDENCE

законодавство. Для сучасного етапу розвитку європейського законодавства у сфері промислової власності характерним є процес універсалізації законодавств країн-членів СС з метою подолання будь-яких перешкод на шляху впровадження та практичного використання об’єктів права промислової власності в єдиному просторі Спільноти.

Для узгодження законодавства України у сфері охорони прав промислової власності 3 відповідним законодавством Свропейського Союзу на сьогодні в українському законодавстві відбулися суттєві зміни і доповнення. Зокрема, відповідно до Закону України «Про внесення змін до деяких законодавчих актів України щодо посилення охорони i захисту прав на торговельні марки i промислові зразки та боротьби 3 патентними зловживаннями» [53] для відповідності європейському законодавству у профільне національне законодавство у цій сфері були внесені значні зміни, а саме: щодо визначення поняття «промисловий зразок», поділу промислових зразків на два правових режими, строку чинності виключних майнових прав інтелектуальної власності на промисловий зразок, критерій охороноздатності промислового зразка тощо і це доцільно.

Особливість правової охорони промислових зразків у $\mathrm{CC}$, як нині й в Україні, полягає в тому, що вона умовно поділяється на два правові режими. Один регулює відносини щодо охорони зареєстрованих промислових зразків ЄС, другий - незареєстрованих. Можливість отримання правової охорони на промислові зразки без реєстрації була запроваджена спеціально для тих об'єктів права інтелектуальної власності, які мають попит дуже короткий період. Це, як правило, вироби, які швидко морально застарівають, і комерційне життя їх достатньо коротке. 3 цієї причини проходження достатньо тривалих за часом формальностей, які до того ж потребують значних фінансових витрат, пов’язаних з процедурою реєстрації таких промислових зразків, є недоцільним. В той самий час така охорона надає їх власнику більші переваги. Незареєстрованим промисловим зразкам, які стали загальнодоступними на 
території країн-членів ЄС, надається правова охорона без додержання формальностей та сплати мита одночасно в межах Свропейського Союзу [54].

Наразі законодавство України у сфері охорони промислових зразків також містить поняття «зареєстрований промисловий зразок» та «незареєстрований промисловий зразок». Проте у Цивільному кодексі України правова охорона на промисловий зразок не поділяється на два правові режими, а саме: на зареєстрований та незареєстрований промисловий зразок. Вважаємо, що положення профільного законодавства повинно відповідати положенням Цивільного кодексу України.

Для того, щоб продовжити розвиток системи охорони промислової власності в Україні, наразі доцільно створити й прийняти Кодекс України про інтелектуальну власність. Вагомими чинниками для прийняття кодифікованого акту у сфері інтелектуальної власності є: створення в Україні Вищого суду 3 питань інтелектуальної власності; євроінтеграційні процеси в Україні; суперечливі положення, неузгодженні норми, прогалини між профільними законами у сфері інтелектуальної власності та книгою 4 Цивільного кодексу України; завдання створення єдиної системи охорони права інтелектуальної власності, здатної належним чином охороняти та захищати права зацікавлених осіб.

Судові спори щодо охорони та захисту прав інтелектуальної власності $є$ одними з найскладніших для розгляду, оскільки вимагають знання не лише специфічних юридичних аспектів, але й технічних. Тому і суддям, і суб'єктам права інтелектуальної власності було б набагато легше розібратися у цій складній сфері, якби законодавство інтелектуальної власності було систематизовано в одному кодифікованому акті - Кодексі України про інтелектуальну власність. 


\section{SECTION 4. CRIMINAL AND CRIMINAL - EXECUTIVE LAW}

\section{1 Попередження злочинів як ключове завдання сучасного кримінального права}

Слід зазначити, що попередження злочинності як ключове галузеве завдання сучасного кримінального права - це складне комплексне поняття, в якому відображується теорія та практика специфічної діяльності компетентних органів держави, що ставить на меті недопущення скоєння злочинів як шляхом усунення їх причин та умов, так і шляхом переривання злочинних дій на різних стадіях їх скоєння.

Період становлення України як незалежної та самостійної держави призвело до безлічі змін, особливо при цьому варто відзначити процес реформування кримінального, кримінально-процесуального та кримінально-виконавчого законодавства, у тому числі - ухвалення нового Кримінального кодексу України 2001 р., що також потягло за собою низку невирішених проблемних аспектів і законодавчих прогалин.

Зараз в нашій країна спостерігається дуже складна ситуація кримінального характеру, зважаючи на підвищення кількісного рівня злочинності в умовах протистояння зовнішній збройній агресії Російської Федерації та якісну різноманітність самих форм злочинної діяльності.

При цьому концепція сучасного кримінального законодавства виходить 3 тієї важливої методологічної позиції, що попередження злочинності $\epsilon$ об’єктивною потребою суспільства. Головний напрям попередження злочинності - це усунення причин та умов, що іiі породжують і сприяють ¥іi різноманітним проявам. Загалом попередження злочинності являє собою цілеспрямований комплексний процес, що здійснюється державними органами, господарськими i громадськими організаціями, a також громадськими формуваннями і окремими громадянами. Це є завданням всіх гілок державної влади: законодавчої, виконавчої, судової. Значне місце відводиться, крім зазначених вище суб’єктів, правоохоронним органам, для яких запобігання 
злочинності один з основних професійних обов’язків, який потребує не тільки ініціативності, непримиримості, принциповості, творчого підходу, а й високого рівня кримінологічного знання [55].

Відповідно 3 ч. 1 ст. 2 Кримінального кодексу України, підставою кримінальної відповідальності є скоєння особою суспільно небезпечного діяння, яке містить склад злочину, передбачений цим кодексом.

Ніхто не може бути притягнутий до кримінальної відповідальності за один злочин більше ніж один раз. Це положення відповідає ч. 1. ст. 61 Конституції України, відповідно до якої ніхто не може бути двічі притягнутий до юридичної відповідальності одного виду за одне і теж правопорушення [56].

Таким чином, кримінальна відповідальність - це об’єктивне право держави реагувати на скоєний злочин. Така реакція знаходить своє вираження в обвинувальному вироці суду. В зв’язку 3 цим розрізняють матеріальну i процесуальну підставу кримінальної відповідальності. Матеріальною підставою є злочин, а процесуальною - обвинувальний вирок суду. Особа вважається невинною у скоєні злочину і не може бути піддана кримінальному покаранню, поки їі вина не буде доведена в законному порядку і встановлена обвинувальним вироком суду.

У ст. 14. КК України зазначено, що злочином є передбачене кримінальним кодексом суспільно небезпечне винне діяння (дія або бездіяльність), скоєне суб'єктом злочину.

У свою чергу, кримінальне право як галузь права представляє собою сукупність юридичних норм, прийнятих Верховною Радою України, які встановлюють які суспільно небезпечні діяння є злочинами і які покарання застосовуються до осіб, які їх вчинили.

Головною функцією кримінального права являється охорона суспільних відносин. Охоронна функція кримінального права чітко виражена в ст. 1 Кримінального кодексу України, де визначено, що завдання Кримінального кодексу $є$ наступні: охорона від злочинних посягань найбільш важливих соціальних цінностей: прав i свобод людини i громадянина, власності, 
громадського порядку i громадської безпеки, навколишнього середовища, конституційного устрою України, забезпечення миру і безпеки людства, а також запобігання злочинам.

Кримінальне право виконує також регулятивну функцію, яка проявляється в тому, що норми кримінального права, забороняючи вчиняти суспільно небезпечні діяння, в той же час вимагають певної правомірної поведінки. Регулятивна функція кримінально-правових норм відображається в попередженні злочинів та їх недопущенні свідомими громадянами. Але норми кримінального права відносяться до регулятивних, оскільки регулюють поведінку людини в ризикованих ситуаціях. Так, наприклад, існують норма про необхідну оборону, яка виключає відповідальність при правомірному захисті від злочинного посягання, норми про звільнення від кримінальної відповідальності, погашення або зняття судимості тощо [57].

Кримінальний кодекс України $є$ головним правовим джерелом у попередженні злочинності як негативного соціального явища. У ньому закріплені безліч правових норм, які запобігають виникненню кримінальних злочинів. І хоч кримінальне право в сучасних українських умовах залишається одним 3 ключових важелів, які держава використовує у намаганні вплинути на злочинність, але це все одно кардинально не вирішує дану проблему, адже кримінально-правові норми лише несуть так би мовити попереджувальний характер «не вчиняй злочин, тому, що понесеш за це покарання», але ж зовсім не стосуються головних причин скоєння злочинів у суспільстві. При цьому не можна стверджувати, що лише соціальні чинники впливають на скоєння злочинів, адже вчинення злочину - це, перш за все, вольовий та усвідомлений вибір людини, не беручи до уваги ті, злочини, які скоюються при примушуванні до них [58]. Отже, беручи до уваги це положення, слід наголосити на тому, що не лише соціальний, економічний та політичний стан призводить до скоєння злочинів, але й моральні принципи, психічний стан, ставленні людини до життя, також впливають на кількісний рівень злочинності у соціумі. 
Отже, існуюча ситуація, безперечно, потребує реалізації добре продуманої стратегії протидії злочинності, на перший план у якій повинні виходити заходи не тільки кримінально-правового, але і загального запобіжного впливу з метою зменшення кількісних та якісних показників злочинності.

При дослідженні кримінально-правових аспектів попередження, необхідно зазначити і ту обставину, що поняття «попередження злочинності засобами кримінального права» недостатньо чітко визначено в кримінально-правовій літературі. Зокрема, до цього поняття традиційно включають засоби протидії злочинності, які не $є$ попереджувальними у власному розумінні слова, а являють собою засоби утримання осіб від вчинення злочинів. В зв'язку з цим, при розгляді місця та ролі кримінально-правових засобів в попередженні злочинності, на наш погляд, доцільно спиратися на кримінологічне визначення попередження злочинності як системи заходів, спрямованих на усунення та нейтралізацію причин та умов злочинності, переривання злочинної активності на ранніх етапах ï прояву (профілактика, запобігання та переривання злочинів) [59]

Таким чином, можна сформулювати низку практичних рекомендацій в сфері кримінального законодавства та практики його застосування. Наприклад, в частині визначення санкцій кримінально-правових норм необхідно в процесі внесення змін та доповнень до Кримінального кодексу України дотримуватися принципу відповідності між тяжкістю санкції кримінально-правової норми та віднесенням відповідної норми до категорії злочинів, що безпосередньо посягають на права та інтереси фізичних та юридичних осіб, або ж до злочинів 3 подвійною превенцією [60].

В цілому, аналізуючи попередження злочинів кримінально-правовими засобами в сучасних українських реаліях, можна зробити загальний висновок концептуального характеру, що загальну превенцію слід розглядати як ключовий напрям застосування та подальшого стратегічного реформування кримінальноправової галузі, оскільки конкретні цілі при реалізації відповідних заходів кримінально-правового характеру можуть не лише не збігатися, а різнитися між собою, адже заходи кримінально-правового впливу можуть застосовуватися не 
лише до суб'єкта вчинення злочину, а й до неосудної чи малолітньої особи, яка вчинила суспільно небезпечне діяння, передбачене кримінальним законом. Отже, процес застосування конкретних заходів кримінально-правового впливу, виходячи із співвідношення загального й окремого, має власні цілі, оскільки окреме зазвичай набуває своїх особливих ознак (спеціальна превенція), які можуть бути не властиві цілому (загальна превенція). 


\section{2 Напад як форма вчинення злочинів проти осіб та установ, що мають міжнародний захист (Ст. 444 КК України)}

Помітне місце в структурі сучасної злочинності обіймають агресивнонасильницькі посягання, в структурі яких присутні акти фізичної або психічної агресії. Найбільш поширеним з них є напад. Так, зокрема, напад утворює одну 3 форм вчинення злочинів проти осіб та установ, які мають міжнародний захист, кримінальну відповідальність за вчинення яких наразі передбачає ст. 444 Кримінального кодексу (далі - КК) України. Зазначене посягання належить до кримінальних правопорушень проти міжнародного правопорядку, однак його наслідки здатні завдавати шкоди більш важливим об'єктам - аж до міжнародного миру. Новій і новітній історії людства (XX-XXI ст.) добре відомі випадки, коли насильницькі акти, спрямовані проти офіційних представників інших суб'єктів міжнародного права, призводили до масштабних міжнародних конфліктів, які набували різних, аж до глобальних, масштабів. Так, приводом для початку Першої Світової війни став вчинений 28 червня 1914 р. Г. Принципом (членом однієї з таємних сербських організацій, що боролися з пануванням Габсбургів) напад на престолонаслідника Австро-Угорської Імперії ерцгерцога Франца Фердінанда Австрійського, який перебував із офіційним візитом у столиці Боснії місті Сараєво [61]. Переконливою ілюстрацією зв'язку між недоторканністю дипломатичних установ із засадами підтримання міжнародного правопорядку став учинений у м. Тегеран (Іран) 4.11.1979 р. напад радикально налаштованих студентів-ісламістів на посольство США і захоплення його будівлі та всіх членів персоналу посольства (за різними даними - від 66 до 90 осіб). Загарбники захопили 52-х американських дипломатів й висунули до США низку вимог політичного характеру. У відповідь на ці дії президент США Д. Картер негайно видав розпорядження заморозити усі іранські активи у банках США i, не зважаючи на енергетичну кризу, ввести ембарго щодо іранської нафти. Дипломатичні відносини цих держав було розірвано більш ніж як на тридцять років [62]. Унаслідок ужитих міжнародною спільнотою заходів Іран 
SCIENTIFIC APPROACHES IN JURISPRUDENCE

зазнав величезних матеріальних збитків, а в світовій економіці розпочались негативні процеси, пов’язані з ростом цін на нафту.

Аналіз юридичної літератури, в якій розглядається напад як одна 3 форм передбаченого ст. 444 КК України кримінального правопорушення свідчить про очевидну дискусійність проблеми його змісту. Так, М. Хавронюк визначив його як «дії, пов’язані 3 несподіваною агресією, застосуванням насильства над особою, що має міжнародний захист, знищенням майна, яке їй належить або ввірене, а також будь-які інші подібні дії. Поняттям нападу... охоплюється й застосування до відповідної особи насильства, пов’ язаного з умисним заподіяння їй побоїв, легких чи середньої тяжкості тілесних ушкоджень, якщо умисел винного не був спрямований на заподіяння потерпілому смерті...» [63]. Подібним чином міркує й В. Киричко, який розуміє напад як «дії, спрямовані на негайне досягнення злочинного результату за допомогою насильства або створення реальної небезпеки його застосування» [64]. Зазначений автор не виключає поєднання нападу із проникненням у службові, житлові приміщення, знищенням, пошкодженням майна, заподіянням тілесних ушкоджень будь-яким особам. Слід зауважити, що наведені вище наукові позиції розширюють нормативно визначений зміст нападу як форми посягання, передбаченої ст. 444 КК України. У ній законодавець криміналізував лише зазначені дії, спрямовані проти матеріальних об’єктів (службових або житлових приміщень), залишивши поза увагою напади на осіб, які мають міжнародний захист. Зазначений пробіл, безперечно, має бути усунений, але лише приведенням змісту аналізованої форми у відповідність із міжнародними зобов’язаннями України, тобто шляхом внесення доповнень до диспозиції ст. 444 КК України.

Зважаючи на те, що напад як форма посягання, передбаченого ст. 444 КК України, є предметним злочином, правильно інтерпретує його О. Бахуринська, яка пов'язує його 3 протиправним проникненням у службове чи житлове приміщення особи, яка має міжнародний захист, учиненням погромів, пошкодженням, знищенням майна, висуненням вимог тощо[65]. Схоже тлумачення поняття нападу на приміщення осіб, які перебувають під 
міжнародним захистом, знаходимо у виданнях із міжнародного кримінального права [66].

Не погоджуючись із поширеними в літературі варіантами тлумачення змісту нападу як форми передбаченого ст. 444 КК України посягання (зокрема, у зв’язку iз ототожненням в них нападу на приміщення із нападами на особу), С. Мохончук пропонує розуміти його як вчинення несанкціонованого знищення або

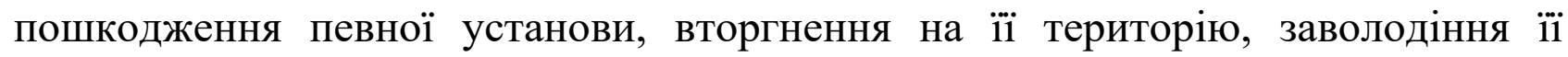
майном або майном особи, котра користується міжнародним захистом, заволодіння дипломатичною поштою[67]. Втім, таке визначення також видається небездоганним, адже лишається незрозумілим, яким чином може бути знищено чи пошкоджено певну установу, чи розглядається як напад заволодіння документами за межами приміщень, про які ідеться в ст. 444 КК України)[68].

Як бачимо, напад фахівці часто розглядають перш за все як акт агресії проти фізичної особи. Слід зазначити, що такий спосіб доктринальної інтерпретації поняття «напад» більш придатний для характеристики злочинів, до структури безпосереднього об’єкта яких входить особа - зокрема, для насильницьких злочинів проти власності. Наприклад, в складі розбою (ст. 187 КК) напад - це умисні дії, спрямовані на негайне вилучення чужого майна шляхом застосування фізичного або психічного насильства, небезпечного для життя або здоров'я особи, яка зазнала нападу [69]. Тому ці висновки є справедливими щодо злочинів, спрямованих проти особи, де насильство (фізичне чи психічне) в сукупності з іншими діями утворює напад. У таких випадках слушною є думка О. Храмцова, що «напад неможливий без застосування до потерпілого фізичного або психічного насильства, або першого і другого одночасно» [70].

Справді, при вчиненні тих же розбоїв досягнення мети (заволодіння чужим майном) практично неможливе без акту агресії, спрямованого проти особи (власника майна, його охоронця чи законного володільця тощо). Однак, за смислом чинної редакції диспозиції ст. 444 КК об’єктом нападів є приміщення, які використовується особою, а не сама особа. Тому названий у ній напад може бути, зокрема, засобом впливу на діяльність осіб, які мають міжнародний захист 
SCIENTIFIC APPROACHES IN JURISPRUDENCE

або на діяльність держав чи організацій, шляхом порушення нормальних умов такої діяльності (наприклад, унаслідок тимчасового припинення роботи міжнародної організації шляхом захоплення їі головного офісу). При цьому вторгнення у приміщення не обов'язково має бути поєднане 3 фізичним насильством або його погрозою щодо тих, хто перебуває в приміщеннях. Якщо, до прикладу, захоплення приміщення міжнародної установи здійснене в час, коли в ньому завідомо для винного немає співробітників, охоронців, технічного персоналу, то фактичного застосування насильства в такому випадку не відбувається. Отже, аналізоване поняття нападу слід пов’язувати передусім 3 протиправним проникненням до приміщень, їх захопленням. При цьому ознака «застосування насильства» не може бути визнана іманентною будь-якому випадку вчинення діяння «напад на службові або житлові приміщення осіб, що мають міжнародний захист». Більш точно, на нашу думку, вести мову про ознаку «готовність застосування насильства» як ознаку цього діяння.

Особливості нападу, який, за смислом ст. 444 КК України, спрямований на певні об’єкти матеріального світу, потребують обговорити питання про включення до нього використання винним певних знарядь або засобів (наприклад, здійснення пострілу у вікно приміщення, спрямування автомобіля в стіну такого приміщення тощо). У теорії кримінального права з питання щодо об'єктивної межі дії у злочинах, пов’язаних із таким механізмом посягання, було висловлено різні погляди. Так, на думку одних науковців дія особи, котра має кримінально-правове значення, охоплює не лише рухи тіла людини, а й ті сили, знаряддя, механізми, інші обставини та закономірності, які вона використовує для заподіяння суспільно небезпечного результату. Відповідно, за цього підходу вважається, що дія виконана після того, як було реалізовано той потенціал, який мало знаряддя, використане винним. Водночас, інші фахівці цьому заперечують. Характерним є висловлювання $з$ цього приводу В. Кудрявцева, який писав, що «злочинна дія закінчується тими рухами, шляхом яких людина впливає на визначені сили та засоби..., подальша ж робота механізмів, дія сил природи або поведінка третіх осіб, використані злочинцем, становлять продовження 
SCIENTIFIC APPROACHES IN JURISPRUDENCE

об'єктивної сторони злочину, яке часто вже не залежить від волі суб'єкта» [71]. Проміжну (i, на нашу думку, найбільш вдалу) позицію 3 цього питання обгрунтував М. Грінберг, на думку якого для його вирішення найсуттєвішим моментом $\epsilon$ наявність контролю людини за розпочатим ним ходом подій або ж втрата такого контролю. У першому випадку сили природи діють під контролем людини та не відрізняються, таким чином, від іiї власних дій, у другому - дія людини закінчується тим порухом тіла, яким людина відкриває шлях для дії сил природи (наприклад, штовхнувши жертву під потяг, натиснувши на спусковий гачок пістолету тощо) [72]. Тому використання винною особою певних знарядь чи засобів для нападу на службові чи житлові приміщення осіб, що користуються міжнародним захистом, є частиною цієї дії, якщо нападник зберігає контроль за ними (наприклад, управляє автомобілем, який руйнує ворота посольства).

За конструкцією об'єктивної сторони всі форми передбачених ст. 444 КК України злочинів проти осіб та установ, що мають міжнародний захист, мають формальні склади. Тобто, для ii наявності не виникає необхідності у встановленні суспільно небезпечних наслідків вчиненого посягання та причинного зв'язку між діяння та шкодою, що може настати. Водночас, це не означає, що шкода не матиме значення для кримінальної відповідальності за аналізовані злочини. Наслідки можуть не належати до об'єктивної сторони складу злочину, але ж, як реальна подія, кожен злочин завжди містить шкоду або реальну можливість заподіяння шкоди. Тому за умови фактичного настання негативних змін у будь-яких охоронюваних кримінальним законом об'єктах при вчиненні злочинів проти осіб та установ, що мають міжнародний захист (наприклад, пошкодження майна при нападі на приміщення установи, реакції суб'єкта міжнародного права у виді початку міжнародного конфлікту тощо) вони мають бути враховані при індивідуалізації кримінальної відповідальності винного. 


\section{SECTION 5. EUROPEAN LAW}

\section{1 Європейські механізми захисту прав людини}

В сучасному світі правам та свободам людини приділяється значна увага, прийнято ряд міжнародно-правових актів в цій сфері, але досі вони потребують захисту як з боку держави, так і з боку міжнародних та регіональних організацій.

Провідними в цьому плані виступають європейські країни, які і займалися розробкою відповідних правових актів та установ, створили потужні механізми захисту прав людини, серед яких особливої уваги заслуговує Європейський суд 3 прав людини.

Європейський континент також вирізняється прогресивними формами співробітництва, яке було започатковано зі створення Європейського об’єднання вугілля та сталі у 1951 році і переросло у потужну наднаціональну організацію Європейський Союз. І хоча, від самого початку, захист прав людини не ставився ціллю цієї організації, але з прийняттям Маастрихтської угоди 1992 року майбутнє членство в даній організації стало залежати від участі країникандидата на вступ в Європейській конвенції про захист прав людини та основних свобод (далі - СКПЛ), ухваленої Радою Європи в 1950 р. (ст. 6 розділ I). 3 цього моменту захист прав людини проголошено в якості одного з основних напрямів політики і діяльності ЄС. Це обумовило необхідність формування ефективної системи охорони прав особи, яка складається 3 судових та позасудових способів захисту.

В силу своєї наднаціональності ЄС має свої особливості, які стосуються і механізмів захисту прав людини. Зокрема, довгий час в рамках Союзу був відсутній єдиний документ в цій сфері. Вже згадана конвенція не могла зіграти цю роль, оскільки не відноситься до джерел права $\mathrm{CC}$ і таким чином не $\epsilon$ обов'язковою для його інститутів. Значним кроком в цьому напряму стало ухвалення 7 грудня 2000 року Хартії основних прав СС. 
SCIENTIFIC APPROACHES IN JURISPRUDENCE

Слід зазначити, що цей документ не передбачав його підписання та ратифікації державами, не був міжнародним договором і не мав юридично обов'язкового характеру. Хартія приймалась як політичний документ, на підставі якого країни створюють уніфіковані національні норми та право Свросоюзу Але зі вступом в силу Лісабонського договору у 2009 р., Хартія, як його невід’ємна складова, набула юридично обов'язкового характеру. Отже, Свросоюз отримав правовий документ, який містить наразі найбільш повний перелік громадянських, політичних, економічних, соціальних та культурних прав осіб (резидентів Свросоюзу), які напрацьовані світовим співтовариством [73].

У зв'язку з цим слід зазначити, що не дивлячись на посилання на СКПЛ як одну з умов приєднання, ï учасницями є лише держави-члени $€ C$, а не власне сам Союз. Тому Конвенція 1950 року не становить частину права ЄС. Хоча питання щодо приєднання СС до Конвенції ставилось ще у 1996 році, але Суд СС у своєму Висновку 2/94 підкреслив, що Союз не має компетенції для приєднання до ЄКПЛ. Не полишаючи цю ідею, у новій редакції ст. 6 Договору про ЄС, яка набула чинності на підставі Лісабонського договору у 2009 р., а саме у констатації того, що основоположні права, гарантовані СКПЛ і які випливають iз конституційних традицій держав-членів, є загальними принципи права $\mathrm{CC}$, а також ч. 2 ст. 6: «Союз приєднується до ЄКПЛ. Це приєднання не впливає на повноваження Союзу, визначені Договором» [74].

Але в 2014 році Суд $С$ С повторно постановив Висновок про несумісність проекту Угоди про приєднання до ЄКПЛ із законодавством ЄС. У початку свого висновку Суд підкреслив відсутність правової основи для приєднання ЄС до ЄКПЛ. Суд зазначив, що в результаті цього приєднання, ЄКПЛ, як і будь-який інший міжнародний договір, укладений $€ C$, буде обов'язковим для інститутів ЄС та його держав-членів, і буде становити невід'ємну частину права ЄС. У цьому разі $Є С$, так само як інші договірні сторони, підлягатиме зовнішньому контролю задля забезпечення дотримання прав і свобод, передбачених ЄКПЛ. Таким чином, СС та його інститути будуть підлягати зовнішнім механізмам контролю, передбачених Конвенцією, i, зокрема, з боку ССПЛ. Суд зазначив, що 
SCIENTIFIC APPROACHES IN JURISPRUDENCE

є неприпустимою ситуацію, коли інтерпретація ЄСПЛ буде обов'язковою для ЄC та всіх його інститутів, в той час, коли, інтерпретація прав, визначених в ЄКПЛ, Судом ЄС не буде обов'язковою для ЄСПЛ. Суд СС констатував, що ЄКПЛ надає державам-учасницям можливість встановлювати вищі стандарти захисту прав, закріплених Конвенцією. Сам Суд ЄС у рішенні по справі Melloni зазначив, що держави-члени СС не можуть встановлювати вищі стандарти ніж ті, що встановлені у Хартії про основоположні права СС, якщо ЄС повністю гармонізував відповідне право.

Далі у Висновку Суд нагадує, що ст. 344 Договору про функціонування СС передбачає, що держави-члени зобов'язуються не представляти спір, що стосується тлумачення або застосування установчих договорів, до будь-якого іншого методу врегулювання крім передбачених в установчих договорах ЄС. Отже, Суд СС має виключну юрисдикцію щодо будь-яких спорів між державами-членами та державами-членами та ЄС щодо дотримання ЄКПЛ. Відповідно до Проекту Угоди існує можливість, що ЄС або держави-члени можуть подати скаргу до ЄСПЛ стосовно ймовірного порушення Конвенції державою-членом ЄС або самим ЄС. Ця можливість повністю суперечить положенням Договору про функціонування СС у контексті права СС. Проект міг би закріпити виключення з юрисдикції ЄСПЛ щодо спорів між державамичленами ЄС або між останніми та самим ЄС стосовно застосування ЄКПЛ у контексті права СС, але такого не відбулося [75]. Переговорний процес з цього приводу планується відновити у березні 2021 року.

Таким чином, незважаючи на той факт, що зміни, внесені до установчих документів ЄС Лісабонським договором 2007 р., передбачають обов’язок ЄС приєднатися до системи захисту прав людини на основі ЄКПЛ, сьогодні власне Хартія СС є джерелом стандартів захисту прав людини для усіх органів та інституцій ЄС [76].

Слід зазначити, що положення Хартії мають юридичну силу лише у тих сферах, які регулюються правом СС. Що стосується, наприклад шлюбносімейних відносин, які не регулюються правом СС, то тут Хартія не має для 
SCIENTIFIC APPROACHES IN JURISPRUDENCE

держав-членів обов'язкової сили, а в разі порушення прав в цих сферах, особа має звертатися до національних нормативно-правових актів або ЄКПЛ.

Як зазначив К.В. Ентін, для Суду $\mathrm{CC}$ - органу, який послідовно забезпечує втілення принципу пріоритету права СС щодо національних правопорядків держав-членів цього формування, першочергового значення набула саме Хартія ЄC, a не ЄКПЛ, попри те, що остання визнана ЄС одним із загальних принципів його правової системи, які (принципи) теж є джерелами права ЄС. Адже відповідно до п. 3 ст. 6 Договору про ЄС (один із установчих актів $Є С$, змінений Лісабонським договором) основоположні права, в тому вигляді, в якому вони закріплені в ЄКПЛ i випливають із спільних для держав-членів ЄС конституційних традицій, визнаються загальними принципами права ЄС (що ставить їх в ієрархії джерел права ЄС на друге місце після його установчих договорів) [77].

Отже, саме Суд ЄС є основним судовим способом захисту прав людини i громадянина в рамках Європейського Союзу, але лише з боку інституцій останнього. Оскільки Хартія є обов'язковою лише для інститутів ЄС при прийнятті відповідних правових актів, а фізичні та юридичні особи не можуть оскаржувати акти інститутів Союзу на предмет порушення останніми прав та свобод, закріплених у Хартії ЄС.

Звісно не слід забувати про національну систему правосуддя держав-членів, яка тривалий час була головною у сфері захисту прав громадян ЄС. Особливість їхньої діяльності полягає в тому, що суди держав-членів Союзу мають керуватися як нормами національного, міжнародного права, так і права СС. 3 цього приводу Суд СС зайняв позицію, згідно з якою дотримання основних прав і свобод, які закріплені в Конвенції і являють собою конституційний принцип, загальний для всіх держав-членів, підлягає дотриманню і в праві Співтовариства

Також Суд СС переглянув раніше висловлену власну позицію щодо відсутності у нього права розглядати справи про дотримання прав людини державою-членом, якщо дане питання не пов'язане з дотриманням державоючленом зобов'язань згідно з установчим договором, визнавши за собою право 
розглядати справи, які пов'язані $з$ дотриманням державами-членами основних прав і свобод, закріплених Конвенцією, якщо вони мають тісний зв'язок 3 правами економічного характеру, гарантованими установчими договорами [78].

Повертаючись до способів захисту прав людини в СС слід зазначити, що до позасудових інститутів можна віднести розгалужений організаційний механізм який складається з таких органів: Омбудсмен Свропейського Союзу, Агентство основних прав Свропейського Союзу, інститути Свропейського Союзу (Комісія ЄC та Рада (С), Європейський контролер із захисту даних, Загальний контрольний орган у межах Сврополу. Але особливість діяльності цих органів полягає в тому, що вони захищають права особи лише від зазіхань з боку інститутів Союзу, а не країн-членів, таким чином звернення до ЄСПЛ досі актуальні.

Сфера діяльності цих механізмів окрема в кожного з органів. Так, фізичні та юридичні особи можуть звертатися лише до Омбудсмана, органи ЄС звертаються до Агентства основних прав Європейського Союзу, а Рада ЄС приймає лише звернення держав-учасниць.

Якщо розглядати ці механізми 3 точки зору інституційної ієрархії, то провідне місце відводиться Раді ЄС та Комісії СС.

Рада $\mathrm{EC}$, як один із законодавчих інститутів Союзу, є досить ефективним інструментом захисту прав осіб, оскільки містить функції дізнання ,ухвалення рішення та притягнення до відповідальності. Так, на вимогу однієї третини країнучасниць або Комісії, одразу після ухвалення ствердного висновку Парламенту ЄC Рада ЄC має можливість одноголосно визнати порушення будь-якою країною-учасницею принципів, зазначених у ст. 2 Конвенції. Ухваленню подібного висновку передує виклик представників такої країни для пред’явлення зауважень та рекомендацій стосовно наявної проблеми.

Якщо порушення було визначено у висновку Парламенту $\mathrm{CC}$, Рада $\mathrm{CC}$ кваліфікованою більшістю має ухвалити рішення стосовно обмеження права визначеної у висновку країни-учасниці, таке положення міститься у Договорі про створення Європейського союзу, зокрема призупинити право на участь у 
голосуванні представника уряду зазначеної країни-учасниці на сесії Ради ЄС. Ухвалюючи таке рішення, Рада ЄС оцінює ймовірні наслідки цього обмеження права стосовно прав фізичних та юридичних осіб [79].

Комісія Свропейського Союзу, як виконавчий орган, стежить за дотриманням правил СС. Вона може виконувати функцію дізнання стосовно факту вчинення протиправних дій і як наслідок - застосовувати штрафні санкції. Об’єктом протиправних дій є будь-яке порушення країною-учасницею вимог, висунутих до неї установчими нормативно-правовими актами Європейського Союзу, включно з протиправними діями, вчиненими в сфері прав людини. Як зазначає Я.І. Коваленко, наголошується саме на факті вчинення протиправних дій, при цьому до уваги не беруться передумови такого правопорушення. Головною перевагою процедури дізнання Комісії $\epsilon$ право на звернення осіб (фізичних або юридичних) до Комісії стосовно протиправної дії, вчиненої країною-учасницею в межах проведеного розслідування. Таким чином, Комісія ЄС поєднує в собі інформаційну та представницьку функції й функції, пов’язані 3 дізнанням та ухваленням рішень. Відсутність можливості у цієї Комісії застосувати санкції покривається можливістю подати позов до Суду Європейського Союзу стосовно окремої країни-порушниці. Своїм рішенням Суд має право зобов’язати окрему країну-порушницю припинити протиправні дії, відновити порушене право тощо [80].

Цікавим є інститут Омбудсмена $\mathrm{CC}$, який був запроваджений Договором про Європейський Союз і набув самостійний юридичний статус. Європейський омбудсман уповноважений одержувати від кожного громадянина Союзу або від кожної фізичної або юридичної особи, що проживає або має свою юридичну адресу в державі-члені, скарги щодо випадків порушення порядку управління в діяльності інститутів, органів або установ Союзу, крім Суду Свропейського Союзу при здійсненні ним своїх юрисдикційних функцій. Він розслідує ці скарги й складає по них доповіді. Омбудсмен за своєю власною ініціативою або на підставі скарг, представлених йому безпосередньо або через члена Європейського парламенту, проводить розслідування, які вважає 
SCIENTIFIC APPROACHES IN JURISPRUDENCE

обгрунтованими, якщо тільки стверджуванні факти не $є$ або не були об'єктом судової процедури. Особа, що звернулася зі скаргою, інформується про результат цих розслідувань. Обмудсмен щорічно представляє Європейському парламенту звіт про результати своїх розслідувань [81]. Таким чином, інститут Омбудсмена ЄС прирівнюється до національних омбудсменів, проте вадою такого механізму є неможливість прийняття обов'язкових рішень.

Що стосується Агентства 3 фундаментальних прав Свропейського Союзу, створеного у 2007 році, то воно виступає наділеним спеціальними повноваженнями органом, метою якого є підвищення ступеню захисту прав особи в $€ С$. Головним його завданням $є$ забезпечення інститутам $€ C$ і країнамучасницям допомоги в ухваленні рішень стосовно розвитку функцій, необхідних для гарантування фундаментальних прав людини. Воно виконує спрямовуючу й інформативну функції, але не має права розглядати персональні звернення чи ухвалювати рішення, наслідком яких є їх неухильне виконання. Проте воно посідає важливе місце у створенні нормативної бази, яка поєднує основні принципи прав людини та злагоджений механізм захисту прав людини в межах ЄC. Але, як і інститут Омбудсмена, Агентство не володіє повноваженнями стосовно ухвалення рішень, які мають загальнообов'язкову правову дію [80].

Слід також додати ще один механізм захисту прав людини, який існує в рамках Союзу завдяки впровадженню громадянства ЄС Маастрихтським договором про Європейський Союз. Це передбачене ст. 23 Консолідованої версії Договору про функціонування Свропейського Союзу право на звернення до органів Європейського співтовариства право громадянина Союзу на території третьої країни, де не представлена держава-член, громадянином якої віє є, на захист дипломатичних представництв і консульств будь-якої держави-члена на таких самих умовах, що і громадяни цієї держави.

Передбачене ст. 24 право кожного громадянина СС звертатися до Європейського Парламенту, до Омбудсмена та будь-якої установи, органу, служби або агенції Союзу. I право громадянської (законодавчої) ініціативи, що 
дає можливість подавати та впливати на зміст нормативних актів, що у перспективі стають частиною національного права держав-членів [82].

Таким чином, європейський механізм захист прав людини, який функціонує в рамках $\mathrm{CC}$ не може розглядатися як такий, що має цілісну структуру, оскільки паралельно існують національні системи захисту прав і на рівні Свросоюзу. Наявні правові підстави захисту прав людини в СС, серед яких провідну роль відіграє Хартія про основні права 2000 р., і інституційні механізми створюють ефективну систему захисту прав від зловживань з боку інституцій Союзу. Проте вони вимагають вдосконалення, оскільки залишається відкритим питання приєднання ЄС до ЄКПЛ. 


\section{1 Особливості застосування деяких законодавчих актів України в інвестиційній та податковій галузях до проектів міжнародних валютних (фінансових) організацій}

Україна за часів незалежності досить активно співробітничає 3 міжнародними валютними (фінансовими) організаціями, а саме з МВФ, групою Світового банку, СБРР, СІБ та ін. Ці організації надають нашій країні кредити для реалізації проектів в різних галузях економіки та суспільного життя. До здійснення такої співпраці залучається низка органів державної влади, насамперед, Міністерство фінансів України, а також інші міністерства та відомства, як головні розпорядники бюджетних коштів. Варто зазначити, що в процесі реалізації проектів міжнародних валютних (фінансових) організацій на території України, перед органами державної влади та іншими розпорядниками бюджетних коштів постає низка конкретних практичних питань, пов'язаних із застосуванням положень національного законодавства України до таких проектів, в тому числі в інвестиційній та податковій галузях. Зокрема, наприклад, питання стосовно того, чи можна вважати інвестиціями за законодавством України, кошти в іноземній валюті, які надаються міжнародними валютними (фінансовими) організаціями на конкретні проекти, а отже чи підпадає їхня діяльність на території України під категорію «інвестиційна діяльність» та під відповідний режим оподаткування. Тобто, чи будуть регулюватися відносини 3 міжнародними валютними (фінансовими) організаціями щодо реалізації окремих проектів на території України нормами національного інвестиційного та податкового законодавства, або положеннями відповідного міжнародного договору.

Питання, пов'язані 3 інвестиціями, інвестиційними процесами та міжнародною інвестиційною діяльністю, досліджували такі науковці як Б. В. Губський, Д. Г. Лук’яненко, О. М. Мозговий, А. А. Пересада, Б. М. Щукін та ін. Основи інвестиційного права України та інших країн досліджували вчені- 
правники, зокрема О. М. Вінник, В. В. Гущін, А. В. Омельченко, І. 3. Фархутдінов, В. Д. Чернадчук, Р. Б. Шишка та ін. Аналіз проблем, пов'язаних 3 фінансовим та податковим правом, здійснювали такі відомі науковці як С. О. Алісов, Л. К. Воронова, Е. С. Дмитренко, С. Т. Кадькаленко, М. П. Кучерявенко, О. П. Орлюк, П. С. Пацурківський, Н. Ю. Пришва, Л. А. Савченко, Н. С. Хатнюк, Н. І. Хімічева та ін. Однак, деякі практичні проблеми щодо застосування окремих законодавчих актів до проектів міжнародних валютних (фінансових) організацій залишились поза наукових досліджень.

Як вважає Р. Б. Шишка предметом інвестиційного права є майнові та організаційні правовідносини, які виникають у процесі інвестиційної діяльності та реалізації інвестицій [83].

Водночас В. В. Гущін зазначає, що предмет інвестиційного права охоплює суспільні відносини:

- пов'язані з розміщенням на території держави фінансових коштів, іншого майна (як рухомого, так і нерухомого, не вилученого із цивільного обороту), включаючи майнові та особисті немайнові права (наприклад, авторське, патентне право), що інвестуються в економіку. До цієї групи також належать відносини зі створення юридичних осіб за участю іноземних інвесторів, а також відносини зі створення філій і представництв іноземних юридичних осіб на території держави;

- щодо контролю над допуском, створенням і діяльністю на території держави іноземних інвесторів та утворених ними юридичних осіб;

- пов'язані зі створенням на території держави необхідного інвестиційного клімату (режиму) з метою залучення іноземних інвестицій в економіку країни, включаючи надання державою гарантій і пільг іноземним інвесторам при здійсненні ними інвестиційної діяльності в рамках чинного законодавства;

- пов'язані з притягненням до відповідальності за інвестиційну діяльність, що суперечить законодавству [84].

Отже, для розуміння предмета регулювання інвестиційного права та відносин, які підпадають під сферу дії національного податкового законодавства 
SCIENTIFIC APPROACHES IN JURISPRUDENCE

в інвестиційній галузі, важливого значення набуває визначення таких базових категорій як: «інвестор», «інвестиції», «іноземні інвестиції», «інвестиційна діяльність» тощо.

На думку I. 3. Фархутдінова під інвесторами слід розуміти суб’єктів інвестиційного права, які здійснюють вкладання власних, позичених або залучених коштів у формі інвестицій, та їхнє цільове використання. Так, інвесторами можуть бути:

- органи, уповноважені управляти державним та муніціпальним майном або майновими правами;

- громадяни, підприємства, підприємницькі об’єднання та інші юридичні особи;

- іноземні юридичні та фізичні особи, держава та міжнародні організації [85].

При цьому інвестори можуть виступати в ролі вкладників, замовників, кредиторів, покупців, а також виконувати функцію будь-якого іншого учасника інвестиційної діяльності [85].

Фактично аналогічної позиції дотримується і В. В. Гущін, який зазначає, що інвесторами можуть бути органи, уповноважені управляти державним та муніціпальним майном або майновими правами, юридичні особи всіх форм власності, міжнародні організації та іноземні юридичні особи, фізичні особи резиденти та нерезиденти [84].

Розкриваючи зміст інвестиційної діяльності, I. 3. Фархутдінов відзначає, що вона може бути одним з видів підприємництва [85]. А характерними рисами інвестиційної діяльності є:

- володіння матеріальними та нематеріальними цінностями на певній правовій основі (титулі);

- самостійність та ініціатива при прийнятті рішення про їх вкладення в об’єкти підприємницької діяльності та інших видів діяльності;

- надання цінностям, що вкладаються статусу інвестицій [85]. 
Але при цьому варто зазначити, що, як відомо, підприємницька діяльність не належить до функцій та основних видів діяльності міжнародних валютних (фінансових) організацій. Тобто, на нашу думку, діяльність міжнародних валютних (фінансових) організацій щодо надання кредитів (грантів та/або іншої допомоги) для реалізації відповідних проектів на території певної країни за цими ознаками не може підпадати під категорію «інвестиційна діяльність». Крім цього, зауважимо, що науковці також виділяють міжнародну інвестиційну діяльність [86], яку можна розглядати як один з видів міжнародної економічної діяльності.

Суб’єктами інвестиційної діяльності, як вважає I. 3. Фархутдінов, можуть бути фізичні та юридичні особи, іноземні громадяни та юридичні особи, особи без громадянства, а також держави та міжнародні організації [85].

Під інвестицією В. В. Гущін розуміє спосіб розміщення капіталу, який має забезпечити збереження або зростання вартості капіталу та (або) принести позитивну величину доходу; іншими словами, це будь-який інструмент, в який можна вкласти кошти, розраховуючи зберегти або примножити їхню вартість і (або) забезпечити позитивну величину доходу [84].

Розглядаючи питання, пов'язані 3 інвестиційною діяльністю $\mathrm{y}$ міжнародному торговому обороті, О. В. Київець та В. О. Голубєва зазначають, що інвестиції - це будь-який вид майна, який можуть передавати юридичні та фізичні особи для його відповідного вкладення (інвестування) однією державою в економіку іншої [87]. Водночас до категорії «іноземні інвестори» вони відносять суб' єктів, які здійснюють інвестиційну діяльність на території країни, резидентами якої вони не $\epsilon$. Так, іноземними інвесторами можуть бути юридичні й фізичні особи, іноземні держави, міжнародні урядові та неурядові організації [87].

Спеціальне законодавство України дає визначення таких категорій як: «інвестиції», «іноземні інвестиції», «інвестиційний прибуток». Так, згідно 3 підпунктом 14.1 .81 ст. 14 Податкового кодексу України інвестиції - це господарські операції, які передбачають придбання основних засобів, 
нематеріальних активів, корпоративних прав та/або цінних паперів в обмін на кошти або майно [88]. А за ч. 1. ст. 1 Закону України «Про інвестиційну діяльність» інвестиціями є всі види майнових та інтелектуальних цінностей, що вкладаються в об'єкти підприємницької та інших видів діяльності, в результаті якої створюється прибуток (доход) та/або досягається соціальний та екологічний ефект [89]. При цьому варто зазначити, що реалізуючи проекти на території України, міжнародні валютні (фінансові) організації зазвичай не мають на меті придбання основних засобів, нематеріальних активів, корпоративних прав та/або цінних паперів, та не завжди вкладають кошти в об'єкти підприємницької діяльності. Тобто мова йде здебільшого про фінансування об'єктів соціальної інфраструктури, діяльність яких спрямована не на створення прибутку, а на досягнення соціального ефекту. Отже, 3 нашої точки зору, кошти, які вкладаються в проекти міжнародних валютних (фінансових) організацій, що реалізуються на території України, не можна, в чистому вигляді розглядати як інвестиції за національним законодавством нашої держави.

У такому вигляді з метою оподаткування не можна вважати інвестиційним доходом, дохід отриманий міжнародними валютними (фінансовими) організаціями від реалізації проектів на території України. Так, згідно підпункту 14.1.81-1 Податкового кодексу України інвестиційний прибуток - це дохід у вигляді позитивної різниці між доходом, отриманим платником податку від проведення операцій 3 цінними паперами 3 урахуванням курсової різниці, деривативами та корпоративними правами, випущеними в інших, ніж цінні папери, формах, та витратами на придбання таких інвестиційних активів [88].

Як зазначено в абз. 2 преамбули Закону України «Про інвестиційну діяльність» від 18.09.1991 р. № 1560-XII він спрямований на забезпечення рівного захисту прав, інтересів і майна суб'єктів інвестиційної діяльності незалежно від форм власності, а також на ефективне інвестування економіки України, розвитку міжнародного економічного співробітництва та інтеграції [89]. 
Відповідно до ч. 1 ст. 2 Закону України «Про інвестиційну діяльність» від 18.09.1991 р. № 1560-ХІІ інвестиційною діяльністю є сукупність практичних дій громадян, юридичних осіб і держави щодо реалізації інвестицій [89]. Отже практичні дії міжнародних валютних (фінансових) організацій щодо реалізації інвестицій не охоплюються поняттям інвестиційної діяльності за цим Законом. Хоча, варто зауважити, що міжнародні валютні (фінансові) організації мають статус юридичної особи.

Також відповідно до ч. 1. ст. 5 цього Закону суб'єктами (інвесторами і учасниками) інвестиційної діяльності можуть бути громадяни i юридичні особи України та іноземних держав, а також держави [89]. Таким чином, згідно цього Закону міжнародні валютні (фінансові) організації в якості суб'єктів інвестиційної діяльності не розглядаються. До того ж ці організації згідно ч.1, ч. 2 та ч. 3 ст. 5 Закону не підпадають під категорію ні інвесторів, ні учасників інвестиційної діяльності, оскільки інвестори - це суб'єкти інвестиційної діяльності, які приймають рішення про вкладення власних, позичкових і залучених майнових та інтелектуальних цінностей в об'єкти інвестування (ч. 2 ст. 5) [89]. А учасниками інвестиційної діяльності можуть бути громадяни та юридичні особи України, інших держав, які забезпечують реалізацію інвестицій як виконавці замовлень або на підставі доручення інвестора (ч. 3 ст.5) [89].

Таким чином, враховуючи, що міжнародні валютні (фінансові) організації згідно цього Закону не є суб'єктами інвестиційної діяльності, його положення не можуть безпосередньо на них розповсюджуватися і вони не можуть напряму підпадати під його сферу дії. Водночас кошти, що надаються міжнародними валютними (фінансовими) організаціями на реалізацію проектів в Україні, можуть бути використані у формі державного інвестування державних інвестиційних проектів. А згідно ч. 6. ст. 2 цього Закону державне інвестування державних інвестиційних проектів 3 використанням державних капітальних вкладень та/або кредитів (позик), залучених державою або під державні гарантії, здійснюється відповідно до вимог бюджетного законодавства [89]. 
Також для цілей оподаткування в підпункті 14.1.83 Податкового кодексу України визначено, що термін «інвестор» вживається у значенні, наведеному в Законі України «Про угоди про розподіл продукції». Отже, інвестор (інвестори) - це громадянин України, іноземець, особа без громадянства, юридична особа України або іншої держави, об'єднання юридичних осіб, створене в Україні чи за іiі межами, особи, які діють окремо чи спільно, що має (мають) відповідні фінансово-економічні та технічні можливості або відповідну кваліфікацію для користування надрами та визначений переможцем (переможцями) конкурсу; особа, визначена абзацом п'ятнадцятим частини першої ст. 7 цього Закону, у разі укладення угоди за участю такої особи; особа, яка набула прав та обов'язків, визначених угодою про розподіл продукції, в результаті передачі прав та обов'язків відповідно до ст. 26 цього Закону [90]. Тобто, міжнародні валютні (фінансові) організації не підпадають під категорію інвесторів і за Податковим кодексом України.

Крім цього, відповідно до ст. 22 Закону України «Про інвестиційну діяльність», якщо міжнародним договором України встановлено інші правила, ніж ті, що містяться в законодавстві про інвестиційну діяльність України, то застосовуються правила міжнародного договору [89]. Це положення відповідає ч. 2 ст. 19 Закону України «Про міжнародні договори України», якщо міжнародним договором України, який набрав чинності в установленому порядку, встановлено інші правила, ніж ті, що передбачені у відповідному акті законодавства України, то застосовуються правила міжнародного договору [91].

3 іншого боку, за ч. 1 ст. 1 Закону України «Про режим іноземного інвестування» міжнародні урядові та неурядові організації можуть розглядатися як іноземні інвестори, тобто суб'єкти, які провадять інвестиційну діяльність на території України [92]. Цей Закон в ч. 2 ст. 1 дає визначення іноземної інвестиції, під якою розуміють цінності, що вкладаються іноземними інвесторами в об'єкти інвестиційної діяльності відповідно до законодавства України 3 метою отримання прибутку або досягнення соціального ефекту [92]. А відповідно до 
SCIENTIFIC APPROACHES IN JURISPRUDENCE

ст. 6 цього Закону відносини, пов'язані з іноземними інвестиціями в Україні, регулюються цим Законом, іншими законодавчими актами та міжнародними договорами України. Якщо міжнародним договором України встановлені інші правила, ніж ті, що передбачені законодавством України про іноземні інвестиції, застосовуються правила міжнародного договору [92]. Водночас у ст. 7 цього Закону зазначається, що для іноземних інвесторів на території України встановлюється національний режим інвестиційної та іншої господарської діяльності, за винятками, передбаченими законодавством України та міжнародними договорами України [92]. Отже, їхня діяльність буде підпадати під сферу дії бюджетного, податкового, інвестиційного та іншого законодавства України, за винятками, передбаченими законодавством України та міжнародними договорами України.

Таким чином, відносини, пов'язані 3 міжнародними валютними (фінансовими) організаціями щодо реалізації окремих проектів на території України, регулюються не тільки нормами національного інвестиційного, податкового та іншого законодавства, а, в першу чергу, положеннями міжнародних договорів. Зокрема, положеннями міжнародного договору, укладеного 3 тією чи іншою міжнародною валютною (фінансовою) організацією, які матимуть пріоритет над нормами національного законодавства у випадку їх суперечності.

3 нашої точки зору, варто узгодити зміст законодавчих актів України в інвестиційній галузі щодо діяльності міжнародних валютних (фінансових) організацій на території нашої країни із реалізації відповідних проектів. 


\section{SECTION 7. HISTORY AND PROSPECTS OF DEVELOPMENT OF LOCAL SELF-GOVERNMENT}

\subsection{Directions of improvement of the legal regulation of the system of regulations of local self-governing authorities and officials in Ukraine at the present stage}

Processes of decentralization and strengthening of local self-government, doctrinal recognition and constitutional consolidation of its independence, including in the field of rule-making naturally lead to an increase in the share of laws and regulations of local self-government in the general system of national legislation and formation of a separate subsystem of laws and regulations of local self-government. Own rule-making activities of local self-governing authorities and officials objectively determines originality of the system of acts of local self-government in each administrative-territorial unit.

Improvement of local self-government at the present stage of its development is an important component of the process of reformation of the system of public power in Ukraine. Further process of its reformation requires adoption of a number of new legislative acts and relevant amendments to the current ones, starting with amendments to the Constitution of Ukraine in terms of decentralization. However, such improvement will be incomplete and ineffective if reforms of the regulatory base do not reach the municipal level.

During 1997-2016, domestic local self-governing authorities and officials created basic and socially oriented laws defining the main directions of functioning of the local self-government system on the implementation of the provisions of the Constitution of Ukraine and the Law of Ukraine "On Local Self-Government in Ukraine" and really influencing positive changes in the situation in territorial communities. Today, a new group of laws in the national legal system has been formed - laws and regulations of local self-government playing an increasingly important role in the mechanism of legal regulation of public relations in the country, acting as the main mean of the exercise of public power by the subjects of local self-government in the territory under their 
jurisdiction. With their help, many questions of local value are solved, comprehensive economic and social development of the corresponding territory is ensured.

However, formation and improvement of a system of laws and regulations of local self-government often occurs as a reaction of the relevant subjects (deputies and municipal employees) to the direct requirements of the legislation in force. In the conditions of decentralization local self-governing authorities and officials should show more and more independence and initiative in the resolution of issues of local value, including in the rule-making form. Modern development of local selfgovernment, formation of its bodies as separate from public authorities entitled to independently carry out rule-making within the statutory competence requires introduction of new approaches in the regulation of the rule-making process at various levels of local government, new scientific concepts and categories expanding the notion of rule-making of local self-governing authorities and officials as a special legal form of their activity.

In addition, the current tendency to increase the total number of laws of local selfgovernment leads to conflicts, problems in the implementation of legal rules in the law enforcement practice, a large number of editorial and technical errors. On the other hand, despite their number, regulations of local self-government do not cover all necessary aspects of legal regulation creating a number of gaps. There are still no laws and regulations on a number of most important issues of local value, which complicates or even makes it impossible for legal entities and individuals to exercise their rights and legitimate interests. Systemic links between regulations of different subjects of local self-government are not always observed, which reduces the efficiency of the entire local self-government system. Adopted acts and the ones in force sometimes look, in many respects, broken and situational and do not always agree with each other. It should be noted that today a set of laws and regulations of local self-government is called a system with a certain degree of conditionality, as there are problems in ensuring its integrity and completeness.

A significant number of administrative-territorial units, presence therein of significant historical, economic, environmental, geographical and demographic 
features, ethnic and cultural traditions (recognized even at the constitutional level) objectively determine specifics of the structural organization of local self-government in these units, lead in each case to quite significant originality in terms of building a system and content of laws and regulations of local self-government. At the same time, they should not be detached from the general consistency existing in such area. Therefore, it is necessary to generalize the empirical experience of legal regulation of types and forms of laws and regulations of local self-government accumulated in recent years, the very mechanism of municipal law-making. In the context of reformation of the domestic local self-government system, change of its structure, expansion of the forms of public participation in the exercise of public power, serious work is needed to create a regulatory framework for the law-making process at the municipal level.

Improvement of the legal regulation of the system of regulations of local selfgoverning authorities and officials in Ukraine has several vectors. First of all, the constitutional reform in terms of decentralization should be completed. It should be noted that the Law "On Amendments to the Constitution of Ukraine (on the Decentralization of Power)" previously approved by the Verkhovna Rada of Ukraine on 31 August 2015 not only provides for the optimization of system-structural organization of local self-government, but also introduces in Art. 144 a general term for all laws adopted by local self-governments - "acts of local self-government" and states that they are "binding in the relevant territory" [93]. Such structure is seen as more successful compared to the current version of Part 1 of Art. 144 of the Constitution of Ukraine, which declares that "local self-governing authorities within statutory powers make decisions binding in the relevant territory" [94]. Since a decision in the context of Art. 144 of the current Basic Law is an authoritative act of will, not a specific name of regulations. Instead, the term "acts of local selfgovernment" more successfully emphasizes the subject under consideration, so its use is recommended in both law-making and law enforcement practice, as well as in legal science.

Also, the current Law of Ukraine "On Local Self-Government in Ukraine" should be correspondingly amended and supplemented [95]. In particular, name of Article 59 
of this Law should be changed from "Acts of Local Self-Governing Authorities and Officials" to "Acts of Local Self-Government", and its content should include the division of such acts into regulatory and individual, as well as characteristics of each of them by the subjects of local self-government with the indication of their names and legal force. At the same time, tendencies and contradictions, which have appeared in the law enforcement practice, and the need in the unification of the conceptual and categorical framework should be considered.

Besides, given the exceptional importance of statutes, it is advisable to make them mandatory for adoption by all territorial communities [96]. Despite the fact that the right to adopt a statute in the Law "On Local Self-Governments in Ukraine" is formulated as a possibility, its adoption is dictated by the urgent need to obtain an independent legal status by the relevant territorial community. This will lead to the transformation of simple population into a real territorial community as a comprehensive socio-territorial community with a collective interest, self-awareness and mentality. Thus, Art. 19 of this Law should be amended and provide for such mandatory rule. At the same time, given the supremacy of a statute of the territorial community in the hierarchy of regulations of local self-government, it is advisable to provide for its adoption only at a local referendum.

It is also necessary to complete the consideration and adoption of the Law of Ukraine "On Laws and Regulations" adopted by the Parliament in the first reading back in May 2011 [97]. This Law, if adopted, will regulate public relations related to the development, adoption, entry into force, state registration and record of laws and regulations, determine the system, types, hierarchy of laws and regulations and establish uniform requirements to the rule-making techniques for all subjects of rulemaking. According to this bill, territorial communities and local self-governing authorities are referred to the subjects of rule-making (Art. 3), and decisions of local referendums, local councils and their executive bodies, orders of village, settlement, city mayors, heads of city district, district, regional councils - to bylaws (Part 3 of Art. 6). Besides, it contains a number of important provisions on the hierarchy and legal force of regulations, including the ones adopted by the subjects of local self- 
SCIENTIFIC APPROACHES IN JURISPRUDENCE

government. In particular, according to Art. 7 of this bill, regulatory decisions of local referendums are adopted on the basis and in pursuance of the Constitution and laws of Ukraine, international treaties of Ukraine, decrees of the President of Ukraine, resolutions of the Verkhovna Rada of Ukraine, resolutions of the Cabinet of Ministers of Ukraine and have a higher legal force than laws and regulations of local councils, their executive bodies, village, settlement, city mayor or head of the city district, district, regional council. Instead, regulatory decisions of local councils are adopted on the basis and in pursuance of the Constitution and laws of Ukraine, international treaties of Ukraine, decrees of the President of Ukraine, resolutions of the Verkhovna Rada of Ukraine, resolutions of the Cabinet of Ministers of Ukraine and have a higher legal force than acts of their executive bodies or, respectively, orders of a village, settlement, city mayor or head of the city district, district, regional council.

The Laws "On Laws and Regulations" and "On Local Self-Government in Ukraine" should establish an exhaustive list of subjects of rule-making. Such list should include territorial communities, local councils and their executive bodies, as well as senior officials of territorial communities. Elders and bodies of the selforganization of population, given the specifics of their municipal legal status, cannot be recognized subjects of rule-making.

Also, local self-governing authorities need to develop Recommendations on the Issues of Organization of the General Legal and Rule-Making Work, which are completely absent today [98]. In the vast majority of local self-governing authorities, these issues are not comprehensively formalized or resolved. They are only partially reflected in the regulations on local councils and their executive committees. It is seen that the relevant document should not be a recommendation, but a framework. It is advisable that the relevant local councils adopt not Recommendations, but Regulations on legal acts of local self-government.

Diversification of the names of regulations of various local self-governing authorities and officials is a necessary measure and should facilitate their systematization, simplify the search for necessary acts, avoid confusion with the same names of acts in the process of law enforcement. 
Insufficient definition of the provisions of the current Law of Ukraine "On Local Self-Government in Ukraine" regulating types and forms of laws and regulations of local self-government, absence in this Law of the interrelation of forms and types of acts has caused the same shortcomings in the legal regulation of laws and regulations at the municipal level. As a result, regulation of the forms of laws and regulations of local self-government in the Law "On Local Self-Government" by linking the forms of such acts to the subjects of their adoption turned out to be too complicated and confusing. Therefore, it is considered expedient in the legal regulation of forms of laws and regulations of local self-government to take as a basis their types (regulatory and individual) and to unify forms of acts of separate types (for example, regulations of local councils are adopted in the form of decisions, and individual ones - in the form of resolutions).

It is also necessary to resolve the issue of the official publication of regulations of local self-governing authorities and officials as required by Art. 59 of the current Law of Ukraine "On Local Self-Government". First of all, we are talking about the establishment of official printed publications at all levels of local self-government, including at the level of communities. Since, according to Art. 15 of the Law of Ukraine “On Access to Public Information”, information administrators, including local selfgovernments are obliged to publish their laws and regulations and draft decisions to be discussed, as well as information on the regulatory and legal bases of their activities. Draft laws and regulations, decisions of local self-governing authorities developed by the relevant administrators must be published no later than 20 business days before the date of their consideration. Today, the process of creation and operation of such official printed publications of local self-governing authorities is complicated mainly by the lack of local budget funds, so the solution to this issue lies largely in the formation of capable territorial communities and allocation to local councils of the relevant budget transfers.

In territorial communities with a population up to 500 people, it is hardly advisable to create own printed publications. Therefore, it is expedient to publish regulations of authorities and officials of such small territorial communities (at least 
until their voluntary association into capable territorial communities) in joint official publications for authorities and officials of neighboring territorial communities.

At the same time, possibilities of the official publication of regulations of local self-government through the Internet should be expanded. As we know, formation of systems for the creation and development of websites of public authorities is associated with Decree of the President of Ukraine No. 683/2002 dd. 1 August 2002 "On Additional Measures to Ensure Openness in the Activities of Public Authorities" [99], which was expected to provide for the "obligation of public and local self-governing authorities to maintain web-pages and promptly (no later than five business days) post thereon official information on the activities of the relevant authorities, performance of programs, plans, current or repealed laws and regulations, forms and samples of documents, archival and other information, as well as timely posting on such webpages of draft acts and regulations". Unfortunately, since the adoption of the abovementioned Decree of the President of Ukraine, it has not been possible to fully ensure the presence of basic local self-governing authorities in cyberspace.

It should be noted that the Law of Ukraine "On the Basic Principles of the Information Society Development in Ukraine for 2007-2015" recognized acceleration of the development and implementation of the latest competitive information and communication technologies (ICT) in the activities of public and local self-governing authorities as one of the main strategic goals of the development of information society in Ukraine [100]. However, as the Cabinet of Ministers acknowledged, "the economic crisis has led to a decrease in funding for the National Informatization Program, which has reduced the impact of the Program on informatization processes in the country and increased decentralization of approaches to information society development by the relevant government agencies", as a result of which "local self-governing authorities in comparison with central executive bodies have a much lower level of information technology support of administrative and management processes, as well as development of information technology infrastructure and state information systems" [101]. Naturally, under these conditions, websites of local self-governing authorities have not become a common phenomenon, especially at the level of settlements and 
villages. Accordingly, mostly regional and district councils, as well as city councils and their executive bodies in large cities can afford publication of regulations on their websites.

According to Art. 9 of the Law of Ukraine "On the National Informatization Program", tasks of the National Informatization Program for the next three years and scopes of their budget funding for the next year are annually formulated by the Cabinet of Ministers of Ukraine and approved by the Verkhovna Rada of Ukraine [102]. Therefore, the task of the National Informatization Program for the next three years should provide for the completion of informatization of all local self-governing authorities and creation of full-text bases of regulations of local self-government at all levels of the administrative-territorial structure.

At the same time, it is necessary to implement recommendations on the prospects for the development of websites of local self-governing authorities: 1) to develop a standard list of information to be posted on the official websites of local self-governing authorities and to approve such list by a regulation of the authority of the central level; 2) to oblige the introduction of a single orderly structure for posting information on various official Internet representations of local self-governing authorities; 3) to develop and promote provision of administrative services for visitors to municipal websites as elements of e-government (registration, payment of utilities, taxes, fines, etc.); 4) to organize domain names of official websites of local self-governing authorities; 5) to introduce a standard search engine on all websites; 6) to introduce elements of interactivity on the websites of local self-governing authorities (possibility to send a letter to the authority from the website and receive an answer, hold Internet conferences, online forums) [103].

Finally, it is necessary to create at the regional level Registers of laws of local self-government for their further inclusion into the Unified Register of Regulations in Ukraine. The relevant standards are stipulated by the draft Law of Ukraine "On Laws and Regulations". In particular, Art. 49 of the mentioned bill provides for the state registration of bylaws adopted by local referendums, local councils and their executive bodies with the main territorial departments of justice. Creation of such registers will 
serve as a significant guarantee of ensuring the principles of the rule of law and legality in the implementation of rule-making activities at the municipal level, simplify the search for necessary documents by interested parties, strengthen public control over such acts.

Currently, the Ministry of Justice of Ukraine receives a significant number of complaints about issue by local self-governing authorities of laws and regulations that do not comply with the legislation in force. However, the main territorial departments of justice do not perform state registration of laws and regulations of local selfgoverning authorities and do not have leverages to repeal such acts. Therefore, in order to regulate the issue of state registration of laws and regulations of regional, district, Kyiv and Sevastopol city councils, village, settlement, city, city district councils, the Ministry of Justice prepared a draft Law of Ukraine "On Amendments to the Law of Ukraine "On Local Self-Government in Ukraine" [104].

Finally, it is necessary to emphasize the need for the formation of a municipal law-making policy as one of the forms of implementation of the municipal legal policy. It should be a scientifically sound, consistent activities of local self-governing authorities and officials aimed at better organization of the law-making process and be based on the principles of legality, transparency and scientificity. Municipal rulemaking policy should be aimed at improving the process of municipal law-making, so that rule-making activities of local self-governing authorities and officials are well thought out, clearly organized, consistent with the law-making policy of the state and aimed at the resolution of problems of territorial communities. The question of its effectiveness will depend on all these characteristics. 


\section{SECTION 8. INFORMATION TECHNOLOGY AND LAW}

\subsection{Current issues of information security of the state: the Ukrainian measurement}

The introduction of new information and communication technologies is the basis of socio-economic and scientific and technological progress - the informatization of society [105]. Instead, as noted by a well-known expert in the field of information wars G. Pocheptsov, information civilization, which came to humanity, changes not only the status of information, i.e. the role of its positive effects, but also dramatically expands the negative possibilities. We have before us a powerful tool for which there are no limits. Information wars of varying intensity have become a clear sign of our days [106]. Interest in this topic is particularly acute given the great potential of information networks to influence the basic institutions of the state and society, in particular, information security $[107,108]$.

Given the position expressed in the dissertation research M. Kubyavka, we can reasonably conclude that at the present stage the importance of indirect (soft) methods of influencing the course of political and economic processes in the states is rapidly growing. The leading place among the so-called soft methods of influence is, of course, occupied by the tools of non-forceful (informational) influence. And this is the main trend in society - the transition from, mainly, physical methods of hostilities (destruction or coercion), to, mainly, non-violent change in people's attitudes to the enemy - from hatred to acceptance. A similar trend is observed around the world, and $95 \%$ of all subversive efforts against another state are occupied by information warfare [109].

Thus, information relations go beyond purely informational and become a factor in special hostile operations and information wars. As noted by Yu. Turchenko, political and legal regulation of information relations in Ukraine is in the process of formation, respectively, the legal vacuum affects the process of reforming the military sphere... That is why the problems of regulating the information sphere, 
creating appropriate conditions for advanced development of domestic information production. The leading tool for the realization of national interests in the field of sociopolitical relations, as an information sphere, should be law [110].

As noted by prof. V. Bogdanovich, the most powerful influence on ensuring the military security of Ukraine is information; a significant part of external information threats is in fact a kind of military threat, and these threats are one of the most dangerous for the military security of the state [111].

Levchenko $\mathrm{O}$ the classification of the information weapon on means of conducting information struggle is offered. The author concludes that information weapons pose a special danger to information resources, computer systems and networks of public administration, financial and banking institutions, military and weapons management systems, as well as to the psyche, consciousness and subconscious of the population and personnel of the armed forces. In terms of their effectiveness and consequences, information weapons are equated to weapons of mass destruction [112].

At the same time G. Pocheptsov warns that the following seven purposes can take place on which information influences can be directed in the same way. These goals are: the army and its population, the army and the foreign population, between the various components within the army, guerrillas and the population, the army and the allied army, the country and the allied country, the country and neutral countries. The set of tasks to be solved in a military conflict has already been tested in a number of military situations. Thus, the legitimation of such use becomes an essential task for working with public opinion in the event of the use of force in a conflict. The process of legitimization can be divided into two components: it is the heroization of one's side and the demonization of the enemy's side. Heroization is facilitated by the short duration of hostilities, the absence of wounded and killed, because the archetype of the hero involves just such behavior. The demonization of the enemy side is expressed, first of all, in the negativization of its leader (he can immediately become both a drug addict and a madman) and its armed forces. In the latter case, a proven option of 
influence since the First World War is the demonstration of atrocities against civilians [106].

Information space, in principle, allows the existence of any type of information, which realizes its differences from the space of the physical plane. Only the processing of this information by a person is dangerous in its consequences. And not on physical consequences in the sense of the termination of functioning of an organism, and on the entered new norms of the allowed behavior. Information weapons do not destroy the information space, but rely on it. The information weapon forms the information space for itself, because in essence the information weapon is a means of intensive introduction of certain segments of the new information space [106].

Therefore, the possession of effective information weapons and means of protection against it in modern conditions is one of the priority areas of national security in the information sphere [112].

It should be noted that in most studies, including Russian-language [113] and Ukrainian-language [109], the effectiveness of information (psychological) operations (PsO) is considered by example, mainly outside Ukraine and Russia. Thus, it is noted that the first mass operation, called psychological, was carried out by the US Armed Forces in support of UN troops in the Korean War (1950-1953). In 1951, the Department of Psychological Operations was established in the Ministry of the Army. was reformed into the Office of Special Methods of War. At the same time, the training of special personnel began. PsOs were widely used in Panama and the Persian Gulf, where US experts conducted information operations against Saddam Hussein's regime to protect the Kurdish population and Shiite Muslims from Baghdad's policies. Largescale PsOs were also carried out under Operation Sea Angel and Support for Democracy (Haiti, 1991, 1994), Revival of Hope and Common Shield (Somalia, 19921995), and Joint Efforts. (Bosnia, 1996). Virtually all peacekeeping companies in which the United States participates are accompanied by psychological operations. It is noted that if in the First World War one journalist accounted for 20,000 servicemen, then during the operation in Bosnia - for 500 servicemen [109]. 
At the same time, Ukraine has its own «sad experience» of information attacks on itself. As noted by Yu. Gorban', in the information war against Ukraine, the Russian Federation uses almost the entire arsenal of influence on people's consciousness [114]. In particular, observers note that, for example, all 23 years of Ukraine's independence, anti-Ukrainian propaganda was conducted on Crimean television ${ }^{1}$. G. Pocheptsov emphasizes that before the events of 2013-2014, $60 \%$ of the adult population of Ukraine received socio-political information through television. At the same time, $54.5 \%$ of the population preferred information and analytical programs on Russian television [106].

Russian journalist A. Babchenko writes ${ }^{2}$ : «Putin's propaganda took all the disgust out of the people, turned the worst into good, allowed murder, xenophobia, obscurantism, persecution, harassment, hatred, aggression, racial intolerance... - and it turned out to be incredibly effective... I'm sure - no "Krymnash" ${ }^{3}$ would be possible without all these series about cops, investigators, murders, kidnappings, brigades, killers, corpses, "investigation" "against" maniacs, rape of children, dismembered human bodies in three-liter jars and chernukha, chernukha, chernukha ${ }^{4} \gg$. Apparently, it is not accidental that in 2004 the President of the Russian Federation V. Putin spoke

\footnotetext{
${ }^{1} \mathrm{http} / / /$ obozrevatel.com/blogs/87465-novosti-kryimnasha--bal-satanyi.htm

${ }^{2} \mathrm{https}$ //rusmonitor.com/arkadijj-babchenko-putinskaya-propaganda-dostala-iz-lyudejj-vsyumraz.html

${ }^{3}$ a Russian-language neologism, Internet meme, ideological cliché, and the hashtag \#KrymNash, which originated and gained popularity and support in Russia against the background of the preparation and implementation of Russian armed aggression against Ukraine and during the annexation Crimea (Russian: «Крымнаш»; Ukrainian: «Кримнаш»)

Source:

https://uk.wikipedia.org/wiki/\%D0\%9A\%D1\%80\%D1\%8B\%D0\%BC\%D0\%BD\%D0\%B0\%D1\%8 8

${ }^{4}$ 1) the dark sides of life, everyday life, imbued with doom and hopelessness, accompanied by scenes of cruelty and violence, as well as the display of such gloomy, unsightly aspects of life. Distributed primarily in the cinema and literature (Russian: «чернуха»; Ukrainian: «чорнуза»; French: noir) Source: https://ru.wikipedia.org/wiki/\%D0\%A7\%D0\%B5\%D1\%80\%D0\%BD\%D1\%83\%D1\%85\%D0\%B0 ( $\%$ D0\%BA\%D0\%BB\%D0\%B8\%D1\%88\%D0\%B5)

2). a gloomy genre of Russian horror - everything negative in everyday life (e.g. cruelty, poverty, violence, etc.)

Source:

https://ru.glosbe.com/ru/en/\%D1\%87\%D0\%B5\%D1\%80\%D0\%BD\%D1\%83\%D1\%85\%D0\%B
} 
out against restrictions on the broadcasting of scenes of violence on Russian television, noting, in particular, that such a ban «would affect the patriotic upbringing of minors, largely due to the demonstration of films about the exploits and courage of our compatriots $»^{5}$.

The opinion expressed by A. Babchenko corresponds to the position of the harmfulness of propaganda of violence and cruelty - and not only for public morality as such. This propaganda, which was mainly introduced to Ukrainian television by Russian TV and video products, was not timely assessed by the Ukrainian authorities as threatening, not only in terms of a threat to public morality, but also in terms of a threat to national security.

A resident of Donetsk: «I remember this "referendum"6. A few days earlier, on one of the Russian TV channels, the news anchor said that in Donetsk, signs were put on the homes of Russian-speaking citizens. My wife and I giggled then. What nonsense! .. Then this nonsense was seriously retold to each other by people in the referendum... And we suddenly realized that the people began to go crazy en masse» ${ }^{7}$.

Thus, Russian propaganda has caused and continues to cause enormous damage to Ukraine's national security, actually leading to the death of people, so restricting such propaganda corresponds to a legitimate goal - to ensure national security - and is necessary in a democratic society.

For a long time during the war in Donbas, Russian news agencies and the media massively published and continue to publish false and propaganda «news» of anti-

\footnotetext{
${ }^{5} \mathrm{http}: / /$ moral.ru/news/04_1222_Putin_smi.htm

${ }^{6}$ Illegal referendum on 11.05 .2014 on the «state independence» of Donetsk region, which was initiated by pro-Russian separatists and held in violation of the Constitution of Ukraine, and its results were not recognized by the Ukrainian authorities and were not recognized by the European Union and the United States. Simultaneously with the referendum in Donetsk region, a similar referendum was held in Luhansk region on the status of the so-called «Luhansk People's Republic».

Source:

https://uk.wikipedia.org/wiki/\%D0\%A0\%D0\%B5\%D1\%84\%D0\%B5\%D1\%80\%D0\%B5\%D0\%B D\%D0\%B4\%D1\%83\%D0\%BC\%D0\%B8_\%D0\%BD\%D0\%B0_\%D0\%94\%D0\%BE\%D0\%BD\% D0\%B5\%D1\%87\%D1\%87\%D0\%B8\%D0\%BD\%D1\%96\%D1\%82\%D0\%B0 \%D0\%9B\%D1\%83 $\% \mathrm{D} 0 \% \mathrm{~B} 3 \% \mathrm{D} 0 \% \mathrm{~B} 0 \% \mathrm{D} 0 \% \mathrm{BD} \% \mathrm{D} 1 \% 89 \% \mathrm{D} 0 \% \mathrm{~B} 8 \% \mathrm{D} 0 \% \mathrm{BD} \% \mathrm{D} 1 \% 962014$

${ }^{7} \mathrm{http} / /$ hronika.info/obwestvo/141857-kak-zhivetsya-v-donecke-posle-dvuh-let-v-dnr.html
} 
Ukrainian orientation ${ }^{8}$ : «crucified boy ${ }^{9}$, «mother of the crucified boy tied to a tank and dragged across the square», «two slaves» ${ }^{10}$, «devoured bullfinches, in contrast to the tits of patriotic color» ${ }^{11}$, «drunken negroes dance on Ukrainian tanks», "Yatsenyuk ${ }^{12}$ fought in Chechnya and participated in the torture and execution of Russian prisoners of war»; «Avdeevka is shelled by the Ukrainian army» ${ }^{13}$, etc. There is no reason to allow these agencies and the media to legitimately disseminate this information in Ukraine. Thus, the Representative of Ukraine to the UN, Ambassador V. Yelchenko in a speech to the UN on $11.05 .2016^{14}$ pointed out that «cruel and vicious propaganda disseminated by the state media in Russia is one of the main elements of the hybrid aggression of the Russian Federation. There is a need to combat such phenomena as state propaganda of intolerance and hatred».

It is interesting to note that back in 1953 in the science fiction novel-anti-utopia «451 degrees Fahrenheit» (English: «Fahrenheit 451») Ray Bradbury showed the dangers of a society where reality is formed and controlled by television (in a broad

\footnotetext{
${ }^{8} \mathrm{https}$ ://www.06277.com.ua/news/801960/polnoe-sobranie-lzi-rossijskih-smi-vypusk-1

${ }^{9}$ The television story about the «crucified boy» - the unofficial title of the television news story «A refugee from Slavyansk recalls how with her the young son and the wife of the militiaman» were executed under her, shown on July 12 and 13, 2014 on the Russian Channel One. The report contained «evidence», which was not subsequently confirmed, about the alleged bullying of Ukrainian security officials against residents of the city of Slavyansk, who supported the DPR, including the crucifixion of a three-year boy in front of his mother.

The scandalous story received a significant public outcry: it confirmed the evidence of extreme lack of professionalism and the use of Russian state-owned media in the information war to incite hatred and enmity, as well as evidence that «misinformation» and «falsehood» «became the norm» for Russian state-owned media

Source:

https://ru.wikipedia.org/wiki/\%D0\%A2\%D0\%B5\%D0\%BB\%D0\%B5\%D1\%81\%D1\%8E\%D0\%B6 $\% \mathrm{D} 0 \% \mathrm{~B} 5 \% \mathrm{D} 1 \% 82 \_\% \mathrm{D} 0 \% \mathrm{BE} \_$DD1\%80\%D0\%B0\%D1\%81\%D0\%BF\%D1\%8F\%D1\%82\%D0\% BE\%D0\%BC_\%D0\%BC\%D0\%B0\%D0\%BB\%D1\%8C\%D1\%87\%D0\%B8\%D0\%BA\%D0\%B5

${ }^{10}$ The fake story of the Russian First Channel about the Ukrainian military, who was allegedly promised «a piece of land and two slaves for the executions of civilians in the Donbass»

Source:

https:/gordonua.com/news/war/klochok-zemli-i-dva-raba-reakciya-socsetey-na-feyk-ot-sozdateleyraspyatogo-malchika-49620.html

${ }^{11}$ Fake information of the Russian media that Ukrainians eat bullfinches, because they are red in color, and protect the yellow-blue titmouse

12 Prime Minister of Ukraine (2014-2016)

${ }^{13}$ which itself at this time controls the city and provides life there $14 \mathrm{http}: / /$ hvylya.net/news/digest/ukraina-v-oon-ofitsialno-obvinila-rossiyu-v-podderzhketerrorizma.html
} 
sense - the media). According to Abdol Hossein Joodaki, in «Fahrenheit 451», Ray Bradbury creates a dark futuristic world that does not want a well-educated, wellinformed population capable of critical thinking. For the system, a good citizen is one who does not dare to form his own opinion. Literate citizens are willing to serve the system, allowing the government to make all decisions for them. The system suffers from mass unification and homogenization. Books are banned, and a mindless society is immersed in various kinds of distractions, such as television, radio, loud music, drug addiction, drugs and fast cars as ways to be happy and escape from the responsibilities and realities of life. The media are used as a powerful tool for social control and the elimination of differences and originals [115].

At the same time, the Internet creates incomparably greater opportunities for the distribution of unwanted content than television and radio. O. Vergolyas points out that the on-line social network, in terms of information and communication technologies, creates conditions for the use of much more tools of information and psychological influence than off-line due to technological capabilities for placement and delivery of audio and video information to the recipient. On-line networks have a much wider range of options for placing and delivering information to the recipient of various kinds (video, pictures, photos, text, audio). The speed of information dissemination in the online network is much higher than in the off-line network due to the simplicity of transmission and broadcasting. In addition, it is worth noting that the production, distribution and delivery to the recipient of information products (content) for distribution in the on-line network requires much less human and material resources than in the on-line network, especially for due to the speed of distribution and extremely low cost of animation of information materials [116].

Thus, information networks create all opportunities for the delivery of hostile cultural and/or informational content. For example, according to American experts, up to $75 \%$ of the so-called «life stories» and «references to sources» given in comments on social networks during the intensification of anti-Ukrainian aggression were almost entirely fictional [117]. In particular, G. Pocheptsov [106] reports that Gleb Pavlovsky, presented by «Komsomolskaya Pravda» (26.02.1999) as a «veteran of information 
wars», pays special attention to various Internet projects, considering them as an ideal tool for launching the necessary stories into the mass consciousness. He says: «Traditional media are responsible for the information they disseminate. Rumors transmitted via the Internet are anonymous. But then newspapers and television get the opportunity to link to the Internet. That is, there is a real laundering of so-called "black" information. Previously, this "black" information could only be made "gray" - to distribute it on the sidelines, no more. Now it is possible to launder any "misinformation" completely».

O. Mitenko also emphasizes that the lack of mechanisms of state control over the dissemination of information through Internet sites causes a rapid increase in the volume of socio-political content (anonymous, the authenticity of which is questionable, provocative and openly illegal), which are duplicated by traditional domestic media with a link to the Internet [118].

O. Golub reports that many experts emphasize the danger of using social networks as a source of information, because the so-called new media is one of the most common ways of spreading false information and fakes. It is noted that in recent years, more and more classic media use social networks as primary sources. Then this unverified information gets on television and spreads to a mass audience. There is no doubt about the danger of spreading false information in the context of the information war, which is part of the hybrid war that Russia is waging against Ukraine. This affects not only the civilian population of Ukraine, but also demobilizes the military defending their country. All these technologies have long been tested. Research shows that people consider the most important topics and issues that are actively covered and discussed in the media. In this way, it is possible to purposefully adjust the perception of society - in fact, to form a new reality.

According to the StopFake website, false news is spread primarily by the Russian media. That's why journalists should be especially careful to check information from social networks, so as not to become carriers of fakes. It is the journalist's responsibility to verify and process the information received. In fact, this is how traditional media 
should differ from social networks and aggregator sites [119].

The article [120] emphasizes that the events in the Autonomous Republic of Crimea had a clearly defined virtual information component. If we call it propaganda, it would reduce the treacherous and poisonous nature of this information war. The principles of the electronic cyberattack were transformed into an uncontrolled unimpeded flow of Russian-language disinformation announcing a new war with the «fascists». A version of the reality of oppression, persecution and intimidation of the Russian-speaking population of Ukraine was created, which was spread to destabilize the situation in the country. Foreign news agencies covered the fake news as if they really had reason to discuss. As a result, the falsifications, confusion and fear they cause, prevented a quick response to the actions of the Russian Federation and weakened the determination of those who were to do so [120].

Conclusions. In the modern world, freedom of speech, which is considered the highest value of a democratic society, through the efforts of architects of information wars becomes a formidable weapon of hostile influences - information weapons. This was fully manifested during the hybrid aggression of the Russian Federation against Ukraine: a large population, historically or due to the weakness of Ukraine's propaganda structures, was under the influence of the Russian media, succumbed to anti-Ukrainian sentiment and sided with the aggressor. Therefore, the possession of effective information weapons and means of protection against it in modern conditions is one of the priority areas of national security in the information sphere. Compliance with such requirements will sooner or later require states to make legal decisions to restrict hostile content in the interests of their own security, taking into account the convention obligations of a democracy.

Висновки. У сучасному світі свобода слова, яка вважається вищою цінністю демократичного суспільства, стараннями архітекторів інформаційних воєн перетворюється на грізну зброю ворожих впливів - інформаційну зброю. Зазначене у повній мірі проявилося у період гібридної агресії РФ проти України: велика кількість населення, що історично або внаслідок слабкості 
пропагандистських структур України, знаходилося під впливом російських засобів масової інформації, піддалася антиукраїнським настроям і стала на бік агресора. Тому володіння в сучасних умовах ефективною інформаційною зброєю i засобами захисту від неї є одним із пріоритетних напрямів забезпечення національної безпеки в інформаційній сфері. Відповідність таким вимогам рано чи пізно потребуватиме від держав правових рішень щодо обмеження ворожого контенту в інтересах власної безпеки, з урахуванням конвенційних зобов'язань демократичної держави. 


\section{SECTION 9. INTERNATIONAL ECONOMIC LAW}

\section{1 Доктринальні підходи щодо сутностей та особливостей міжнародного економічного права}

Рівень цивілізованості держави передусім визначається іï економічним статусом. Країна з високим економічним статусом має змогу не лише забезпечувати добробут своїм громадянам, але й займати домінантне становище на міжнародній арені, мати авторитет у міжнародному співтоваристві. Водночас перед країнами у XXI ст. світова економіка ставить нові завдання. Сильні гравці за умови акумуляції зусиль дедалі більше нарощуватимуть капітал, прогнозується тенденція до зміцнення позиції світових економічних центрів. Слабкі ж держави мають дедалі менше можливостей для зростання.

Міжнародному економічному праву (МЕП) у цьому процесі належить особлива роль. По-перше, воно є основним важелем забезпечення порядку в міжнародних економічних відносинах. По-друге, МЕП є засобом встановлення еталона окремих суспільних відносин в конкретній державі шляхом визначення умов вступу до міжнародних економічних організацій. Окрім того, норми міжнародного економічного права є юридичним пропуском органів державної влади і державних суб’єктів господарювання на міжнародну арену.

Міжнародне економічне право $є$ галуззю міжнародного права, яка з'явилася у XX ст. Першим і основоположним чинником його появи був поступальний розвиток зовнішньоторговельних відносин держав між собою. Відбувалося взаємопроникнення міжнародних економічних зв’язків та наростання економічної взаємозалежності держав, міждержавна взаємодія в економічній сфері стала необхідністю. Умовами, у яких формувалися міжнародні економічні відносини (MEB) у їх сучасному вигляді, були: поділ праці, спеціалізація держав у виробництві одних товарів та необхідність імпорту інших; глобалізація низки міжнародних процесів: одні держави зазнавали впливу економічних криз, які відбувалися в інших; значні прірви в економічних статусах 
SCIENTIFIC APPROACHES IN JURISPRUDENCE

різних країн, що унеможливлювало справедливу конкуренцію, вело до перебільшеного авторитету одних держав перед іншими.

На сьогодні процес формування міжнародного економічного права триває, адже економічні умови, у яких функціонують держави, постійно змінюються. Незаперечною історичною та сучасною реальністю економічних інтересів держав є змагальність. Сьогодні, як і колись, має місце змагання національних економічних інтересів держав: у відношенні природних ресурсів, економічної інфраструктури, інформаційних полів, інтелектів, тобто всього, що дозволяє державам розвивати свої національні економіки. Шляхи і форми вирішення таких конфліктів, звичайно, з плином часу змінилися. У сучасних умовах різко зросло значення міжнародно-правових механізмів у світовій політиці. Спільний інтерес держав полягає в тому, щоб створити максимально вигідні для себе стабільні юридичні правила гри у світовій економіці, які заразом були б взаємоприйнятні для всіх [121].

Отже, поява міжнародного економічного права - це встановлення загальновизнаного і загальнообов’язкового регулятора світових суспільних відносин в економічній сфері.

МЕП забезпечує виконання таких функцій: нормативна фіксація умов міжнародної економічної співпраці, прав та обов’язків іiі суб'єктів; чітка регламентація порядку врегулювання міжнародних економічних спорів; можливість створення міжнародних органів для підвищення якості співпраці; створення та порядок вирішення справ міжнародними судовими органами; легалізація міжнародно-правових звичаїв, принципів і санкцій.

Завдяки означеним функціям МЕП є інструментом досягнення таких цілей: забезпечення економічної безпеки держав; контроль за виконанням домовленостей; досягнення балансу і координації протилежних економічних інтересів; можливість економічного росту для країн, що розвиваються [122, 123 , $124]$.

Серед ознак міжнародного економічного права можна виділити такі: 
SCIENTIFIC APPROACHES IN JURISPRUDENCE

- міжнародне економічне право регулює специфічну сферу суспільних відносин між країнами - відносини, які пов’язані з економічною діяльністю держав на міжнародному рівні;

- міжнародне економічне право $є$ інструментом регулювання вказаної сфери відносин, метою якого є їх впорядкування і гармонізація, забезпечення їх надійності і стабільності, а також економічної безпеки держав;

- принципи i норми міжнародного економічного права мають універсальний характер. Ще автор першого на теренах СРСР підручника 3 міжнародного економічного права М.Богуславський писав, що тенденцією міжнародного права є його цілісність і загальність, а його принципи і норми поширюються на нові сфери міжнародних відносин, у чому й проявляється універсалізм [125];

- МЕП $є$ засобом вирішення глобальних світових проблем в економічній сфері (наприклад, зубожіння бідних держав і збагачення заможних, збереження окремою державою національного суверенітету над власними природними ресурсами, контроль над діяльністю транснаціональних корпорацій тощо);

- МЕП - лише один з регуляторів міжнародних економічних відносин. Разом із цією галуззю міжнародного права міжнародні економічні відносини регулюються нормами внутрішнього права, неправовими нормами тощо. Ці норми різняться за природою, але в ході регулювання міжнародної економічної діяльності вони взаємодіють між собою.

Становлення науки міжнародного економічного права (МЕП) пройшло непростий шлях i відбувалося в декілька етапів. Вперше концепцію «міжнародного господарського права» (МГП) сформулював В. Корецький в 1920-х роках. Тоді дисципліна МГП була міжгалузевою, мала комплексний характер, ïi одночасно утворювали норми міжнародного і цивільного права. У межах сформульованої концепції багато уваги В. Корецький приділяв принципам міжнародного публічного права. У 1946 р. І. Перетерський виділив «міжнародне публічне цивільне право». У 1967 р. Г. Тункін сформулював сферу відносин, яку йменували міжнародним економічним правом. Про необхідність 
SCIENTIFIC APPROACHES IN JURISPRUDENCE

нової галузі в міжнародному праві - міжнародного економічного права, зазначив Е. Усенко. У 1982 р. в підручнику з міжнародного права він помістив главу під назвою «Міжнародне економічне право», де давалося визначення МЕП i зазначалися його основні принципи. Одночасно теоретики міжнародного права Г. Вельямінов і В. Лісовський пропонували нову галузь міжнародного права назвати «міжнародним торговим правом». Взагалі питання, пов’язані з МЕП, довгий час були предметом наукових дискусій, результати яких Україна одержала в науковий спадок.

Існує плюралізм думок про МЕП як галузь міжнародного права, його предмет і систему. Відтак розроблено такі наукові теорії МЕП:

1. МЕП є галуззю міжнародного публічного права. Згідно з цією теорією, як галузь міжнародного публічного права МЕП охоплює: а) володіння i використання природних ресурсів; б) виробництво і розподіл товарів; в) невидимі міжнародні угоди фінансового та економічного характеру; г) фінанси і кредити; д) послуги і правовий статус суб’єктів, які їх надають. Відповідно, до предмета регулювання МЕП у цій концепції не входить внутрішнє регулювання.

Засновник: Г. Шварценбергер. Прибічники: П. Верлорен ван Темаат, П. Піконе.

2. МЕП поширюється, по-перше, на відносини між публічними особами, подруге, на усі види господарських відносин: і внутрішньодержавні, i міжнародні. Відповідно, для цієї теорії характерне поєднання публічного-правового i приватноправового механізму правового регулювання МЕП. Необхідність іiі розробки випливала з правової дійсності: а) правотворчої функції міжнародних організацій; в) провадження діяльності ТНК; б) реалій та необхідності правового регулювання міжнародних відносин нормами внутрішньодержавного права та приватноправовими нормами; г) органічної єдності міжнародного приватного права і міжнародного публічного права в силу спільних джерел, а також загрози переродження цивільно-правового конфлікту в міждержавний $і$ навпаки. Невдовзі, як наслідок, історично перша «публічно-правова» концепція МЕП 
SCIENTIFIC APPROACHES IN JURISPRUDENCE

втратила свою актуальність. Теорій, де основою є поєднання двох протилежних засобів правового регулювання, у міжнародному праві є досить багато.

Прибічники: В. Корецький, Г. Ерлер, В. Фікентштер, І. Шаповалов та ін.

Більшість теорій, розроблених у сучасний період, основані саме на теорії поєднання. Різняться вони лише незначними нюансами або більш вагомими уточненнями. Серед сучасних теорій назвемо:

- Введення до складу МЕП норм транснаціонального права (lex mercantoria) (Ф. Джессеп). Під транснаціональним правом розуміють сукупність правових норм наднаціонального характеру, яка діє при перетині особами і майном кордону, не пов'язана 3 внутрішнім правом держав i заснована на загальних принципах цивілізованих країн. Необхідність lex mercantoria обгрунтовують існуванням у добу Середньовіччя, у період феодальної роздробленості, єдиного для всіх купців купецького права, внаслідок чого купці уникали залежності від окремого для кожного міста права. У наш час МТП формулює на багатосторонній основі норми транснаціонального права: міжнародні правила 3 тлумачення торговельних термінів Інкотермс тощо;

- $\quad$ Поширення МЕП на відносини, які виникають через необхідність орієнтації на розвиток країн 3 низьким рівнем життя (доктрину пропонують науковці самих же країн з низьким рівнем життя). Низка держав, які у ХХ ст. стали незалежними і розпочали новий шлях економічного розвитку, зіткнулися з існуванням економічної системи в інтересах розвинених держав (наприклад, Бреттон-Вудської міжнародної економічної системи). Такий стан справ сприяв нарощенню капіталів імперіями й одночасному зубожінню бідних держав. Відповідно, з’явилася потреба встановити Новий міжнародний економічний порядок (НМЕП), у рамках якого ГА ООН прийняла Програму дій щодо встановлення нового міжнародного економічного порядку (1974) та Хартію економічних прав і обов'язків держав (1974). Для вступу третіх країн до МЕО почали застосовувати умови членства соціально-економічного характеру, багато 3 яких є юридичного характеру, зокрема, привести внутрішнє законодавство у відповідність до норм міжнародного права. Для багатьох країн, що 
розвиваються, поставлені вимоги є недосяжними. 3 іншого боку, як зазначають у спеціальній літературі, демократично-правова система європейського типу неможлива поза існуванням правових законів, які для своєї реалізації потребують правової держави 3 відповідним розподілом влади, дієвим конституційно-правовим контролем, іншими юридичними засобами забезпечення принципу законності [126]. Тому встановлення цензу доступу до міжнародних організацій передбачає й можливість національного прогресу для країн, що розвиваються, і не є однозначно негативним міжнародно-правовим явищем;

- Поширення норм МЕП, зокрема, на приватних підприємців, які здійснюють міжнародну економічну діяльність, а також на їх майно (аргументується безпосереднім чи опосередкованим поширенням МЕП на приватних суб'єктів міжнародних економічних відносин) (Д. Карро і П. Жуйара);

- Заміна «міжнародного економічного права» на «міжнародне комерційне право» (МКП), під яким розуміють систему правових норм, котрі $\epsilon$ засобом регулювання інтернаціональних господарських, комерційних зв’язків на міжнародному рівні шляхом ухвалення спільних оптимальних рішень з боку держав, міжнародних організацій, суб’єктів міжнародної комерційної діяльності (комерсантів) [127]. Ця теорія, як випливає з цитованого визначення, за своєю суттю відповідає концепції поєднання публічно-правового і приватноправового регулювання в МЕП, лише одержала іншу назву. Як зазначають у літературі, така інтерпретація $\epsilon$ помилковою тому, що міжнародне економічне право відокремлюється від інших галузей міжнародного права не поняттям комерції $\mathrm{i}$ прибутку, а більш широким й абстрактним поняттям економічної вигоди, матеріальної цінності [128].

Дослідники сходяться на тому, що міждержавні відносини є сферою міжнародного публічного права, а відносини між громадянами й організаціями різних держав входять до міжнародного приватного права. Основні дискусії тривають навколо міжнародного приватного права i місця його галузей та 
SCIENTIFIC APPROACHES IN JURISPRUDENCE

інститутів у МЕП, дискусійним на сьогодні $є$ питання про належність міжнародного приватного права до міжнародного чи внутрішнього права.

Отже, міжнародне економічне право з'явилося як регулятор зовнішньоторговельних міжнародних економічних зв'язків. Основними чинниками його появи були необхідність економічної інтеграції держав та поява міжнародних організацій. Ознаками цієї галузі права $є$ : регулювання відносин, які пов'язані з економічною діяльністю держав на міжнародному рівні, а також те, що МЕП $\epsilon$ інструментом регулювання вказаних відносин, засобом розв'язання глобальних світових проблем в економічній сфері та лише одним 3 регуляторів міжнародних економічних відносин.

Існує дві протилежні за змістом доктрини МЕП. Перша виходить 3 того, що МЕП є галуззю міжнародного публічного права, а друга - що в МЕП поєднано публічно-правовий і приватноправовий елементи. На основі другої доктрини утворилися такі сучасні концепції МЕП, кожна 3 яких має своїх прибічників: введення до складу МЕП норм транснаціонального права (lex mercantoria); поширення МЕП на відносини, які виникають через необхідність орієнтації на розвиток країн з низьким рівнем життя, поширення норм МЕП, зокрема, на приватних підприємців, заміна «міжнародного економічного права» на «міжнародне комерційне право». 


\section{SECTION 10. LABOR LAW, SOCIAL SECURITY LAW}

\section{1 Атестація науково-педагогічних працівників у закладі вищої освіти та ії правове регулювання}

Одним з традиційних способів оцінки персоналу в організаціях $є$ періодична атестація, що передбачає процедуру оцінювання відповідності діяльності конкретного працівника стандарту виконання роботи на даному підприємстві та на даній посаді. У період до незалежності України атестація була обов'язковим елементом роботи з кадрами, а потім настало певне затишшя у даному напрямку. Наразі атестація знову входить у систему роботи з персоналом на підприємствах незалежно від їх форми власності. Керівник оцінює своїх співробітників з метою підвищення ефективності їх роботи та визначення необхідності підвищення їх кваліфікації. Регулярне проведення атестації позитивно впливає на професійний розвиток і зростання працівників, їх мотивацію. У той же час результати атестації дуже важливі для керівника, оскільки дозволяють приймати обгрунтовані рішення щодо розвитку, просування, звільнення та преміювання персоналу.

У даному розділі ми проведемо стислий аналіз правового регулювання атестації науково-педагогічних працівників на державному рівні і на рівні навчальних закладів вищої освіти України.

Питанню проведення атестації працівників присвячено чимало досліджень, основна маса яких розглядає їх у технологічному чи психологічному аспектах, a не в правовому, що актуалізує дане дослідження. При написанні розділу авторами були використані матеріали, опубліковані в журналах «Довідник кадровика», «Управління персоналом» та ін. [129-132]. Джерелами для дослідження слугували такі нормативно-правові акти, як Кодекс законів про працю, Закони України «Про вищу освіту» та «Про наукову і науково-технічну діяльність», Положення про атестацію наукових працівників та ін. [133-136]. 
На даний час в Україні не існує єдиного загальнодержавного нормативноправового акта, що регулював би проведення атестації. Тому регламент проведення атестації визначається або в галузевому порядку, або самим керівництвом підприємства чи організації. Проте, за час систематичного проведення атестації працівників у радянський період накопичився достатній досвід, що дозволяє використовувати його сьогодні з деякою адаптацією до умов української ринкової економіки.

Поняття атестації науково-педагогічних працівників не визначено в нормативно-правовій літературі. Однак у Положенні про атестацію наукових працівників, затвердженому Постановою Кабінету Міністрів України, чітко позначається мета атестаційного процесу - встановлення відповідності кваліфікації наукового працівника займаній посаді [136].

Вимагає пояснення саме визначення «науковий працівник», оскільки поняття «науково-педагогічний працівник» у згаданому Положенні відсутня. Його дає Закон України «Про наукову і науково-технічну діяльність», який визначає науково-педагогічного працівника як вченого, який професійно займається за основним місцем роботи педагогічною і науковою або науковотехнічною діяльністю у вищих навчальних закладах та закладах післядипломної освіти III-IV рівнів акредитації (ст. 1) [135].

Той же Закон (ст. 6) зобов'язує науковця постійно підвищувати свою кваліфікацію і в установленому порядку проходити атестацію на відповідність займаній посаді [135]. Результати підвищення кваліфікації науковопедагогічного працівника повинні враховуватися під час його атестації (ст. 19), підсумки якої затверджує вчена рада навчального закладу (ст. 10) [135].

Згадане вище положення про атестацію наукових працівників конкретизує порядок проведення атестаційного процесу. Так, у п. 2 визначено ті параметри, відповідно до яких оцінюється той або інший науково-педагогічний працівник: рівень професійної підготовки; результативність його роботи; ефективність праці 3 урахуванням конкретних вимог до цієї категорії 
SCIENTIFIC APPROACHES IN JURISPRUDENCE

працівників; перспективи використання здібностей науково-педагогічного працівника; способи стимулювання підвищення його професійного рівня, потреби у підвищенні кваліфікації та професійної підготовки.

Таким чином, оцінюється три показники діяльності працівника: кваліфікація, ставлення до роботи і результативність роботи. Як бачимо, на перше місце ставиться комплексна оцінка працівника, однією зі складових якої $\epsilon$ його кваліфікація. У той же час, відповідно до Кодексу законів про працю України (п. 2 ст. 40), трудовий договір може бути розірваний 3 працівником у разі виявлення невідповідності займаній посаді або виконуваній роботі внаслідок недостатньої кваліфікації, що перешкоджає продовженню даної роботи [133]. Інші характеристики працівника, що оцінюються під час атестації, не беруться до уваги. Виходить деяка невідповідність між трудовим законодавством i методиками оцінювання, що застосовуються під час атестації. Усунути наявну невідповідність відносно нескладно, наприклад, шляхом уведення в Положення про атестацію як обов’язкову умову звільнення низький рівень кваліфікації працівника. Крім того, доцільно було б уточнити формулювання звільнення в Кодексі законів про працю України та викласти його як «виявлену невідповідність ... внаслідок недостатньої кваліфікації, підтвердженої результатами атестації ». Таке формулювання створює працівнику додаткові гарантії при розірванні трудового договору, коли він може бути звільнений не просто за рішенням власника, а тільки після колегіального рішення атестаційної комісії.

Відповідно до Положення, затвердженого Кабінетом Міністрів України, атестація науково-педагогічних працівників проводиться не рідше одного разу на п’ять років і не раніше, ніж через один рік перебування працівника на посаді [136]. Періодичність атестаційного процесу науково-педагогічних працівників затверджується наказом керівника вузу на початку календарного року (п. 5). До відома працівника терміни і графік проведення атестації доводяться не пізніше, ніж за один місяць. Атестація проводиться в індивідуальному порядку в одній або кількох комісіях, створених за наказом керівника навчального закладу, до 
складу якої залучаються висококваліфіковані науково-педагогічні працівники і представник профспілкового органу [136].

На науково-педагогічного працівника, який підлягає атестації, заздалегідь складається характеристика, підписана його безпосереднім керівником. Характеристики керівників структурних підрозділів підписуються ректором вузу (п. 11 Положення). Така характеристика повинна бути доведена до відома атестаційної комісії і працівника, який підлягає атестації (для ознайомлення) не пізніше, ніж за два тижні до иіï проведення.

Під час атестації науково-педагогічний працівник звітує перед комісією про свою роботу в присутності свого безпосереднього керівника (п. 13 Положення). Атестаційна комісія приймає своє рішення відкритим або закритим голосуванням без присутності працівника, який підлягає атестації. Це рішення вважається правомочним, якщо в його прийнятті бере участь не менше 2/3 складу атестаційної комісії і приймається простою більшістю голосів. Рішення щодо працівника комісія може прийняти і за його відсутності, якщо таке мало місце без поважних причин.

На підставі комплексу даних, таких, як характеристика і звіт працівника, інших поданих матеріалів, атестаційна комісія приймає рішення з одним 3 таких формулювань: «відповідає займаній посаді» і «не відповідає займаній посаді» [136]. У своєму рішенні комісія може дати рекомендації щодо заохочення науково-педагогічного працівника, зміну посади, розміру посадового окладу, необхідності призначення позачергової атестації. Усі зазначені рекомендації можуть бути розглянуті керівником вищого навчального закладу протягом одного року з дня проведення атестації (п. 17 Положення).

Рішення атестаційної комісії затверджується на Вченій раді навчального закладу вищої освіти протягом одного місяця з дня його надходження до ради.

Якщо атестаційна комісія винесла рішення щодо переведення науковопедагогічного працівника на більш високу посаду, керівник вузу розглядає його 
SCIENTIFIC APPROACHES IN JURISPRUDENCE

тільки в разі відповідності цього працівника кваліфікаційним вимогам до запропонованої посади.

У разі винесення атестаційною комісією рішення щодо невідповідності науково-педагогічного працівника займаній посаді, керівник може протягом двох місяців 3 дня затвердження результатів атестації Вченою радою запропонувати йому переведення на посаду, що відповідає його кваліфікації. У разі незгоди працівника 3 таким переведенням, 3 ним може бути розірвано трудовий договір відповідно до п. 2 ст. 40 Кодексу законів про працю України. Рішення керівника вузу щодо розірвання трудового договору за результатами атестації може бути оскаржене в суді відповідно до порядку розгляду індивідуальних трудових спорів [133]. Якщо в діяльності науково-педагогічного працівника виявлено ознаки недостатньої кваліфікації, що зафіксовані в акті про невиконання роботи, доповідній записці про допущені помилки, керівник вузу може призначити такому працівникові позачергову атестацію, проте не раніше року з моменту проведення останньої атестації (п. 9 Положення).

Керуючись розглянутим Положенням про атестацію, затвердженого Кабінетом Міністрів України, та іншими нормативно-правовими актами, кожен вищий навчальний заклад приймає своє положення про проведення атестації, в якому повинен уточнюватись перелік тих, хто підлягає атестації у ВУЗі та визначається склад атестаційної комісії. У положенні перераховується те, що повинна містити характеристика працівника, наприклад, розгорнута оцінка професійних знань, навичок, досвіду, вмінь, компетентності, соціальнопсихологічних якостей, виконання посадових обов'язків та рекомендації попередньої атестації, інформацію про результати діяльності за період, що минув після останньої атестації.

Висновки. Атестація науково-педагогічних працівників $є$ одним 3 найважливіших елементів системи управління персоналом у закладі вищої освіти, дозволяє оцінити його якість з точки зору відповідності його цілям i стратегії підприємства. Нормативно-правова база, що лежить в основі 
атестаційного процесу, повинна постійно вдосконалюватися, щоб не відставати від тих природних процесів, які відбуваються в управлінні персоналом і розвитку суспільства в цілому. Поведінкові помилки, які відбувається під час проведення атестації і мають людську природу, повинні нейтралізуватися правилами, встановленими законом, що стоять на захисті інтересів слабшої сторони у трудових відносинах - працівника. 


\subsection{Legal mechanism for making environmentally significant decisions}

Overcoming the ecological crisis is possible only on the basis of the formation of a new type of relationship between human and nature, new approaches to management, broad public involvement in environmentally sound decisions, taking into account the interests of society in preserving the environment in the context of sustainable development paradigm.

In management theory, decision-making is considered the most important function of management, the result of which is the choice of the subject of management of the best alternative aimed at solving a particular management problem.

The vast majority of authors note that ultimately the full cycle of management can be reduced to two main stages of management: preparation and implementation of management decisions. However, within these stages, quite often still offer certain stages. Thus, as a rule, within preparation of administrative decisions allocate such stages: statement of a problem, selection of a problem, creation of information model of a problem situation, construction of conceptual model of a problem situation, ways of the decision of a problem [137].

The stage of making managerial decisions, according to M.F. Gonchar, includes the following stages: collection and processing of information on the problem situation necessary for decision-making; development of management decisions; verification of the management decision [138].

O. Bandurka believes that the whole process of preparation and decision-making of management goes through such general stages as obtaining information, analysis of collected information and decision-making [139].

O. Shelomovska identifies five stages of the management decision-making procedure:

- development of a management decision that provides for the diagnosis of the problem and an objective analysis of the situation; 
SCIENTIFIC APPROACHES IN JURISPRUDENCE

- formation of criteria for making management decisions;

- identifying alternatives to management decisions and assessing the level of risk of each alternative;

- decision-making (discussion of the draft decision, its approval, execution and issuance of an order for its implementation);

- implementation of the adopted management decision, control over its implementation and evaluation of results [140].

The position of V.V. Konoplyova deserves attention, he proposes to identify the following stages of management decisions:

- identification of problem situations;

- forecasting;

- planning;

- discussion of possible (alternative) options for management decisions;

- registration of the administrative decision;

- approval of management decisions;

- finalization of the draft management decision. At the same time, the author

points out that such elements of the procedure as collection, analysis and processing of information and control and supervision activities do not require their selection in separate stages, because they are available during the entire procedure of preparation and management decision-making. [141].

N.L. Guberskaya, researching the procedures for making and implementing management decisions in the field of higher education, believes that the most successful approach to the selection and analysis of the main elements of the management decision-making process is its structuring into three main stages:

1. Stage of preparation of the decision, which involves timely collection of information and objective analysis of the situation, identification and evaluation of problems that arise in this area, defining goals and objectives of management, and forecasting further development of the situation taking into account the main external and internal factors. The main stages of this phase of the procedure are as follows:

- stage of obtaining information and analysis of the situation; 
- stage of problem detection and analysis;

- stage of forecasting the situation.

2. Stage of development and decision-making, which involves the development and setting of goals (tasks), evaluation and testing of alternative solutions and activities of government agencies, selection and adoption of optimal management decisions. It should be emphasized that ensuring high efficiency and effectiveness of management decision-making in the field of higher education at this stage requires identifying in the administrative activities of government and local government creativity, initiative, search and application of new methods and techniques of management decisions, use as experience in this activity, and modern foreign achievements of research activity on the order of development and acceptance of administrative decisions in the educational sphere. The main stages of this stage include the following:

- goal(priorities) setting stage;

- stage of developing options (alternatives) for management decisions;

- stage of choosing and making the optimal management decision.

3. The stage of implementation of the decision, which involves the direct implementation of the management decision, monitoring its implementation and evaluation of results. Defining the specifics and place of this stage of the administrative procedure, we should agree with the remark of O. Shelomovska, who emphasizes that since the procedure of development and implementation of management decisions requires its high quality and efficiency, at all stages of this stage of this procedure special role should be given to operational monitoring and control, which provide an opportunity for timely and optimal administrative intervention in the functioning of the higher education system at various levels of government and thus increase the efficiency of its management. [142]. Modern scholars also note that the proper quality and effectiveness of this procedure in the field of higher education can be achieved only if a number of general requirements are taken into account, among which, in particular, the following should be distinguished: clear definition of the educational problem; expediency of costs (material, financial, time, human) to implement the decision; compliance of the solution implementation with indicators of quality, costs, 
terms, etc .; correspondence of the forecast of the theoretical model to the actual data on the basis of which it was developed; the social effect of the management decision and its consistency with the functioning of other subsystems of society [143]. The main stages of this phase of the procedure include the following:

- stage of organizing the implementation of management decisions;

- stage of managing the implementation of the decision;

- stage of evaluating the results of management decisions [142].

However, it should be noted that the preliminary analysis of the procedure for making management decisions, including environmental ones, applies to those decisions that are made in the form of administrative acts (individual legal acts), based on the achievements of management theory. These procedures are not properly regulated and unified at the level of current legislation of Ukraine. In fact, the absence of the Administrative Procedure Code in Ukraine prompts the resolution of the issue of the procedure for issuing an administrative act in the scientific field. Today, a number of laws of Ukraine establish "own" requirements for the procedure for issuing one or another type of administrative acts. These are, for example, the laws of Ukraine "On citizens' appeals", "On licensing of certain types of economic activity", the Code of Ukraine on Administrative Offenses, etc. In view of this, according to R. Melnyk and $\mathrm{V}$. Bevzenko, subjects of public administration during the preparation and issuance of administrative acts should take into account the principles of administrative procedures developed and approved by the Committee of Ministers of the Council. [144].

In most European countries there are effective codified acts on detailed regulation of procedures in the activities of executive and local governments in terms of their relations with individuals and legal entities (for example, in Germany there is the Law on Administrative Procedure, in the Republic of Austria - the General Law on Administrative Procedure, in Poland - the Code of Administrative Procedure, etc.).

According to I. Paterilo, among the tools of public administration of European countries it is worth mentioning the category of administrative acts that affect the rights 
SCIENTIFIC APPROACHES IN JURISPRUDENCE

of a significant number of people, such as administrative acts on which large infrastructure projects are implemented: airport construction, highway and the like. Such projects, accordingly, affect the interests of individuals, and therefore requires the existence of perfect and balanced procedures for issuing these acts [144]. In view of this, the author notes, the Committee of Ministers of the Council of Europe adopted a recommendation of 17 September 1987 № $\mathrm{R}$ (87) 16 on administrative procedures affecting the rights of a significant number of persons, bearing in mind the following categories of persons :

- a large number of persons to whom administrative acts are addressed (persons of the first category);

- a large number of persons whose personal rights, freedoms or interests may be affected by an administrative act, even if it does not concern them (persons of the second category);

- a large number of persons who, under national law, have the right to declare a certain collective interest, which may be affected by an administrative act (persons of the third category) [145].

This document enshrines two categories of basic principles in the immediate field:

1) the principles used to adopt and monitor the above-mentioned administrative acts. These include the following requirements:

- if the competent authority proposes to adopt such an administrative act, the persons concerned must be duly informed and provided with such factors as will enable them to assess the possible consequences of that act for their rights, freedoms and interests.;

- taking into account the subject matter and consequences of the proposed administrative act, the interests represented, the status or number of persons concerned or the need to ensure effective management, the competent authority may decide to appoint one or joint representatives at all or some stages of the procedure; persons of the third category represent associations or organizations; 
- at the request of persons of the first category, in accordance with such representative arrangements as may be imposed on them, persons of other categories must have adequate access to all available factors affecting the adoption of the act;

- taking into account the subject matter and consequences of the proposed administrative act, the interests represented, the status or number of persons concerned, or the need to ensure effective governance, the competent authority may decide that the participation procedure will continue in one or more of the following forms: written comments; closed or opened hearing; representation in the advisory body of the competent authority. If the chosen procedure is a procedure for the representation of relevant persons in the advisory body, persons of the first category and, in accordance with the representative arrangements, persons of the second category also have the right to provide facts and arguments and (in certain cases) available evidence;

- the competent authority must take into account the facts, arguments and evidence provided by the persons concerned during the participation procedure;

- the administrative act must be made public. The public notice should indicate, if it does not contain this information, how the persons concerned can access the main conclusions arising from the procedure; motives on which the administrative act is based; information on the usual remedies against administrative acts and the time limits within which they must be used. Persons of the first category must be personally notified of the administrative act and its motives. The reasons may be contained in the act itself or be communicated to these persons in writing at their request within a certain period of time. These persons are also provided with information on the usual means and methods of legal protection against the act and the terms of their use;

- the administrative act must be subject to review by a court or other independent body. Such control does not preclude prior control by the administrative body. If the control procedure involves a large number of persons, the court or other controlling body may, having a certain relation to the rights and interests of the parties, according to the basic principles, take various steps to improve the procedure (for example, requiring participants with common interests to choose one or common representatives, 
to hear and finally resolve appeals, to make notifications by public announcement) [145];

2) Principles that should protect the persons concerned if an administrative act may have consequences in the territory of a neighboring state. Such rules include the following provisions:

- if an administrative act may affect the rights, freedoms or interests of a neighboring State, the administrative participation procedure set out in the basic principles must be made available to the persons concerned in that State on a nondiscriminatory basis;

- access to the control procedure must be ensured without discrimination on the grounds of nationality or residence;

- access to the administrative participation procedure and the control procedure may be subject to the principles of reciprocity $[145,146]$.

In the context of preparing for environmental decisions in the form of administrative acts, it should be emphasized that in addition to the above-mentioned recommendations of the Committee of Ministers of the Council of Europe, member states should be guided by special laws of Ukraine, including the Law of Ukraine on "Environmental Impact Assessment" etc.

In our opinion, although environmentally significant decisions are mostly made in the form of an administrative act (individual legal act), the possibility of making environmentally significant decisions in the form of regulations cannot be ruled out. According to VP Tymoschuk, the most problematic is the solution of the issue of "issuing regulations". At first glance, the difference between these activities of the authorities is primarily that the adoption of an administrative act has the task of resolving the individual life situation and applies to specific individuals and / or legal entities. Instead, the issuance of a normative act is aimed at resolving an indefinite number of cases and concerns an indefinite number of persons. [147]. From this point of view, even if the issuance of regulations by the executive is carried out in the order of so-called "delegated legislation", the relevant bodies (usually the Cabinet and the 
Ministry) in this case do not act as administrative bodies, but in fact as a legislator. In any case, it is necessary to fundamentally distinguish between law-making (rulemaking) and law enforcement, and try to avoid combining these activities in one institution. [147].

Despite the debatable normative function of executive bodies, the fact is that they perform such functions. Local self-government bodies are also endowed with rulemaking powers, namely councils as representative bodies of local self-government.

In general, when it comes to the procedure for the adoption of regulations by executive authorities or local governments, the procedure for preparation, review and adoption of regulations is determined by the body that ultimately adopts the regulation, taking into account the rules that may be in the regulations. legal act of higher legal force.

In 2010, the People's Deputy of Ukraine Yu.R. Miroshnychenko prepared a bill "On regulations" [148], which proposed, inter alia, to regulate the procedure for adopting regulations. However, the bill received a negative opinion from the Main Scientific and Expert Department, including on the procedure for adopting regulations. According to experts, the need to include in the text of the draft a list of stages of the rule-making process (Article 26) is questionable. This issue is not subject to legislative regulation and should be addressed at the doctrinal level in methodological manuals on lawmaking. Moreover, the laws on regulations of many foreign states do not establish a corresponding list at all, but this fact in no way impairs the legislative regulation of the rule-making process. The inexpediency of establishing the relevant list is evidenced by the fact that all the stages of the rule-making process included in it in accordance with Article 26 are optional (the wording "may consist of such (...) stages" is used). However, this provision is not true and does not comply with a number of other provisions of the project, the content of which part of these stages is mandatory for all regulations[149]. The revised draft law on normative legal acts submitted for second reading in 2012 did not eliminate the fundamental shortcomings of the previous version of the draft law, as evidenced by the conclusion of the Verkhovna Rada Committee of 
September 26, 2012 and the remarks of the Main Legal Department of October 15, 2012.

Nevertheless, the text of the draft law submitted for the second reading proposes the following procedure for the preparation and adoption (publication) of regulations:

1) planning the development of a legal act;

2) submission of a rule-making proposal and preparation of a draft normative legal act;

3) examination of the draft legal act;

4) introduction of the project of the regulatory legal act of the subject of normsetting;

5) consideration of the draft normative legal act by the subject of rule-making;

6) adoption (publication) of a normative legal act;

7) state registration of a legal act;

8) entry into force of the regulatory legal act;

9) introduction of a normative legal act into action.

Without going into a discussion about the importance and expediency of certain stages of the adoption of regulations, we consider it necessary to support the position of V.O. Khomenko said that after the text of the draft is prepared, it should be discussed among all stakeholders, who, after reviewing its content, can submit their proposals for addition, amendment or cancellation. In fact, at the stage of discussing the project, it is advisable to interact with members of the public, on which the decision will be directed. This will, first of all, involve more specialists in the development of the draft regulation, which will have a positive impact on the quality of the decision, as there will be more opportunities to obtain a balanced document that takes into account the interests of all stakeholders [150].

In general, the preparation and adoption of environmentally significant decisions as a management process should be based on certain principles, among which, in 
particular, R.Sh. Ivankov considers the following, which are important in the context of our study - the continuity of the management process and the sequence of decisions. According to the scientist, environmental management is a process of achieving the ultimate goal - safe for life and health of citizens of the environment, compliance with environmental legislation by all subjects. The sequence is expressed in the fact that the decisions made must be logically interconnected, follow from each other, with their help the ultimate goal must be achieved. Inconsistency of decisions, uncertainty of final results negatively affect the management processes. 


\subsection{Ensuring national security in a conflict society: processes and mechanisms of transitional justice}

The issue of ensuring national security in societies in a state of armed conflict is becoming relevant for the respective states among the priorities of domestic and foreign policy. Addressing these issues requires non-standard approaches in terms of organization of work of a state mechanism, consolidation of efforts of all stakeholders, and the focus of a civil society.

After the two world wars, the international community worked out a number of recommendations of the maintenance of international peace and security ${ }^{15}$, prevention and abolition of war, prohibition of propaganda for war and so on ${ }^{16}$. In the Charter, The United Nations sets out the fundamental principle of reliance on the peaceful settlement of disputes and the peaceful resolution of conflict.

Despite all efforts, the issue of armed conflicts in the world has not yet been resolved. Sierra Leone ${ }^{17}$, Rwanda ${ }^{18}$, Sudan ${ }^{19}$ and other countries of the African continent ${ }^{20}$, which have had or are having active armed conflicts; Croatia ${ }^{21}{ }^{22}$, Bosnia

\footnotetext{
${ }^{15}$ Bytyak Y., Yakovyuk I., Tragniuk O., Komarova T., Shestopal S. (2017). The state sovereignty and sovereign rights: The correlation problem. Man in India, 97(23), 577-588. URL:

http://dspace.nlu.edu.ua/bitstream/123456789/13482/1/Bytyak_Yakovyuk_Tragniuk_Komarova_Shestopal_577-588.pdf [accessed 19 October 2020] [in Eng.]

16 Яковюк I. (2003). Історичні передумови і основні етапи європейської інтеграції. Вісник Академії правових наук України, 4 , 82-92.

${ }^{17}$ Menzel A. (2020). The pressures of getting it right: Expertise and victims' voices in the work of the Sierra Leone Truth and Reconciliation Commission (TRC). International Journal of Transitional Justice, Oxford University Press (OUP). URL: https://academic.oup.com/journals/pages/open_access/funder_policies/chorus/standard_publication_model [accessed 19 October 2020]. DOI: https://doi.org/10.1093/ijtj/ijaa011 [in Eng.]

${ }^{18}$ Human Rights Watch, Genocide, War Crimes and Crimes Against Humanity: A Digest of the Case Law of the International Criminal Tribunal for Rwanda, 15 January 2010. URL: https://www.refworld.org/docid/4b5438802.html [accessed 19 October 2020] [in Eng.]

${ }^{19}$ Carolan G. (2020). Transition Without Transformation: The Legacy of Sudan's Comprehensive Peace Agreementю International Journal of Transitional Justice, Oxford University Press (OUP). URL: https://academic.oup.com/journals/pages/open_access/funder_policies/chorus/standard_publication_model. [accessed 19 October 2020]. DOI: https://doi.org/-10.1093/ijtj/ijaa010 [in Eng.]

${ }^{20}$ Beresford A., Wand D. (2020). Understanding bricolage in norm development: South Africa, the International Criminal Court, and the contested politics of transitional justice. Review of International Studies, Cambridge University Press (CUP), 1-21. DOI: https://doi.org/10.1017/s0260210520000224 [in Eng.]

${ }^{21}$ Sokolić I. (2016). Researching norms, narratives, and transitional justice: focus group methodology in post-conflict Croatia. Cambridge University Press (CUP). Nationalities Papers. Volume 6, 932-949. URL: https://www.cambridge.org/core/journals/nationalities-papers/article/researching-normsnarratives-and-transitional-justice-focus-group-methodology-in-postconflict-croatia/49C54295C7C41E14E24F9E7D13C9A3BF [accessed 19 October 2020] DOI: https://doi.org/10.1080/00905992.2016.1183605 [in Eng.]

${ }_{22}$ Cvikic S. (2019). Deconstruction of 'scientifically based injustices': About post-war traumatized populations of 'spoilers' in Croatia. National Library of Serbia. Sociologija Volume 61, Issue Suppl. 1, 697-717. URL: http://www.doiserbia.nb.rs/Article.aspx?ID=0038031819697C\#.X41EStAzY2x [accessed 19 October 2020]. DOI: https://doi.org/10.2298/SOC19S1697C [in Eng.]
} 
and Herzegovina ${ }^{23}$ Colombia $^{24}$, Syria ${ }^{25}$ - this is by no means an exhaustive list of those states that have faced the problems of conflict and post-conflict societies. It means that despite the efforts of the international community, establishment of a large number of humanitarian organizations, adoption of international norms in this area, armed conflicts cannot be avoided.

However, the analysis of the course and consequences of conflicts allow us to identify and form already tested in practice concepts about resumption of sovereignty, territorial integrity, national security, transition from conflict to post-conflict societies ${ }^{26}$. The issue of the functioning of law enforcement agencies and the judiciary of countries where long-term and stable peace has been restored, or the armed conflict has entered a phase of cessation of active armed confrontation or end of active hostilities, should be given special attention ${ }^{27}$. After all, armed conflicts are usually related to violations of human rights, laws and customs of war, the use of prohibited or restricted methods and means of armed conflict, and other not typical to peacetime negative consequences.

Summarizing the conclusions and recommendations of experts, the concept of transitional justice is of paramount importance for conflict and post-conflict societies. Recent years have seen an increased focus by the United Nations on questions of transitional justice and the rule of law in conflict and post-conflict societies, yielding important lessons for our future activities ${ }^{28}$.

Despite the name of the transitional justice system, there is no limit to judicial proceedings. The relevant concept includes non-judicial components (hybrid mechanisms, educational processes, the establishment of truth through quasi-judicial

\footnotetext{
${ }^{23}$ Clark J.-N. (2020). Storytelling, resilience and transitional justice: Reversing narrative social bulimia. Theoretical Criminology, SAGE Publications. URL: https://journals.sagepub.com/doi/10.1177/1362480620933230 [accessed 19 October 2020]. DOI: https://doi.org/10.1177/1362480620933230 [in Eng.]

${ }^{24}$ Clark J. N. (2020). Body Memories as a Neglected Legacy of Human Rights Abuses: Exploring Their Significance for Transitional Justice. SAGE Publications. Social \& Legal Studies. URL: https://journals.sagepub.com/doi/10.1177/0964663920962556 [accessed 19 October 2020]. DOI: https://doi.org/10.1177/0964663920962556 [in Eng.]

${ }_{25}$ Jazairi R. (2015). Transitional Justice in Syria: The Role and Contribution of Syrian Refugees and Displaced Persons. Middle East Law and Governance. Brill. Vol. 7, issue 3, 336-359. DOI: https://doi.org/10.1163/18763375-00703002 [in Eng.]

26 Червякова О.В. (2020). Відповідальність за воєнні злочини: через перехідне правосуддя до сталого миру та безпеки України. Проблеми законності. Вип. 15, 161-172. URL: http://plaw.nlu.edu.ua/article/view/208602/213553 [accessed 19 October 2020]. DOI: https://doi.org/10.21564/2414-990x.150.208602 [in Ukr.]

27 Червякова О. В. (2020). Відповідальність за воєнні злочини: механізми та процеси відновлення суверенітету та безпеки України. Форум Права, 61(2). 150-162. URL: http://forumprava.pp.ua/2020-n-2.html [accessed 19 October 2020].DOI: http://doi.org/10.5281/zenodo.3883835 [in Ukr.].

${ }^{28}$ The rule of law and transitional justice in conflict and post-conflict societies: Report of the Secretary-General (Distr.: General, 23 August 2004, S/2004/616) URL: https://www.securitycouncilreport.org/atf/cf/\%7B65BFCF9B-6D27-4E9C-8CD3- 
institutions etc.). As Colleen Murphy has proved, transitional justice refers to the process of dealing with human rights abuses committed during the course of ongoing conflict or repression, where such processes are established as a society aims to move toward a better state, and where a constitutive element of that better state includes democracy $^{29}$.

Paragraph 8 of the Report of the Secretary-General of the United Nations «The rule of law and transitional justice in conflict and post-conflict societies» includes a definition "transitional justice": comprises "the full range of processes and mechanisms associated with a society's attempts to come to terms with a legacy of large-scale past abuses, in order to ensure accountability, serve justice and achieve reconciliation. These may include both judicial and non-judicial mechanisms, with differing levels of international involvement (or none at all) and individual prosecutions, reparations, truth-seeking, institutional reform, vetting and dismissals, or a combination there of ${ }^{30}$. As we can see, for countries in armed conflict (international or non-international), world's leading experts emphasize the need to focus on the responsibility of persons who have violated the law; on the realization of the right to the truth; on reparations and institutional changes to prevent such conflict from ever happening again.

If we consider these components separately, then for individual prosecutions the rule should be the inevitability of punishment for such grave crimes, which are of concern to the entire international community, «threaten the peace, security and wellbeing of the world $»^{31}$. In our days the most serious crimes of concern to the international community as a whole include (a) the crime of genocide; (b) crimes against humanity; (c) war crimes; (d) the crime of aggression. These crimes are within the jurisdiction of the International Criminal Court. Their list is defined in the Rome Statute, which is the basis for the functioning of this international institution with universal jurisdiction and the principle of complementarity in their work. By adopting

29 Murphy C. (2020). Religion \& Transitional Justice. Daedalus, MIT Press - Journals, r. № 3, 185-200. DOI: https://doi.org/10.1162/daed_a 01811 [in Eng.]

${ }^{30}$ The rule of law and transitional justice in conflict and post-conflict societies: Report of the Secretary-General (Distr.: General, 23 August 2004 , S/2004/616). URL: $\quad$ https://www.securitycouncilreport.org/atf/cf/\%7B65BFCF9B-6D27-4E9C-8CD3CF6E4FF96FF9\%7D/PCS\%20S\%202004\%20616.pdf [accessed 19 October 2020]. [in Eng.]

${ }^{31}$ Rome Statute of the International Criminal Court (Rome, 17 July 1998). URL: https://www.icc-cpi.int/resource-library/documents/rs-eng.pdf [accessed 19 October 2020]. [in Eng.] 
this Statute, the States Parties affirmed «the most serious crimes of concern to the international community as a whole must not go unpunished and that their effective prosecution must be ensured by taking measures at the national level and by enhancing international cooperation ${ }^{32}$. The analysis of this position shows that the international community has identified those crimes for which the perpetrator cannot be released from responsibility and punishment. And this rule applies to all international crimes.

The concept of «international crimes» for the time being covers the abovementioned crimes under art. 5 of the Rome Statute ${ }^{33}$. However, with the development of international criminal law, the list of international crimes could be expanded ${ }^{34}$. Currently, "candidates" for international crimes which will be considered within the jurisdiction of the International Criminal Court, for example, terrorism ${ }^{35}$, slavery and the slave trade, and some other crimes of international nature ${ }^{36}$.

The conclusion on the inevitability of punishment and responsibility for international crimes is of paramount importance for the formation, implementation and coordination of the concept of transitional justice. It means that the amnesty and pardon for this category of crime cannot be raised in the negotiations between the parties to the conflict and in negotiating peace agreements.

As for truth-seeking, the parties to an armed conflict should know the historical truth about the conflict, its scale and consequences. In particular, Additional Protocol (I) to the Geneva Conventions regulates in art. 32 the right of families to know the fate of their relatives, art. 33 contains the obligation of search for the persons who have been reported missing, transmit all relevant information concerning such persons in order to facilitate searches ${ }^{37}$. The right of a person "to know the truth regarding the

\footnotetext{
${ }^{32}$ Rome Statute of the International Criminal Court (Rome, 17 July 1998). URL: https://www.icc-cpi.int/resource-library/documents/rs-eng.pdf [accessed 19 October 2020]. [in Eng.]

${ }^{33}$ Rome Statute of the International Criminal Court (Rome, 17 July 1998). URL: https://www.icc-cpi.int/resource-library/documents/rs-eng.pdf [accessed 19 October 2020]. [in Eng.]

34 Червякова О. В. Проблеми та наслідки визнання Україною юрисдикції міжнародного кримінального суду. Теоретичні питання юриспруденції і проблеми правозастосування: виклики XXI століття : тези доп. учасників III Всеукр. наук.-практ. конф. (Харків, 19 черв. 2020 р.); Наук.- дослід. ін-т публ. політики і соц. наук. Харків: НДІ ППСН, 2020. 236 c. C. 227-230. URL: https://pp-ss.pro/wp-

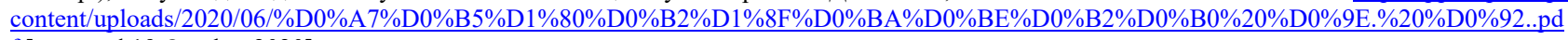
f [accessed 19 October 2020].

${ }^{35}$ Sopilko, I. N., Medvedieva, M. O., Guliiev, A. G., Bilotsky, S. D., Bukhanevych, O. N., Sirokha, D. I., \& Terekhova, T. A. (2018). International Terrorism and Massmedia. Journal of Legal, Ethical and Regulatory Issues, 21(2), 1-10.

${ }^{36}$ Sirokha, D., Felyk, V., Podorozhnii, Y., Podorozhnii, A. (2020). Basic aspects of the compliance with discipline and legitimacy within the official activities of police. Amazonia Investiga, 9(25), 487-492.

${ }^{37}$ Protocol Additional to the Geneva Conventions of 12 August 1949, and relating to the Protection of Victims of International Armed Conflicts (Protocol I), 8 June 1977. URL:https://www.icrc.org/en/doc/assets/files/other/icrc_002_0321.pdf [accessed 19 October 2020].
} 
circumstances of the enforced disappearance, the progress and results of the investigation and the fate of the disappeared person" is contained in Art. 24 of International Convention for the Protection of All Persons from Enforced Disappearance $^{38}$. In considering this component of transitional justice, caution should be exercised against substituting truth-seeking and historically documenting. The right to the truth is not only the right to receive information about certain crimes, circumstances of the offence and so on. It is an obligation of the state to provide free access to the information about an armed conflict, to conduct educational and training programs, to organize the work of Commission for Truth and Justice.

Without being a court, truth commissions as quasi-judicial institutions can be an effective element of transitional justice not only in terms of establishing the truth. To this end, the work of truth commissions should be linked to other institutions that embody other elements of transitional justice. An example is the experience of the Special Justice for Peace in the Colombian transitional justice mechanism ${ }^{39}$.

Such experience is of interest to other countries, with reservation about the concept of transitional justice which should be individualized in the light of specific circumstances. For example, for Ukraine ${ }^{40}$, the experience of transitional justice in Colombia can be considered in resolving amnesty issues, organizing the work of commission for truth and justice and others ${ }^{41}$. However, one should understand the nature of the conflict, which in Colombia is purely internal: from 1964 to 2016 there was a civil war against the government involving the FARC and other illegal military groups $^{42}$.

\footnotetext{
38 International Convention for the Protection of All Persons from Enforced Disappearance. URL: https://www.ohchr.org/en/hrbodies/ced/pages/conventionced.aspx [accessed 19 October 2020].

${ }^{39}$ Muñoz M. G., Serralvo J. (2019). International humanitarian law in Colombia: Going a step beyond. Cambridge University Press (CUP). International Review of the Red Cross. Volume 912, 1117-1147.

URL: https://www.cambridge.org/core/journals/international-review-of-the-red-cross/article/international-humanitarian-law-in-colombiagoing-a-step-beyond/4A4D4C6410CDFFC9D2903C997F2E032B [accessed 19 October 2020]. DOI: https://doi.org/10.1017/s1816383120000181

${ }^{40}$ Getman, A. P., \& Yakoviyk, I. V. (2019). National Security Strategy of Ukraine: History of Belated Reforms. Probs. Legality, 147, 8. URL:http://plaw.nlu.edu.ua/article/view/186338. DOI: https://doi.org/10.21564/2414-990x [accessed 19 October 2020] [in Eng.]

${ }^{41}$ Іншин, М. І., Сіроха, Д. І. (2015). Соціальний захист в Україні: сутність, проблеми та перспективи. Актуальні проблеми сочіального права: науково-практичний посібник. Випуск II, 14.

${ }^{42}$ Giraldo M. L., Tobón D. J. (2020) Personal archives and transitional justice in Colombia: the Fonds of Fabiola Lalinde and Mario Agudelo. Informa UK Limited. The International Journal of Human Rights, 1-21. URL:

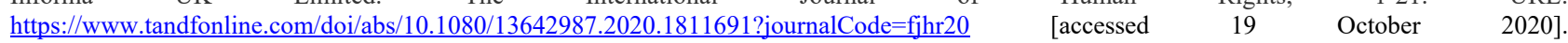
DOI: https://doi.org/10.1080/13642987.2020.1811691.
} 
The Tribunal for Peace, the Special Jurisdiction for Peace and the National Search Commission for the Disappeared have been set up in Colombia to deal with liability issues $^{43}$. They constitute the justice components of a Comprehensive System of Truth, Justice, Reparation, and Non-Repetition (SIVJRNR) that seeks to satisfy the victims' rights to learn the full truth of past events, receive reparations, and obtain guarantees of non-repetition. The system additionally aims to promote the acknowledgement of the responsibility of all who participated in the conflict-directly or indirectly; to construct historical memory; and to reconcile Colombian society in order to move toward a future of civility and peaceful coexistence ${ }^{44}$. And these institutions cooperated with each other, in compliance with the principle of no amnesty and pardon for war criminals and those guilty of crimes against humanity ${ }^{45}$. At the same time, if such persons cooperated with the Special Justice for Peace, the term of their punishment could be changed in the direction of reduction. Under what conditions? Through demilitarization, clear indication of the motives, accomplices, circumstances of the crime, as well as in case of reparation (compensation to victims).

Among the positive points there are the following ones. 1. SIVJRNR made possible to determine the amount of losses of human life, destruction of property and other real facts of the historical past, including the interaction of politicians and businessmen with the insurgents. 2. Victims exercised their right to the truth: they could be present in open meetings, at least in a separate room, to ask questions.

However, this cooperation has some negative experiences. 1. The victims expected more. 2. Violence continues. 3. Law enforcement agencies were in no hurry to investigate the involvement of officials in the armed conflict.

As for the experience of amnesty, it was granted to those who pleaded guilty in Colombia. And this is the key point of any amnesty - to plead guilty. Secondly, these people, who are eligible for amnesty, didn't have just to lay down their arms, but to

${ }^{43}$ Cronin-Furman K., Krystalli R. (2020). The things they carry: Victims' documentation of forced disappearance in Colombia and Sri Lanka. SAGE Publications. European Journal of International Relations.URL: https://journals.sagepub.com/doi/10.1177/1354066120946479 [accessed 19 October 2020]. DOI: https://doi.org/10.1177/1354066120946479

${ }^{44}$ The Special Jurisdiction for Peace in Colombia: Recommendations for the Selection of Judges of the Chambers and Divisions of the Tribunal for Peace. URL: http://www.dplf.org/sites/default/files/the special jurisdiction_peace colombia web 0603 2016 0.pdf [accessed 19 October 2020].

45 Guerrero F., Aristizabal L.-L. (2020). Images and Memory: Religiosity and Sacrifice - The Cases of Tierralta, Trujillo and Arenillo in Colombia. International Journal of Transitional Justice. Volume 14. Issue 1, 35-55. URL: https://academic.oup.com/ijit/articleabstract/14/1/35/5803882?redirectedFrom=fulltext [accessed 19 October 2020]. DOI: https://doi.org/10.1093/ijtj/ijz030 
guarantee that they would never take up arms again in their lives. And the third, very interesting aspect, which I think would be useful to consider, is the mandatory participation in the payment of reparations to the victims.

With regard to institutional reforms, in 2017, in the Report of the UN General Assembly (Human Rights Council), the Special Rapporteur on the promotion of truth, justice, reparation and guarantees of non-recurrence argues that "transitional justice must include a significant dimension of institution-building. Because building institutions is a long-term process, however, he also emphasizes the importance of steps to increase the responsiveness of transitional justice measures. He insists on the importance of responses that are suited to context and to well-defined ends. In the report, the Special Rapporteur refers to improvements in witness protection, prioritization strategies and measures to strengthen civil society as initiatives that would indicate responsiveness and yet offer the possibility of sustained action in the areas of truth, justice, reparation and nonrecurrence" 46 . There are the institutional reforms that make it possible to bring about such changes that their implementation ensures the sustainability of peace. The non-repetition of the conflict is guaranteed through inspections and dismissals personnel in the security and defense sector, the justice system.

${ }^{46}$ Report of the Special Rapporteur on the promotion of truth, justice, reparation and guarantees of non-recurrence (Distr.: General, 21 August 2017 , A/HRC/36/50). URL: https://undocs.org/A/HRC/36/50 [accessed 19 October 2020]. 


\subsection{Demilitarized zones in international law}

International Public Law distinguishes between general and special regimes of territories ${ }^{47}{ }^{48}$. The regime of demilitarized zones ${ }^{49}$ in the educational and scientific literature 505152 is considered as a special regime of territories. Such zones ("zones of peace", "neutral zones", "nuclear-free zones", etc.) have a special status and are established by treaties or on the basis of decisions of international organizations, in particular UN Security Council resolutions.

These territories may be state-owned, but the special legal regime established within them limits certain sovereign rights of the state to use the demilitarized zone for military purposes.

International legal practice of the second half of the twentieth century demonstrated the significant effectiveness of the formation of demilitarized territories ("peace zones", "neutral zones", "nuclear-free zones", etc.) in maintaining international peace and security. Such territories formed certain areas free from all types of military activity (location of armed forces and weapons, formation of military bases, military maneuvers and exercises) and / or territorial encroachments of many influential countries, which were often in the opposite trenches of the "Cold War".

In the early 1990 s, the formation of demilitarized territories was declared as one of the most effective means of preventive diplomacy, which, in conjunction with peacekeeping, should help both prevent and resolve armed conflicts ${ }^{53}$. Thus, a new

\footnotetext{
47 Антипенко В., Тимченко Л.. Бєглий О. (2012) Міжнародне публічне право: підручник у 3 т. за заг. ред. та ін. Київ : НАУ. Т. 1.

${ }^{48}$ Мицика В., Буроменський М., Гнатовський М. (2018). Міжнародне публічне право : підручник у 2 т. Т. 2. Харків : Право. С. 340

${ }^{49}$ Ibid.

50 Оппенгейм Л. (1950). Международное право. Том 2. Война. Нейтралитет. Москва : Изд-во иностр. лит.

51 Броунли, Я. (1977). Международное право: в 2-х кн. Москва : Прогресс.

52 Клименко, Б. (1963). Демилитаризация и нейтрализация в международном праве. Москва : Ин-т междунар. отношений.

${ }^{53}$ An Agenda for Peace. Preventive diplomacy, peacemaking and peace-keeping. Report of the SecretaryGeneral on June 17, 1992. $<$ https://www.un.org/ruleoflaw/blog/document/an-agenda-for-peace-preventivediplomacy-peacemaking-and-peace-keeping-report-of-the-secretary-general/> (accessed on 24/09/2020). [in English].
} 
practice of establishing demilitarized spaces between the conflicting parties in order to separate them, prevent attacks on each other and provide humanitarian assistance appeared.

The purpose of creating demilitarized spaces is as follows: first, to prevent armed conflict between states and reduce the risks of its occurrence in the future, second, to reduce the scale of existing armed conflict and, besides, to restore postwar relations. Demilitarized territories have their individual characteristics, the main of which is the prohibition of any military activity within the zone defined by the states.

The international legal regulation of their creation is carried out by the Additional Protocol of 1977 to the Geneva Conventions of August 12, 1949, concerning the protection of victims of international armed conflicts (Additional Protocol I), namely Art. $60^{54}$. Thus, this article defines the main conditions that the demilitarized zone must meet, in particular: "a) all combatants, as well as mobile weapons and mobile military equipment, must have been evacuated; b) no hostile use shall be made of fixed military installations or establishments; c) no acts of hostility shall be committed by the authorities or by the population; and d) any activity linked to the military effort must have ceased" ${ }^{\prime 5}$. Article 60 of Additional Protocol I sets out the minimum requirements to be met by a demilitarized zone. In particular, the parties to the international agreement specify the list of prohibited military activities, as well as determine who may be within the demilitarized zone (Part 3 of Article 60). In addition, the parties of international agreement determine the coordinates of the established zone and identification marks which are established on the ground (Part 5 of Article 60).

It should be noted that International Law distinguishes many different examples of demilitarization of space, including parts of land and sea areas, islands and archipelagos, free cities, straits and canals, rivers and seas. And all these examples have their own characteristics.

\footnotetext{
${ }^{54}$ Additional Protocol (1977) to the Geneva Conventions of August 12, 1949, concerning the protection of victims of international armed conflicts. $<\mathrm{https}$ ://www.icrc.org/ru/doc/ resources/documents/misc/treatiesadditional-protocol-1.htm $>$ (accessed on 24/09/2020). [in English].

${ }^{55}$ Ibid.
} 
Islands (Archipelagos). Thus, on the basis of the Convention on the Demilitarization of the Aland Islands of March 30, 1856, a special regime of this archipelago was established between Great Britain, France and the Russian Empire. The 1856 Convention contained two articles, one of which (Article 1) provided for an undertaking by the Russian Empire not to fortify the islands and not to place any military or naval structures in the future ${ }^{56}$.

Half a century later, the Convention for the Prohibition of the Fortification and Neutralization of the Åland Islands (hereinafter referred to as the 1921 Convention) $)^{57}$ was concluded under the auspices of the League of Nations in Geneva on October 20, 1921, which reaffirmed their status as established by the 1856 Convention. The 1921 Convention details the list of prohibited military activities and does not reduce it only to the destruction of fortifications and the prohibition of their construction in the future. The 1921 Convention includes the following activities in this list: Article 3 - military, naval and air bases and institutions, any facilities used for military purposes; Article 4 - military, naval, air forces of any state; production, transportation, export of weapons ${ }^{58}$. After the signing of the Paris Peace Treaty with Finland in 1947 by the victorious states in World War II, the Åland Islands retained their status, as evidenced by Art. 5 of the Agreement: "The Åland Islands must remain demilitarized in line with the current situation"59. Protocol 2 to the Treaty of Accession of Austria, Finland and Sweden to the European Union confirms "the special status of the Åland Islands under

\footnotetext{
${ }^{56}$ Convention on the demilitarization of the Åland Islands. Paris, 30 March 1856 (translation from the original french text). <http://www.kulturstiftelsen.ax/images/internationellaavtal/engelskaavtal.pdf $>$ (accessed on 24/09/2020). [in English].

${ }^{57}$ Convention relating to the Non-Fortification and Neutralisation of the Aaland Islands. Geneva on October 20, 1921. Treaty Series, League of Nations. (Vol. 9, p. 211-221).

$<$ https://treaties.un.org/doc/Publication/UNTS/LON/Volume\%209/v9.pdf $>$ (accessed on 24/09/2020). [in English].

58 Ibid.

${ }^{59}$ Treaties of Peace with Italy, Bulgaria, Hungary, Roumania and Finland. Paris, February 10, 1947. $<$ https://babel.hathitrust.org/cgi/pt?id=osu.32435066406612; view=1up;seq=231 $>($ accessed on 24/09/2020). [in English].
} 
International Law" ${ }^{\prime 60}$. This may indicate the formation of a customary rule ${ }^{61}$ on the recognition by EU member states of the special international legal status of the Åland Islands.

Another example, according to Art. 14 (1) of the Paris Peace Treaty with Italy of February 10, 1947 (hereinafter - the Agreement of 1947) demilitarized the Dodecanese Islands, including: Agathonisi, Astypalaia, Chalki, Kalymnos, Karpathos, Kasos, Leipsoi, Leros, Nisyros, Symi, Tilos, and Kastellorizo. However, Art. 14 (2) states that "islands must and will remain demilitarized"62. Also, the Agreement of 1947 provides for the demilitarization of the islands of Pelagoza (Part 2 of Article 11), Panteleria, the Pelagic Islands (Lampedusa, Lampione and Linoza) and Pianosa (in the Adriatic Sea) (Part 1 of Article 49). It should be emphasized that this treaty, in general, is of great historical significance, as it was the first agreement to define "demilitarization" at the universal level.

Thus, Chapter XIII, Part "D" discloses their content as follows: "For the purposes of this Treaty, the terms "demilitarization" and "demilitarized" shall mean the prohibition within this territory and territorial waters of all types of naval, military, airborne structures, fortifications and their armaments; artificial military, naval and naval air barriers, basing or staying, both permanent and temporary, of any part of the land, naval and air forces, military training in any form, and the production of military materials and equipment. This shall not prohibit a limited number of internal security personnel in charge of internal tasks, armed with weapons capable of being carried and used by one person, and the military training required for such personnel"63.

In addition, the Agreement of 1947 defines the types of military activities that it prohibits. In particular, Chapter XIII, entitled "Definitions", includes the following:

\footnotetext{
60 Treaty of Accession of Austria, Finland and Sweden (1994). $<$ https://eurlex.europa.eu/eli/treaty/acc_1994/act_1/pro_2/sign> (accessed on 24/09/2020). [in English].

${ }^{61}$ Щокін Ю. В. Міжнародно-правовий звичай: проблеми теорії і практики : монографія. Харків : Право, 2012. 454 c.

62 Treaty of Peace with Italy signed at Paris, on 10 February 1947. UNTS, Vol. 49, No. 747 $<$ https://treaties.un.org/doc/publication/unts/volume\%2049/v49.pdf $>$ (accessed on 24/09/2020). [in English]. ${ }^{63}$ Ibid.
} 
paragraph A "Naval Definitions"; item B "Definition of military, air-air, naval training"; Clause C "Definition and list of military materials and equipment" ${ }^{64}$.

Sea waterways (canals and straits). A well-known example is the demilitarization of the Bosphorus and Dardanelles. Thus, the Lausanne Convention on the Regime of Straits of July 24, 1923 was signed simultaneously with the Peace Agreement between, on the one hand, Great Britain, the French Republic, the Kingdom of Italy, the Empire of Japan, the Kingdom of Greece, the Kingdom of Romania, the Kingdom of Serbs, Croats and Slovenes and, on the other hand, Turkey from July 24, 1923 , and is part of this treaty.

In Art. 4 of the Convention provided for the demilitarization of certain areas on both shores of the Dardanelles and the Bosphorus, as well as the demilitarization of some islands in the Marmara and Aegean Seas, in particular, Mytilene, Chios, Samos, Nicaria ${ }^{65}$. Article 6 of the Convention stipulates that "there shall exist, in the demilitarised zones and islands, no fortifications, no permanent artillery organisation, no submarine engines of war other than submarine vessels, no military aerial organisation, and no naval base" 66 . In addition, this article includes the following requirements: "No armed forces shall be stationed in the demilitarised zones and islands except the police and gendarmerie forces necessary for the maintenance of order; the armament of such forces will be composed only of revolvers, swords, rifles and four Lewis guns per hundred men, and will exclude any artillery. In the territorial waters of the demilitarised zones and islands, there shall exist no submarine engines of war other than submarine vessels" 67 .

In order to comply with the regime of these demilitarized zones, the Convention provided for the establishment of a Commission of the Straits, which would exercise supervision, composed of representatives from Turkey, France, Britain, Italy, Japan, Bulgaria, Greece, Romania, Russia and Yugoslavia (Art. 12 of the Convention). In

\footnotetext{
${ }^{64}$ Ibid.

${ }^{65}$ Convention Relating to the Régime of the Straits $<$ http://www.mfa.gov.tr/ii_-convention-relating-to-theregime-of-the-straits.en.mfa $>$ (accessed on 24/09/2020). [in English].

${ }^{66}$ Ibid.

${ }^{67}$ Ibid.
} 
addition, Art. 18 provides for collective self-defense in the event of an act of war or threat of war that violates the regime of demilitarized zones ${ }^{68}$.

Also, in the international legal sphere you can find examples of demilitarization of channels. Thus, the Suez Canal on the basis of the Constantinople Convention of October 29, 1888 was partially demilitarized, as provided for in Art. 7: "The Powers shall not keep any vessel of war in the waters of the Canal (including lake Timsah and the Bitter Lakes). Nevertheless, they may station vessel of war in the ports of access of Port Said and Suez, the number of which shall not exceed two for each power. This right shall not be exercised by belligerents" ${ }^{69}$.

Cities. There are several well-known in International Law examples of demilitarized free cities, in particular the Free City of Krakow ${ }^{70}$, Danzig ${ }^{71}$, and the Free Territory of Trieste ${ }^{72}$. For example, the demilitarization of the Free Territory of Trieste was carried out in 1947 on the basis of the Agreement of 1947 (Annex VI, Part 1, Article 3$)^{73}$. The conditions that this zone had to meet were provided for in parts 2, 3, 4 of Art. 3 of Annex VI to the 1947 Agreement, namely: "Part 2 No armed forces, other than by order of the Security Council, shall be in the Free Territory; Part 3 No paramilitary formations, manoeuvres or activities within the Free Territory shall be permitted; Part 4 The Government of the Free Territory shall not conclude or discuss any military agreements or commitments with any state" 74 .

Thus, another example of the demilitarization of space is the establishment of a special regime of the Rhine, in particular, Articles $42-44$ of the Treaty of Versailles

\footnotetext{
68 Ibid.

${ }^{69}$ Constantinople Convention October 29, 1888. <https://loveman.sdsu.edu/docs/1888C onstantinopleConventionon.pdf> (accessed on 24/09/2020). [in English].

${ }^{70}$ Acte du congrès de Vienne du 9 juin 1815 avec ses annexes. British and foreign state papers. 1815-1816, vol. 3 (compiled by the Librarian and Keeper of the papers, Foreign Office). <https:// books.google.co.uk/books?id =UY8AAAAAYAAJ\& pg=PA7\&hl=ru\#v=onepage\&q\&f=false>. (accessed on 24/09/2020). [in English].

71 The Versailles Treaty June 28, 1919: Part XV. <https://avalon.law.yale.edu/imt/partxv.asp>. (accessed on 24/09/2020). [in English].

72 Treaty of Peace with Italy signed at Paris, on 10 February 1947. UNTS, Vol. 49, No. 747 $<$ https://treaties.un.org/doc/publication/unts/volume\%2049/v49.pdf> (accessed on 24/09/2020). [in English].

73 Ibid.

74 Ibid.
} 
disclose the conditions to which this zone was to meet: "Germany was forbidden to maintain and build any fortifications both on the left bank of the Rhine and on the right bank along the line at a distance of $50 \mathrm{~km}$ from east to west of the Rhine"75.

In addition, Art. 43 states that within this zone it was forbidden to hold military formations both permanently and temporarily, to carry out military manoeuvres, mobilization measures ${ }^{76}$. In case of violation of the regime established by Art. 42-43, such behaviour could be considered as an act of hostility against the parties to the agreement and in general as an act against peace in the hole world ${ }^{77}$. Accordingly, the Versailles Peace Treaty of 1919 for the first time at the universal level provided for the creation of a demilitarized zone, namely, the Rhine.

Border areas. Thus, on the basis of the UN`s Security Council resolution of March 4, 1964 ${ }^{78}$, the UN Force (UNFICYP) created a demilitarized (buffer) zone in Cyprus, also called the "Green Line" along the city of Nicosia (paragraph 31$)^{79}$. Since the beginning of the conflict between Greek and Turkish Cypriots, the UN Force continue to monitor the buffer zone. In particular, the UN`s Security Council resolution of 30 January 2020 proclaimed the following: "Noting that the Government of Cyprus is agreed that in view of the prevailing conditions on the island it is necessary to keep the United Nations Peacekeeping Force in Cyprus (UNFICYP) beyond 31 January $2020^{1180}$.

Furthermore, the resolution stipulates that: "Expresses serious concern at the increased number of violations of the military status quo along the ceasefire lines, calls once more on the sides and all involved parties to respect UNFICYP's mandated

\footnotetext{
75 The Versailles Treaty June 28, 1919: Part XV. <https://avalon.law.yale.edu/imt/partxv.asp>. (accessed on 24/09/2020). [in English].

76 Ibid.

77 Ibid.

${ }^{78}$ Resolution adopted by the Security Council at its 1102nd meeting on 4 March 1964 [on establishment of the UN Peace-keeping Force in Cyprus].

$<$ https://digitallibrary.un.org/record/607947? In=en> (accessed on 24/09/2020). [in English].

${ }^{79}$ Report by Secretary-General on the United Nations operation in Cyprus S/5950 September 10, 1964. <https://digitallibrary.un.org/record/538507> (accessed on 24/09/2020). [in English].

${ }^{80}$ Resolution 2506 (2020) Adopted by the Security Council at its 8709th meeting, on 30 January 2020. <https://digitallibrary.un.org/record/3848947> (accessed on 24/09/2020). [in English].
} 
authority in, and delineation of, the buffer zone, urges the use of the 2018 United Nations aide-memoire by the sides to ensure peace and security in the buffer zone, and calls on the two sides to prevent unauthorised activities between the ceasefire lines"(par. 11) ${ }^{81}$. Thus, to date, the UN mission continues to monitor the situation in the Republic of Cyprus and its efforts to promote compliance with the buffer zone.

Another example of a border zone was the creation of a demilitarized space between North and South Vietnam under the Vietnam Ceasefire Agreement of July 20, 1954 (1954 Geneva Agreements). According to Art. 1 of the Agreement: "...a demilitarized zone shall be established on either side of the demarcation line, to a width of not more than $5 \mathrm{~km}$ from it, to act as a buffer zone and avoid any incidents which might result in the resumption of hostilities" ${ }^{82}$. In addition, Art. 6 defines the conditions to be met by the buffer zone, in particular: "No person, military or civilian, shall be permitted to cross the provisional military demarcation line unless specifically authorized to do so by the Joint Commission" ${ }^{83}$. However, such an example has proved its ineffectiveness as the regime in this area has been systematically violated by both sides of the conflict.

The analysis of the most well-known examples provides an opportunity to conclude that the legal regime of demilitarized territories is based on international agreements or decisions of international organizations, such as UN`s Security Council resolutions. While maintaining national jurisdiction in this territory (zone), military formations and new military facilities may not be located and maintained. Land, water and air can be demilitarized. The purpose of creating demilitarized zones is to create a safe zone free from all types of military activity and, thus, to prevent the occurrence of an armed conflict or to prevent its spread.

\footnotetext{
81 Ibid.

${ }^{82}$ Agreement on the Cessation of Hostilities in Viet-Nam 20 July 1954 <https://history.state.gov/historicaldocuments/frus1952-54v16/ch8> (accessed on 24/09/2020). [in English].

83 Ibid.
} 


\section{3 Право на справедливий суд: теорія i практика міжнародних контрольних органів у галузі прав людини}

Право на справедливий судовий розгляд $є$ одним із найважливіших складових захисту прав людини i процесуальних засобів забезпечення верховенства права. Право на справедливий і відкритий розгляд компетентним, незалежним і безстороннім судом, створеним на підставі закону, а також інші гарантії належного процесу є такими, що становлять невід’ємну частину підтверджених державами зобов'язань s3 людського виміру [199].

Означене право гарантовано у положеннях низки міжнародно-правових актів універсального і регіонального характеру з прав людини. Так, Загальною декларацією прав людини 1948 року (далі - Декларація 1948 року) проголошується право кожної людини на ефективне поновлення у правах компетентними національними судами у разі порушення iї основних прав, наданих їй конституцією або законом (ст. 8). Статтею 10 Декларації 1948 року визнано, що кожна людина, для визначення ii прав і обов'язків та для встановлення обгрунтованості пред'явленого їй кримінального обвинувачення, має право, на основі повної рівності, на те, щоб іiї справа була розглянута прилюдно і з додержанням усіх вимог справедливості незалежним і безстороннім судом (ст. 10) [200].

Стаття 14 Міжнародного пакту про громадянські і політичні права 1966 року (далі - Пакт 1966 року) також спрямована на забезпечення належного здійснення правосуддя і з цією метою гарантує низку конкретних прав [201]. Комітет з прав людини у своєму Зауваженні загального характеру № 32 $\mathrm{CCPR} / \mathrm{C} / \mathrm{GC} / 32$ акцентував увагу на тому, що стаття $14 €$ особливо складною за характером, поєднуючи в собі різноманітні гарантії, що різняться за сферою охоплення [202]. Так, відповідно до вказаної статті, всі особи є рівними перед судами і трибуналами. Кожен має право при розгляді будь-якого кримінального обвинувачення, висунутого проти нього, або при визначенні його прав i обов'язків у будь-якому цивільному процесі на справедливий і публічний розгляд його справи компетентним, незалежним i безстороннім судом, 
SCIENTIFIC APPROACHES IN JURISPRUDENCE

створеним на підставі закону. Преса і публіка можуть не допускатися на весь судовий розгляд або частину його з міркувань моралі, громадського порядку або національної безпеки в демократичному суспільстві або коли того вимагають інтереси приватного життя сторін, або - в тій мірі, в якій це, на думку суду, суворо необхідно, - за особливих обставин, коли публічність розгляду може зашкодити інтересам правосуддя; однак будь-яка судова постанова в кримінальній або цивільній справі повинна бути публічною, за винятком тих випадків, коли інтереси неповнолітніх вимагають іншого чи коли справа стосується матримоніальних спорів або опіки над дітьми (ст. 14). Частина 2 статті 14 Пакту закріплює, що кожен, кого обвинувачено у вчиненні кримінального правопорушення має право вважатися невинуватим, поки його вина не буде доведена згідно із законом. Крім цього, вказана стаття закріплює мінімальні гарантії особи, проти якої висунуто кримінальне обвинувачення, серед яких: право бути в терміновому порядку і детально поінформованим мовою, яку особа розуміє, про характер і підставу пред’явленого йому кримінального обвинувачення; мати достатній час і можливості для підготовки свого захисту і зноситися з обраним ним самим захисником; бути судимим без невиправданої затримки; бути судимим за його присутності і захищати себе особисто або за допомогою обраного ним захисника правову допомогу захисника; якщо особа не має захисника, бути повідомленим про це право і мати призначеного захисника в будь-якому випадку, коли інтереси правосуддя того вимагають, безоплатно, коли особа не має достатньо коштів для його оплати; допитувати свідків обвинувачення або мати право на те, щоб їх допитали, а також вимагати виклику і допиту його свідків на тих же умовах, які існують для свідків, що дають показання проти нього; отримувати безкоштовну допомогу перекладача, якщо особа не розуміє мови, яка використовується в суді, або не говорить цією мовою; не примушуватися до дачі свідчень проти самого себе чи до визнання себе винним.

Пакт 1966 року також гарантує, що кожен, кого засуджено за будь-який злочин, має право на те, щоб його засудження і вирок були переглянуті вищою 
SCIENTIFIC APPROACHES IN JURISPRUDENCE

судовою інстанцією згідно із законом. У тому випадку, якщо будь-яку особу остаточним рішенням було засуджено за кримінальний злочин і якщо винесений їй вирок був потім скасований або їй було даровано помилування на тій підставі, що будь-яка нова або нововиявлена обставина беззаперечно доводить наявність судової помилки, то ця особа, яка зазнала покарання в результаті такого засудження, отримує відшкодування згідно із законом, якщо не буде доведено, що зазначена невідома обставина не була свого часу виявлена виключно або частково з вини особи. Істотним є положенням Пакту, згідно з яким ніхто не повинен бути вдруге засуджений чи покараний за злочин, за який він уже був остаточно засуджений або виправданий відповідно до закону і кримінальнопроцесуального права кожної країни [203].

Крім того, Комітет з прав людини акцентує увагу на тому, що в якості зводу процесуальних гарантій стаття 14 Пакту 1966 року часто відіграє важливу роль у здійсненні інших гарантій, закріплених Пактом, які повинні враховуватися в контексті розгляду кримінальних обвинувачень i при визначенні прав та обов’язків особи в будь-якому цивільному процесі. Так, зокрема, з процесуальної точки зору важливе значення має зв'язок з правом на ефективний засіб правового захисту, передбачено в пункті 3 статті 2 Пакту, яке має дотримуватися в усіх випадках, коли порушена будь-яка з гарантій, передбачених у статті 14. У судових розглядах, підсумком яких може бути призначено покарання у вигляді смертної кари, ретельне дотримання гарантій справедливого судового розгляду є особливо значимим, оскільки прийняття такого рішення і виконання покарання в подальшому, з порушенням положень статті 14, представляє собою порушення права на життя (стаття 6 Пакту). Жорстоке поводження 3 особами, яким пред’явлено кримінальне обвинувачення, i здійснюється їх примус до дачі показів з визнанням провини під загрозою насильства, є порушенням як статті 7 Пакту 1966 року, яка забороняє тортури і жорстоке, нелюдське або таке, що принижує гідність, поводження, так і статті 14, що забороняє примус до давання свідчень проти самого себе чи до визнання себе винним. У тому випадку, якщо хто-небудь підозрюваний у скоєнні злочину і затриманий на підставі положень 
статті 9 Пакту звинувачується у скоєнні злочину, але справа судом не розглядається, можуть бути одночасно порушені заборони на невиправдану затримку судового розгляду, передбачені пунктом 3 статті 9 та пунктом 3 с) статті 14 Пакту.

Проведення кримінальних судових розглядів також може зачіпати здійснення і використання прав і гарантій Пакту, не пов’язаних зі статтею 14. Так, наприклад, не вирішення протягом декількох років питання про обвинувачення в кримінальному правопорушенні у вигляді дифамації, пред'явленому журналісту за опублікування декількох статей, в порушення пункту 3 с) статті 14, може ставити обвинуваченого в положення невизначеності i слугувати цілям залякування i тим самим чинити паралізуючий ефект, що неправомірно обмежує здійснення права на свободу вираження своєї думки (стаття 19 Пакту). Аналогічним чином, затримка кримінального судового розгляду на кілька років всупереч пункту 3 с) статті 14 може порушувати право особи залишати свою власну країну, гарантоване пунктом 2 статті 12 Пакту, якщо обвинуваченому доводиться залишатися в цій країні весь час, поки призупинено судовий розгляд [202].

Означеному праву було приділено суттєву увагу у практиці міжнародних контрольних органів, які функціонують у межах Організації Об’єднаних Націй.

Так, зокрема, у справі, що розглядалася Комітетом 3 прав людини (повідомлення № 845/1999) автором повідомлення був пан Ролі Кеннеді, громадянин Тринідаду i Тобаго, який очікував приведення у виконання смертного вироку в державній в'язниці Порт-оф-Спейн. Він вважав себе жертвою порушення Тринідадом і Тобаго пункту 3 статті 2; пунктів 1, 2 і 4 статті 6, статті 7; пунктів 2 і 3 статті 9; пункту 1 статті 10; пунктів 1, 3 с) і 5 статті 14; і статті 26 Міжнародного пакту про громадянські i політичні права. В обгрунтування свого повідомлення, автор зазначив, що вважає себе жертвою порушення пунктів 2 і 3 статті 9, оскільки він був поінформований про пред'явлені йому звинувачення тільки через п'ять діб після арешту і був доставлений до магістрату через шість діб після арешту; пунктів 3 с) і 5 статті 
14 на підставі невиправданих затримок судового розгляду у його справі; статей 6, 7 і пункту 1 статті 14 через обов'язковість смертного вироку за тяжке вбивство в Тринідаді і Тобаго (адвокат стверджував, що відмінність між вбивством, що карається або не карається смертною карою, яка існує в багатьох інших країнах загального права, ніколи не застосовувалося в Тринідаді і Тобаго); пунктів 2 і 4 статті 6 на тій підставі, що держава-учасниця не надала можливість для справедливого розгляду клопотання про помилування; статті 7 та пункту 1 статті 10, оскільки після арешту 4 лютого 1987 року перед пред’явленням обвинувачень і доставкою до магістрату поліцейські катували і били автора; пункту 3 статті 2 і статті 14 на тій підставі, що через відсутність юридичної допомоги автор де-факто позбавлений права клопотати перед Високим судом про захист від порушення його основоположних прав.

Держава-учасниця у поданні від 8 квітня 1999 року посилалася на документ про своє приєднання до Факультативного протоколу від 26 травня 1998 року, який містив таке застереження: «... Тринідад і Тобаго знову приєднується до Факультативного протоколу до Міжнародного пакту про громадянські i політичні права із Застереженням до його статті 1, відповідно до якої Комітет 3 прав людини не буде компетентний отримувати і розглядати повідомлення, що стосуються будь-якого ув'язненого, якому призначено смертний вирок, щодо будь-якого питання, що стосується його судового переслідування, затримання, суду над ним, його засудження, вироку або приведення у виконання винесеного йому смертного вироку, і будь-якого пов'язаного з цим питання».

Приймаючи рішення у цій справі, Комітет з прав людини зазначив, що застереження, яке було внесене після оприлюднення Зауваження загального порядку № 24 (в якому Комітет висловив думку про те, що застереження, націлене на виключення компетенції Комітету на підставі Факультативного протоколу щодо деяких положень Пакту, не може вважатися таким, що задовольняє цей критерій) не ставить за мету виключити компетенцію Комітету на підставі Факультативного протоколу щодо будь-якого конкретного положення Пакту, маючи на меті виключити таку компетенцію щодо всього 
Пакту для однієї конкретної групи заявників, а саме ув'язнених-смертників. Однак це не робить його сумісним з об'єктом і метою Факультативного протоколу. Навпаки, Комітет не може прийняти застереження, яке передбачає для будь-якої окремої групи осіб менший обсяг процесуальної захисту в порівнянні з тим, який забезпечується для всього населення. На думку Комітету, це положення має дискримінаційний характер, йдучи врозріз 3 деякими 3 основних принципів, проголошених у Пакті і протоколах до нього, і $з$ цієї причини застереження не може вважатися сумісним 3 об'єктом і метою Факультативного протоколу. Отже, ніщо не заважає Комітету розглянути повідомлення за Факультативним протоколом [204].

У справі № 925/2000 (Кой проти Португалії) Комітет 3 прав людини розглянув повідомлення, автор якого, громадянин Португалії, проживав у Макао i на той момент відбував ув'язнення в тюрмі Колоане в Макао. На момент подання повідомлення Макао було територією, що знаходилася під суверенітетом Китаю і управлінням Португалії (стаття 292 Конституції Португалії). Автор стверджував, що він $є$ жертвою порушення статті 14 Міжнародного пакту про громадянські і політичні права. Адвокат заявляв про наявність численних порушень статті 14, що стосуються передбачуваної відмови в праві на справедливий розгляд справи компетентним і неупередженим судом, порушення права вважатися невинуватим i передбачуваного порушення засадничих гарантій захисту, включаючи доступ адвоката до обвинуваченого i належне представництво обвинуваченого в ході судового розгляду.

У своєму поданні від 29 червня 2000 року держава-учасниця посилалася на статтю 2 Статуту Макао, згідно 3 якою Макао мало повну автономію i знаходилося під суверенітетом Португалії. Вона стверджувала, що, хоча дію Пакту було поширено на територію Макао парламентом Португалії відповідно до рішення 41/92 від 17 грудня 1992 року, подібного рішення щодо Факультативного протоколу прийнято не було. Держава-учасниця також вказала, що Факультативний протокол не фігурує серед договорів, зазначених у ноті, направленій урядом Португалії в листопаді 1999 року Генеральному 
SCIENTIFIC APPROACHES IN JURISPRUDENCE

секретарю Організації Об’єднаних Націй, що стосувалася тих договорів, відповідно до яких Китайська Народна Республіка погодилася взяти на себе зобов’язання в порядку правонаступництва. Держава-учасниця також вказала, що Макао не є державою-учасницею даного Протоколу, а тому просить Комітет оголосити дане повідомлення неприйнятним. Крім цього держава-учасниця просила оголосити дану справу неприйнятною оскільки в силу того, що Португалія не несе більше будь-якої відповідальності щодо Макао, будь-яка законна міжнародна процедура в даному випадку не діє.

Щодо застосовності Факультативного протоколу по відношенню до Макао в період правління Португалії до 19 грудня 1999 року, Комітет з прав людини зазначив, що держава-учасниця, приєдналася до Факультативного протоколу 3 серпня 1983 року. Крім цього, він також зазначив, що застосування Протоколу не може грунтуватися на статті 10 Факультативного протоколу, оскільки Макао після прийняття нової конституції в 1976 року не було невід’ємною частиною Португалії. Позитивний висновок також не може бути зроблено на підставі рішення 41/92 парламенту Португалії, який формально поширив дію Пакту на Макао, оскільки Пакт і Факультативний протокол є двома різними договорами. 3 іншого боку, Комітет не розділив думку про те, що факт відсутності аналогічної заяви щодо Факультативного протоколу перешкоджає застосуванню Протоколу в даному випадку. Комітет послався на формулювання статті 1 Факультативного протоколу, у вступній частині якої зазначено, що: «Держава-учасниця Пакту, яка стає учасницею цього Протоколу, визнає компетенцію Комітету приймати i розглядати повідомлення від осіб, які знаходяться під iï юрисдикції, які стверджують, що вони є жертвами порушення даною державою-учасницею будь-якого 3 прав, викладених у Пакті». Всі ці елементи у справі, що розглядається були наявні для присутніх. Португалія була учасницею як Пакту, так і Факультативного протоколу i як така визнала компетенцію Комітету отримувати i розглядати повідомлення від осіб, «які перебувають під і1і юрисдикцією». Фізичні особи в Макао підпадали під юрисдикцію Португалї̈ до 19 грудня 1999 року. В даному випадку Держава здійснювала свою юрисдикцію 
SCIENTIFIC APPROACHES IN JURISPRUDENCE

щодо автора за допомогою судів. Оскільки ідея Факультативного протоколу полягає в подальшому здійсненні закріплених у Пакті прав, незастосування Протоколу в будь-якій області, що знаходиться під юрисдикцією державиучасниці, можливе лише за наявності конкретної вказівки (Застереження / заяви), зробленої у зв’язку з цим, проте, будь-який акт такого характеру був відсутній. Тому Комітет дійшов висновку про те, що він наділений компетенцію отримувати та розглядати повідомлення (в подальшому повідомлення було визнано неприйнятним відповідно до статті 2 i пункту 2 b) статті 5 Факультативного протоколу) [204].

Варто вказати, що різні елементи права на справедливий судовий розгляд також відображені тією чи іншою мірою в регіональних актах з прав людини (Конвенція про захист прав людини і основоположних свобод 1950 р. (ст. 6), Африканська хартія прав людини і народів 1981 р. (ст. 7), Американська конвенція з прав людини 1969 р. (ст. 8), Декларація АСЕАН про права людини 2012 р. (ст. 20 (1)), Азіатська хартія прав людини 1998 р. (ст. 3.7)), Арабська хартія прав людини 2004 р. (ст. 13) та ін.). Крім цього, регіональні суди, засновані в межах міжнародних міжурядових організацій активно інтерпретують ці положення і розширюють відповідну судову практику, особливо з урахуванням того, що право на справедливий судовий розгляд і належний процес можуть мати прямі або непрямі наслідки для захисту інших прав людини.

Так, важливим прикладом захисту цього права, є справа «Олександр Волков проти України 2013 р.», що розглядалася Свропейським судом з прав людини. За обставинами справи, у 1983 році заявника було призначено посаду судді місцевого суду. На той час законодавство не передбачало вимоги щодо складання суддею присяги при призначенні на посаду. У 2003 році заявника було призначено на посаду судді Верховного Суду України (далі - ВСУ), а 30 березня 2007 року - обрано Головою Військової палати ВСУ. У грудні того ж року 3’їзд суддів України призначив заявника членом Вищої ради юстиції України (далі ВРЮ), проте заявник фактично не обійняв цієї посади у зв’язку 3 незабезпеченням паном С.К., Головою Комітету Верховної Ради України 3 
SCIENTIFIC APPROACHES IN JURISPRUDENCE

питань правосуддя (далі - парламентський комітет), можливості складання ним присяги.

У грудні 2008 року пан С.К. та двоє членів парламентського комітету звернулись до ВРЮ з клопотанням провести перевірку можливого порушення заявником його повноважень. 16 грудня 2008 року член ВРЮ пан Р.К. вніс до ВРЮ пропозицію про звільнення заявника з посади судді у зв’язку з порушенням присяги. Деякі з подій, про які йшлося у цьому клопотанні, мали місце у 2003 році. У березні 2009 року член ВРЮ пан В.К, після проведення перевірки, вніс до ВРЮ ще одну пропозицію про звільнення заявника з посади судді у зв’язку 3 порушенням присяги. Деякі з подій, про які йшлося у цьому клопотанні, мали місце у 2006 році. Про ці клопотання було повідомлено заявника.

26 травня 2010 року ВРЮ розглянула зазначені вище клопотання та вирішила рекомендувати Верховній Раді України (далі - ВРУ) звільнити заявника 3 посади судді. Заявник не був присутнім у цьому засіданні, стверджуючи, що отримав повідомлення про його проведення лише 28 травня 2010 року. 16 червня 2010 року парламентський комітет під головуванням пана С.К. розглянув відповідні подання ВРЮ та прийняв рішення рекомендувати звільнити заявника з посади судді.

17 червня 2010 року ВРУ розглянула рекомендації парламентського комітету на пленарному засіданні та ухвалила звільнити заявника. Заявник був присутнім у цьому засіданні. Заявник стверджував, що під час голосування не всі народні депутати були присутніми у залі засідань і голосування відбувалось із порушенням встановленої процедури, зокрема щодо вимоги особистого голосування.

Заявник оскаржив прийняте рішення до Вищого адміністративного суду України (далі - ВАСУ). 19 жовтня 2010 року спеціально створена Головою ВАСУ палата частково задовольнила позов заявника. Суд визнав рішення ВРЮ, прийняте за наслідками розгляду результатів перевірки, проведеної паном Р.К., незаконним, проте не скасував його через відсутність відповідних повноважень. Клопотання пана В.К. та подальші пов'язані з ним процедури, так само як i 
SCIENTIFIC APPROACHES IN JURISPRUDENCE

процедура розгляду подання ВРЮ парламентським комітетом, були визнані законними. Щодо незаконності прийнятого ВРУ рішення у зв’язку з порушенням процедури голосування суд зазначив, що він не має повноважень переглядати конституційність постанов ВРУ та що це є компетенцією Конституційного суду України.

Як стверджував заявник, на час розгляду справи строк повноважень Голови ВАСУ сплив, чинне на той час законодавство не передбачало процедури обрання суддів на адміністративні посади, а здійснення ним повноважень відбувалось на підставі рішень Президії ВАСУ та Зборів суддів адміністративних судів України. Відповідно, створена Головою ВАСУ палата не була повноважною розглядати його справу.

3 огляду на вказане, заявник скаржився за такими статтями Конвенції про захист прав людини і основоположних свобод:

- п.1 ст.6, що справа не була розглянута незалежним і безстороннім судом, встановленим законом; що провадження у ВРЮ було несправедливим, процедуру голосування у ВРУ було порушено; що заявнику не було забезпечено право на суд у зв’язку з відсутністю у ВАСУ повноважень переглядати рішення ВРЮ, а також що мало місце порушення принципу рівності сторін;

- ст. 8, що звільнення заявника 3 посади судді становило втручання у його право на повагу до приватного та професійного життя;

- ст. 13, що заявник не мав ефективних засобів юридичного захисту щодо його незаконного звільнення. Заявник також подав інші скарги.

Європейський суд встановив порушення п. 1 ст. 6 Конвенції у зв’язку 3 відсутністю незалежності та безсторонності ВРЮ з огляду на об'єктивні (процедура формування та персональний склад ВРЮ) та суб’єктивні (особиста упередженість членів ВРЮ) критерії.

Європейський суд також встановив порушення п. 1 ст. 6 Конвенції у зв’язку 3 відсутністю незалежності та безсторонності розгляду справи заявника парламентом України з огляду на те, що: розгляд справи про звільнення судді законодавчим органом слугував надмірній політизації процесу та свідчив про 
SCIENTIFIC APPROACHES IN JURISPRUDENCE

його невідповідність принципу поділу влади; він головним чином зводився до висловлення загальних думок на підставі попередніх висновків ВРЮ та парламентського комітету та ухвалення обов'язкового рішення народними депутатами, які не обов'язково є фахівцями у галузі права, здатними вирішувати складі питання фактів і права; деякі членів парламентського комітету, зокрема пан С.К., були одночасно членами ВРЮ та брали участь в ініціюванні, а потім у розгляді справи заявника в обох цих органах, та не мали законодавчо забезпеченої можливості самовідводу, а отже не могли вважатись безсторонніми.

У контексті порушення п.1 ст. 6 Конвенції Європейський суд також зазначив, що перегляд ВАСУ рішення про звільнення заявника не був достатнім та не забезпечив виправлення допущених порушень, оскільки ВАСУ: не мав повноважень скасувати рішення щодо звільнення, а лише міг визнати їх незаконними, що створює невизначеність щодо юридичних наслідків такого визнання; не розглянув з належною ретельністю важливі аргументи заявника, зокрема щодо відсутності безсторонності членів ВРЮ та парламентського комітету; не оцінив доводів заявника щодо незаконності процедури голосування у ВРУ, розтлумачивши їх які такі, що мають бути розглянуті Конституційним судом України.

Крім того, Європейський суд зазначив, що оскільки судді ВАСУ також підпадали під дисциплінарну юрисдикцію ВРЮ, вони не були незалежними та безсторонніми, розглядаючи справу, стороною якої була ВРЮ, що також становить порушення п. 1 ст. 6 Конвенції.

Європейський суд також визнав, що ані створення палати ВАСУ, яка розглядала справу заявника, ані визначення іiі складу не були легітимними, оскільки здійснювались Головою ВАСУ, строк повноважень якого сплив, а отже, це не був «суд, встановлений законом» у розумінні п.1 ст. 6 Конвенції.

Розглянувши справу, Свропейський суд одноголосно, постановив, що було порушення пункту 1 статті 6; було порушення статті 8 Конвенції; відсутня потреба розглядати скаргу за статтею 13 Конвенції. Суд також постауовив, що 
Україна має забезпечити якнайшвидше поновлення заявника на посаді судді Верховного Суду України [205].

Іншим прикладом $є$ справа «Бурмич та інші проти України», в якій Велика палата Європейського суду з прав людини прийняла рішення, яке стосується системної проблеми невиконання державою судових рішень. Європейський суд постановив вилучити із реєстру справи п'яти заявників, які скаржилися на невиконання чи надмірно тривале виконання рішень національних судів та відсутність ефективних засобів правового захисту, а разом з ними усі інші заяви, які стосуються таких самих порушень, загальна кількість яких складає 12 143. Це означає, що Свропейський суд не буде розглядати по суті однотипні індивідуальні скарги, а передасть їх на розгляд Комітету Міністрів Ради Європи. Більше того, Суд постановив, що у подальшому усі заяви проти України щодо невиконання судових рішень не будуть розглядатися, а переадресовуватимуться Комітету Міністрів [203]. 


\section{SECTION 13. THE CIVIL PROCESS}

\subsection{Problemal aspects of executive reform conduct of 2016 year}

The stage of executive proceedings is one of the most important guarantees of legality and is designed to ensure the timely and quality implementation of court decisions. The significance of enforcement proceedings is that it is the final stage of court proceedings.Its purpose is to ensure the implementation of the law, which protects the rights of individuals and legal entities, property, environment, morality, guarantees public safety and determines the exercise of state power.

Recent violent changes in special legislation testify to the global nationwide processes of reforming public administration, for the State Executive Service reform in 2016, which introduced a mixed system of enforcement, created a new legal framework for their functioning and directed to adaptation to competition in enforcement.

Changes in the legislative provision were due to the long-term inefficiency of the State Executive Service in Ukraine (hereinafter - SES). Statistics have shown the implementation of executive documents only in the range of $50 \%$ to $65 \%$ for the last five years and the amounts to be recovered - from $18 \%$ to $40 \%$. In 2016, this trend continued. Thus, out of $4,967,425$ documents that were being executed by the Internal Affairs Ministry, 848,714 were executed for the total amount of UAH 684,958,627,661 for the total amount of UAH $271,918,169,296$, which was $18.1 \%$ of the total number of executive documents and 39,69\% of the planned amounts. Such performance indicators are far behind those of Western Europe. The situation with the low level of implementation of decisions has led to the formation of a negative image of state executors among the population of Ukraine. Thus, $43.6 \%$ of respondents said they do not trust state executive representative. The current state of working conditions in the system of internal affairs bodies in Ukraine, the level of material security and social protection of state executive representative also does not contribute to the popularity of this service. $57 \%$ of surveyed state executive representative expressed 
dissatisfaction with their work, and said that they do not consider their profession prestigious.

Issues of implementation of enforcement decisions and the legal status of State Executive Service in Ukraine at different historical stages have attracted the attention of representatives of various branches of legal science. Thus, the features of enforcement proceedings were studied by: Ch. N. Azimov, VA Babych, DM Bakhrakh, B. Ya. Bachuk, SS Bychkova, Yu. V. Bilousov, OP Botezat, D H. Valeev, AS Vasiliev, Yu. G. Vdovina, M. Yu. Vikhlyaev, MV Golub, EM Grishko, OS Gusarova, MA Danilyan, VI Evintov, IV Zozulya, RA Kalyuzhny, OM Kaplya, TO Kolomoyets, VK Kolpakov, AT Komzyuk, SP Korneychuk, VA Kroytor , S. Yu. Lobantsev, PS Lyutikov, EI Mezentsev, RV Myronyuk, VP Nagrebelny, OV Negodchenko, SV Olefirenko, IV Reshetnikova, L S. Samsonova, VA Seleznyov, DM Sibilov, SG Stetsenko, VV Sukhonos, VI Tertishnikov, TD Filatova, MM Frolov, S. Ya. Fursa, VD, Chernadchuk, KV Shkarupa, TO Shklyar, J. Stefan, MM Shchupenya, LI Yakimov, VV Yarkov [212].

Inadequate executive procedure often nullifies the court's work in considering and resolving a particular case.

Improving executive procedure involves, on the one hand, solving problems of adaptation to the requirements of the European Union of organizational structures of the State Executive Service, and on the other hand it consolidates and solving problems related to the protection of human rights and interests of the state.

Studies of this issue are contained in the works of domestic and foreign scientists, in particular VV Barankova, Yu.V. Bilousova, PP Zavorotko, VV Komarova, VI Tertishnikova, VM Sherstyuka, M.Y. Stefan, S.W. Щербака, М.K. Yukov et al., who expressed their own views on solving the problems of executive proceedings.

In the event of a violation of any constitutional rights or interests, a person or legal entity apply to a court or other State Body, hoping that the state which they hold at their own expense will protect them from wrongdoing and help restore the violated rights and legitimate interests. 
Article 19 of the Constitution of Ukraine states that public authorities and local governments, their officials are obliged to act only on the basis, within the powers and in the manner prescribed by the Constitution and laws of Ukraine [206].

In accordance with the provisions of Article 124 of the Constitution of Ukraine and Article 13 of the Law of Ukraine «On the Judiciary and the Status of Judges», the court decision is enforceable both in person and in space (is mandatory for all public authorities, local governments, their officials, associations of citizens and other organizations, citizens and legal entities throughout Ukraine) [207].

Article 1 of the Law of Ukraine «On Executive Procedure» establishes a range of regulations that constitute the legal basis for the activities of the State Executive Service. Based on the legal force of legal norms in the hierarchy of normative legal acts, the Constitution of Ukraine occupies a key place, which establishes the general principles of functioning of public authorities and their relations with citizens and other persons and serves as a basis for other laws. (state executive representative) and in cases provided by this Law for private executor representatsve, the legal status and organization of which are established by the Law of Ukraine «On bodies and persons carrying out enforcement of court decisions and decisions of other bodies" [208].

Undoubtedly, the most optimal result is the voluntary execution of acts of courts and other bodies, and in case of refusal to execute these acts voluntarily, an effective mechanism is needed to ensure their enforcement. Despite the fact that modern society is very interested in the correct and timely implementation of such acts, the procedural mechanism of their enforcement does not fully correspond to today's realities.

Enforcement proceedings are still considered a weak link in the mechanism for protecting the rights of citizens and legal entities and need significant restructuring. Improper and untimely execution of decisions of courts and other bodies continues to be one of the reasons for the decline of the authority of the judiciary.

The reasons for this provision can be reduced to the inefficiency of legal, organizational and economic mechanisms for the organization of enforcement proceedings and in general the legal infrastructure of Ukraine. Various measures are 
possible to increase enforcement, for example, related to increasing the powers of executors, which are taken by the Ministry of Justice of Ukraine.

The set of accumulated scientific concepts, practical recommendations and proposals for regulations governing enforcement proceedings led to the reform of the legal framework governing enforcement proceedings in 2016, which became the starting point for the formation of a mixed system of enforcement in Ukraine.

These changes are aimed at ensuring an effective mechanism for rapid and complete implementation of decisions, including through the unloading of the State Executive Service (hereinafter - ICE).

Radical reform of the system of enforcement of decisions in Ukraine consists of the following main changes: the institute of private executors who carry out their professional activities at the level of the Internal Affairs Department and in compliance with the Law of Ukraine "On State Enforcement Service"; the Unified Register of Debtors and the Unified Register of Private Executors were introduced; at the opening of enforcement proceedings, the term for independent (voluntary) execution of the decision is not given to the debtor; the executor at the opening of enforcement proceedings is obliged to immediately seize the property (funds) of the debtor; after the opening of enforcement proceedings, the executor obliges the debtor to submit a declaration of income and property; determination of the value of the debtor's property should be carried out by mutual consent of the debt collector and the debtor, if such an agreement is not reached, the subject of valuation activity - the business entity is involved in the valuation of the property; the sale of the debtor's property is carried out at electronic auctions; the terms of committing significant executive actions have been changed; the Law on Enforcement Proceedings excludes provisions on control over the legality of enforcement proceedings by the governing bodies of the Internal Affairs Ministry; The Law of Ukraine "On Bodies and Persons Enforcing Judgments and Decisions of Other Bodies", in contrast to the repealed Law of Ukraine "On the State Enforcement Service", does not contain a number of norms that determine the structure of the state executive service, competence of internal affairs bodies to organize its activities, requirements for heads of structural internal affairs bodies. 
The problem is that enforcement proceedings is opened by a public or private executor who is not subordinate to the court or other bodies (officials), and the current legislation does not provide for interaction between these bodies during the joint execution of court decisions of other bodies.

An important factor is also the high workload per executive representative in the performance of their professional duties, as well as insufficient training.

Recently, the latest technologies is very quickly used by the Ministry of Justice of Ukraine, the changing of paperwork into electronic form, but the executive service of these technologies are actually bypassed. There is no such thing as e-mail correspondence with stakeholders in the work of the executive service.

All that the citizen sees while communicating with state executors these are the iron doors, which are still closed, and the reception schedule twice a week for only a few hours.

Last but not least, all these problems are caused by the low quality of education of employees of the executive service, and insufficient motivation. In particular, in the work of the executive service such a phenomenon as holding seminars with the participation of scientists and leading lawyers is quite rare. The concept of in-service training is severely lame.

One of the reasons that the institution of enforcement proceedings is in decline can be identified, in particular, the lack of attention of scholars and practitioners to the problems of enforcement of court decisions in the period of economic relations, and this situation causes uncertainty in the legal science system, use in enforcement proceedings process. Most scholars and legal practitioners see an improvement in the number of implemented court decisions in the established institution of private bailiffs. Taking into account the experience of foreign countries, the introduction of the institution of private executors leads to more effective results than when only state executors are engaged in the execution of court decisions.

However, this process requires very careful work on its regulation, because in fact the interest of the private executor in the execution of decisions is based primarily 
on financial income, which is calculated in the amount of the principal fee levied on the debtor subject to full or partial execution of the decision .

In connection with Ukraine's accession to the Council of Europe (under the jurisdiction of the European Court of Human Rights since November 9, 1995), it has additional responsibilities to protect human and civil rights and freedoms and harmonize Ukrainian legislation in the field of enforcement proceedings with the rules of international law. In this regard, I believe that there is a need to create an independent branch - civil executive law.

Problems of human rights protection in enforcement proceedings are experiencing a new wave of urgency in connection with the restructuring of structural elements of society in the direction of improving the legal field of the state, which has grown from departmental to national and even international, as Ukrainian citizens have the right to appeal to the European Court of Human Rights due to innovations in the law enforcement process.

The right of a citizen of Ukraine to enforce a court decision that has entered into force is enshrined in domestic law and international law, in particular Art. 6 of the Convention for the Protection of Human Rights and Fundamental Freedoms "right to a court", establishes the right of a person to a fair and public hearing within a reasonable time by an independent and impartial tribunal established by law, in determining the civil rights and obligations of a person case, and hence the restoration of justice, involves the obligation of administrative bodies to comply with court decisions.

Recommendations of the Committee of Ministers of the Council of Europe date on 9 September 2003 № Ree (2003) 17 «On Enforcement» stipulate that enforcement of a court decision must reasonably balance the interests of both the debt collector and the debtor, and in some cases also take into account interests of third parties, currently it is important to optimize the practical activities of the internal affairs bodies and other participants in enforcement proceedings, because it is necessary to find and maintain a balance of interests in the first place the collector and the debtor. This task can be successfully implemented only through a balanced, stable and universal system of procedural guarantees. 
. On April 21, 1999, the Verkhovna Rada of Ukraine adopted the Law of Ukraine «On Enforcement Proceedings», which defined the conditions and procedure for enforcement of decisions of courts and other bodies (officials) that are subject to enforcement in case of non-enforcement [208].

The adoption by the Verkhovna Rada of Ukraine on 23 June 2005 of the Law of Ukraine «On Amendments to the Laws of Ukraine» On Civil Enforcement Service «and» On Enforcement Proceedings» was recognized by the Parliamentary Assembly of the Council of Europe, paragraph 6.9 of Resolution 1466 (2005) as one of the significant achievements of progress in Ukraine, which strengthens the activities of the civil service for the execution of court decisions in non-criminal cases [210].

The next attempt to bring enforcement of court decisions closer to the standards of the European Union were the Law of Ukraine «On Enforcement Proceedings» of June 2, 2016, the Law of Ukraine «On Bodies and Persons Enforcing Judgments and Decisions of Other Bodies» of June 2, 2016, Law of Ukraine «On State Guarantees for Execution of Judgments» of June 5, 2012, Law of Ukraine «On Imposition of a Moratorium on Compulsory Sale of Property» of November 29, 2001, Law of Ukraine «On Moratorium on Recovery of Property of Ukrainian Citizens currency» of June 3, 2014, the Law of Ukraine «On Mortgage» of June 5, 2003, other laws and regulations, in particular, the Instruction on the organization of enforcement of decisions, approved by the Order of the Ministry of Justice of Ukraine of April 2, 2012 № 512 / 5 and registered with the Ministry of Justice of Ukraine on April 2, 2012 under № 489/20802, accepted for their implementation.

At the same time, the legal basis for the activities of the state executive service is normative acts, namely the Civil Code of Ukraine, the Civil Procedure Code of Ukraine, the Commercial Code of Ukraine, the Commercial Procedural Code of Ukraine, the Family Code of Ukraine, Decisions (conclusions) of the Constitutional Court of Ukraine.

The process of enforcing a court decision is a problematic issue in Ukraine. The decision of the European Court of Human Rights in the case of «Ivanov v. Ukraine», 
which became a pilot and stated the systemic problem of non-compliance with the decisions of national courts, confirmed the existence of this problem.

The European Court of Human Rights then took more drastic action and ruled in «Burmych v. Ukraine», combining some 12,000 applications into one case and submitting them to the Committee of Ministers of the Council of Europe.

Therefore, the reform in the field of enforcement proceedings is important for our state, as it aims to protect human rights and is designed to address the implementation of the right to a fair trial, peaceful possession of property, the right to effective protection. In the process of reform, many innovations were made regarding the terms, grounds for certain actions in enforcement proceedings, the introduction of the institution of private performers and new electronic registers. 


\section{SECTION 14. THE CRIMINAL PROCESS}

\subsection{Features of criminal proceedings to barristers}

Всі громадяни мають рівні конституційні права і свободи та є рівними перед законом. Відповідно до ч. 1, 2 ст. 24 Конституції України не може бути привілеїв чи обмежень за ознаками раси, кольору шкіри, політичних, релігійних та інших переконань, статі, етнічного походження, майнового стану, місця проживання, за мовними або іншими ознаками. Проте, кримінальний процесуальний закон встановлює особливості провадження щодо окремої категорії осіб (глава 37 КПК України).

Особливий порядок кримінального провадження здійснюється стосовно осіб, зазначених у ст. 480 КПК України (далі КПК), зокрема, професійного адвоката. Окрім КПК, особливості притягнення до кримінальної відповідальності адвокатів визначаються Конституцією України, законом України «Про адвокатуру та адвокатську діяльність» від 05.07.2012р., та відповідними підзаконними актами: Правилами адвокатської етики, затвердженими Звітно-виборним з'їздом адвокатів України 09.06.2017р., зі змінами затвердженими 3’їздом адвокатів України 15.02.2019р. та ін.

Визначальними рисами особливого порядку кримінального провадження є: особливі порядки повідомлення про підозру, затримання, обрання запобіжного заходу у вигляді тримання під вартою чи домашнього арешту, допиту, обшуку, огляду житла, іншого володіння адвоката, приміщень, де він здійснює адвокатську діяльність, тимчасового доступу до речей і документів адвоката, відсторонення адвоката від справи.

\section{1. Конституційно-правовий статус адвоката}

Конституційно-правовий статус адвоката законодавець розкриває в Конституції України, Законі України «Про адвокатуру та адвокатську діяльність» та деяких інших правових актах. Ст. 131-2 Конституції України проголошує незалежність адвокатури. Ст. 6 Закону України «Про адвокатуру та 
адвокатську діяльність» встановлює загальні вимоги для адвокатів: адвокатом може бути фізична особа, яка має повну вищу юридичну освіту, володіє державною мовою, має стаж роботи в галузі права не менше 2 років, склала кваліфікаційний іспит, пройшла стажування (крім випадків, встановлених цим Законом), склала присягу адвоката України та отримала свідоцтво про право на заняття адвокатською діяльністю; не може бути адвокатом особа, яка: 1) має непогашену чи незняту в установленому законом порядку судимість за вчинення тяжкого, особливо тяжкого злочину, а також злочину середньої тяжкості, за який призначено покарання у виді позбавлення волі; 2) визнана судом недієздатною чи обмежено дієздатною; 3) позбавлена права на заняття адвокатською діяльністю, - протягом двох років з дня прийняття рішення про припинення права на заняття адвокатською діяльністю; 4) звільнена 3 посади судді, прокурора, слідчого, нотаріуса, з державної служби або служби в органах місцевого самоврядування за порушення присяги, вчинення корупційного правопорушення, - протягом трьох років з дня такого звільнення. Ст. 7 Закону України «Про адвокатуру та адвокатську діяльність» визначає, що діяльністю, несумісною з діяльністю адвоката, є: 1) робота на посадах осіб, зазначених у пункті 1 частини першої статті 3 Закону України "Про запобігання корупції", 2) військова або альтернативна (невійськова) служба; 3) нотаріальна діяльність; 4) судово-експертна діяльність. Вимоги щодо несумісності з діяльністю адвоката, передбачені п. 1 ч. 1 ст. 7 Законом України «Про адвокатуру та адвокатську діяльність», не поширюються на депутатів Верховної Ради Автономної Республіки Крим, депутатів місцевих рад (крім тих, які здійснюють свої повноваження у відповідній раді на постійній основі).

Відповідно до ст. ст. 20, 21 Закону України «Про адвокатуру та адвокатську діяльність» адвокат має наступні права та обов'язки - права: 1) звертатися 3 адвокатськими запитами, 2) представляти і захищати права, свободи та інтереси фізичних осіб, права та інтереси юридичних осіб у суді, органах державної влади та органах місцевого самоврядування, на підприємствах, в установах, організаціях незалежно від форми власності, громадських об’єднаннях, перед 
SCIENTIFIC APPROACHES IN JURISPRUDENCE

громадянами, посадовими i службовими особами, до повноважень яких належить вирішення відповідних питань в Україні та за іiі межами, 3) ознайомлюватися на підприємствах, в установах і організаціях з необхідними для адвокатської діяльності документами та матеріалами, крім тих, що містять інформацію з обмеженим доступом, 4) складати правові документи та подавати їх у встановленому законом порядку, 5) доповідати клопотання та скарги на прийомі в посадових і службових осіб та відповідно до закону одержувати від них письмові мотивовані відповіді на ці клопотання і скарги, 6) бути присутнім під час розгляду своїх клопотань і скарг на засіданнях колегіальних органів та давати пояснення щодо суті клопотань і скарг, 7) збирати відомості про факти, що можуть бути використані як докази, в установленому законом порядку запитувати, отримувати і вилучати речі, документи, їх копії, ознайомлюватися 3 ними та опитувати осіб за їх згодою, 8) застосовувати технічні засоби, фіксувати процесуальні дії, в яких він бере участь, а також хід судового засідання в порядку, передбаченому законом, 9) посвідчувати копії документів у справах, які він веде, крім випадків, якщо законом установлено інший обов'язковий спосіб посвідчення копій документів, 10) одержувати письмові висновки фахівців, експертів 3 питань, що потребують спеціальних знань; обов'язки: 1) дотримуватися присяги адвоката України та правил адвокатської етики, 2) на вимогу клієнта надати звіт про виконання договору про надання правової допомоги, 3) невідкладно повідомляти клієнта про виникнення конфлікту інтересів, 4) підвищувати свій професійний рівень, 5) виконувати рішення органів адвокатського самоврядування.

\section{2. Індемнітет адвокату від кримінального переслідування}

Інститут індемнітету адвоката - один із ключових статусних елементів організації адвокатури. Він забезпечує самостійність і незалежність адвокатів. Його стислу сутність Заборовський В. В. визначає як неможливість притягнути адвоката до кримінальної відповідальності у зв’язку зі здійсненням ним його професійної діяльності. Ст. 23 Закону України «Про адвокатуру та адвокатську 
SCIENTIFIC APPROACHES IN JURISPRUDENCE

діяльність» передбачає наступні гарантії індемнітету адвоката: орган або посадові особи, які затримали адвоката або застосували до нього запобіжний захід, зобов'язані негайно повідомити про це відповідну раду адвокатів регіону; повідомлення про підозру адвоката у вчиненні кримінального правопорушення може бути здійснене виключно Генеральним прокурором, його заступником, прокурором АРК, області, міст Києва та Севастополя; забороняється притягати до кримінальної чи іншої відповідальності адвоката (особу, стосовно якої припинено або зупинено право на заняття адвокатською діяльністю) або погрожувати застосуванням відповідальності у зв'язку із здійсненням ним адвокатської діяльності згідно із законом чи за його висловлювання у справі, якщо при цьому не порушуються професійні обов'язки адвоката; забороняються проведення огляду, розголошення, витребування чи вилучення документів, пов'язаних із здійсненням адвокатської діяльності, допиту адвоката чи його співробітників з питань, які становлять адвокатську таємницю, залучення адвоката до конфіденційного співробітництва під час проведення оперативнорозшукових заходів чи слідчих дій, якщо таке співробітництво буде пов'язане або може призвести до розкриття адвокатської таємниці. Також до гарантій індемнітету адвоката слід віднести викладені в цієї ж статті вимоги проведення стосовно адвоката оперативно-розшукових заходів чи слідчих дій, що можуть проводитися виключно з дозволу суду, на підставі судового рішення, ухваленого за клопотанням Генерального прокурора, його заступників, прокурора АРК, області, міст Києва та Севастополя, причому у випадку проведення обшуку чи огляду житла, іншого володіння адвоката, приміщень, де він здійснює адвокатську діяльність, тимчасового доступу до речей і документів адвоката у судовому рішенні в обов'язковому порядку повинно бути зазначено перелік речей, документів, що планується відшукати, виявити чи вилучити під час проведення слідчої дії чи застосування заходу забезпечення кримінального провадження і враховано вимоги п. п. 2-4 ч. 1 ст. 23 Закону України «Про адвокатуру та адвокатську діяльність». 


\section{3. Порядок затримання адвоката та застосування до нього запобіжних} заходів

Особливістю порядку затримання адвоката та застосування до нього запобіжних заходів є зобов'язання органу або посадової особи, які затримали адвоката або застосували до нього запобіжний захід, негайно повідомити про це відповідну раду адвокатів регіону відповідно до п.12 ч.1 ст.23 Закону України «Про адвокатуру та адвокатську діяльність». Це стосується усіх видів запобіжних заходів та усіх видів затримання, які зазначені у КПК. Кримінальні правопорушення, які вчиняються адвокатами, поділяються на 3 види: (а) ті, які адвокат вчиняє поза межами своєї професійної діяльності, (б) ті, що пов’язані з його спеціальним статусом, (в) ті, що може вчинити лише адвокат. До другого виду належать усі кримінальні правопорушення, які передбачені в Розділі XVII КK України та кримінальні правопорушення, які передбачені ст.. ст.. 376, 376-1, 381, 386, 387, 396 КК України. До третього виду належить злочин, який передбачено ст.. 400-1 КК України.

\section{4. Порядок повідомлення адвоката про підозру}

п.1 ч.1 ст.481 КПК та п.13 ч.1 ст.23 Закону України «Про адвокатуру та адвокатську діяльність» надають адвокату подвійний захист в аспекті переходу його до статусу підозрюваного - письмове повідомлення адвоката про підозру може бути здійснено лише Генеральним прокурором, його заступником, керівником регіональної прокуратури в межах його повноважень. Складення, вручення повідомлення про підозру будь-якою іншою особою робить це повідомлення нікчемним. Слід зауважити, що будь-який слідчий або прокурор може внести відомості про вчинення адвокатом кримінального правопорушення до Єдиного реєстру досудових розслідувань.

5. Порядок проведення стосовно адвоката оперативно-розшукових заходів чи слідчих дій під час досудового розслідування 
п.3 ч.1 ст.23 Закону України «Про адвокатуру та адвокатську діяльність» встановлює головну обов'язкову вимогу для проведення стосовно адвоката оперативно-розшукових заходів чи слідчих дій, що можуть проводитися виключно з дозволу суду, - підставу у вигляді судового рішення про проведення, ухваленого за клопотанням Генерального прокурора, його заступників, прокурора АРК, області, міст Києва та Севастополя.

Залежно від того, чи підлягають розголошенню відомості про факт та методи їх проведення, слідчі дії поділяються на слідчі дії (гл. 20 КПК) та негласні слідчі дії (гл. 21 КПК). Відповідно до абз.2 п.20 ч.1 ст.8 Закону України «Про оперативно-розшукову діяльність» від 18.02.1992 р. прийняття рішення про проведення оперативно-розшукових заходів, подання та розгляд відповідних клопотань, проведення оперативно-розшукових заходів, фіксація та використання їх результатів, проведення цих заходів до постановлення ухвали слідчого судді та інші питання їх проведення регулюються згідно з гл. 21 КПК, 3 чого випливає, що оперативно-розшукові заходи - це негласні слідчі дії.

Допит не належить до слідчих дій, які можуть проводитися виключно 3 дозволу суду, але п.2 ч.1 ст.23 Закону України «Про адвокатуру та адвокатську діяльність» та ч.8 ст.224 КПК прямо забороняють допит адвоката та його співробітників з питань, які становлять адвокатську таємницю. Пред’явлення для впізнання та освідування не належать до слідчих дій, які можуть проводитися виключно з дозволу суду. Обшук відповідно до ч.2 ст.234 КПК та огляд житла чи іншого володіння особи відповідно до ч.2 ст.237 КПК є слідчими діями, які проводяться виключно на підставі ухвали слідчого судді, яка згідно з ч.2 ст.23 Закону України «Про адвокатуру та адвокатську діяльність» в обов’язковому порядку зазначає перелік речей, документів, що планується відшукати, виявити чи вилучити під час проведення слідчої дії чи застосування заходу забезпечення кримінального провадження, а також враховує вимоги збереження адвокатської таємниці. Згідно з тією ж частиною під час проведення обшуку чи огляду житла, іншого володіння адвоката, приміщень, де він здійснює адвокатську діяльність, має бути присутній представник ради адвокатів регіону, який має право ставити 
запитання, подавати свої зауваження та заперечення щодо порядку проведення процесуальних дій, що зазначаються у протоколі. Службова особа, яка буде проводити обшук чи огляд, завчасно повідомляє про це раду адвокатів регіону за місцем проведення такої процесуальної дії. Проведення слідчого експерименту (ст..240 КПК) не вимагає дозволу суду на дану слідчу дію, якщо не проводиться в житлі чи іншому володінні особи, в цьому випадку процедура отримання дозволу як дозволу на обшук. Згідно з ст..ст. 243, 245 КПК слідчі дії у вигляді залучення експерта для проведення експертизи та отримання зразків для експертизи можливі як за дозволом суду, так і без нього.

Негласними слідчими діями, які проводяться виключно за ухвалою слідчого судді, є втручання у приватне спілкування, яке поділяється на: 1) аудіо-, відео контроль особи; 2) арешт, огляд і виїмка кореспонденції; 3) зняття інформації 3 транспортних телекомунікаційних мереж; 4) зняття інформації з електронних інформаційних систем. При цьому втручання у приватне спілкування захисника з підозрюваним, обвинуваченим, засудженим, виправданим заборонене (ст. 258 КПК). Обстеження шляхом таємного проникнення до публічно недоступних місць, житла чи іншого володіння особи (ч.4 ст.267 КПК), установлення місцезнаходження радіоелектронного засобу (ч.2 ст.268 КПК), спостереження за особою, річчю або місцем (ч.2 ст.269 КПК), моніторинг банківських рахунків (ч.1 ст.269-1 КПК), аудіо-відео контроль місця (ч.2 ст.270 КПК), негласне отримання зразків для порівняльного дослідження (ч.2 ст.274 КПК) належать до негласних слідчих дій, які проводяться виключно за ухвалою слідчого судді. Контроль за вчиненням злочину (ст..271 КПК) та виконання спеціального завдання $з$ розкриття злочинної діяльності організованої групи чи злочинної організації (ст.272 КПК) не належать до негласних слідчих дій, які проводяться за ухвалою слідчого судді. Конфіденційне співробітництво 3 адвокатом, яке пов'язане $з$ розкриттям конфіденційної інформації професійного характеру, заборонене (ст..275 КПК). 


\section{6. Порядок проведення тимчасового доступу до речей i документів}

\section{адвоката}

Окремим питанням постає порядок проведення тимчасового доступу до речей і документів адвоката. Ст. 22 Закону України «Про адвокатуру та адвокатську діяльність» визначає, що адвокатською таємницею є будь-яка інформація, що стала відома адвокату чи його співробітникам, про клієнта, а також питання, з яких клієнт звертався до адвоката, зміст порад, консультацій, роз'яснень адвоката, складені ним документи, документи і відомості, одержані адвокатом під час здійснення адвокатської діяльності. Особливості порядку проведення тимчасового доступу до речей і документів адвоката спрямовані на збереження адвокатської таємниці. П.4 ч.1 ст.23 Закону України «Про адвокатуру та адвокатську діяльність» забороняє проведення огляду, розголошення, витребування чи вилучення документів, пов'язаних із здійсненням адвокатської діяльності, ст.161 КПК забороняє доступ до листування або інших форм обміну інформацією між захисником та його клієнтом або будь-якою особою, яка представляє його клієнта, у зв’язку 3 наданням правової допомоги. Тимчасовий доступ до речей і документів адвоката надається за ухвалою слідчого судді (ст.164 КПК), тому відповідно до ч.2 ст.23 Закону України «Про адвокатуру та адвокатську діяльність» в ухвалі обов’язково зазначено перелік речей, документів, що планується відшукати, виявити чи вилучити під час тимчасового доступу до речей і документів адвоката, також під час проведення тимчасового доступу до речей і документів адвоката має бути присутній представник ради адвокатів регіону, так само, як при обшуку чи огляді. Службова особа, яка буде проводити тимчасовий доступ до речей i документів адвоката, завчасно повідомляє про це раду адвокатів регіону за місцем проведення такої процесуальної дії.

7. Припинення чи зупинення права на заняття адвокатською діяльністю внаслідок набрання щодо адвоката законної сили обвинувальним вироком суду 
Відповідно до п.2 ч.1 ст.31 Закону України «Про адвокатуру та адвокатську діяльність» набрання законної сили обвинувальним вироком суду стосовно адвоката за вчинення нетяжкого злочину чи злочину середньої тяжкості, за який не призначено покарання у виді позбавлення волі, викликає зупинення права на заняття адвокатською діяльністю $з$ дня набрання законної сили відповідним рішенням суду. У цьому випадку згідно з п.2 ч.4 ст.31 Закону України «Про адвокатуру та адвокатську діяльність» право на заняття адвокатською діяльністю поновлюється з дня, наступного за днем отримання радою адвокатів регіону підтвердження про погашення або зняття в установленому законом порядку судимості.

Відповідно до п.6 ч.1 ст.32 Закону України «Про адвокатуру та адвокатську діяльність» набрання законної сили обвинувальним вироком суду стосовно адвоката за вчинення за вчинення тяжкого, особливо тяжкого злочину, а також злочину середньої тяжкості, за який призначено покарання у виді позбавлення волі, викликає припинення права на заняття адвокатською діяльністю 3 дня набрання законної сили відповідним рішенням суду. Припинення права особи на заняття адвокатською діяльністю має наслідком не тільки припинення такої діяльності, а і припинення права особи на участь у роботі органів адвокатського самоврядування. 


\section{2 Застосування примусових заходів виховного характеру до неповнолітніх}

Протиправна діяльність неповнолітніх викликає підвищену увагу, так як вона являється одним із індикаторів соціальної ситуації в країні, а боротьба із нею являється однією із найважливіших завдань суспільства. Важливу роль в цьому відіграють заходи, направлені на попередження злочинності неповнолітніх, серед яких виділяють примусові заходи виховного характеру. Тобто, виховний вплив держави в першу чергу направлений на правопорушників-дітей - тих, хто в силу свого віку не міг усвідомлювати суспільно небезпечні наслідки своїх протиправних дій.

Безумовно, суспільно небезпечне діяння, що містить ознаки кримінального правопорушення, не може залишитись некараним. Проте, не кожна особа, яка його вчинила, i не за будь-яких обставин має неодмінно підлягати покаранню. Тому, у чинному законодавстві містяться норми, що стосуються застосування примусових заходів виховного характеру до неповнолітніх правопорушників як форма звільнення від кримінальної відповідальності [232,233].

У разі звільнення від кримінальної відповідальності має місце так звана юридична фікція. Держава піддає «забуттю» діяння, що містить ознаки складу кримінального правопорушення, яке вчинила неповнолітня особа. 3 огляду на це, всі кримінально-правові наслідки вчиненого діяння анулюються, воно визнається таким, що не мало місця. Таким чином, звільнення неповнолітніх від кримінальної відповідальності полягає у відмові держави від осуду неповнолітньої особи, котра вчинила суспільно небезпечне протиправне діяння, і така особа не зазнає несприятливих наслідків. Міжнародна Конвенція про права дитини орієнтує на таке поводження з неповнолітнім правопорушником, яке сприяє розвиткові в дитини почуття гідності й значущості, зміцнює в ній повагу до прав людини й основних свобод інших та при якому враховуються вік дитини і бажаність сприяння їі реінтеграції та виконання нею корисної ролі в суспільстві [235]. Але у будь якому разі, навіть після звільнення від відповідальності із застосуванням примусових заходів виховного характеру, відбувається 
SCIENTIFIC APPROACHES IN JURISPRUDENCE

«стигматизація» (з гр. stigma - ярлик, тавро, пляма) такої особи, тобто починається так зване соціальне маркування як реакція на девіантну, протиправну поведінку, що може негативно в подальшому вплинути на підлітка.

Неповнолітній, який вчинив кримінальний проступок або нетяжкий злочин, може бути звільнений судом від покарання, якщо буде визнано, що внаслідок щирого розкаяння та подальшої бездоганної поведінки він на момент постановлення вироку не потребує застосування покарання (ст. 105 КК України) [233]. У цьому разі суд застосовує до неповнолітнього такі примусові заходи виховного характеру:

1) застереження;

2) обмеження дозвілля i встановлення особливих вимог до поведінки неповнолітнього;

3) передача неповнолітнього під нагляд батьків чи осіб, які їх заміняють, чи під нагляд педагогічного або трудового колективу за його згодою, а також окремих громадян на їхнє прохання;

4) покладення на неповнолітнього, який досяг п'ятнадцятирічного віку і має майно, кошти або заробіток, обов'язку відшкодування заподіяних майнових збитків;

5) направлення неповнолітнього до спеціальної навчально-виховної установи для дітей і підлітків до його виправлення, але на строк, що не перевищує трьох років. Умови перебування в цих установах неповнолітніх та порядок їх залишення визначаються законом [233].

Розглянемо вказані примусові заходи. Застереження є одним із найм’якіших заходів виховного характеру, може бути зроблено шляхом роз'яснення судом неповнолітньому правопорушнику наслідків його дій - шкоди, завданої охоронюваним законом правам особи, інтересам суспільства або держави, та оголошення неповнолітньому правопорушнику осуду за ці дії, а також попередження про більш суворі правові наслідки, які можуть настати в разі продовження ним протиправної поведінки чи вчинення нового суспільно небезпечного діяння [236]. 
Обмеження дозвілля і встановлення особливих вимог щодо поведінки неповнолітнього правопорушника слід розуміти як обмеження перебування поза домівкою в певний час доби; заборону відвідувати певні місця; змінювати без згоди органу, який здійснює за ним нагляд, місце проживання, навчання чи роботи, виїжджати в іншу місцевість; покладення обов'язку продовжити навчання, пройти курс лікування (за наявності хворобливого потягу до спиртного або в разі вживання наркотичних засобів, психотропних речовин, їх аналогів); тощо[236].

Передача неповнолітнього під нагляд батьків або осіб, які їх заміняють, допускається лише за наявності даних про те, що вони здатні забезпечити позитивний виховний вплив на нього та постійний контроль за його поведінкою. Особами, які заміняють батьків, є, зокрема, усиновителі, опікуни i піклувальники. Питання про передачу неповнолітнього під нагляд батьків або осіб, які їх заміняють, суд повинен вирішувати з урахуванням даних, що їх характеризують. Неприпустимо передавати неповнолітнього під нагляд батька чи матері, які позбавлені батьківських прав, а також батьків чи інших осіб, котрі через свою поведінку не здатні позитивно впливати на нього. Хоча в законі не передбачено обов'язкове отримання згоди батьків або осіб, які їх заміняють, на передачу їм неповнолітнього під нагляд, суд має отримати таку згоду. Неповнолітнього правопорушника також можна передати під нагляд педагогічного (за місцем навчання) чи трудового (за місцем роботи) колективу за згодою цього колективу, а також під нагляд окремих громадян - на їхнє прохання. При цьому як педагогічний чи трудовий колектив, так i окремий громадянин мають бути спроможні здійснювати виховний вплив на неповнолітнього, постійно й належним чином контролювати його поведінку та зобов'язані це робити. Строк нагляду суд встановлює з урахуванням конкретних обставин справи та мети виправлення неповнолітнього. Як свідчить практика, цей нагляд має здійснюватись, як правило, не менше одного року, оскільки за коротшого строку він буде малоефективним (але не довше, ніж до досягнення особою повноліття) [236]. 
SCIENTIFIC APPROACHES IN JURISPRUDENCE

Покладення обов'язку відшкодувати заподіяні майнові збитки як примусовий захід виховного характеру можна застосовувати лише до неповнолітнього, який досяг 15 років, має майно чи кошти, що є його власністю, або самостійно одержує заробіток (заробітну плату, стипендію тощо). У постанові (ухвалі) суд повинен зазначити розмір збитків, що підлягають відшкодуванню, та строки виконання цього рішення [236].

До спеціальних навчально-виховних установ направляють неповнолітніх, котрі вийшли 3-під контролю батьків чи осіб, які їх заміняють, не піддаються виховному впливу та не можуть бути виправлені шляхом застосування інших примусових заходів виховного характеру. До таких установ не можна направляти осіб, визнаних інвалідами, а також тих, кому згідно з висновком відповідних спеціалістів перебування там протипоказане за станом здоров'я через наявність певних захворювань. До спеціальних навчально-виховних установ належать загальноосвітні школи соціальної реабілітації та професійні училища соціальної реабілітації. Неповнолітній правопорушник, якого направлено до загальноосвітньої школи соціальної реабілітації або професійного училища соціальної реабілітації, за своїм правовим статусом є учнем, щодо якого положеннями про ці навчально-виховні установи встановлено певні обмеження. Учнів тримають у зазначених установах у межах установленого судом строку, але не більше трьох років: у загальноосвітніх школах соціальної реабілітації - до досягнення ними 14, у професійних училищах соціальної реабілітації - 18 років, а у виняткових випадках (якщо це необхідно для завершення навчального року або професійної підготовки) за рішенням суду - відповідно 15 і 19 років [236].

Відповідно до Постанови пленуму Верховного Суду України «Про практику розгляду судами справ про застосування примусових заходів виховного характеру» № 2 від 15.05.2006 року, метою застосування вище вказаних примусових заходів має бути забезпечення інтересів неповнолітнього, які полягають в одержанні не тільки належного виховання, а й освіти, лікування, соціальної, психологічної допомоги, захисту від жорстокого поводження, насильства та експлуатації, а також у наявності можливості адаптуватися до 
SCIENTIFIC APPROACHES IN JURISPRUDENCE

реалій суспільного життя, підвищити загальноосвітній і культурний рівень, набути професії та працевлаштуватися. Тобто, примусові заходи виховного характеру $\epsilon$ заходами держаного впливу, що спрямовані на виправлення неповнолітньої особи в подальшому [236].

Відповідно до ст. 28 КПК України, кримінальне провадження щодо неповнолітньої особи має бути здійснено невідкладно i розглянуто в суді першочергово [232]. Щоб зробити прогноз доцільності та подальшої ефективності застосування до неповнолітнього примусового заходу виховного характеру, суд повинен володіти достовірною інформацією щодо широкого кола обставин. На думку Кареліна Д.В., доречним буде закріпити в законодавстві складання «соціальної доповіді» під час розслідування проваджень щодо неповнолітніх, яка повинна включати в себе: соціально-демографічні дані про особу неповнолітнього правопорушника; відомості про склад сім'ї, характеристики на неповнолітнього та членів родини; характеристика про вчинене протиправне діяння, дані про негативні (наприклад, моральна чи матеріальна шкода) та позитивні (наприклад, відшкодування завданої шкоди) обставини, що відносяться до поведінки правопорушника; характеристика середовища неповнолітнього - коло друзів, знайомих, сусідів, порядок проведення вільного часу, характеристика 3 місця навчання/роботи); дані про рівень фізичного, психічного, інтелектуального, емоційного розвитку тощо [237].

Враховуючи викладене, доцільним було б доповнити словами «судовою соціальною доповіддю» ст. 497 КПК України у частині 1, а саме: «якщо під час досудового розслідування прокурор дійде висновку про можливість виправлення неповнолітнього, який обвинувачується у вчиненні вперше кримінального проступку, необережного нетяжкого злочину без застосування кримінального покарання, він складає клопотання про застосування до неповнолітнього обвинуваченого примусових заходів виховного характеру разом із судовою соціальною доповіддю і надсилає його до суду» [232]. Вважаємо, такі б зміни покращили порядок судового розгляду щодо неповнолітніх. 
Правове виховання неповнолітнього правопорушника повинно бути пропорційним впливу на його особистість відповідно до реальної необхідності. Тому роль примусових заходів виховного характеру полягає, насамперед, в урахуванні сукупності соціальних процесів і явищ, за допомогою яких держава впливає на стан злочинності серед неповнолітніх. I саме від цього залежить майбутнє нашої країни. 


\section{SECTION 15. THEORY AND HISTORY OF STATE AND LAW}

\section{1 Губернське управління на українських землях у складі Російської Імперії (кін. XVIII - 60-ті рp. XIX ст.)}

Відсутність власної держави та входження територій сучасної України до складу різних імперій протягом тривалого часу зумовили те, що на цій території запроваджувалась та діяла система загальноімперських органів місцевого управління та суду. Створені адміністративні структури забезпечували стабільність на новозахоплених територіях, своєчасне та у повній мірі справляння податків та повинностей, а також виконання інших завдань. Після захоплення українських земель Російською імперією верховна влада вдалася до уніфікації місцевого управління 3 внутрішніми губерніями, запровадження губернського устрою, який, щоправда з певними змінами, зберігся до 1917 p.

Згідно губернського адміністративного устрою станом на 1835 р. на території Україна у складі Російської імперії були створені Волинська, Київська, Подільська, Катеринославська, Полтавська, Таврійська, Харківська, Херсонська, Чернігівська губернії.

Система адміністративних структур на українських землях у складі Російської імперії запроваджувалось згідно «Установ для управління губерній Всеросійської імперії» (1775 p.) Катерини II. Набуття їх чинності на привласнених територіях імператриця доручала виконувати генералгубернаторам, спеціально для цього призначених сановників, яким влада довіряла у політичному відношенні. Штатний розпис адміністративних структур схвалювався імператрицею окремо для кожної губернії. Лише після вирішення всіх адміністративних питань відбувалося урочисте відкриття губернії, яке за спостереженням московської дослідниці Л. М. Лисенко була добре продуманим і підготовленим заходом, розрахованим на те, щоб сформувати масову свідомість населення і, особливо, місцевої еліти [242].

Виконавча влада у губернії зосереджувалась у руках губернатора. Як начальник краю він забезпечував формування дієвого адміністративного апарату 
SCIENTIFIC APPROACHES IN JURISPRUDENCE

шляхом контролю за виборними посадовцями у місцеві органи влади та призначати чиновників у губернські установи. Забезпечити виконання рекрутського набору, розподіл і контроль за виконанням земських повинностей, зокрема ремонт доріг, мостів, переправ, утримання поштових установ тощо. Посиленої уваги губернаторів прикордонних губерній вимагав контроль за видачею паспортів на перетин кордону, вивозом фіксованого числа готівки. Для виконання поставлених верховною владою завдань губернатор створював власну канцелярію. Ця адміністративна установа була ефективним органом проведення державної політики, структура якого формувалася відповідно до поставлених завдань. 3 цією ж метою було впроваджено інститут чиновників 3 особливих доручень.

Більшість повноважень здійснював через губернське правління, приказ громадської опіки, місцеву поліцію, які він же очолював. Для зменшення об'єму влади в руках начальника губернії створювалось губернське правління, наділене значною владою. Воно, як і губернатор, управляло іменем імператора, оприлюднювало його укази. Прийняття важливих рішень мало б відбуватися спільно: губернатором з губернським правлінням і у тому разі, якщо їх погляди не збігалися - записувались окремо, як особлива думка. Створена установа наділялась повноваженнями, що робило її здатною протидіяти губернатору.

Місцевим органом фінансового управління ставала казенна палата, яку до 1837 р. очолював віце-губернатор, а потім - спеціально призначений чиновник. Вона організовувала й контролювала надходження податків до державної скарбниці, стягнення недоїмок 3 несумлінних платників через губернське правління, здійснювала заходи по організації підрядів та торгів на надання винних відкупів. Їй також належали загальний нагляд за фабриками і заводами на території губерній, організація хлібних та фуражних зборів на військові потреби. У ï віданні перебувало будівництво і утриманням казенних будівель, мостів, перевозів [246]. 
SCIENTIFIC APPROACHES IN JURISPRUDENCE

У кожному повіті засновувались повітові казначейства, що підпорядковувались казенній палаті. Вони були касовими установами, до повноважень яких відносились приймання, збереження і видача коштів.

Прикордонне розташування губернії, запровадження військового стану змушувало дещо розширювати повноваження губернських, повітових адміністративних та фінансових органів влади, запроваджувати густішу їх мережу. Для прикладу, 26 вересня 1795 р. у складі Волинської казенної палати було створено додаткову військову експедицію, яка здійснювала збір продовольства та фуражу для забезпечення армії. Крім того вона проводила ревізії для перевірки виконання умов орендарями конфіскованих маєтків інвентарів та контрактів [239]. Подібні за функціональним призначенням були відкриті лише при катеринославській, вознесенській, подільській і брацлавській казенних палатах [238]. Забезпечення стабільності на присвоєних територіях було завданням першочергової ваги.

Для здійснення судочинства відкривались станові судові органи, ієрархія та чисельність яких відповідала моделі внутрішніх російських губерній. Вищими судовими інстанціями губернії були палати кримінального та цивільного суду; судові справи дворян розглядав повітовий та верхній земський суд, купців і міщан - магістрати і ратуші, державних селян - верхня і нижня розправи. Поза загальною судовою системою перебував совісний суд, який не лише карав, а й примиряв конфліктуючі сторони на умовах, які ті самі пропонували. За наміром Катерини II, вони покликані були виховати в порушників почуття відповідальності за скоєні злочини, залучаючи до осуду громадськість, родину, церкву. Здійснювали судові повноваження виборні з дворянської корпорації, міщанської і селянської громади [247].

3 названих судів у губернському місті, який визначався за рішенням імператора, запроваджувались палати кримінального і цивільного суду, верхній земський суд, губернський магістрат, верхня розправа. Повітових судів, нижніх земських судів, міських магістратів відкривалось згідно з кількістю повітів, за 
винятком нижніх розправ, яких відкривалося за рішенням губернатора, залежно від кількості державних селян.

Контролював дотримання законності місцевими установами губернський прокурор та стряпчі казенних та кримінальних справ. Прокурор зі стряпчими також запроваджувались при земських та надвірному судах. По одному стряпчому відправлялись у всі повіти губернії. На них покладалося трактування нових указів верховної влади, контролювати, аби місцеві установи здійснювали повноваження, окреслені законодавством, не затримували з'ясування термінових справ. Прокурор здійснював ревізію в'язниць, стежив за утриманням арештантів, крім того був уповноважений пришвидшувати розгляд справ ув'язнених. Для цього він міг брати участь у засіданнях судів, а також інших присутствених місць губернії [241].

Місцевим органом соціального спрямування був Приказ громадської опіки, обов'язком якого було опікуватися школами, сирітськими будинками, лікарнями, будинками для пристарілих, поранених та покалічених, несповна розуму. Значну увагу він приділяв функціонуванню шкіл та училищ 3 метою поширення російської освітньо-культурної мережі. Він також функціонував, як важлива кредитна установа, оскільки розпоряджався одноразово виділеними державними коштами та надавав їх дворянам у борг під заставу маєтків. У західних губерніях Російської імперії (Київській, Волинській, Подільській) верховна влада розширила його службовий склад - було введено до його штатного розкладу губернського предводителя дворянства.

Приказу громадської опіки підпорядковувалися місцеві лікарні. Доктор, лікар, підлікар та лікарські учні були уповноважені стежити за станом здоров'я населення, відповідали за прийняття швидких і дієвих заходів у разі поширення епідеміологічних хвороб, розповсюджували серед населення знання про гігієну і здоров'я, про способи запобігання хворобам [246].

У повітах створювались повітовий та нижній земський суд, у яких функції поліцейські і судові поєднувалися. Там же відкривалися дворянська опіка та нижня розправа. Вищу повітову адміністративно-поліцейську посаду обіймав 
земський справник, що обирався дворянством кожні три роки. Він зобов'язаний був контролювати дотримання громадської безпеки, своєчасне та у повному обсязі надходження державних податків і викупних платежів. До кола його повноважень входила відповідальність за стан доріг, переправ, перебування військ, пожежну безпеку. Він же мав заохочувати населення до землеробства, працьовитості, створення хлібних запасів. Саме тому справник також очолював земський суд 3 правом призупиняти його рішення [248]. Таким чином він був повноправним помічником губернатора у повіті, але фактично залежав від місцевих дворян, оскільки ті його обирали. Для нейтралізації цієї посади від впливу місцевої знаті, не завжди лояльно налаштованої до верховної влади імперії та для посилення контролю за повітовими установами Павло I 14 жовтня 1799 р. видав указ, за яким у західних губерніях земські справники почали призначатись начальником губернії [244].

Для управління містами на українських землях у складі Російської імперії запроваджувались традиційні для імперії установи. Внаслідок цього ті ставали центрами адміністративної, судової, військової та релігійної влади, відтак користувалися перевагами у проведенні ярмарків та встановленні пунктів стаціонарної торгівлі, яка заборонялась у селах. Згідно «Жалуваної грамоти містам» (1785 р.) у губерніях створювалися магістрати, сирітські суди, загальні міські думи та виконавчі органи - шестигласні думи. Городничий призначався у повітове місто для забезпечення виконання законів і указів, контролював виконання рішень судів. Він, як і повітовий справник, стежив за належним станом мостів, вулиць та казенних будівель, що перебували на території міста. У його розпорядженні перебувала штатна команда з військових та міська поліція, спираючись на які, він забезпечував стабільність [246].

Магістрати поєднували і судові, і адміністративні функції. Вони вирішували кримінальні та цивільні справи міщан, наглядали за стягненням податків, продажем міських будинків чи інших споруд, що належали місту. Магістрати проводили перепис місцевих купців 3 детальним роз'ясненням їх матеріального становища, про що повідомляли губернське правління та казенну палату. 
Остання забезпечувала їх для цього спеціальними ревізійними книгами. Засновані при кожному магістраті, сирітські суди опікувались купецькими та міщанськими вдовами, сиротами [246].

Органом міської влади являлась дума, до складу якої входили голова та виборні від кожної міської верстви. Вона засідала раз на три роки та у разі потреби з'ясувати термінові завдання [243]. На міську думу верховна влада покладала здійснювати загальний нагляд за продовольчим станом у місті, та нести відповідальність за стабільність у ньому та його передмісті [240]. А для цього до кола її повноважень відносилось забезпечення безперебійної торгівлі. Оскільки міська дума була юридичною особою з правом власності, то у іiі безпосередній відповідальності перебували міські будови. Вона ж покликана була не лише ремонтувати старі, а й будувати нові.

Під час запровадження губернської моделі управління на українських землях верховна влада стикалась 3 невластивими для неї питаннями. Зокрема. Після захоплення територій колишньої Речі Посполитої, імперська влада була змушена налагоджувати стосунки не лише 3 шляхтою - місцевою елітою, а й рахуватися 3 проживанням значної чисельності єврейського етносу. До приєднання цих земель Російська імперія не мала досвіду налагодження взаємовідносин з євреями, оскільки до цього часу чисельність їх була незначною. Ситуативна модель їх поведінки вимагала від органів влади цілеспрямованої політики й тому указом від 23 липня 1794 р. Катерина II намагалася розселити їх по містах і містечках, зареєструвати у міських книгах і підпорядкувати місцевим магістратам. Євреям дозволили користуватися торгами та міщанськими промислами, заохочувалась їх співпраця у традиційних для них сферах торгівлі, оренди, позики. Їх заняття рукоділлям і ремеслами мало пожвавити місцеву торгівлю та розвиток міст. Було збережено орган самоврядування єврейської общини - кагал, який раніше виконував податкові, адміністративні, судові, культурні та релігійні функції.

Правління імператора Павла I внесло зміни у схему територіального поділу Російської імперії та склад адміністративних органів і чиновницького апарату. 3 
12 грудня 1796 р. намісництво, як територіальна одиниця, виводилась з ужитку 3 ліквідацією інституції генерал-губернаторства. На територіях, які потребували додаткового силового контролю, Павло I призначив військових губернаторів. Зокрема, 1796 р. було засновано канцелярію подільського військового губернатора, якому в питаннях цивільного управління підпорядковувалися Подільська, Волинська та Мінська (до 1801 р.) губернії. Їх повноваження окреслювались статутом «Про польову піхотну службу», виданому 29 листопада 1796 р., які у загальних рисах співпадали 3 функціями комендантів, а для забезпечення адміністративного регулювання їм підпорядковувалась місцева поліція. Особливими розпорядженнями на них покладалося і адміністративне управління. Від військових губернаторів верховна влада вимагала координувати цивільних, забезпечувати стабільність та благополуччя у ввіреному краї. Їх надзвичайну роль підтверджувало отримане право звертатись особисто до імператора з пропозиціями про благоустрій губерній - прерогатива колишніх генерал-губернаторів.

За розпорядженням Павла І скасовувалися середні судові інстанції, а також нижні розправи, замість кримінальної і цивільної почала діяти палата суду та розправи (Штати). Було скорочено склад казенної палати, нижнього земського суду та приказу громадської опіки. До останнього входили лише губернатор та губернський предводитель дворянства, а канцелярських службовців призначали з інших присутствених місць губернії. У повітах скасовувалася посада повітових землемірів, стряпчих, а число прокурорів скоротилось до одного - губернського.

Щоб здешевити державний апарат управління, утримання судів покладалось на місцевих дворян, які оплачували службу радників та асесорів головного суду, повітових та нижніх земських судів 3 їх канцеляріями, губернських i повітових землемірів, архітекторів, механіків, медичних чиновників та повивальних бабок лікарських управ. Для прикладу з дворян (шляхти) Волинської губернії на ці потреби щорічно збирали 63 тис. руб., у Литовській губернії - 104 тис. руб., у Київській - 72 тис., а у внутрішніх 
SCIENTIFIC APPROACHES IN JURISPRUDENCE

губерніях ця сума не перевищувала 50 тис. [245]. Магістрати повністю утримувались за кошти міських жителів.

Щодо українських земель, які захопила Російська імперія внаслідок Речі посполитої, то Павло I надав губерніям статус «особливих прав і привілеїв». Внаслідок цього до кінця його правління діяли сеймики, дворянським посадам поверталися колишні назви, запроваджувалися посади фіскалів. Однак зміни проіснували лише до кінця його правління. Верховна влада не бажала запроваджувати на українських землях відмінної організації влади, а навпаки пришвидшувала запровадження місцевих загальноімперських органів, аби якнайшвидше здолати опір і пришвидшити асиміляцію місцевих еліт.

Російська імперія для опанування територіями сучасної України використовувала не лише армію, а й державний апарат влади. Склад, структура та функції державних інституцій були такими, що практично не відрізнялися від внутрішніх губерній. Лише враховуючи етно-соціальні особливості земель, прикордонне розташування деяких губерній та перебування там значної чисельності військ змусили верховну владу створювати додаткові функціонально-структурні частини в межах запроваджених губернських установ або призначати додаткових чиновників. Однак губернська модель управління існувала тривалий час і забезпечувала виконання загальнодержавних завдань. 


\section{2 Від софістів до Г. Гроція: концептуалізація природного права}

Відомий американський політолог минулого століття Роберт Беркі, формулюючи концепцію періодизації політичних вчень від їх виникнення до XX століття, назвав нашу епоху, останньою в його переліку, соціальною епохою. Він вважав, що основним критерієм вказаної періодизації є так званий «дух часу»сукупність основних, стрижневих, концептуальних для кожного історичного періоду ідей, навколо яких розгортаються усі політичні вчення даного періоду. В «духові часу» концентрується, таким чином, те основне, що притаманне кожному історичному часові, кожній історичній епосі політичної думки. «Дух часу» - це такі собі «окуляри», «лінзи», через які як індивід, так і уся людська спільнота сприймають навколишній світ, своєрідне «бачення» світу у його найголовніших вимірах - онтологічному, аксіологічному, політико-правовому, світоглядно-духовному тощо. Назвавши нашу епоху «соціальним духом часу», американський дослідник окреслив головне в ній - права і свободи людини.

Дійсно, якщо простежити основні політичні тенденції останніх десятиліть, то ми можемо твердо говорити про те, що тенденція практичного ствердження прав і свобод громадян сьогодні стала пріоритетною для достатньо великої частини людства. Очевидно, повною мірою вона була актуалізована прийняттям Генеральною Асамблеєю ООН Загальної декларації прав людини 10 грудня 1948 року. Мабуть, не останньою причиною народження цього величного документа в історії людської цивілізації були дві світові війни, які забрали десятки мільйонів людських життів. Одночасно вони продемонстрували надзвичайну крихкість людського буття в контексті переслідування інтересів політичних еліт, націй, держав тощо. Особливої уваги заслуговує низка подій початку нового тисячоліття, свідками яких ми $є$ сьогодні і які ще більше загострюють як проблему прав і свободи людини в цілому, так і особливо питання щодо природних прав людей. Очевидне зростання суверенізму, новітні тенденції наростання волюнтаризму та авторизму у деяких провідних країнах світу (Росія, Китай, США тощо), певною мірою розчарування ліберальною ідеологією і 
SCIENTIFIC APPROACHES IN JURISPRUDENCE

демократією, що зумовило ревізію їх базових положень, відкрите нехтування нормами міжнародного права з боку сильних світу цього виносять проблему прав i свобод людини на новий рівень. В цьому контексті звертання до теми природного права людини є не тільки виправданим, але й необхідним.

Разом $з$ тим, я не буду оригінальним, якщо скажу, що вказана вище тенденція зростаючої актуалізації та політико-юридичного конституювання проблеми прав і свобод людини має грунтовні корені в історії. Остання демонструє нам низку фундаментальних правових документів глибокої давнини, які справили величезний вплив на розвиток людської цивілізації. Серед них, зокрема Кодекс Хаммурапі (Зведення законів Хаммурапі) - один з найдавніших i найкраще збережених законодавчих документів стародавнього Вавилону, створений близько 1780 року до нашої ери. Цей грунтовний правовий документ регулював практично усі сфери тогочасного життя: цивільні, трудові, шлюбносімейні, кримінальні, кримінально-процесуальні, зобов’язувальні тощо. Незважаючи на те, що основна частина Кодексу Хаммурапі стосувалась покарань, в тому числі смертної кари за порушення закону або нечесні вчинки, в цілому він був, безсумнівно, спрямований на правове улаштування життєдіяльності тогочасного суспільного організму, без якого останній не мав би можливості виживання.

Ще однією важливою віхою на шляху правової організації людського суспільства стало створення так званого Римського права - правової системи стародавнього Риму, яка діяла практично на усьому протязі існування Римської держави: в царський період, республіканський та в часи імперії. Функціонування Римського права захопимо величезний період у розвитку західноєвропейської людності, починаючи від Законів Дванадцяти таблиць, що були створені в середині V століття до нашої ери, і до Кодексу Юстиніана (529 рік). Це - епоха в більш ніж тисячу років, епоха, яка послужила основою правових систем у Західній Європі, а також у Східній Римській імперії.

Потрібно особливо відзначити Велику Хатію вольностей (Магна Карта), підписану 15 червня 1215 року королем Англії Іоаном Безземельним та скріплену 
SCIENTIFIC APPROACHES IN JURISPRUDENCE

його печаткою. Цей непересічний документ - фактично перша неписана конституція Англії, яка регулювала права і привілеї феодальної знаті, надавала свободи церкві та зобов'язувала короля дотримуватись законів. Велика Хартія вольностей, очевидно, також один з перших в історії європейської цивілізації, та і усього людства документ, що народився в результаті гострої боротьби певних верств тогочасного англійського суспільства за свої права і свободи, яким до того монопольно розпоряджався король Англії. Зокрема, Хартія закріпила право приватної власності, недоторканості та свободи людини від королівського абсолютизму. Велика Хартія вольностей стала грунтовним прологом для наступних віків, зокрема, епохи Відродження, яка принесла в західноєвропейську культуру ідеї людини, індивідуальності, віротерпимості і свободи, законодавчо закріплені у низці європейських країн. Можна також згадати декларацію прав людини і громадянина (Франція, 1789 рік) і Білль про права (США,1791 рік), і інші документи. Всі вони внесли свою частку в той процес, який виріс у наш час у світову тенденцію.

3 іншого боку, варто зазначити, що вказані вище документи, як і сама Загальна декларація прав людини та інші, що були проголошені пізніше, виникли не на порожньому місці. 3 давніх давен звичайні люди, а тим більше інтелектуали різних країн та епох розмірковували над феноменом прав людини. Що є право за своїм змістом і суттю. Яке воно є від природи, незалежно від людського встановлення? Чи існують об'єктивні, незалежні від самих людей та держави, онтологічні та ціннісні критерії, що дозволяють з максимальною достовірністю відрізнити праве від неправого, право як таке, від природи від права, встановленого державою? Якщо ж такі критерії існують, то як їх виявити, обгрунтувати і практично застосувати?

Здавалося б, абстрактні, відволікаючі та спекулятивні питання, які дуже далекі від життя і годяться лише для непотрібних, схоластичних дискусій. Питання, які, здається, зовсім не стосуються реального життя тисяч і мільйонів людей. Однак ні. В соціальній, політичній та і в усій людській реальності за цими питаннями чітко проглядається практика життя, яка щоразу, як тільки виникають 
правові колізії, повертає до них не лише окремих людей, але й соціальні групи, народи, нації.

Більше того, «проза» життя, як не дивно, дуже часто ставить питання не просто про права і свободи. Рано чи пізно вона занурюється так глибоко, що викликає до роздумів головне в них: чи є взагалі в людей підстави для права людини? Ось чому варто стверджувати, що за усієї глибини феномена прав і свобод людини та різноманітності його вимірів і багатств методологічних підходів незмінним залишається одне: все починається з теми природного права. У якому б ракурсі дослідники не розглядали тему людських прав і свобод, вони ніяк не можуть оминути проблему природного права як фундаментального виміру цієї багатогранної теми. Саме цим пояснюється мій дослідницький інтерес.

Тема природного права є однією з найдавніших в історії багатьох наук про державу і право: політичної науки, політичної філософії, юриспруденції тощо. Це і не дивно: як тільки людина навчилася усвідомлювати себе як істоту, природним станом існування якої є колективність, соціальність - відтоді логічно i об'єктивно вона ставить питання про права, їх природу, межі та способи втілення. В цьому контексті вельми цікавою виглядає, на мій погляд, методологічна лінія дослідження проблеми природних прав у західноєвропейській інтелектуалістиці від давньогрецьких інтелектуалів до мислителів Нового часу, а фактично від софістів до Гуго Гроція. Перші фактично започаткували теоретичний аналіз природного права, другий сформулював його бачення на основі раціоналістичної методології і конституював як засадну основу практичної життєдіяльності людини.

Якщо спробувати вирізнити певні вузлові моменти наукових розвідок проблеми природних прав у давній соціально-філософській науці, то можна впевнено назвати софістів та Арістотеля. Більшість сучасних дослідників цієї теми навіть не дискутують з приводу такого висновку. Звичайно, різні думки щодо громадянських прав можна зустріти і у тих мислителів, які жили і творили як до софістів, так і після них. Однак, визнаною є думка про те, що в історії 
SCIENTIFIC APPROACHES IN JURISPRUDENCE

хзахідноєвропейської цивілізації час актуалізації проблеми природного права припадає на V-IV століття до нашої ери - початковий період фактичного розквіту давньогрецьких полісів, давньогрецької демократії та давньогрецької інтелектуалістики. А саме виникнення теми природного права починається зі спроб розрізнення між правом природним і правом позитивним. Перші приклади цього ми бачимо вже у Гесіода, «семи мудреців» та Геракліта. Так, Гесіод, оспівуючи створених богами перших людей, говорить про права і свободи цих людей, які повною мірою втілювалась і були рівні для всіх. «Жили ті люди, як боги, зі спокійною, і ясною думкою, горя не знаючи, не знаючи трудів. I журлива старість до них наближатися не сміла. Завжди однаково сильні були їх руки i ноги. В пірах вони життя проводили. А вмирали, як начебто обійняті сном. Нестача була їм ні в чому не відома. Великий врожай і пишний самі давали собою вдячні землі. Вони ж, скільки хотілося, працювали, спокійно збираючи багатства, - стад володарі багатьох, люб'язні серцю розкішних...» [250]. Однак, зазначає поет, прийдуть часи, коли «турботи важкі боги дадуть їм... Діти з батьками, 3 дітьми - їх батьки зговоритися не зможуть. Чужими стануть товариш товаришу, гостю - господар. Більше не буде між братами любові, як бувало колись. Старих батьків скоро зовсім поважати перестануть... Правду замінить кулак... Скоріше нахабі та лиходію стане пошана віддаватися» [251].

Думки щодо природного права можна знайти і в інших інтелектуалів Давньої Греції. Так, у Геракліта з Ефесу зустрічаємо такий вислів: «Мудрість полягає в тому, щоб говорити істину і прислуховуватися до голосу природи, чинити згідно з нею» [252]. Щось подібне висловлював і Парменід, коли він ототожнював думку і те, про що існує думка. «Одне і те саме, - писав він, - $\epsilon$ думка і те, про що думка існує. Оскільки без буття, в якому їі вираз, думки тобі не знайти» [253]. Набагато пізніше вказаних авторів римський юрист Гай визначив природне право як «право, що природний розум встановив між усіма людьми» [254]. Один 3 видатних інтелектуалів Давнього Риму, філософ i теоретик держави Ціцерон також не оминув тему права та природи. Зокрема, він писав: «Ми маємо розтлумачити природу права, яку слід шукати в природі 
SCIENTIFIC APPROACHES IN JURISPRUDENCE

людини» [255]. I далі: «Вчені мужі визнали за потрібне виходити з поняття закону. I вони...мають рацію, - за умови, що закон (як вони і визначають його) закладений у природі найвищим розумом, який велить нам чинити те, що слід чинити, і забороняє протилежне...Бо закон є силою природи... Виходимо ж при обгрунтуванні права $з$ того найвищого закону, який (бувши спільним для всіх віків) виник раніше, ніж будь-який писаний закон, точніше, раніше, ніж будь-яка держава взагалі була заснована» [256]. Можна процитувати і інших авторів стародавнього світу, однак зазначу, що це були лише окремі думки і в інших контекстах. Цілісний ж і певною мірою кумульований підхід до проблеми все ж таки вперше зустрічається у софістів.

Тема природного права виникла у софістичній думці, очевидно, не випадково. Вважається, що цей напрям давньогрецької філософії чи не вперше в історії стародавньої Західної Свропи поламав усталену на той час (середина V 1 половина IV ст. до н. е.) традицію розглядати головним об'єктом своїх роздумів навколишній світ - природу, космос, всесвіт. Софісти перші заговорили про людину як стрижневе явище світу, як вирішальний об'єкт уваги мудреців. Такий підхід, як відомо, виразився у знаменитих словах Протагора, які дійшли до наших днів: «Людина $\epsilon$ мірою усіх речей: існуючих, що вони існують, i неіснуючих, що вони не існують» [257]. А відтак, зробивши людину осердям буття і головним предметом філософських розмислів, софісти рано чи пізно мали прийти до питання про іiі сутнісні ознаки як істоти. Тема природного права, як мені видається, - закономірний наслідок того світоглядно-гносеологічного повороту, який здійснили софісти.

Проблема природного права виникла у софістів у зв'язку і з ще однією особливістю їх філософствування. Представники цього інтелектуального напрямку виходили з ідеї про відносність всього існуючого. Платон у своїх коментарях щодо Протагора зауважує, що той вважав речі такими, якими вони являються людині. «Протагор казав, - зауважує Платон, - що міра всіх речей $є$ людина, тобто якими речі являються мені, такими вони і суть для мене, а якими (вони являються) тобі, такі вони для тебе» [258]. Подібний коментар думок 
Протагора ми знаходимо і у Секста. «Протагор...мірею називає критерій, речами ж- справи/ те, що робиться/; таким чином, він стверджує, що людина є критерій усіх справ: існуючих, що вони існують, неіснуючих, що вони не існують. I внаслідок цього він приймає тільки те, що являється кожній/ окремій людині/, i таким чином вводить/ принцип/ відносності...» [259]. Це означає, що насправді світ $\epsilon$ не таким, яким він $\epsilon$, а $є$ таким, яким він являється конкретній людині. Тому, що кожен людський індивід володіє як від природи, так і в залежності від своєї соціальності такими природними і соціальними силами, які роблять його особливим, унікальним, неповторним, одне слово - індивідуальним. I саме неповторний набір природних і соціальних якостей дають можливість кожному 3 нас сприймати, розуміти і тлумачити речі, явища, предмети, процеси навколишнього світу і самих себе так, як це можемо лише ми як окремішне, індивідуальне, неповторне. Ось чому у поглядах на конкретні речі чи на весь світ не може бути єдиної думки. Софісти звели істину до суб'єктивності конкретної людини, посиливши свій висновок про те, що все відносне.

3 іншого боку, теза про відносність речей і світу привели представників давньогрецького софізму до думки про відносність людського буття. А оскільки це так, то і права і свободи людини є відносними. Тоді виникає логічне питання про те, чи є взагалі в людському існуванні щось вічне, стабільне, таке, що не піддається змінам. Саме цей контекст логіки софістів вивів їх на проблему природного права.

В контексті вищесказаного можемо сформулювати два висновки. Перший полягає в тому, що права людини є відносними, як і усе в світі. Другий актуалізує питання про існування незмінних, вічних людських прав. У цьому контексті відзначимо два вузлових досягнення софістів. Перше пов'язано з введенням в науковий вжиток поняття «природне право», «право природи», а друге відповідно до цього, полягало у розведенні понять «природне право» i «позитивне право». Щодо останнього, то його софісти розуміли як право, яке отримується людиною в залежності від того суспільного середовища, в якому вона здійснює свою життєдіяльність. В цьому випадку право людини не є 
стабільним, вічно однаковим, на його зміст впливає низка найрізноманітніших за своїм походженням, силою, способами і формами прояву суспільних чинників. Серед них як об'єктивні, так і суб'єктивні. Позитивне право, таким чином, не завжди відповідає людським потребам, оскільки його зміст - суть інтегральне від багатьох факторів. Швидше за все, його зміст визначається пріоритетом тих чи інших групових інтересів у конкретних умовах. Це означає, що таке право практично ніколи не може бути ідеальним щодо справжніх людських потреб, бо воно - результат конкуренції багатьох сил, особливо у політико-державному смислі.

По-іншому розглядали софісти феномен природного права. Вони вважали, що таке право випливає 3 природи людини як істоти, а тому завжди $\epsilon$ виправданим, правильним, істинним, бо виражає людську природу. Знову наведу слова Протагора. «Люди, - пише він, - в різний час сприймають по-різному, в залежності від відмінності своїх станів. А саме той, хто живе за природою, сприймає те із існуючого в матерії, що може явитися як таке, що живе за природою, ті ж, що живуть протиприродно - те, що може являтися як таке, що живе протиприродно» [260]. Протагор вважав цей принцип універсальним для людського буття, а тому таким, що поширюється на будь-які зрізи, виміри, сфери життєдіяльності людини. Згадуваний вище Секст наводить його думку так: «I точно те ж саме вчення дається і стосовно віків, і відносно сну або неспання, i про кожний вид стану/ людини/. Отже, згідно з його вченням, критерієм існуючого є людина. Бо все, що уявляється людям, то і існує...Отже, ми бачимо: i /в своєму вченні/ про текучість матерії, i /у вченні/ про те, що причини усіх явищ лежать в матерії, він тримається догматичних поглядів» [261].

Цікавим є також аналіз двох основних течій софістичного трактування природного права. Незважаючи на те, що в основу вказаного феномену представники цього напрямку брали людську природу, висновки вони виводили різні. Тезу про рівне природне право відстоювала егалітаристська течія, найвидатнішими представниками якої можна вважати Гіппія, Алкідаманта, Лікофрона тощо. Ці мислителі стверджували, що всі люди за своїми природними 
SCIENTIFIC APPROACHES IN JURISPRUDENCE

правами рівні, незалежно від місця народження, сімейного чи майнового походження. Основа такої рівності - подібність людей за природою. Звідси необхідність людської взаємоповаги, солідарності, взаємостраждання, підтримки одне одного. Звідси ж - заперечення насильства, несправедливості, різного роду соціальної нетерпимості між людьми тощо. Яскравою ілюстрацією такого розуміння природного права є слова Гіппія, які наводить Платон у своєму діалозі «Протагор». Роблячи спробу не доводити гостру розмову між Сократом і Протагором до крайньої форми, цей філософ бере слово і промовляє: «Мужі, які тут зібралися! Я вважаю, що ви усі тут родичі, свояки і співгромадяни за природою, а не за законом: адже подібне є родинним подібному за природою, закон же - тиран над людьми - змушує до багато чого, що гидко природі» [262] Іншою ілюстрацією вказаної позиції $\epsilon$ слова Антифона Афінського давньогрецького філософа, одного із представників старшого покоління софістів. Він стверджував, що за природою людські відносини однакові як у варварів, так і в еллінів, в усіх людей потреби від природи однакові [263].

Друга течія софістичного розуміння природного права $\epsilon$ антиегалітаристською і представлена такими іменами, як Горгій, Крітій, Каллікл та інші. Ці мислителі вважали, що рівне природне право усіх людей, разом з тим, об’ єктивно і справедливо породжує нерівність. Адже усі люди неоднакові у своїх біологічних вимірах. Хтось, наприклад холерик, хтось сангвінік. Один має одну фізичну силу, інший - іншу. Такі роздуми привели вказане крило софістів до висновку про виправдану необхідність соціальної нерівності людей. У діалогу «Горгій» Платон наводить слова Каллікла: «...Закони якраз і встановлюють слабосильні, а їх більшість... Прагнучи залякати більш сильних, тих, хто здатен над ними піднестися, боячись цього піднесення, вони стверджують, що бути вище інших соромно i несправедливо, що в цьому якраз $\mathrm{i}$ полягає несправедливість - в прагненні піднятися вище інших... Ось чому звичай оголошує несправедливим і ганебним прагнення піднятися над натовпом, i це зветься у людей несправедливістю. Але сама природа, я думаю, проголошує, що це справедливо - коли кращий вище гіршого і сильний вище слабкого» [264]. 
SCIENTIFIC APPROACHES IN JURISPRUDENCE

Звернусь тепер до Арістотеля. Його філософське вчення справедливо вважають вершиною всієї античної філософії. В контексті даної теми можна стверджувати те саме: концепція природного права найуспішніше розгорнута саме цим давньогрецьким мислителем. Джордж Себайн і Томас Торсон у своїй книзі «Історія політичної думки» пишуть: «Теорія природи в такому вигляді, як вона виникла з біологічних та соціальних досліджень, була потрібна Арістотелю для того, щоб забезпечити логічну основу для сформульованої науки й мистецтва політики. Природа - це глибинна система можливостей або сил розвитку, що спрямовується їхньою іманентною сутністю до тільки для них означеного кінця. Вони вимагають для свого розвитку того, що можна назвати матеріальними умовами, які не приводять до кінця, на який спрямовується розвиток, але можуть допомагати або заважати розвитку, залежно від того, чи вони сприятливі, чи ні. Події і зміни, які безперервно відбуваються, - це процес, за якого сили росту починають оволодівати потрібними для свого розвитку умовами. Ці три фактори, названі Арістотелем формою, матерією $\mathrm{i}$ рухом, $\epsilon$ фундаментальними складовими частинами природи» [265]. Сама ж природа опредметнюється лише через рух або зміну. К. Поппер, коментуючи Арістотеля, зазначає: «За Арістотелем, кожен рух або зміна означають реалізацію (чи «актуалізацію») певних потенційних можливостей, властивих внутрішній сутності речі» » [266] Сама ж природа, як пише Арістотель, «в первинному і власному смислі $є$ сутність, а саме сутність того, що має начало руху в собі самому як такому» [267]. I іншому місці він пише: «Адже і природа належить до того самого роду, що і здібність; вона начало руху, але не в іншому, а самій речі, оскільки це само річ» [268].

Головні думки Арістотеля щодо сутності природних прав людини висловленні в його відомому творі «Нікомахова етика», де він формулює поняття «право від природи», співвідносячи його з поняттям «право не від природи», тобто правом, яке встановлюється самими людьми, їх організацією, способом спільного існування. «Право від природи» вважається, за думкою Арістотеля, таким, якщо воно «всюди має однакову силу і не залежить від визнання чи 
невизнання його людьми». Інше ж право, «право не від природи» або «право за законом і угодою»встановлюється людьми, а тому грунтується на їх спільній злагоді та спільній вигоді. Цю частину державного права Арістотель порівнює 3 мірами для вина і хліба, які не всюди однакові: у скупника вони більші, у дрібних торговців - менші [269].

Таким чином, Арістотель так само, як і його попередники, зокрема софісти, вважав природним правом таке право людини, яке зумовлене іiі природною організацією. Однак у питанні щодо трактування самої людської природи його думки корінним чином відрізнялися від поглядів своїх попередників. Зокрема, мова іде про питання сталості чи змінності цієї природи. Арістотель категорично заперечував існування сталої, незмінної та вічної людської природи. Навпаки, він доводив її змінність. Так само, як увесь світ перебуває в розвитку, так само людська природа розвивається, наполягав Арістотель. А це значить, що зафіксувати справжню людську природу можна не завжди, а лише в моменти іiі найвищого, досконалого стану. «Ми називаємо природою кожного об'єкта той його стан, - зауважує мислитель, - який виходить при завершенні його розвитку» [270]. Як приклад, Арістотель порівнював сім'ю і державу. В контексті виявлення природності людського буття він називав справжньою і найвищою формою їі реалізації державу, тоді як сім’ю вважав недорозвиненою формою. Д. Себайн та Т. Торсон, коментуючи думки Арістотеля, пишуть, що кожна рослина, як вважав видатний грек, має свою природу, яка проявляється поступово. Таке саме пояснення можна застосовувати й до розвитку суспільства. У такій примітивній формі, як сім'я, воно проявляє свою істинну природу у поділі праці, але у своїх вищих формах воно виявляється здатним відкрити широкий простір для розвитку тих здібностей, які «дрімають» у окремій сім’ї. «Сім’я, - передають Д. Себайн та Т. Торсон слова Арістотеля, - передує в часі, але держава є першочерговою «за природою; вона повніше розвинена і ясніше відображає суть суспільства. 3 цієї ж причини життя в державі показує свою справжню людську природу» [271]. Адже людська природа характерніше проявляється в розвитку тих сил, які притаманні тільки людині. А отже, держава - це єдине середовище, 
SCIENTIFIC APPROACHES IN JURISPRUDENCE

в якому вони можуть розвиватися; це «природно» в державі, яка в деяких відношеннях протилежна інстинктивній природі. Як жолудю притаманно проростати в дуб, так само й людській природі властиво розвинути свої найвищі сили в державі [272]. Ось чому в логіку вписується відомий вислів цього давньогрецького філософа про те, що людина за своєю суттю є політичною істотою, тобто такою, справжня природа якої розгортається тільки завдяки державницькій формі їі буття.

Отже, на відміну від софістів або, наприклад, Платона, які вважали, що природне право є вічним і незмінним, Арістотель змінив погляд на цей феномен. Його позиція полягала в тому, що в дійсності природне право є і незмінним, $\mathrm{i}$ змінним. Незмінним воно є тому, що ніколи не змінює джерело свого існування - людську природу. В цьому плані Арістотель погоджувався з думкою про те, що природне право -це дзеркало людської природи, їі адекватний зміст. Крім того, таке право він вважав незмінним в тому смислі, що воно є найвищою цінністю, яка дається будь-якому представникові людського роду від народження i, значить, не може бути відчуженим ні при яких обставинах.

3 іншого боку, природне право є змінним, бо змінюється сама людська природа. Говорячи про софістів, Аристотель вказує, що їх думка про незмінність природного права правильна лише в тому смислі, якщо це право поширювати на богів. У цьому випадку змінність абсолютно виключена. Але серед людей «хоч і можливо щось праве від природи, все це, однак, змінне і разом з тим одне існує від природи, інше - не від природи» [273]. Тут великий грек розкриває джерело змінності природного права як внутрішній чинник, а не зовнішній. Тому що зовнішній по відношенню до людської природи чинник полягає в самій діяльності людей, а тому і покладається, в цілому, державою, ii законами. Змінність ж природного права покладається законами розвитку людської природи. Арістотель, таким чином, розкриває в «природі» внутрішнє джерело руху, саморозвитку, маючи на увазі, що все в світі, як у природному, так і в людському перебуває у вічному процесі виникнення, становлення, розквіту, занепаду і смерті. Коли ж він говорить про змінність природного права, то має 
SCIENTIFIC APPROACHES IN JURISPRUDENCE

на увазі вільний, нічим не обмежений рух, самостійний розвиток, який відбувається сам по собі, без зовнішніх впливів.

Арістотель корінним чином відрізняв природне право від права позитивного. Якщо останнє свою дієву, зобов'язальну силу черпає із встановленого людьми закону, то природне право позбавлене такого несправедливого тягаря. Сдиним мотивуючим чинником, дієвою, зобов’язальною силою для його практичного втілення є лише людська природа. Таким чином, природне право виражає не зовнішні фактори свого існування, а суто внутрішні. Воно не потребує і не вимагає опори на вартості, які знаходяться поза людською природою. В цьому плані природне право Арістотель характеризує як право досконале, ідеальне, найкраще. Воно розуміється давньогрецьким інтелектуалом як взірець для обгрунтування позитивного права, однак такий взірець, який ніколи не може бути досягнутий реальним правовим життям конкретного соціуму. Тому що уявити життя суспільства та його членів як цілковите слідування людській природі є недосяжним ідеалом. Нарешті, природне право Арістотель розумів як вічне, абсолютне і необмежене. Його єдиним обмеженням є людська природа.

Визначна роль Арістотеля у концептуалізації проблеми природних прав полягає також і в тому, що він зробив спробу сформулювати основні природні права людини. Базовим серед них він називав право на державницьке життя. Вище йшлося про державу як найвищу, досконалу форму прояву людської природи. Тут лише додам, що саму державу Арістотель розумів як найкращу форму людського спілкування і спільної життєдіяльності людей як істот. Власне кажучи, держава для Арістотеля - це не стільки орган управління, скільки універсальний спосіб розгортання колективістської сутності людської природи, досконала форма людської ієрархії. Того ж, хто навчився жити державницьким життям, давньогрецький філософ відносив до категорії людей. А той, хто живе поза державою, той в розумовому відношенні або надлюдина, або нелюд, - писав Арістотель. 
До основних природних прав людини давньогрецький мислитель відносив право власності. «Природним для всіх людей $є$ прагнення наживати статки 3 усяких рослин і тварин», - зазначав він [274]. На його думку, це природньо для будь-якої людини, яка прагне присвоювати і володіти. Так само природним для людини має бути протилежний процес - відчужування. Звідси - природне право людей на обмін результатами власної діяльності. Називає Арістотель і інші природні права, такі як право на їжу, на відпочинок, на удосконалення своєї душі та тіла.

I все ж, очевидно, найвищим, смисловим, кінечним природним правом людини Арістотель вважав право на вільну розумову діяльність. Цей висновок він зробив на основі ідеї найвищого досконалого розгортання людської природи, а таким $є$, безсумнівно, розумова, духовна сутність людини. На думку філософа, «природа нічого не чинить без цілі», а «природою ми називаємо кожен об'єкт: візьмемо, наприклад, природу людини, коня, сім’ї - той їхній стан, що утворюється при завершенні їхнього розвитку. Більше того: досягнення кінцевої мети означає найвище завершення, а самодостатнє існування $є$ і завершенням, $\mathrm{i}$ найкращим станом» [275]. Найкращою ж розумовою діяльністю є не кожна 3 них, а лише та, яка здійснюється невимушено, без зовнішніх впливів, за покликом душі і самого розуму. Таким природним правом Арістотель називав чисте споглядання, споглядання як блаженство.

Відродження відкриває нову епоху в західноєвропейській філософії в цілому, у політичній філософії, а особливо у філософії природних прав. «Вона не порушила встановлену ще греко-римською античністю i закріплену середньовіччям градацію теоретичних і практично-життєвих вартостей. Як i раніше, в числі найважливіших філософських проблем перебуває Бог, світ, людина, іiі чесноти тощо. В цілому - буття суспільства і його взаємини 3 індивідом. Однак специфічність Відродження полягає в тому, що воно відкрило новий контекст вказаних проблем, їх нове, оригінальне обгрунтування i теоретичне вирішення... Насамперед, Відродження по-новому трактує природу людини, iї призначення і місце в світобудові...» [276]. Людина розглядається як 
SCIENTIFIC APPROACHES IN JURISPRUDENCE

центр світу поряд з Богом, а тому характеризується як боголюдина, з усіма атрибутами: розумом, творчістю, здатністю творити за законами добра і краси. 3 іншого боку, філософія цього часу розглядає людину як індивідуальність неповторне, унікальне, своєрідне втілення людських сил в кожному індивідові. «Ні про одну культуру аж до самого Нового часу, - зазначав один з найвідоміших дослідників західноєвропейського Відродження Л. Баткін, - ну неможливо було б сказати, що вона перебувала в “пошуках індивідуальності”, тобто прагнула відстояти і обгрунтувати незалежну гідність особливої індивідуальної думки, смаку, обдарування, способу життя... Ідея індивідуальності, як це не здається дивним, була невідома усім традиціоналістським суспільством, включаючи греко-римську Античність» [277].

В епоху Відродження по-новому зазвучала тема природних прав, а найбільша заслуга в цьому належала видатному філософу, юристу, політичному мислителю Гуго Гроцію. Його працю «Про право війни і миру. Три книги, в яких пояснюється природне право і право народів, а також принципи публічного права» вважають класичним дослідженням теми природного права.

Так само, як і вся філософія Відродження не змінила коло головних своїх проблем у порівнянні з попередніми епохами, так само Г. Гроцій суттєво не змінив змісту природного права у порівнянні з софістами чи Арістотелем. Аналогічно їм нідерландський мислитель виводив природне право 3 природи людини. Однак його революційна роль полягала в іншому. Він шукав інших ракурсів обгрунтування природного права, інші його докази і в цьому контексті він виразно інший, ніж софісти та Арістотель.

Перша проблема, яку ставив Г. Гроцій - це питання про сутність людини. «Людина, - писав він, - безперечно є твариною, але твариною вищого кшталту, куди більш далекою від інших тварин, ніж різні види тварин різняться між собою... Одначе серед характерних рис людини - потяг до суспільства, тобто до суспільного життя - не до життя взагалі, а до мирного й організованого, відповідно до міри розуму, співжиття з людьми, подібними до себе; такий суспільний потяг стоїки назвали “соціабельністю”» [278]. Як видно, цим 
висловом нідерландський мислитель виділяє дві суттєвих риси людини як істоти. Перша 3 них полягає в природній потребі суспільності людини, іiі колективістському способі існування. Друга підкреслює мирний характер людини в умовах суспільності. Людині не потрібна колективістська форма існування на засадах агресії та війни. Збереження миру і злагоди в суспільстві $\epsilon$ внутрішньою потребою людини. Ось саме в цих сутнісних рисах людської природи Г. Гроцій і вбачав джерело природного права «Таке підтримання соціального ладу, яке ми приблизно окреслили і яке узгоджується з людським розумом, обгрунтовано можна назвати джерелом права. До цієї сфери права належать утримування від того, що належить іншому, повернення іншому будьякої його власності, яка могла опинитися в нас, а також того прибутку, який ми могли одержати від цієї власності; зобов'язання виконувати обіцянки, відшкодовувати втрату з нашої вини і накладати на людей покарання, на які вони заслуговують» [279].

Друга проблема випливає з вищеназваного і для Г. Гроція вона виявляється як питання про пошук таких аргументів на користь природного права, які б не піддавалися жодному сумніву ні при яких умовах. «Я ставив собі за мету, підкреслює мислитель, - шукати для положень природного права докази, які засновані на таких достовірних поняттях, щоб ніхто не міг їх заперечити без насильства над самим собою. Основні ж начала природного права, якщо звернути на них увагу належним чином, ясні та очевидні самі по собі так само, як і те, що ми сприймаємо нашими відчуттями, які не вводять в заблудження, якщо тільки органи відчуттів знаходяться в належному порядку і всі необхідні для них умови є в наявності» [280]. В цьому контексті нідерландський мислитель шукає інші докази природного права, ніж його попередники. Для нього природа людини - абсолютно ясне і чітке джерело природного права. Тут його думка нічим не відрізняється від софістів чи Арістотеля, чи всіх інших дослідників. Г. Гроцій іде далі, він називає соціабельність, суспільність головним і безсумнівним джерелом природного права. Соціальність людини, на його думку, $€$ очевидною і не вимагає доказів хоча б тому, що вона - природний стан людини, 
а значить іï природне право. «Природні права людини, - передають думку Г. Гроція Дж. Себайн та Т. Торсон, - не є результатом добровільного вибору чи продуктом домовленості, а навпаки. Адже сама людська натура, яка, навіть якби нам нічого не бракувало, привела б нас до суспільних взаємин, є матір’ю природного права» [281].

Після того, як Г. Гроцій обгрунтував соціальність людини її найважливішою природою i, таким чином, найглибшим джерелом природного права, він шукає новий аргумент на доказ своєї ідеї. Цей аргумент він знаходить в розумі. Бо для того, щоб довести природне право як очевидне і ясне продовження людської природи, потрібний доказ, який має бути так само очевидним і ясним. I таким доказом, на думку нідерландського вченого, є розум. Він - друга необхідна умова природного права людини. Розумність людини не тільки виступає підставою природного права людини, але й одночасно є тією спонукальною силою, яка змушує людину до реалізації своїх природних прав, хоче цього сама людина чи не хоче. «Закон природи - це диктат здорового розуму, який вказує, що певна дія, відповідно до того, узгоджується вона чи не узгоджується 3 раціональною природною, містить у собі моральну якість першоелементів чи моральну необхідність; і що, як наслідок, таку дію або забороняє, або приписує творець природи - Бог» [282]. А оскільки це саме так, то і методологія дослідження феномена природного права повинна бути адекватною сутності такого права. Звідси - ідея розуму як не тільки базової умови конституювання природного права людини, але й як стрижня наукової методології розкриття сутності природного права.

В цьому місці я означу головну заслугу Г. Гроція у обгрунтуванні природного права, крім того, що показано вище. Нідерландський вчений фактично вперше в історії західноєвропейської політичної думки означив проблему методології як найважливішу у справі обгрунтування природного права людини. Він не пішов шляхом софістів чи Арістотеля, які особливим чином не турбувалися про концептуальність аргументів на користь природного права людини. Г. Гроцій поставив за мету сформулювати таку методологію, яку 
SCIENTIFIC APPROACHES IN JURISPRUDENCE

потім охарактеризують як раціоналістичну. «Величезне значення теорії природного права..., - зазначають Д. Себайн і Т. Торсон у своїй фундаментальній книзі «Історія політичної думки», - пояснюється не тим змістом, який в неї вклав Гроцій, оскільки в цьому відношення він ішов шляхом, второваним стародавніми правниками. Добра віра, реальна справедливість i непорушність угод за всіх часів були правилами, яким приписувалося природне походження. Значення було методологічним. Теорія забезпечувала раціональний метод, який в сімнадцятому столітті міг вважатися науковим... Вона, в головному, зверталася до розуму, як і всі стародавні варіанти природного права, але значення розуму досягло такого ступеня чіткості, якого ніколи не було за античних часів. Істотні часті Гроцієві посилання на математику. Певні положення права аксіоматичні, як аксіоматичне те, що двічі по два - чотири; ці положення гарантовані їхньою ясністю, простотою й само очевидністю... Саме ця якість методу приваблювала Гроція... Він мав намір зробити для права те, що згідно з його розумінням предмета, успішно було здійснено в математиці, або те, що Галілей зробив для фізики» [283]. До цього додам, що як це не дивно звучить, однак, можливо саме Г. Гроція потрібно вважати засновником раціоналістичного методу в науці, а не Р. Декарта. Адже вказана мною основна робота нідерландського вченого з'явилася раніше усіх методологічних праць француза.

Підіб’ю короткі висновки. Перший полягає в надзвичайній актуальності природних прав людини, особливо в наш час, коли права і свободи громадян стали наріжним каменем суспільної практики світової спільноти. Другий вказує на глибоку укоріненість вказаної проблеми в історії західноєвропейської інтелектуалістики. Третій доводить, що в західноєвропейській традиції склалася доволі ясна дослідницька лінія наукових розробок проблеми природного права, вузловими складовими якої стали погляди давньогрецьких софістів, Арістотеля та Г. Гроція. Давньогрецькі софісти актуалізували проблему природного права, Арістотель вніс в ії̈ зміст суттєві зміни, які стосувалися сталих чи змінних вимірів природного права. Г. Гроцій збагатив методологічний арсенал досліджень цієї проблеми. Можна говорити про те, що на нідерландському мислителі певним 
SCIENTIFIC APPROACHES IN JURISPRUDENCE

чином завершився етап становлення природного права людини як теоретичної проблеми. Одночасно концепція Г. Гроція про природні права людини відкривала новий період досліджень проблеми, який розгорнеться в сучасні концепції природного права, а також у міжнародні документи про права i свободи людини і громадянина, притаманні нашому часу. 


\section{REFERENCES}

1. Логвиненко М., Кордунян I. Комунікаційні та професійні навички медіатора - запорука ефективного вирішення конфлікту. Реформування правової системи в контексті євроінтеграційних процесів: матеріали IV Міжнар. наук.практ. конф., 21-22 травня 2020 р. Суми: Сумський державний університет, 2020. Ч. 2. C. $169-172$.

2. Thomas Repicky. How to Talk and Listen Effectively in Mediation. Mediate.com: website. URL: https://www.mediate.com/articles/RepickyT1.cfm.

3. John Ford. Key Communication Skills for the Mediator. Resoblog - resologics: website. URL: https://www.resologics.com/resologics-blog/2016/7/26/keycommunication-skills.

4. Kylie Millbern. Mediator Skills. The Mediation Group: website. URL: https://www.themediationgroup.org/news/mediator-skills.

5. Sam Imperati. Traits of a 'Mediator'. Mediate.com: website. URL: https://www.mediate.com/articles/imperati1.cfm.

6. Про загальні засади створення і функціонування спеціальних (вільних) економічних зон: Закон України від 13.10.1992 зі змінами. URL: https://zakon.rada.gov.ua/laws/main/2673-12

7. Сіваченко І.Ю., Кухарська Н.О., Левицький М.А. Вільні економічні зони: навчальний посібник. К.: Дакор;Алерта., 2001. 480 с.

8. Naomi Davies. fDI's Global Free Zones of the Year 2019. fDIntelligence. October 14, 2019. URL: https://www.fdiintelligence.com/article/75879

9. Бек Ю.Б. Правове регулювання іноземних інвестицій у спеціальних (вільних) економічних зонах України (на матеріалах СЕЗ «Яворів»). Автореферат дисертації канд. юрид. наук 12.00.03..... Одеса. 2005. 22c. URL: http://hdl.handle.net/11300/1080

10. Про індустріальні парки: Закон України від 4.07.2013 року. URL: http://search.ligazakon.ua/l_doc2.nsf/link1/T125018.html

11. Про затвердження форми Типового договору про створення та функціонування індустріального парку: Наказ Міністерства економічного 
SCIENTIFIC APPROACHES IN JURISPRUDENCE

розвитку i торгівлі України від 15.04.2013 № 386. URL: http://search.ligazakon.ua/1_doc2.nsf/link1/RE23265.html

12. Про заходи щодо створення та функціонування спеціальних (вільних) економічних зон і територій із спеціальним режимом інвестиційної діяльності: Постанова Кабінету Міністрів України від 24 вересня 1999 р. №1756. URL: https://zakon.rada.gov.ua/laws/show/1756-99-\%D0\%BF\#Text

13. Длігач А. Інтеграційне середовище України. одно- та багатовекторність інтеграційного розвитку. URL: http://pandia.ru/text/78/168/3404.php

14. Шевченко Н.Л. Адміністративно-правове забезпечення дотримання прав людини в правоохоронних органах України: дис. к-та юрид. наук: 12.00.07. Київ. 2018. $231 \mathrm{c}$.

15. Угода про асоціацію між Україною та Європейським Союзом. Урядовий портал. URL: http://www.kmu.gov.ua/control/publish/article?art id=248387631

16. Братель С.Г. Шляхи реформування правоохоронної системи України. Роль правоохоронних органів у формуванні правової держави в умовах євроінтеграції України. Національна академія внутрішніх справ. Київ. 2015.С. $54-56$

17. Конституція України: Закон України від 28.06.1996 № 254к/96-В. Відомості Верховної Ради України. 1996. № 30. Ст. 141.

18. Захаров Є. Реформування органів внутрішніх справ та права людини URI . http://khpg.org/index.php?id=1488907079.

19. Билінська О. Б. Функції системи гарантування вкладів / О.Б. Билінська // Науковий вісник Ужгородського національного університету. - 2017. — Ч. 1. — Вип. 12. - С. 38-42.

20. Банки, що ліквідуються [Електронний ресурс] / Фонд гарантування вкладів фізичних осіб. - Режим доступу : http://www.fg.gov.ua/notpaying/liquidation (дата звернення 21.08.2018).

21. Бухтіарова А. Г. Розвиток національної системи страхування вкладів : дис. ... канд. екон. наук : 08.00.08 / А. Г. Бухтіарова. - Суми, 2015. - 284 с. 
SCIENTIFIC APPROACHES IN JURISPRUDENCE

22. Огієнко В. І. Система гарантування депозитів фізичних осіб в Україні : автореф. дис. ... канд. екон. наук : спец. 08.04.01 / В. І. Огієнко. - Львів, 2005. - C. 18 .

23. Коваленко В. В. Розвиток систем гарантування вкладів до і після кризи В. В. Коваленко // Вісник соціальноекономічних досліджень. - 2013. — № 1. C. $363-370$.

24. Про систему гарантування вкладів фізичних осіб : Закон України від 23.02.2012 № 4452-VI [Електронний ресурс]. - Режим доступу : http://zakon5.rada.gov.ua/laws/show/4452-17 (дата звернення 21.08.2018).

25. Безвух С. В. Функціонування системи гарантування вкладів фізичних осіб в Україні / С. В. Безвух // Глобальні та національні проблеми економіки. 2015. - Вип. 3. - С. 675-680.

26. Скірка А. С. Проблематика фінансової діяльності Фонду гарантування вкладів фізичних осіб / А. С. Скірка, Б. П. Адамик // Глобальні та національні проблеми економіки. - 2017. - Вип. 19. - С. 462- 468.

27. Про затвердження Положення про порядок розрахунку, нарахування $\mathrm{i}$ сплати зборів до Фонду гарантування вкладів фізичних осіб : Рішення Виконавчої дирекції Фонду гарантування вкладів фізичних осіб від 02.07.2012 № 1 [Електронний pecypc]. http://zakon3.rada.gov.ua/laws/show/z1273-12.

28. Ходак Є. С. Особливості формування коштів Фонду гарантування вкладів фізичних осіб / Є. С. Ходак // Часопис Академії адвокатури України. 2015. - № 4. - T. 8. - С. 126-130.

29. Башлай С. В. Інструменти банківського нагляду на консолідованій основі [Електронний ресурс] / С. В. Башлай // Фінансовий простір. — 2011. — № 3

C. $\quad 54-59$.

Режим доступу https://fp.cibs.ubs.edu.ua/FILES/1103/11bsvbst.pdf (дата звернення 21.08.2018).

30. Про банки і банківську діяльність : Закон України від 07.12.2000 № 2121III. [Електронний ресурс] // Відомості Верховної Ради України. - 2001. — № 5-6. - Режим доступу : http://zakon5.rada.gov.ua/laws/show/2121-14 . 
SCIENTIFIC APPROACHES IN JURISPRUDENCE

31. Господарський кодекс України : Закон України від 16.01.2003№ 436-IV [Електронний ресурс] // Відомості Верховної Ради України. - 2003. — № 18, 19-20, 21-22. — Режим доступу : http://zakon.rada.gov.ua/laws/show/436-15 .

32. Подцерковний О. П. Господарське право : підручник / О. П. Подцерковний. — Харків : Одіссей, 2010. - 640 с.

33. Рябченко О. П. Сутність адміністративно-господарських санкцій / О. П. Рябченко // Вісник Верховного Суду України. — 2009. — № 2. - С. 37-40.

34. Кантор Н. Ю. Адміністративно-господарські санкції як гарантії реалізації та захисту економічних інтересів держави / Н. Ю. Кантор // Науковий вісник Ужгородського Національного університету. - Ужгород : Видавничий дім «Гельветика», 2015. — Т. 2. — № 34. - С. 87-90. — (Серія : право).

35. Іванський А. Й. Фінансово-правова відповідальність: теоретичний аналіз : монографія / А. Й. Іванський. — Одеса : Юридична література, 2008. - 501 с.

36. Про затвердження Положення про Міністерство фінансів України : постанова Кабінету Міністрів України від 20.08.2014 № 375 [Електронний pecypc]. - Режим доступу : http://zakon5.rada.gov.ua/laws/show/375-2014\%D0\%BF (дата звернення: 05.09.2017).

37. Угода про торговельні аспекти прав інтелектуальної власності (Угода ТРІПС) від 15 квітня 1994 р. / Міжнародний документ. Офіиійний вісник Украӥни. 2010. № 84. Ст. 2989. URL: http://zakon4.rada.gov.ua/laws/show/981_018

38. Угода про асоціацію між Україною, з однієї сторони, та Європейським Союзом, Свропейським Співтовариством з атомної енергії і їхніми державамичленами, з іншої сторони: ратифікована 16 вересня 2014 року Верховною Радою України та Європейський парламентом / Міжнародний документ. Офіщіийний вісник Украӥни. 2014. № 75, Т 1. Ст. 2125. URL: http://zakon5.rada.gov.ua/laws/show/984_011

39. Законодательство СССР по изобретательству / под ред. А. И. Дорина. Москва: ВНИИПИ, 1979. С. 16-23.

40. Цивільний кодекс Української РСР: Закон Української РСР від 18 липня 1963 р. / Відомості Верховної Ради Української РСР. 1963. № 30. Ст. 463. 
Офіційний текст зі змінами і доповненнями. Право Украӥни. 1993. № 11-12. Ст. 472.

41. Тимчасове положення про правову охорону об’єктів промислової власності та раціоналізаторських пропозицій: Указ Президента України від 18 вересня 1992 р. № 479/92. URL: http://zakon5.rada.gov.ua/laws/show/479/92/page

42. Про охорону прав на промислові зразки: Закон України від 15 грудня 1993 р.: зб. нормат. актів з питань промислової власності. Київ: Вища школа, 1998. C. 49-65.

43. Про охорону прав на знаки для товарів і послуг: Закон України від 15 грудня 1993 р.: зб. нормат. актів з питань промислової власності. Київ: Вища школа, 1998. С. 66-79.

44. Про охорону прав на винаходи і корисні моделі: Закон України від 15 січня 1993 р.: зб. нормат. актів з питань промислової власності. Київ: Вища школа, 1998. С. 27-47.

45. Конституція України: Закон України від 28 червня 1996 р. № 254к/96-ВР / Верховна Рада України. Відомості Верховної Ради України. 1996. № 30. Ст. 141.

46. Про охорону прав на винаходи і корисні моделі: Закон України від 1 червня 2000p. №1771-III із змінами і доповненнями, внесеними Законом України від 21 грудня 2000 р. № 2188-III / Верховна Рада України. Відомості Верховної Ради Украӥни. 2001. № 8. Ст. 37.

47. Шишка Р. Б. Інтелектуальна власність: охорона і захист. Конституц̧ія України -основа модернізації державного суспільства. Харків, 2001. С. 455-457.

48. Крижна В. М. Реалізація конституційного права на результати інтелектуальної діяльності. Конституц̧ія України - основа модернізації державного суспільства. Харків, 2001. С. 493-495.

49. Цивільний кодекс України: Кодекс України від 16.01.2003 р. № 435-IV. URL: http://zakon5.rada.gov.ua/laws/show/435-15

50. Підопригора О. А. Загальні положення про право інтелектуальної власності у Цивільному кодексі України. Право України. 2003. № 7. С. 97-101. 
SCIENTIFIC APPROACHES IN JURISPRUDENCE

51. Кузнєцова Н. С. Стан і тенденції розвитку цивілістичної науки в Україні. Право України. 2014. № 6. С. 9-14.

52. Скрипко В. Р. Охрана прав изобретателей и рационализаторов. Москва: Наука, 1982. 80 c.

53. Про внесення змін до деяких законодавчих актів України щодо посилення охорони і захисту прав на торговельні марки і промислові зразки та боротьби з патентними зловживаннями: Закон України від 21 липня 2020 р. № 815 - IX. URL: https://zakon.rada.gov.ua/laws/show/815-20\#Text

54. Ульянова Г. О. Реалізація права інтелектуальної власності на промисловий зразок. Міжнародний юридичний вісник: зб. наук. праць / Національний університет державної податкової служби України. 2015. № 1 (2). C. 189-194.

55. Конституція України від 28 червня 1996 р. Відомості Верховної Ради України. 1996. № 30. Ст. 141.

56. Кримінальний кодекс України від 5 квітня 2001 р. Biдомості Верховної Ради України. 2016. № 25-26. Ст. 131.

57. Джужа О. М., Орлов Ю. Ю. Аналіз загальнодержавних комплексних заходів запобігання злочинності в Україні. Науковий вісник КНУВС. 2006. № 3. C.119-129.

58. Заросинський Ю., Рощина I. Запобігання злочинам: деякі питання теорії і практики. Право України. 2003. №10. С.78-81.

59. Зеленецкий В. С. Общая теория борьбы с преступностью. Харьков : Основа, 1994. $321 \mathrm{c.}$

60. Литвак О. М. Державний вплив на злочинність. Кримінологічноправове дослідження. К. : Юрінком Інтер, 2000. 278 с.

61. Дэвис Н. История Европы; пер. с англ. Т. Б. Менской. М.: АСТ; Транзиткнига, 2005. 943 с.

62. Захват посольства США в Тегеране 4 ноября 1979 года [Електронний pecypc]. - Режим доступу : http://ria.ru/world/20091104/191810271.htm. 
63. Науково-практичний коментар Кримінального кодексу України/за ред. М. І. Мельника, М. І. Хавронюка. 10-те вид., переробл. та доповн. Київ: ВД «Дакор», 2018. 1368 c.

64. Кримінальне право України: Особлива частина: підручник/В. Я. Тацій, В. І. Тютюгін, В. І. Борисов та ін.; за ред. В. Я. Тація, В. І. Тютюгіна, В. І. Борисова. - 6-те вид., перероб і допов. Харків: Право, 2020. 768 с.

65. Науково-практичний коментар до Кримінального кодексу України : у 2 т. - 3-те вид., перероб. та доп. К.: Алерта; КНТ; Центр учбової літератури, 2009. - Т. 2 / за заг ред. П. П. Андрушка, В. Г. Гончаренка, С. В. Фесенка. 624 с.

66. Лупу А. А. Международное уголовное право: учеб. пос. / А. А. Лупу, И. Ю. Оськина. М.: Изд.-торг. корп. «Дашков и К», 2012. 312 с.

67. Мохончук С. М. Злочини проти миру та безпеки людства: генезис, еволюція, сучасна регламентація у кримінальному праві і законі: монографія. Х.: Право, 2013. 528 с.

68. Житний О. О., Ральченко І. М. Кримінальна відповідальність за злочини проти осіб та установ, що мають міжнародний захист (національно-правовий вимір): монографія. Х.: ТОВ «В деле», 2017. 256 с.

69. Правові позиції Верховного Суду України та Вищого спеціалізованого суду України з розгляду цивільних і кримінальних справ щодо застосування законодавства у справах кримінальної юрисдикції / упоряд. Н. О. Гуторова, О. О. Житний. Х.: Одіссей, 2013. 448 с.

70. Храмцов О. М. Кримінально-правове та кримінологічне забезпечення охорони особи від насильства: монографія. Х.: НікаНова, 2015. 471 с.

71. Кудрявцев В. Н. Объективная сторона преступления. М.: Госюриздат, 1960. $243 \mathrm{c}$.

72. Гринберг М. С. Преступления против общественной безопасности: учеб. пособие. Свердловськ: Свердл. юрид. ин-т, 1974. 177 с.

73.Каба О.В. Механізм європейської системи захисту прав людини. URL : http://dspace.nlu.edu.ua/bitstream/123456789/11866/1/Kaba.pdf 
74. Основи права Європейського Союзу: нормативні матеріали / М. В. Буроменський, Т. М. Анакіна, Т. В. Комарова та ін..; за заг. ред. М. В. Буроменського Х. : Право, 2015. 328 с.

75. Комарова Т.В. Практика Суду Свропейського Союзу щодо приєднання ЄC до Конвенції про захист прав людини і основоположних свобод. URL : http://dspace.nlu.edu.ua/bitstream/123456789/9793/1/Komarova.pdf

76. Добрянський С. Хартія основних прав Європейського Союзу як регіональний праволюдинний стандарт. Вісник Наџіональної академії правових наук Украӥни. 2013. № 3 (74). С. 23-30.

77. Энтин К. В. Присоединение Евросоюза к ЕКПЧ. Европейское право. 2012. № 3. C. 111-123

78. Яковюк I. Права людини в Свропейському Союзі: загальнотеоретичний аналіз C. 55-63. URL http://dspace.nlu.edu.ua/bitstream/123456789/5598/1/Jakovyk_55.pdf

79. Коваленко Я. ЄС на захисті прав людини. Юридична газета. 2018. №36. URL : https://yur-gazeta.com/publications/practice/inshe/es-na-zahisti-pravlyudini.html

80. Коваленко Я.І. Аналіз діяльності органів Європейського Союзу, до компетенції яких входить захист прав людини. Вісник пенітенціарної асоиіації України. 2018 № 1(3). С. 184-190. URL : https://visnykpau.com/index.php/journal/article/download/142/98/

81. Європейський омбудсмен: матеріал голосарію термінів $\mathrm{EC}$. URL :http://europa.dovidka.com.ua/ee.html

82. Консолідована версія Договору про функціонування Європейського Союзу. URL : https://zakon.rada.gov.ua/laws/show/994_b06\#Text

83. Шишка Р. Б. Инвестиционное право Украины: учеб. пособие / Р. Б. Шишка. - Х.: Эспада, 2000. - 176 с.

84. Гущин В. В. Инвестиционное право: учебник / В. В. Гущин, А. А. Овчинников. - Изд. 2-е, перераб. и доп. - М.: Эксмо, 2009. - 623 с. 
85. Фархутдинов И. З. Инвестиционное право: учеб.-практ. пособие / И. 3. Фархутдинов, В. А. Трапезников. - М.: Волтерс Клувер, 2006. - 412 с.

86. Лук'яненко Д. Г. Міжнародна інвестиційна діяльність: підручник / Д. Г. Лук'яненко, Б. В. Губський, О. М. Мозговий та ін.; за ред. д.ю.н., проф. Д. Г. Лук'яненка. - К.: КНЕУ, 2003. - 387 с.

87. Міжнародне торгове право: навч. посіб. / О. В. Київець, В. О. Голубєва. - К.: КНЕУ, 2010. -450 с.

88. Податковий кодекс України від 02.12.2010 р. // Відомості Верховної Ради України. - 2011. - № 13-17, Ст.112.

89. ЗаконУкраїни «Про інвестиційну діяльність» від 18.09.1991 р. № 1560-XII // Відомості Верховної Ради України. - 1991.- № 47. - Ст. 646.

90. Закон України «Про угоди про розподіл продукції» від 14.09.1999 р. № 1039-XIV // Відомості Верховної Ради України. - 1999. - № 44. - Ст.391.

91. Закон України «Про міжнародні договори України» від 29.06.2004 р. № 1906-IV // Офіційний вісник України. - 2004. - № 35. - Ст. 2317.

92. Закон України «Про режим іноземного інвестування» від 19.03.1996 p. № 93/96-ВР // Відомості Верховної Ради України. - 1996. - № 19 . - Ст. 80.

93. On Amendments to the Constitution of Ukraine (on the Decentralization of Power): draft Law of Ukraine No. 2217a dd. 1 July 2015 / bill initiated by P. O. Poroshenko. Verkhovna Rada of Ukraine: official website.

94. Constitution of Ukraine: official publication / Verkhovna Rada of Ukraine. Kyiv: Parliamentary publishing house, 2017. 68 pages.

95. On Local Self-Government in Ukraine: Law of Ukraine No. 280/97-BP dd. 21 May 1997. Information of the Verkhovna Rada of Ukraine. 1997. No. 24. Page 170. Update date: 23.07.2020. URL: http://zakon4.rada.gov.ua/laws/show/280/97-вр (visit date: 10.11.2020).

96. D. D. Zaiats. Statutory Regulation of the Local Self-Government System in Ukraine: abstract of a thesis ... of the candidate of sciences for public management: 25.00.04 / Class. priv. univ. Zaporizhzhia, 2010. 20 pages. 
97. On Laws and Regulations: draft Law of Ukraine No. 7409 dd. 1 December 2010 / bill initiated by Yu. R. Miroshnichenko. Verkhovna Rada of Ukraine: official website. URL: http://w1.c1.rada.gov.ua/pls/zweb2/webproc4_1?pf3511=39123 (visit date: 10.11.2020).

98. O. V. Slobozhan. Improvement of the Regulatory and Legal Support of the Activities of Legal Services of Local Self-Governing Authorities. Public Management: Improvement and Development. 2012. No.4. URL: http://www.dy.nayka.com.ua/?op=1\&z=426 (visit date: 10.11 .2020 ).

99. On Additional Measures for Ensuring Transparency in the Activities of Public Authorities: Decree of the President of Ukraine No. 683/2002 dd. 1 August 2002. Official Gazette of Ukraine. 2002. No. 31. Page 1463.

100. On the Basic Principles of the Information Society Development in Ukraine for 2007-2015: Law of Ukraine No. 537-V dd. 9 January 2007. Official Gazette of Ukraine. 2007. No. 8. Page 273.

101. On the Approval of the Information Society Development in Ukraine: Order of the Cabinet of Ministers of Ukraine No. 386-p dd. 15 May 2013. Official Gazette of Ukraine. 2013. No. 44. Page 1581.

102. On the National Informatization Program: Law of Ukraine No. 74/98-BP dd. 4 February 1998. Information of the Verkhovna Rada of Ukraine. 1998. No. 27 28. Page 181. Update date: 01.08.2016. URL: http://zakon4.rada.gov.ua/ laws/show/74/98 (visit date: 10.11 .2020 ).

103. S. D. Titov, O. V. Titova. Websites of Local Self-Governing Authorities as a Component of the Introduction of e-Government in Ukraine. Gazette of the Kharkiv State Academy of Culture. 2013. Iss. 39. Pages 144-153.

104. O. A. Savchenko. State Registration of Laws and Regulations as a Mean to Protect Individuals' Rights, Freedoms and Legitimate Interests. Ministry of Justice of Ukraine: off. website. URL: http://old.minjust.gov.ua/8359 (visit date: 10.11.2020).

105. Антонова C.С., Мартинюк Г.Ф. Інформаційна безпека. Державне управління: удосконалення та розвиток. 2019. №11. - URL: $\mathrm{http}: / /$ www.dy.nayka.com.ua/?op=1\&z=1528 
SCIENTIFIC APPROACHES IN JURISPRUDENCE

106. Почепцов Г.Г. Информационные войны. М., Рефл-бук; К., Ваклер, 2000. 576 c. URL: https://itlife.club/books/265064/read

107. Сопілко І.М. Становлення інформаційного суспільства та інформаційні загрози в мережі Інтернет. Юридичний вісник. Повітряне і космічне право. 2017. № 3. C. 61-69.

108. Гуцу С.Ф. Правове регулювання мережі Інтернет: міжнародний i вітчизняний досвід. Вісник НТУУ «КПІ». Політологія. Соиіологія. Право. 2018. Вип. 2 (38). С. 114-118.

109. Кубявка М.Б. Моделі та методи управління інформаційним супроводженням в умовах гібридної війни. Дис... канд. техн. наук. Спец. 05.13 .06 «Інформаційні технології». К., 2017. 199 с.

110. Турченко Ю.В. Засоби масової комунікації як суб’єкт реалізації державної інформаційної політики України в сфері оборони: політико-правове регулювання. Збірник наукових пращь Військового інституту Кийвського національного університету імені Тараса Шевченка. 2013. Вип. 43. С. 113-119.

111. Богданович В.Ю., Ворович Б.О., Марко С.І. Інформаційна безпека як основа воєнної безпеки держави та суспільства. Збірник наукових праџь Центру воєнно-стратегічних досліджень Наџіонального університету оборони України імені Івана Черняховського. 2018. № 3. С. 44-48.

112. Левченко О.В. Класифікація інформаційної зброї за засобами ведення інформаційної боротьби. Сучасні інформаційні технології у сфері безпеки та оборони. 2014. № 2 (20). С. 142-146.

113. Гриняев С. Концепция ведения информационной войны в некоторых странах мира. Зарубежное военное обозрение. 2002. № 2. C. 11-15. URL: http://pentagonus.ru/publ/22-1-0-196

114. Горбань Ю.О. Інформаційна війна проти України та засоби її ведення. Вісник НАДУ. 2015. № 1. С. 136-141.

115. Abdol Hossein Joodaki. The Ubiquitous Effect of Television and Dominant Surveillance in Ray Bradbury's Fahrenheit 451. Rupkatha Journal on Interdisciplinary Studies in Humanities. Volume VII, Number 3, 2015 General Issue, p. 223-230. 
SCIENTIFIC APPROACHES IN JURISPRUDENCE

116. Верголяс О.О. Спеціальні інформачійні операції в системі засобів протидії загрозам наџіональній безпеці Украйни. Міжнародний науковий журнал «Інтернаука». Серія: «Юридичні науки». 2019. № 4.

117. Маркова М.В. Інформаційно-психологічна війна: медико-психологічні наслідки та стратегії протидії. Проблеми безперервної медичної освіти та науки. 2016. № 4. C. 6-10.

118. Мітенко О.В. Інформаційна безпека як складова національної безпеки України. Інформаиійна безпека людини, суспільства, держави. 2019. № 1. С. 27 36.

119. Голуб О. Сайти соцмереж як джерело інформації. 24.02.2016. - URL: https://ms.detector.media/sotsmerezhi/post/16123/2016-02-24-saiti-sotsmerezh-yakdzherelo-informatsii/

120. Міхєєв Ю.І., Чернявський Г.П., Турченко Ю.В., Пінчук О.І. Дефініції поняття «гібридна війна». Збірник наукових пращъь Військового інституту Київського національного університету імені Тараса Шевченка. 2016. Вип. 51. C. 124-130.

121. Международное экономическое право: учеб. пособие / кол. авт.; под ред. А. Н. Вылегжанина. Москва: КНОРУС, 2012. 272 с.

122. Бліхар М. М. Міжнародно-економічне право: навч. посібн. Львів: Лігапрес, 2014. $480 \mathrm{c}$.

123. Бліхар М. М. Міжнародно-правові засади економічної інтеграції держав. Правові засади європейської та євроатлантичної інтеграчії Украӥни: досягнення та перспективи: матер. учасників II Наук.-практ. конф. (м. Львів, 23 листопада 2018 р.). 2018. С. 12-16.

124. Бліхар М. М. Правові форми регіональної інтеграції з глобальним рівнем регулювання міжнародних економічних відносин. Правові засади європейської та євроатлантичної інтеграції України: досягнення та перспективи: матер. учасників III Всеукр. наук.-практ. конф. (м. Львів, 22 листопада 2019 р.). 2019. С. 35-39. 
SCIENTIFIC APPROACHES IN JURISPRUDENCE

125. Богуславский М. М. Международное экономическое право. Москва: Междунар. отношения, 1986. 304 с.

126. Бондаренко Н. О. Дотримання принципу законності як необхідна передумова реалізації Україною інтеграції у Свропейський простір. Україна у світовому економічному просторі: иляхи подолання кризи (економіка, фінанси та право): зб. матер. IX Міжнар. наук.-практ. конф. (м. Київ, 27 березня 2009 р.). 2009. $306 \mathrm{c}$.

127. Боярська 3. І. Міжнародне комерційне право: навч. посібн. Київ: КНЕУ, 2001. $144 \mathrm{c}$.

128. Шумилов В. М. Международное экономическое право: учебн. Москва: Юрайт, 2011. 612 с.

129. Аксенова Е. Технологические аспекты проведения аттестации / Е. Аксенова // Управление персоналом. - 1999. - № 2. - С. 22-28.

130. Борисова Е. Аттестация. Стоит ли игра свеч? / Е. Борисова // Справочник кадровика. - 2003. - № 2. - С. 79-81

131. Горбунова И.Г. От оценки рабочих мест - к аттестации персонала / И.Г. Горбунова, Н.П. Леонова // Управление персоналом. — 2005. — № 23. C. 41-45.

132. Иванов Ю.В. Аттестация персонала / Ю.В. Иванов // Управление персоналом. - 2006. — № 6. - С. 60-72.

133. Кодекс законов о труде Украины. - Х.: Одиссей, 2007. - 159 с.

134. Про вищу освіту: Закон України від 17.01.2002 р. № 2984-III (в ред. від 10.02.2010 р.) // Верховна Рада України [Офіційний веб-сайт] / Законодавство України [Сайт]. — Режим доступу: http://zakon.rada.gov.ua/cgibin/laws/main.cgi?nreg=2984-14.

135. Про наукову i науково-технічну діяльність: Закон України від 13.12.1991 №1977-XII (в ред. від 06.01.2011 р.) // Верховна Рада України [Офіційний веб-сайт] / Законодавство України [Сайт]. - Режим доступу: http://zakon1.rada.gov.ua/cgi-bin/laws/main.cgi?nreg=1977-12. 
136. Про затвердження Положення про атестацію наукових працівників: положення, затв. Постановою Кабінет Міністрів України від 13.08.1999 р. №1475 (в ред. від 13.08.1999 р.) // Верховна Рада України [Офіційний веб-сайт] / Законодавство України [Сайт]. — Режим доступу: http://zakon1.rada.gov.ua/cgibin/laws/main.cgi?nreg=1475-99-\%EF.

137. Ponomarenko O.V. Theoretical and methodological aspects of higher education management: theory and practice / O.B. Ponomarenko II Science. Visn. Melitopol state. ped un-tu them. B. Khmelnytsky. Series "Pedagogy". 2011. № 7, pp. 346-349. [Electronic resource]. Access mode: http://lib.mdpu.org.ua/nvsp/ BAK7 / 7 / 53.pdf.

138. Gonchar M.F. Management decisions in the enterprise management system: author's ref. days. ... cand. econ. Science: special. 08.00.04 "Economics and management of enterprises (by type of economic activity)" / M.F. Potter. Lviv, 2011. $25 \mathrm{p}$.

139. Bandurka O.M. Theory and practice of management of internal affairs bodies of Ukraine: [monograph] / O.M. Bandurka. X.: HУBC, 2004. 780 p.

140. Shelomovska O. Kontseputalni osnovy formuvannya upravlinskykh rishen u derzhavnomu upravlinni vyschoi osvitoi / Kontseputalni osnovy formuvannia upravlinskykh rishen u derzhavnomu upravlinni vyschoi osvitoi [Conceptual bases of formation of management decisions in public administration of higher education]. 2010. Vip. № 2 (5). 10 s. [Electronic resource]. Access mode: http://www.dridu.dp.ua/vidavnictvo/2010/2010_02(5)/10somsep.pdf.

141. Konoplyov V.V. Questions of structuring the procedure of preparation of management decisions in the administrative activity of internal affairs bodies / V.V. Konoplyov // Bulletin of the KhNUVS. 2007. Vip. 38. 6 p. [Electronic resource]. Access mode: http: // visnyk.univd.edu.ua/?action=publications\&pub_name $=$ visnik\&pub_id $=201088 \&$ $\operatorname{mid}=8 \&$ year $=2007 \&$ pub_article $=208522$. 
142. Guberska N.L. Procedures for making and implementing management decisions in higher education // Scientific Bulletin of the International Humanities University. Ser .: Jurisprudence. 2014. № 10-2. volume 1. p. 66.

143. Viktorov V.G. Management of the quality of education (socio-philosophical analysis): [monograph] / V.G. Viktorov. D.: Porogi, 2005. 286 p.

144. Melnik RS, Bevzenko VM General administrative law: Textbook / For general. ed. R.S. Miller. K .: Vaite, 2014. 376 p.

145. Recommendation № R (87) 16 of the Committee of Ministers of the Council of Europe to member states on administrative procedures affecting the rights of a large number of persons, adopted on 17 September 1987 at the 410th meeting of the Ministers' Deputies [Electronic resource]. Access mode: http://lib.podelise.ru/ docs / $1398 /$ index-1531.html? Page $=43$.

146. Paterilo I. Procedural requirements for administrative acts under the laws of the European Union // National Legal Journal: Theory and Practice. 2015. p. 54-55.

147. Timoshchuk V.P. Administrative acts: procedure for adoption and termination: Monograph. K .: "Konus-Yu", 2010. 296 p.

148. Bill on regulations of November 30, 2010 - [Electronic resource]. Access mode: http://w1.c1.rada.gov.ua/pls/zweb2/webproc4_1?pf3511=39123.

149. Conclusion of the Main Scientific and Expert Department on the draft Law of Ukraine "On normative legal acts" (registered № 7409 of 01.12.2010) // [Electronic resource]. Access mode: http: //w1.c1.rada.gov.ua/pls/zweb2/webproc4_1? Pf3511= 39123

150. Khomenko V.O. Procedure for adoption of legal acts by local governments // Scientific Bulletin of Uzhhorod National University. RIGHT series. Issue 34. Volume 2. 2015. p. 145-146.

151. Bytyak Y., Yakovyuk I., Tragniuk O., Komarova T., Shestopal S. (2017). The state sovereignty and sovereign rights: The correlation problem. Man in India, 97(23), 577-588. URL: 
SCIENTIFIC APPROACHES IN JURISPRUDENCE

http://dspace.nlu.edu.ua/bitstream/123456789/13482/1/Bytyak_Yakovyuk_Tragniuk

Komarova_Shestopal_577-588.pdf [accessed 19 October 2020] [in Eng.]

152. Яковюк I. (2003). Історичні передумови і основні етапи європейської інтеграції. Вісник Академії правових наук України, 4, 82-92. [in Ukr.]

153. Menzel A. (2020). The pressures of getting it right: Expertise and victims' voices in the work of the Sierra Leone Truth and Reconciliation Commission (TRC). International Journal of Transitional Justice, Oxford University Press (OUP). DOI: https://doi.org/10.1093/ijtj/ijaa011.

URL:https://academic.oup.com/journals/pages/open_access/funder_policies/chorus/st andard_publication_model [accessed 19 October 2020]. [in Eng.]

154. Human Rights Watch, Genocide, War Crimes and Crimes Against Humanity: A Digest of the Case Law of the International Criminal Tribunal for Rwanda, 15 January 2010. URL: https://www.refworld.org/docid/4b5438802.html [accessed 19 October 2020] [in Eng.]

155. Carolan G. (2020). Transition Without Transformation: The Legacy of Sudan's Comprehensive Peace Agreementю International Journal of Transitional Justice, Oxford University Press (OUP). URL:

https://academic.oup.com/journals/pages/open_access/funder_policies/chorus/standard_publication_model. [accessed 19 October 2020]. DOI: https://doi.org/-10.1093/ijtj/ijaa010 [in Eng.]

156. Beresford A., Wand D. (2020). Understanding bricolage in norm development: South Africa, the International Criminal Court, and the contested politics of transitional justice. Review of International Studies, Cambridge University Press (CUP), 1-21. DOI: https://doi.org/10.1017/s0260210520000224 [in Eng.]

157. Sokolić I. (2016). Researching norms, narratives, and transitional justice: focus group methodology in post-conflict Croatia. Cambridge University Press (CUP). Nationalities Papers. Volume 6, 932-949. URL: https://www.cambridge.org/core/journals/nationalities-papers/article/researchingnorms-narratives-and-transitional-justice-focus-group-methodology-in-postconflict- 
croatia/49C54295C7C41E14E24F9E7D13C9A3BF [accessed 19 October 2020] DOI: https://doi.org/10.1080/00905992.2016.1183605 [in Eng.]

158. Cvikic S. (2019). Deconstruction of 'scientifically based injustices': About post-war traumatized populations of 'spoilers' in Croatia. National Library of Serbia. Sociologija Volume 61, Issue Suppl. 1, 697-717. URL: http://www.doiserbia.nb.rs/Article.aspx?ID=0038-031819697C\#.X41EStAzY2x [accessed 19 October 2020]. DOI: https://doi.org/10.2298/SOC19S1697C [in Eng.]

159. Clark J.-N. (2020). Storytelling, resilience and transitional justice: Reversing narrative social bulimia. Theoretical Criminology, SAGE Publications. URL: https://journals.sagepub.com/doi/10.1177/1362480620933230 [accessed 19 October 2020]. DOI: https://doi.org/10.1177/-1362480620933230 [in Eng.]

160. Clark J. N. (2020). Body Memories as a Neglected Legacy of Human Rights Abuses: Exploring Their Significance for Transitional Justice. SAGE Publications. Social \& Legal Studies. URL: https://journals.sagepub.com/doi/10.1177/0964663920962556 $\quad$ [accessed 19 October 2020]. DOI: https://doi.org/10.1177/0964663920962556 [in Eng.]

161. Jazairi R. (2015). Transitional Justice in Syria: The Role and Contribution of Syrian Refugees and Displaced Persons. Middle East Law and Governance. Brill. Vol. 7, issue 3, 336-359. DOI: https://doi.org/10.1163/18763375-00703002 [in Eng.]

162. Червякова О.В. (2020). Відповідальність за воєнні злочини: через перехідне правосуддя до сталого миру та безпеки України. Проблеми законності. Вип. 150, 161-172. URL: http://plaw.nlu.edu.ua/article/view/208602/213553 [accessed 19 October 2020]. DOI: https://doi.org/10.21564/2414-990x.150.208602 [in Ukr.]

163. Червякова О. В. (2020). Відповідальність за воєнні злочини: механізми та процеси відновлення суверенітету та безпеки України. Форум Права, 61(2). 150-162. URL: http://forumprava.pp.ua/2020-n-2.html [accessed 19 October 2020].DOI: http://doi.org/10.5281/zenodo.3883835 [in Ukr.].

164. The rule of law and transitional justice in conflict and post-conflict societies: Report of the Secretary-General (Distr.: General, 23 August 2004, 
SCIENTIFIC APPROACHES IN JURISPRUDENCE

S/2004/616). URL: https://www.securitycouncilreport.org/atf/cf/\%7B65BFCF9B6D27-4E9C-8CD3-CF6E4FF96FF9\%7D/PCS\%20S\%202004\%20616.pdf [in Eng.]

165. Murphy C. (2020). Religion \& Transitional Justice. Daedalus, MIT Press - Journals, r. № 3, 185-200. DOI: https://doi.org/10.1162/daed a 01811 [in Eng.]

166. Червякова О. В. Проблеми та наслідки визнання Україною юрисдикції міжнародного кримінального суду. Теоретичні питання юриспруденції і проблеми правозастосування: виклики XXI століття : тези доп. учасників III Всеукр. наук.-практ. конф. (Харків, 19 черв. 2020 р.); Наук.- дослід. ін-т публ. політики і соц. наук. Харків: НДІ ППСН, 2020. 236 с. С. 227-230. URL: https://pp-ss.pro/wp-

content/uploads/2020/06/\%D0\%A7\%D0\%B5\%D1\%80\%D0\%B2\%D1\%8F\%D0\%B A\%D0\%BE\%D0\%B2\%D0\%B0\%20\%D0\%9E.\%20\%D0\%92..pdf $\quad$ [accessed 19 October 2020]

167. Sopilko, I. N., Medvedieva, M. O., Guliiev, A. G., Bilotsky, S. D., Bukhanevych, O. N., Sirokha, D. I., \& Terekhova, T. A. (2018). International Terrorism and Massmedia. Journal of Legal, Ethical and Regulatory Issues, 21(2), 110. [in Eng.]

168. Sirokha, D., Felyk V., Podorozhnii Y., Podorozhnii A. (2020). Basic aspects of the compliance with discipline and legitimacy within the official activities of police. Amazonia Investiga, 9(25), 487-492. [in Eng.]

169. Protocol Additional to the Geneva Conventions of 12 August 1949, and relating to the Protection of Victims of International Armed Conflicts (Protocol I), 8 June 1977. URL:https://www.icrc.org/en/doc/assets/files/other/icrc_002_0321.pdf [accessed 19 October 2020].

170. International Convention for the Protection of All Persons from Enforced Disappearance. URL: https://www.ohchr.org/en/hrbodies/ced/pages/conventionced.aspx $\quad$ [accessed 19 October 2020].

171. Muñoz M. G., Serralvo J. (2019). International humanitarian law in Colombia: Going a step beyond. Cambridge University Press (CUP). International 
SCIENTIFIC APPROACHES IN JURISPRUDENCE

Review of the Red Cross. Volume 912, 1117-1147. URL:

https://www.cambridge.org/core/journals/international-review-of-the-red-

cross/article/international-humanitarian-law-in-colombia-going-a-step-

beyond/4A4D4C6410CDFFC9D2903C997F2E032B [accessed 19 October 2020].

DOI: https://doi.org/10.1017/s1816383120000181

172. Getman A. P., Yakoviyk I. V. (2019). National Security Strategy of Ukraine: History of Belated Reforms. Problems of Legality, 147, 8. URL:http://plaw.nlu.edu.ua/article/view/186338 [accessed 19 October 2020]. DOI: https://doi.org/10.21564/2414-990x [in Eng.]

173. Іншин, M. І., Сіроха, Д. І. (2015). Соціальний захист в Україні: сутність, проблеми та перспективи. Актуальні проблеми соціального права: науково-практичний посібник. Випуск II, 14. [in Ukr.]

174. Giraldo M. L., Tobón D. J. (2020) Personal archives and transitional justice in Colombia: the Fonds of Fabiola Lalinde and Mario Agudelo. Informa UK Limited. The International Journal of Human Rights, 1-21. URL: https://www.tandfonline.com/doi/abs/10.1080/13642987.2020.1811691?journalCo de $=\mathbf{f j h r} 20$ [accessed 19

October 2020].DOI: https://doi.org/10.1080/13642987.2020.1811691.

175. Cronin-Furman K., Krystalli R. (2020). The things they carry: Victims' documentation of forced disappearance in Colombia and Sri Lanka. SAGE Publications. European Journal of International Relations.URL: https://journals.sagepub.com/doi/10.1177/1354066120946479 [accessed 19 October 2020]. DOI: https://doi.org/10.1177/1354066120946479

176. The Special Jurisdiction for Peace in Colombia: Recommendations for the Selection of Judges of the Chambers and Divisions of the Tribunal for Peace. URL: http://www.dplf.org/sites/default/files/the_special_jurisdiction_peace_colombia_web $06 \quad 03 \quad 2016$ 0.pdf [accessed 19 October 2020].

177. Guerrero F., Aristizabal L.-L. (2020). Images and Memory: Religiosity and Sacrifice - The Cases of Tierralta, Trujillo and Arenillo in Colombia. International Journal of Transitional Justice. Volume 14. Issue 1, 35-55. URL: 


\section{https://academic.oup.com/ijtj/article-}

abstract/14/1/35/5803882? redirectedFrom=fulltext [accessed 19 October 2020]. DOI: https://doi.org/10.1093/ijti/ijz030

178. Report of the Special Rapporteur on the promotion of truth, justice, reparation and guarantees of non-recurrence (Distr.: General, 21 August 2017, A/HRC/36/50). URL: https://undocs.org/A/HRC/36/50 [accessed 19 October 2020].

179. Additional Protocol (1977) to the Geneva Conventions of 12 August 1949, concerning the protection of victims of international armed conflicts. $<$ https://www.icrc.org/ru/doc/ resources/documents/misc/treaties-additional-protocol1.htm $>$ (accessed on 24/09/2020). [in English].

180. Acte du congrès de Vienne du 9 juin 1815 avec ses annexes. British and foreign state papers. 1815-1816, vol. 3 (compiled by the Librarian and Keeper of the papers, Foreign Office). <https:// books.google.co.uk/books?id $=$ UY8AAAAAYAAJ\& $\quad \mathrm{pg}=\mathrm{PA} 7 \& \mathrm{hl}=\mathrm{ru} \# \mathrm{v}=$ onepage $\& \mathrm{q} \& \mathrm{f}=$ false $>\quad$ (accessed on 24/09/2020). [in English].

181. Agreement on the Cessation of Hostilities in Viet-Nam 20 July 1954 $<$ https://history.state.gov/historicaldocuments/frus1952-54v16/ch8> (accessed on 24/09/2020). [in English].

182. An Agenda for Peace. Preventive diplomacy, peacemaking and peacekeeping. Report of the Secretary-General on 17 June 1992. $<$ https://www.un.org/ruleoflaw/blog/document/an-agenda-for-peace-preventivediplomacy-peacemaking-and-peace-keeping-report-of-the-secretary-general/> (accessed on 24/09/2020). [in English].

183. Antipenko, V., Timchenko, L.. Byeglij, O. (2012) Mizhnarodne publichne pravo: pidruchnik u 3 t. za zag. red. ta in. Kiyiv : NAU. T. 1.

184. Brounli, Ya. (1977). Mezhdunarodnoe pravo: v 2-h kn. Moskva : Progress.

185. Convention Relating to the Régime of the Straits $<$ http://www.mfa.gov.tr/ii_-convention-relating-to-the-regime-of-the-straits.en.mfa $>$ (accessed on 24/09/2020). [in English]. 
SCIENTIFIC APPROACHES IN JURISPRUDENCE

186. Constantinople Convention $\quad$ October $29, \quad 1888$. $<$ https://loveman.sdsu.edu/docs/1888C onstantinopleConventionon.pdf $>$ (accessed on 24/09/2020). [in English].

187. Convention on the demilitarization of the Aland Islands. Paris, 30 March 1856 (translation from the original french text). $<$ http://www.kulturstiftelsen.ax/images/internationellaavtal/engelskaavtal.pdf $>$ (accessed on 24/09/2020). [in English].

188. Klymenko, B. (1963). Demylytaryzatsyia y neitralyzatsyia v mezhdunarodnom prave. Moscow: Yzd-vo Ynstytuta mezhdunarodnikh otnoshenyi [in Russian].

189. Micik, V., Buromenskij, M., Gnatovskij, M. (2018). Mizhnarodne publichne pravo : pidruchnik u 2 t. T. 2. Harkiv : Pravo. S. 340

190. Oppengejm, L. (1950). Mezhdunarodnoe pravo. Tom 2. Vojna. Nejtralitet. Moskva : Izd-vo inostr. lit.

191. Resolution adopted by the Security Council at its 1102nd meeting on 4 March 1964 [on establishment of the UN Peace-keeping Force in Cyprus]. $<$ https://digitallibrary.un.org/record/607947? $1 \mathrm{n}=\mathrm{en}>$ (accessed on 24/09/2020). [in English].

192. Report by Secretary-General on the United Nations operation in Cyprus S/5950 September 10, 1964. <https://digitallibrary.un.org/record/538507> (accessed on 24/09/2020). [in English].

193. Resolution 2506 (2020) Adopted by the Security Council at its 8709th meeting, on 30 January 2020. $<$ https://digitallibrary.un.org/record/3848947> (accessed on 24/09/2020). [in English].

194. Shokin, Yu. V. Mizhnarodno-pravovij zvichaj: problemi teoriyi i praktiki : monografiya. Harkiv : Pravo, 2012. 454 s.

195. Treaty of Accession of Austria, Finland and Sweden (1994). $<\mathrm{https}$ ://eurlex.europa.eu/eli/treaty/acc_1994/act_1/pro_2/sign> (accessed on 24/09/2020). [in English]. 
196. Treaty of Peace with Italy signed at Paris, on 10 February 1947. UNTS, Vol. 49, No. $747<$ https://treaties.un.org/doc/publication/unts/volume\%2049/v49.pdf $>$ (accessed on 24/09/2020). [in English].

197. Treaty of Accession of Austria, Finland and Sweden (1994). $<$ https://eurlex.europa.eu/eli/treaty/acc_1994/act_1/pro_2/sign> (accessed on 24/09/2020). [in English].

198. The Versailles Treaty June 28, 1919: Part XV. $<$ https://avalon.law.yale.edu/imt/partxv.asp $>$. (accessed on 24/09/2020). [in English].

199. Справедливое судебное разбирательство в международном праве: юридический сборник БДИПЧ. ОБСЕ, 2013. URL: https://www.osce.org/files/f/documents/e/e/100894.pdf.

200. Всеобщая декларация прав человека (Принята резолюцией 217 A (III) Генеральной Ассамблеи $\mathrm{OOH}$ от 10 декабря 1948 года). URL: https://www.un.org/ru/documents/decl_conv/declarations/declhr.shtml.

201. Международный пакт о гражданских и политических правах (принят резолюцией 2200 А (XXI) Генеральной Ассамблеи от 16 декабря 1966 года). URL: https://www.un.org/ru/documents/decl_conv/conventions/pactpol.shtml.

202. Замечание общего порядка Комитета по правам человека № 32, CCPR/C/GC/32 (23 августа 2007 г) «Статья 14: Равенство перед судами и трибуналами и право каждого на справедливое судебное разбирательство». URL: http://hrlibrary.umn.edu/russian/gencomm/Rhrcom32.html.

203. Міжнародне публічне право. Міжнародний захист прав людини: посібник для підготовки до ЗНО / за заг. ред. Т. Л. Сироїд. Харків: ФОП Бровін O.B., 2018. 292 c.

204. Подборка решений Комитета по правам человека в соответствии с факультативным протоколом. Том 7 (Шестьдесят шестая-семьдесят четвертая сессии (июль 1999 года - март 2002 года). URL: https://www.ohchr.org/Documents/Publications/SDecisionsVol7ru.pdf.

205. Справа «Олександр Волков проти України» (Заява № 21722/11). URL: https://zakon.rada.gov.ua/laws/show/974_947\#Text. 
206. The Constitution of Ukraine. // VVR - 1996. - № 30. - St. 141.

207. Law of Ukraine «On the Judiciary and the Status of Judges».// VVR - 2010 - $\quad$ № 41-42, № 43, № 44-45 - St. 529.

208. Law of Ukraine «On Enforcement Proceedings».// VVR - 2016 - № 30 - St. 542.

209. Law of Ukraine «On bodies and persons who carry out enforcement of court decisions and decisions of other bodies».// VVR-2016 - № 29 - St. 535.

210. Law of Ukraine «On Amendments to the Laws of Ukraine» On State Enforcement Service» and «On Enforcement Proceedings». // BBP - 2005 - № 33 - St. 431.

211. Bilousov YV Enforcement. Textbook -K., 2005.

212. Komarov VV, Sibilov DM, Guze KAetc. Training manual on the subject «Executive Proceedings».// Compiled by: VV Komarov, DM Sibilov, KA Guze and others. - H.: Nat. jurid. acad. Of Ukraine, 2010.

213. The Constitution of Ukraine. URL: http://zakon1.rada.gov.ua/cgibin/laws/main.cgi?nreg=254\%EA\%2F96-\%E2\%F0. (appeal date June 7, 2020)

214. Criminal Code of Ukraine of April 5, 2001 № 2341-III URL: http://zakon1.rada.gov.ua/cgi-bin/laws/main.cgi?nreg=2341-14 (appeal date 09.06 2020)

215. Criminal Procedure Code of Ukraine of April 13, 2012 № 4651-VI URL: http://zakon5.rada.gov.ua/laws/show/4651-17 (appeal date June 9, 2020)

216. «About Advocacy and Advocacy action»: Law of Ukraine of 05.07.2012 № 5076-VI URL: https://zakon.rada.gov.ua/laws/show/5076-17\#Text (appeal date 09. 06. 2020)

217. About prevention of corruption: Law of Ukraine of 14.10.2014 p. № 1700VII URL: http://zakon3.rada.gov.ua/laws/show/1700-18 (appeal date 09. 06. 2020)

218. About operative-search action: the Law of Ukraine from 18.02.1992 № 2135-XII URL: https://zakon.rada.gov.ua/laws/show/2135-12\#Text (appeal date 09. 06. 2020) 
219. Ablamsky S. Processual status of the defender under the CPC of Ukraine: problems of regulation and ways to improve them. Journal "ScienceRise: Juridical Science” 2018. №1 (3). Pp. 49 - 54

220. Voynarovych A. Features of the interrogation of a lawyer as a witness in criminal proceedings. Scientific Bulletin of the International Humanities University Ser .. Jurisprudence. 2015. №18 Book 5. pp. 137-140

221. Zaborovsky VV Legal status of a lawyer in terms of becoming an independent bar of Ukraine: a monograph. Uzhhorod: Helvetica Publishing House, 2017. $900 \mathrm{p}$.

222. Zaborovsky V., Buletsa S., Manzyuk V.: Indemnity of a lawyer as one of the main guarantees of advocacy. Comparative and analytical law. 2016. №4. Pp. 284 $-288$

223. Zaborovsky V. Legal status of a lawyer in terms of the formation of civil society and the rule of law in Ukraine: dis. Dr. jurid. Science. Kyiv, 2017. 577 p.

224. Zaborovsky V. Lawyer as a subject of professional legal (legal) assistance. Comparative and analytical law. 2016. №2. Pp. 248 - 250

225. Karpova N. Yu. Crimes against justice, which are associated with the restriction of the right of a person to protection: dis. Cand. jurid. Science. Kyiv, 2018. $369 \mathrm{p}$

226. Manifesto of protection of lawyers' rights. URL: https://www.uaa.org.ua/novyny/novyny-aau/manifest-zahistu-prav-advokativ/

227. Between a hammer and an anvil: attacks on lawyers in Ukraine / ICJ Mission Report in Ukraine. International Commission of Jurists. Switzerland. 2019. 66 p.

228. Review of the case law of the Criminal Court of Cassation of the Supreme Court on ensuring the right to protection in criminal proceedings (cases) / Order: Legal Department (III) of the Department of Analytical and Legal Work of the Supreme Court. Kyiv, 2019. 36 p. 
SCIENTIFIC APPROACHES IN JURISPRUDENCE

229. Semenov V. Guarantees of advocacy in the pre-trial investigation. URL: http://algiz.legal/garanti\%D1\%97-advokatsko\%D1\%97-diyalnosti-na-dosudovomurozsliduvanni/

230. Svyridenko S. Pre-trial investigation in criminal proceedings against persons who enjoy immunity: dis. cand. jurid. Science. Kyiv, 2018. 232 p.

231. Yukhno O. Features of pre-trial investigation of a particular category of persons: scientific and methodological recommendations. KhNUVS, 2017. 60 p.

232. Кримінальний процесуальний кодекс України в редакції від 11.09.2020 року / електронний pecypc https://zakon.rada.gov.ua/laws/show/465117/conv\#n3930;

233. Кримінальний кодекс України в редакції від 14.11.2020 / електронний ресурс https://zakon.rada.gov.ua/laws/show/2341-14\#Text;

234. Конвенція про права дитини / електронний ресурс https://zakon.rada.gov.ua/laws/show/995 021\#Text;

235. Постанова пленуму Верховного Суду України «Про практику розгляду судами справ про застосування примусових заходів виховного характеру» / електронний ресурс https://zakon.rada.gov.ua/laws/show/v000270006\#Text;

236. Лист Вищого спеціалізованого суду України з розгляду цивільних i кримінальних справ від 16.01.2017 № 223-66/0/4-17 «Про практику здійснення судами кримінального провадження щодо неповнолітніх» / електронний ресурс https://zib.com.ua/ua/print/127476-list_vssu_vid_16012017_223-6604-

17 pro_praktiku_zdiysnennya_html ;

237. Карелін Д.В. «Примусові заходи виховного характеру як альтернатива кримінальної відповідальності».

238. Волков Л. В. Казенная палата // Государственность России (конеи ХУ в. - февраль 1917 г.): Словарь-справочник. М. : Наука, 1999. С. 153-158.

239.Головко О. М. Фінансова адміністрачія Російської імперії в Україні (кінець XVIII-початок XX cm.). X. : CIM, 2005. 448 c. 
240.Грамота на права и выгоды городам Российской империи. 1785. Апреля 21 // ПСЗ. Собрание первое. СПб. : тип. II Отделения собственной Е. И. В. канцелярии, 1830. Т. ХХІІ. №16 188. С. 358-384.

241.Григорьев В.Г. Реформа местного управления при Екатерине II (Учреждение о губерниях 1775 г.). СПб. : „Русская скоропечатня”, 1910. 387 с.

242.Лысенко Л. М. Губернаторы и генерал-губернаторы Российской империи (XV-начало ХХ века). М. : изд-во МПГУ, 2001. 358 с.

243.Мулов П. Историческое обозрение мер к устройству городского общественного управления. СПб. : тип. М-ва внутренних дел, 1864. 198 с.

$244 . О$ дворянских выборах в уездные места и губернские предводители // ПСЗ. Собрание первое. - СПб. : тип. ІІ Отделения собственной Е. И. В. канцелярии, 1830. - Т. XXV - №19 154. - С.812.

245.0 собрании с дворянских имений особых сумм на содержание по губерниях судебных мест // ПСЗ. Собрание первое. СПб. : тип. II Отделения собственной Е. И. В. канцелярии, 1830. Т. XXIV. №18 278. С. 846-850.

246.Учеждение для управления губерний Всероссийской империи. 1775. Ноября 7 // ПСЗ. Собрание первое. СПб. : тип. II Отделения собственной Е. И. В. канцелярии, 1830. Т. ХХ. №14 392. С. 229-304.

247.Шандра В. С. Совісні суди в Україні (остання чверть XVIII - середина $X I X$ cm.) К. : Інститут історії України НАН України, 2011. 266 с.

248.Шандра В.С. Справник // Енщиклопедія історї України / [голова редакиійної колегії В. А. Смолій]. Т.9. К. : Наукова думка, 2012. С. 774-775.

249.Штаты губерний. 1796. Декабря 31 // ПСЗ. Собрание первое. СПб. : тип. II Отделения собственной Е. И. В. канцелярии, 1830. Т. XXIV. №17 702. С.269.

250. Гесиод// Антология мировой философии: Методический сборник философских текстов. Т. 1. Ч. 1/ Сост. М. А. Парнюк, В. И. Даниленко. - К.: УМК BO, 1991. - С. 52-53.

251. Там саме.

252. Гераклит// Таранов П. С. Анатомия мудрости: 120 философов: в 2-х т./ П. С. Таранов. - Симферополь: Реноме, 1997. - Т. 1. - С. 122-129. 
253. Парменид// Антология мировой философии: Методический сборник философских текстов. Т. 1. Ч. 1/ Сост. М. А. Парнюк, В. И. Даниленко. - К.: УМК BO, 1991. - C. 59-62.

254. Історія вчень про державу і право: підруч./ За ред. проф. Г. Г. Деміденка і проф. О. В. Петришина. - Х.: Право, 2007. - 390 с.

255. Ц Ціцерон, Марк Тулін. Про державу; Про закони; Про природу богів/ Пер. $з$ латин. Володимира Литвинова. - К.: Основа, 1998. - 476 с.

256. Там саме.

257. Протагор// Антология мировой философии: Методический сборник философских текстов/ Сост. М. А. Парнюк, В. И. Даниленко. - К.: УМК ВО, 1991. - C. 66-67.

258. Там саме.

259. Там саме.

260. Там саме.

261. Там саме.

262. Платон. Апология Сократа, Критон, Ион, Протагор/[Общ. ред. А. Ф. Лосева и др.]; Авт. вступит. статьи А. Ф. Лосев; примеч. А. А. Тахо-Годи; пер. с древнегреч. - М.: Мысль, 1999. - 864 с.

263. Рагозин Н. П. Происхождение и развитие идеи прав человека// Права человека в современном мире. - Донецк: Донецкая школа прав человека, 1995. C. $4-22$.

264. Платон. Апология Сократа, Критон, Ион, Протагор/[Общ. ред. А. Ф. Лосева и др.]; Авт. вступит. статьи А. Ф. Лосев; примеч. А. А. Тахо-Годи; пер. с древнегреч. - М.: Мысль, 1999. - 864 с.

265. Себайн Джордж Г., Торсон Т. Л. Історія політичної думки/ Пер. 3 англ./ - К.: Основи, 1997. - 838 с.

266. Поппер К. Відкрите суспільство та його вороги. Том 2/Перекл. $з$ англ. О. Буценка. - К.: Основи, 1994. - 494 с.

267. Аристотель. Сочинения в четырех томах. Т.1/Ред. В. Ф. Асмус. - М.: Мысль, 1976. - 550 с. 
268. Там саме.

269. Аристотель. Никомахова этика//Аристотель. Сочинения в 4-х томах. - Т. 4. - М.: Мысль, 1983. - 832 с.

270. Аристотель. Политика// Сочинения в 4-х томах. - Т.4 - М.: Мысль, 1983. $-832 \mathrm{c}$.

271. Себайн Джордж Г., Торсон Томас Л. Історія політичної думки/Пер. 3 англ. - К.: Основа, 1997. - 838 с.

272. Там саме.

273. Аристотель. Никомахова этика// Аристотель. Сочинения в 4-х томах. - Т. 4. - М.: Мысль, 1983. - 832 с.

274. Арістотель. Політика/ Пер. $з$ давньогр. та передм. О. Кислюка. - К.: Основи, 2000. - 239 с.

275. Там саме.

276. Муляр В. І. Проблема становлення особистості в системі «індивід суспільство»/ філософсько-культурологічний аналіз - Житомир: ЖДТУ, 2005. $320 \mathrm{c}$.

277. Баткин Л. М. Итальянское Возрождение в поисках индивидуальности. - М.: Наука, 1989. - 270 с.

278. Себайн Джордж Г., Торсон Томас Л. Історія політичної думки/Пер. 3 англ. - К.: Основи, 1997. - 838 с.

279. Там саме.

280. Гроций Г. О праве войны и мира. Три книги, в которых объясняется естественное право и право народов, а также принципы публичного права/ Пер. с. лат. А. Л. Сакетти под ред. С. Б. Крылова. - М.: Гос. Изд-во юр. Лит-ры, 1957. $-868 \mathrm{c}$.

281. Себайн Джордж Г., Торсон Томас Л. Історія політичної думки/Пер. 3 англ. - К.: Основи, 1997. - 838 с.

282. Там саме.

283. Там саме. 